Historic, Archive Document

Do not assume content reflects current scientific knowledge, policies, or practices. 



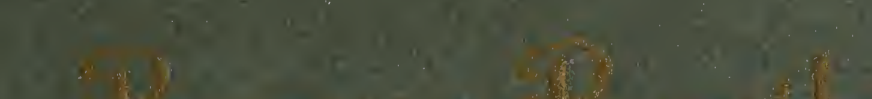
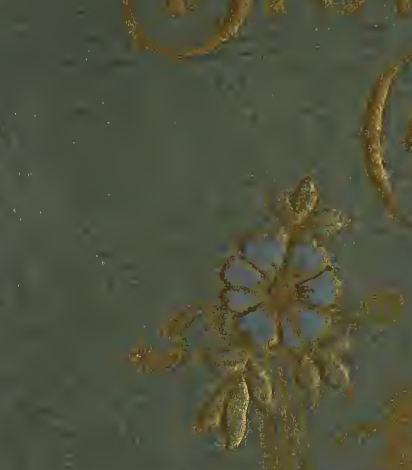
(a)

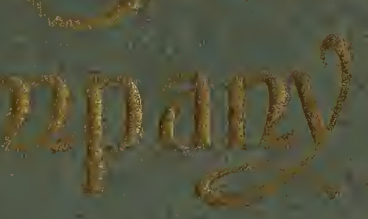

i:

(9)

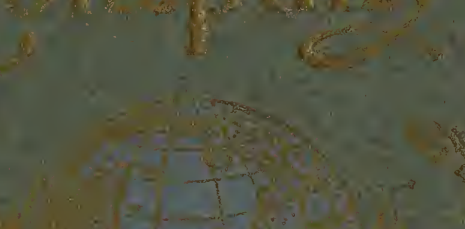

(f)

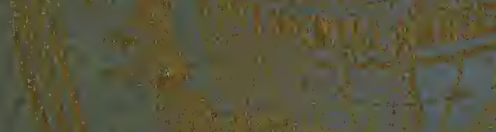

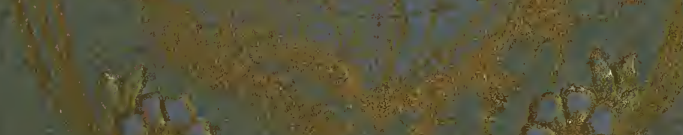

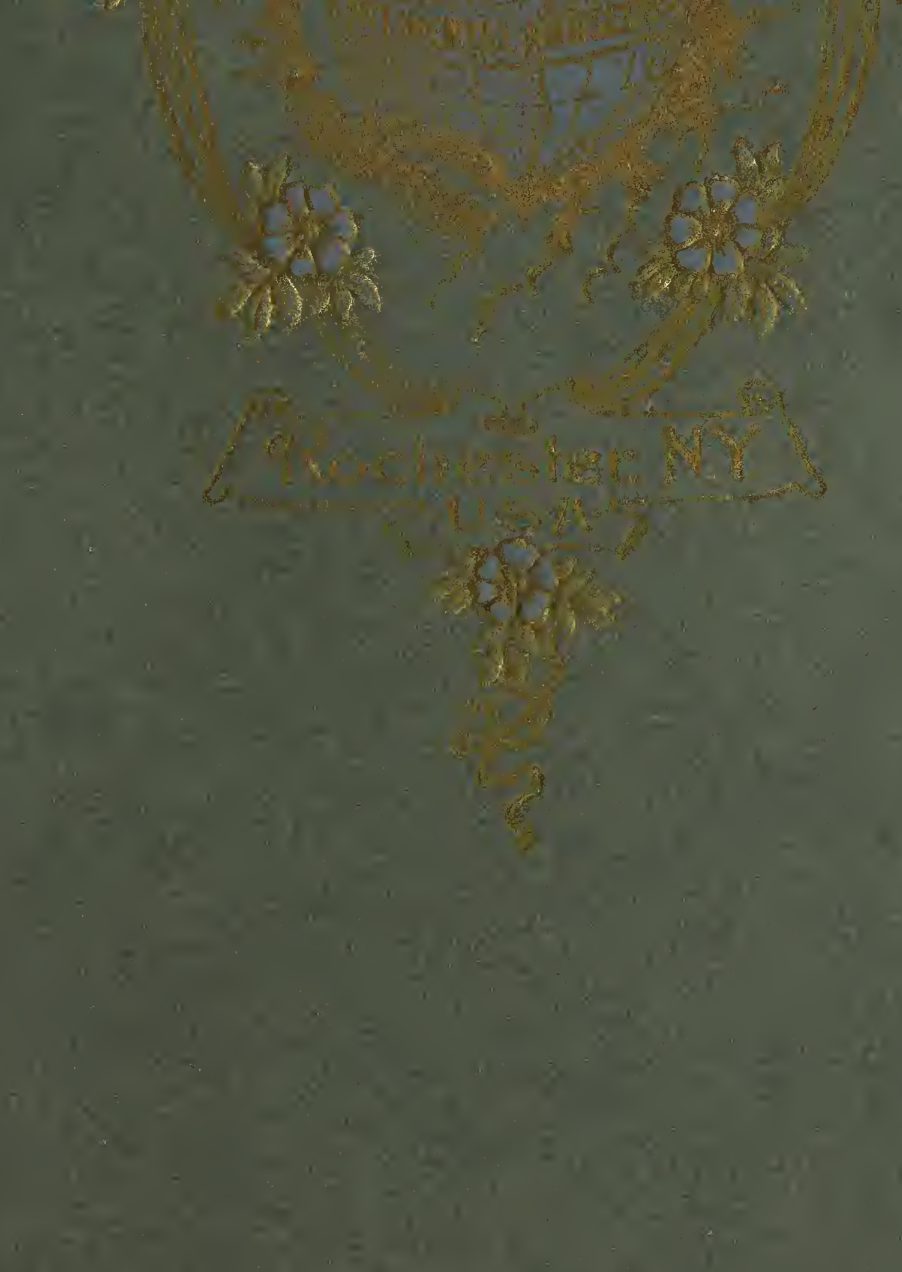

(x) 


\section{Descriptive Catalog}

\section{Jjuit}

and Ormamental

\section{Treps}

EVERGREENS, SHRUBS PERENNIAL PLANTS

ROSES, ETC.

G R O W N A N D FOR S A L E B Y BROWN BROTHERS

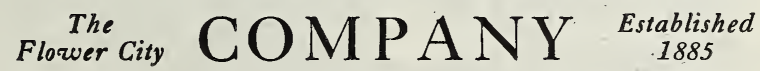
Continental Nurseries :: ROCHESTER, N. Y. 


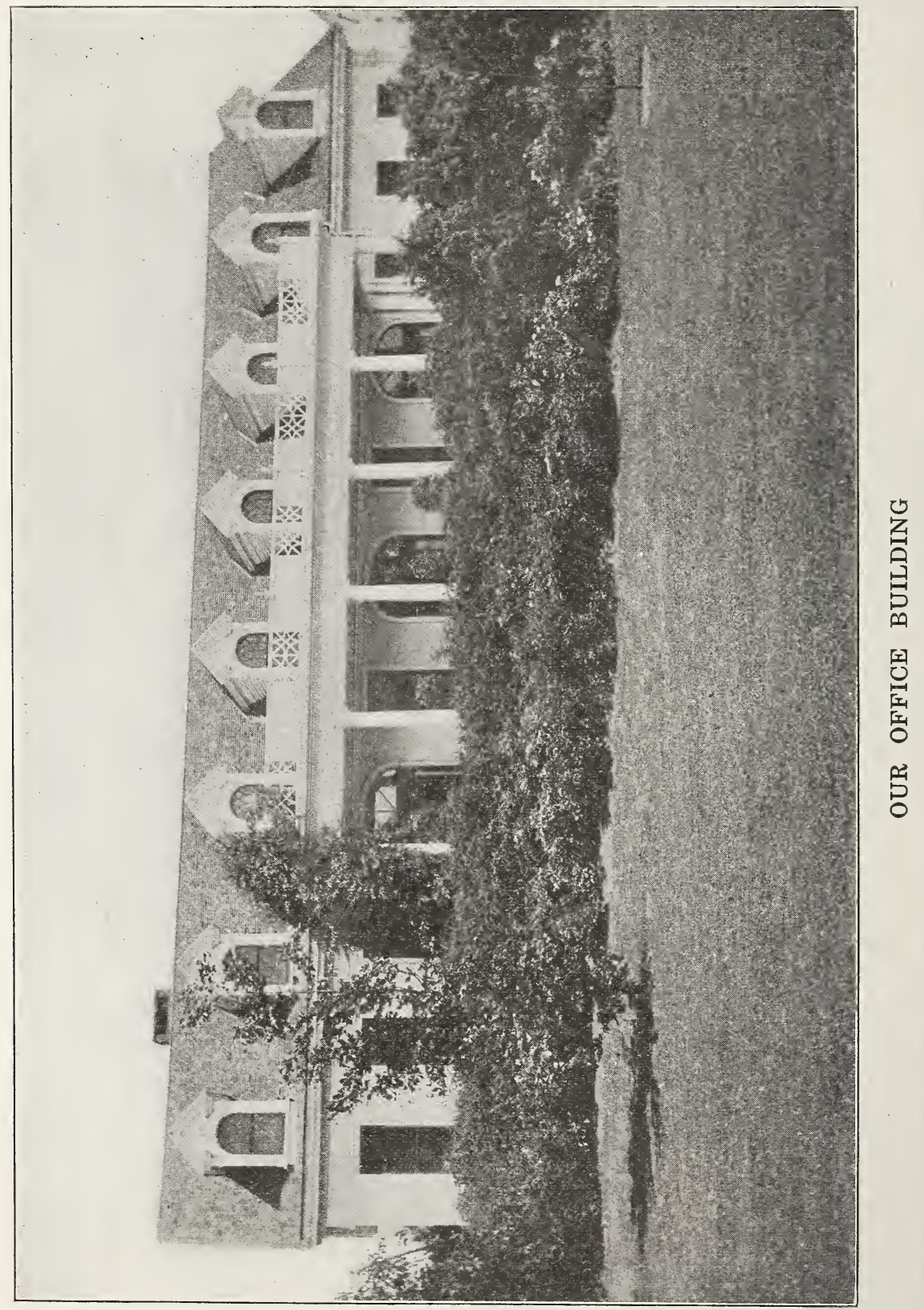




\section{N T R O D U G T I O N}

$W^{\mathrm{n}}$

$\mathrm{E}$ take pleasure in presenting herewith our revised catalog, which you will find complete and reliable, and assure our representatives and customers that in the future we will pursue the same careful business policy as has been our custom for many years, and which is responsible for our present position in the nursery business, ranking as we do among the several largest concerns in the Country.

We have added descriptions of desirable new trees, shrubs and plants and have omitted such items as experience and progress in horticulture and floriculture have proven no longer worthy of general dissemination. With our 1200 acres of nurseries and our exceptional storage and shipping facilities, we are able to fill orders promptly and with satisfaction.

Nurseries.-Our office is loc at ed at Browncroft, a beautiful residential development in the Eastern part of the City. While we have several hundred acres of planting just East of BROWNCROFT, partly in the City of Rochester and partly in the Town of Brighton, N. Y., we also have nurseries at Irondequoit, Webster and Penfield, N. Y.

Fruit Farms.-During the past few years we have planted two farms of four hundred acres to Peaches, Apples, Standard Pears, Cherries, Plums and Prunes, now having 45,000 trees in bearing. These orchards rank among the largest in the State and enable us to propagate fruit trees that are of the best pedigreed quality, that will bear the best fruit for market purposes, and which can be absolutely depended upon.

Ornamental Stock.-While the fruit business is very extensive in a few restricted areas, the planting of ornamental and shade trees, flowering shrubs, roses, perennials, vines, evergreens, etc., is increasing everywhere-there has been a constantly increasing demand for this class of stock, not only in the cities, but in the small villages, and during the past few years even the farmers have been demanding home surroundings equal to the finest anywhere.
The home grounds are beginning to receive the attention they justly deserve.

The men in charge of our nurseries are careful and experienced propagators and cultivators, many of them having been in our employ for the past thirty years. We personally oversee all of our plantings and carefully watch every variety, so that nothing unfit for sale shall be allowed to be put on the market.

Our extensive frost-proof cellars, where the temperature can be maintained at 36 degrees for about half of each year, enablt us to pack all stock under cover, and the trees and plants are never exposed to atmospheric influences from the time they are taken from the ground until they reach the customer in perfect condition for planting. The advantage of this feature can hardly be over-estimated. We cannot only ship earlier than most other companies, but we are able to furnish perfectly dormant stock for many weeks after other nurseries are through shipping, and even after trees standing in the nursery are in full bloom.

Our business is carried on by reliable salesmen, but in such places where we are not represented, we shall be pleased to receive orders direct. 


\title{
LIST OF EXPERIMENTAL STATIONS
}

\begin{abstract}
A LL fruit growers should be familiar with the literature issued by their nearest Experiment Station relating to the culture of fruit trees and the raising of all kinds of fruits. Nearly all of the Stations mentioned below issue bulletins on a large variety of subjects, and, at the present time, are devoting a great deal of attention to the raising of fruit, injurious insects, diseases of fruit trees, spraying, etc. Any resident is entitled to receive the bulletins from his nearest station, free of charge, and all that the applicant has to do is to direct a letter to "The Director," asking information on any subject he may be interested in. If you have an orchard that is not producing the fruit that it should or is infected with some disease, you can get just the information you desire from these Stations. They are always pleased to hear from the residents especially of their own state.
\end{abstract}

Alabama. Agricultural Experiment Station, Auburn; Canebrake Experiment Station, Uniontown; Tuskegee Institute, Tuskegee.

Arizona. Agricultural Experiment Station, Tucson.

Arkansas. Agricultural Experiment Station, Fayetteville.

California. Agricultural Experiment Station, Berkley.

Colorado. Agricultural Experiment Station, Fort Collins.

Connecticut. Agricultural Experiment Station, New Haven; Storrs Agricultural Experiment Station, Storrs, P. O.

Delaware. Agricultural Experiment Station, Newark.

Florida. Agricultural Experiment Station, Lake City.

Georgia. Agricultural Experiment Station, Experiment, $\mathrm{P} . \mathrm{O}$.

Idaho. Agricultural Experiment Station, Mos. cow.

Illinois. Agricultural Experiment Station, Urbana.

Indiana. Agricultural Experiment Station, Lafayette.

Iowa. Agricultural Experiment Station, Ames.

Kansas. Agricultural Experiment Station, Manhattan.

Kentucky. Agricultural Experiment Station, Lexington.

Louisiana. Sugar Experiment Station, New Orleans; State Agricultural Experiment Station, Baton Rouge; North Experiment Station, Calhoun.

Maine. Agricultural Experiment Station, Orono.

Maryland. Agricultural Experiment Station, College Park.

Massachusetts. Agricultural Experiment Station, Amherst.

Michigan. Agricultural Experiment Station, Agricultural College, P. O.

Minnesota. Agricultural Experiment Station, St. Anthony Park.

Mississippi. Agricultural Experiment Station, Agricultural College, P. O.

Missouri. Agricultural Experiment Station, Columbia; Fruit Experiment Station, Mt. Grove.
Montana. Agricultural Experiment Station, Bozeman.

Nebraska. Agricultural Experiment Station, Lincoln.

Nevada. Agricultural Experiment Station, Reno.

New Hampshire. Agricultural Experiment Station, Durham.

New Jersey. State Experiment Station, New Brunswick.

New Mexico. Agricultural Experiment Station, Messila Park.

New York. Agricultural Experiment Station, Geneva; Cornell Agricultural Experiment Station, Ithaca.

North Carolina. Agricultural Experiment Station, Raleigh.

North Dakota. Agricultural Experiment Station, Fargo.

Ohio. Agricultural Experiment Station, Wooster.

Oklahoma. Agricultural Experiment Station, Stillwater.

Oregon. Agricultural Experiment Station, Corvallis.

Pennsylvania. Agricultural Experiment Station, State College P. O.

Rhode Island. Agricultural Experiment Station, Kingston.

South Carolina. Agricultural Experiment Station, Clemson College P. O.

South Dakota. Agricultural Experiment Station, Brookings.

Tennessee. Agricultural Experiment Station, Knoxville.

Texas. Agricultural Experiment Station, College Station P. O.

Utah. Agricultural Experiment Station, Logan.

Vermont. Agricultural Experiment Station: Burlington.

Virginia. Agricultural Experiment Station Blacksburg.

Washington. Agricultural Experiment station, Pullman.

West Virginia. Agricultural Experiment Station, Morgantown.

Wisconsin. Agricultural Experiment Station, Madison.

Wyoming. Agricultural Experiment Station, Laramie. 


\section{Transplanting Directions}

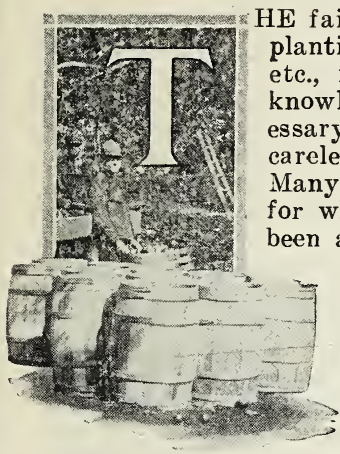

$\mathrm{E}$ failures experienced in the lanting of Trees, Shrubs, result from a want of e conditions necssary to success, or from a careless disregard of them. Many Nurserymen are blamed for what might easily have been avoided had the planter consulted the plain wants and requirements of the stock and given it at least a fair ehance to grow and do well. We are interested in the success of every article we send out; we take the greatest pains to place every item in the hands of our customers in the best possible condition, and in order to furnish some precautions which our experience suggests, and urge to a more cautious and considerate culture, we give a few hints on such points as are most essential.
How to Take Care of Trees on Arrival

If not ready to plant on arrival, unpack the trees, but do not leave the roots exposed to freezing temperature. Dig a trench in some high and dry ground and heel in, covering the roots with earth and follow directly with plenty of water around the tree. You can leave them in the trenches until you are ready to set out. If frozen on arrival, leave in the boxes and place in cellar or in a cool, dark room that is free from frost, and let them remain until the frost has disappeared. If no cellar cover with sawdust or bury in sandy soil until frost has gone. Do not expose frozen trees to heat, light or air. Trees frozen solid will not be injured if handled in this way. If too dry from exposure or transit, bury in earth or place in water from 10 to 20 hours.

\section{How to Prepare the Soil}

The soil should be dry for fruit trees, either natural or by drainage. They will not thrive on damp ground. The land should be plowed two or three times and worked well with spring

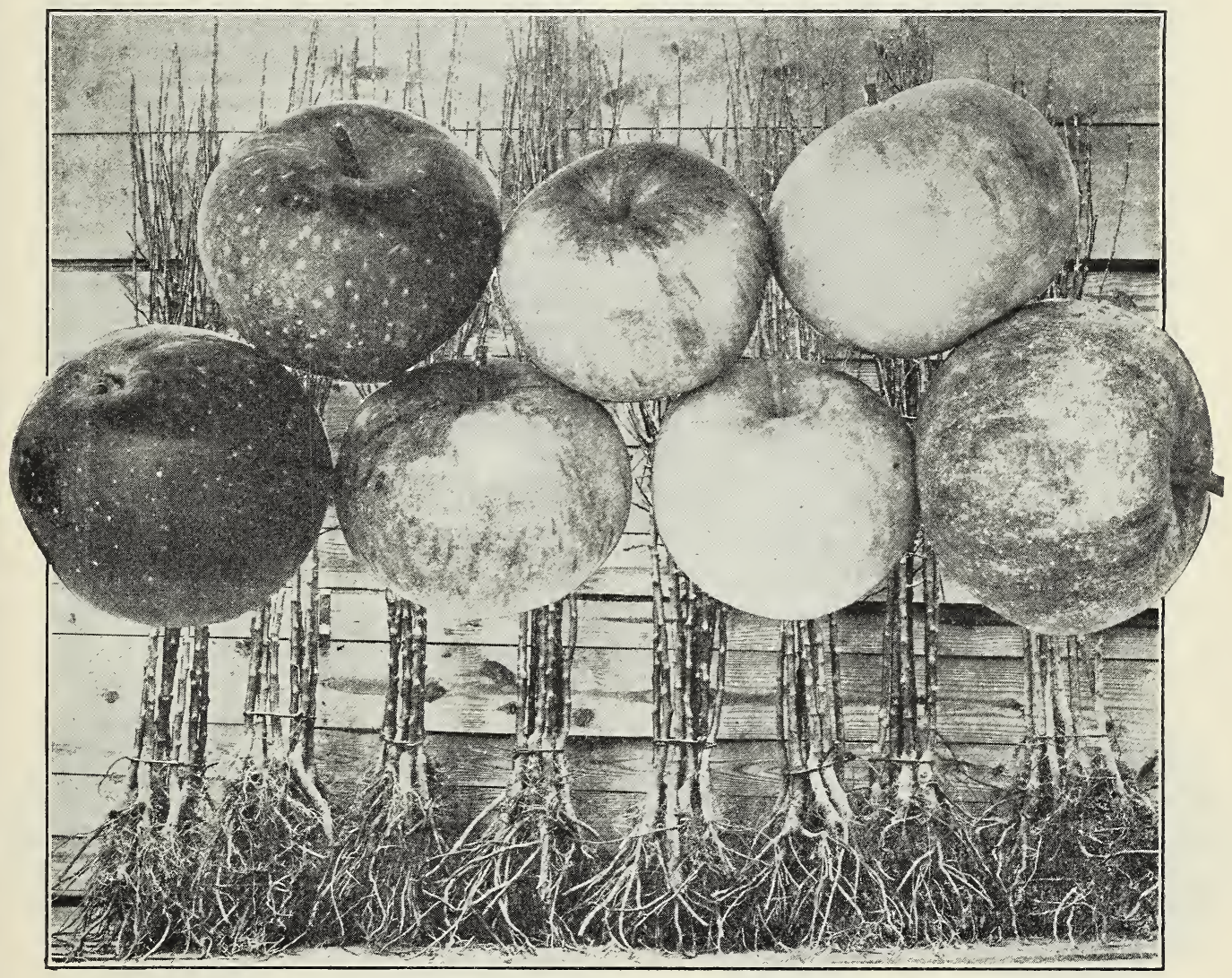

Well Rooted Trees Produce Well Fruited Trees 
tooth drag or pulverizer previously to the planting. New land needs no manure, but if you wish to set an orchard on land having green crops, it is a good plan to fertilize either with plenty of barnyard manure or turn under a growth of clover. Give the land as good a preparation as for wheat, corn or potatoes and your trees will show rapid growth, and will fruit earlier.

Standard Trees. They vary from five to seven feet in height, with naked stems or trunks, and a number of branches at the top forming a head. These branches should all be cut back to within three or four buds of their base. This lessens the demand upon the roots, and enables the remaining buds to push with vigor. Cut off smoothly all bruised or broken roots up to the sound wood.

Pruning, after the first year, should be varied according to the purpose of the planter, and the variety of the trees. They should be trimmed as early as possible up to the height it is intended the future head should be, that the cutting off of large limbs may not in the future be necessary. After the removal of the lower branches till the head has reached the desired height, the only pruning needed is to remove such branches as are crossing or interfering with each other, and to keep the head in symmetrical shape and open to sun and air. Trees should receive proper shape by

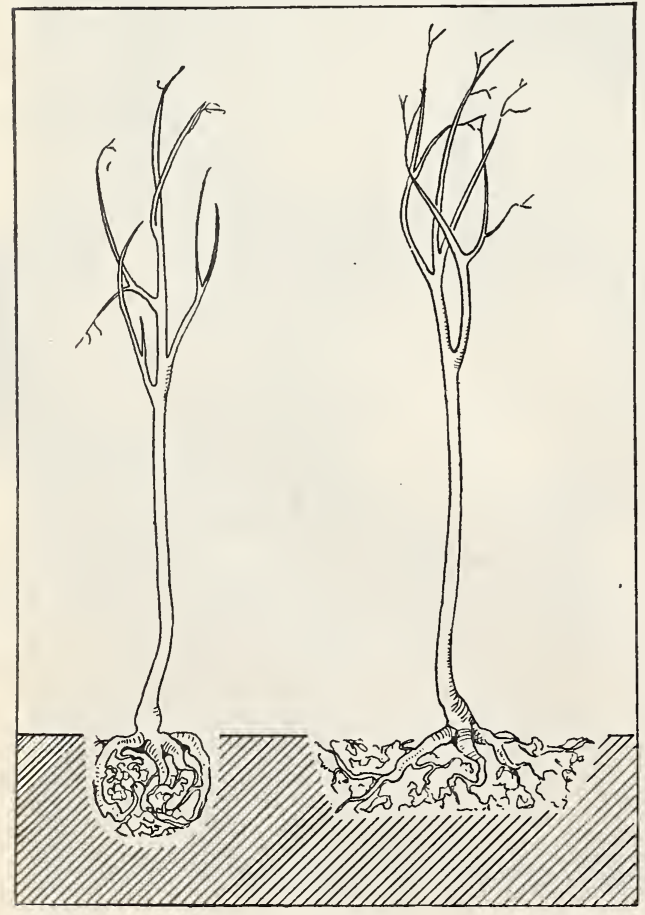

Wrong Way

Right Way pruning early in the spring of each year, while they are young, and very little pruning will be needed afterwards.

Dig holes large enough to admit the roots of the tree to spread out in their natural position; then, having the tree pruned as before directed, let one person hold it in an upright position, and the other shovel in the earth, carefully putting the finest and the best from the surface in among the roots, bringing every root in contact with the soil. When the earth is nearly filled in, a pail of water may be thrown around the roots; then fill in the remainder and tread gently with the foot. The use of water is seldom necessary, except in dry weather early in fall or late in spring. Guard against planting too deep; the trees, after the ground settles, should stand in this respect as they did in the nursery. Trees on dwarf stock should stand so that all the stock be under the ground, and no more. In very dry, gravelly ground, the holes should be dug twice the usual size and depth, and filled in with good loamy soil. Keep grass and weeds away from trees.

Dwarf Trees, if two or three years growth, with a number of side branches, will require pruning. The branches must be cut into the form of a pyramid by shortening the lower ones, say one-half, those above them shorter, and the upper ones around the leading shoots to within two or three buds of their base. The leader itself must be shortened back one-half or more. When trees have been dried or injured much by exposure, the pruning must be closer than if in good order.

Staking. If trees are tall or in exposed situations, they should be supported by stakes to prevent injury from wind. Staking is done in the best manner by driving two strong stakes firmly in the ground, one on each side of the tree, about a foot from it, and fastening the tree between them with bands of straw or other soft material.

Mulching. This is properly done by placing a layer of coarse manure or litter, from three to six inches deep, about the tree, extending one or two feet further in each direction than the roots. This keeps the ground moist and of an even temperature; renders watering unnecessary, and is in all respects preferable. Trees properly mulched are more certain to live and also make better growth than those not so treated.

Cultivation after Planting. Many cultivators after going to great trouble and expense in selecting and planting trees, fail by neglecting that after-care and attention that is equally essential. Caterpillars and Canker Worms, Grubs and Borers, Slugs and Aphis, Disease and Blight must be watched for, and remedies faithfully applied. The wants of the trees must be foreseen and a faithful effort made to ensure health and productiveness. For such care the cultivator will be well repaid with thrifty, shapely trees and abundant crops 
of superior fruit. His neighbor, with perhaps better soil and advantages at the outset, and equal care and experience in planting, having neglected these apparently trivial, but really important matters, sees instead of thrifty trees loaded with luscious fruit, a few mossy, scraggy specimens.

Those who are obliged to plant trees in fields of grain and grass, should see that all such are carefully mulched with coarse manure, and that the ground is kept loose and moist about the tree. A hoed crop is preferable in such plantations for the first five years. After this time, Standard Apple, Pear and Plum Trees will grow and produce fairly in turf. The Dwarf Trees and leaches should be well mulched every year with coarse manure, and the ground thoroughly cultivated.

Grape Vines. Require a dry, mellow, welldrained soil, deeply worked and well enriched, with a warm, sunny exposure. In planting give the roots plenty of room and settle the soil firmly about them. A strong vine may be allowed to grow the first season without pruning; in November or December following, the growth should be cut back to three or four buds; the next season allow but two buds to grow, which should make canes seven to ten feet long and be cut back to four or five feet, ready for fastening to the trellis. Finer grapes and larger crops will be secured where there is not an excess of vine. For the subsequent pruning of vines, as well as trees, planters would do well to consult some practical works on the subject.

Berries. Should have strong soil and be kept under constant cultivation. Mulching is of special value. Raspberries and Blackberries should have the old canes cut out each year, and new canes pinched off when three feet high. If the position is at all exposed, it is well to raise a mound between the hills late in the fall, bend the canes over this mound and peg them down during the winter. Straw. berries should be mulched late in the fall; uncover the crowns early in the spring, remove the mulch after fruiting and spade in light dressing of manure. If set for fruit, keep the runners cut off.

Currants and Gooseberries should be mulched every spring and well pruned, so that new wood may have a chance to grow. The ground about them should be kept in good condition by manure and cultivation. The worms may be destroyed with certainty by applying White Hellebore powder shaken from a coarse bag as soon as they appear, and repeating the operation once or twice.

Roses. Nothing repays good care better than Roses. They should have a deep, rich, vell-drained soil, thorough cultivation and plenty of manure. They should be pruned every spring before the buds swell, cutting back all the last year's growth to three or four buds, excepting Climbing or Pillar Roses, which may first be allowed partly to cover space desired, old decayed branches should never remain. Climbing, Moss and Hybrid Perpetual sorts require no protection, but the so-called "tender" varieties should be covered with leaves. straw or branches of evergreens, late in the fall. If the "thrip" or fly appears it may be disposed of by applying decoctions of tobacco steeped in water. Every autumn, com. post should be placed around the stems of the plants and spaded into the ground the follow. ing spring.

Budded roses should be planted deep in the ground so that the bud is slightly covered with earth. and then during the growing season should be carefully watched and every shoot or sucker that grows from the wild root below the bud, should be cut off as soon as it makes its appearance. If this is done the budded shoot or stock receives the full strength of the plant and grows rapidly and blooms freely. If it is not done and the wild shoots or suck. ers are allowed to grow, they take all the strength of the roots and in a short time the budded shoot dies and nothing is left but the wild shoots from the roots which, of course, bear nothing but ordinary wild roses.

Fruit Growing is a much better line of farm work than raising grain. There is no question about the result. The demand for apples, peaches, pears and cherries is greater to-day than ever, and it will continue as long as the earth bears. Fruit is one of the best foods, besides it comes to us pure and healthful and will always demand a good price.

Every person owning land from a back yard to a 300 -acre farm should plant fruit. Plant at the earliest possible time.

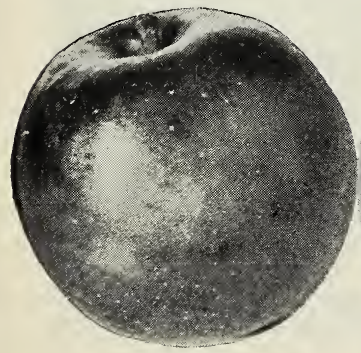

Jonathan

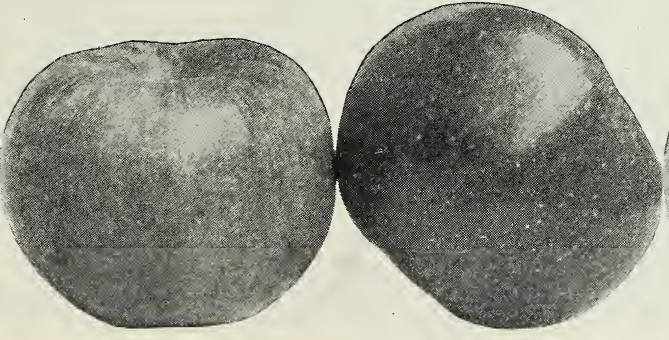

Stayman's Winesap

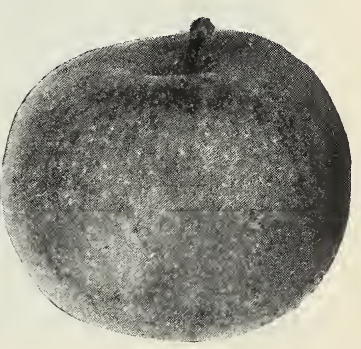

King 


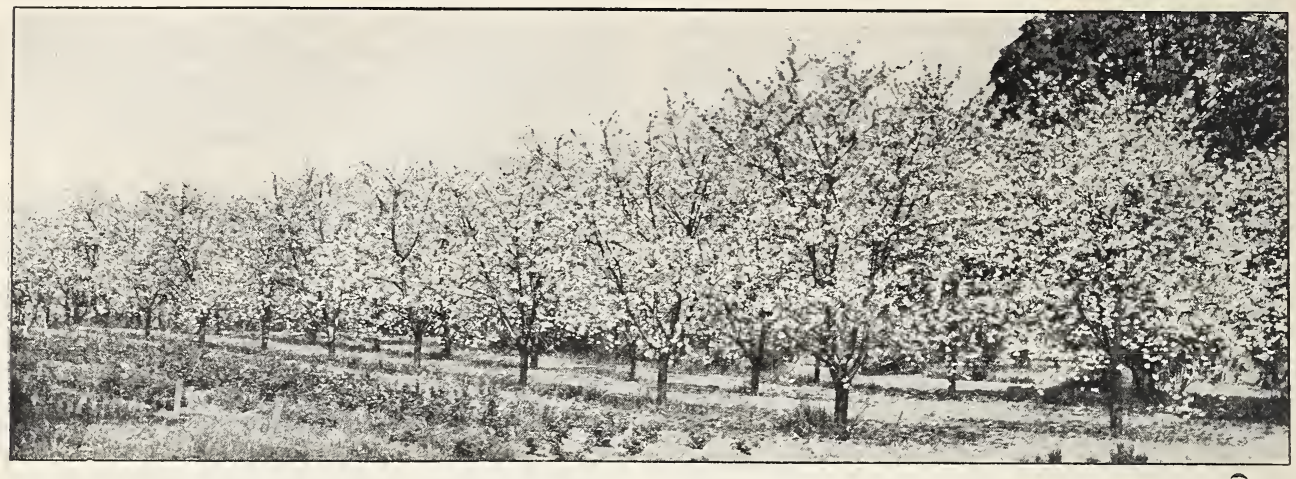

\section{Age of Trees and Plants We Sell}

Standard Apple, 3 and 4 years.

Crab Apples, 2 and 3

Dwarf Pears, 2 and 3

Plums. 2 and 3

Gooseberries and

Currants, 1 and 2

Rasp. and Blackberries, 2

Shrubs, 1, 2 and 3 years, according to kind.

Dwarf Apples, 2 and 3 years.

Standard Pears, 3

Cherries, 2 and 3

Peach, 1 and 2

Qpince, 2

Grapes, 2

Roses, 1 and 2

Asparagus, 1 and 2

\section{Size of Ornamental Trees}

Cut-Leaved Weeping Birch, 4 to 6 feet.

Chestnut (American Sweet), 5 to 7

Horse Chestnut, 5 to 7

Linden, 6 to 8

Mountain Ash, 6 to 8

Cut-Leaved Alder, 4 to 6 feet.

Elm, 6 to 8

Larch, 2 to 4

Maple, 6 to 8

Oak-Leaved, 4 to 6

\section{Number of Trees or Plants to Acre}

2 feet each way.10,890

3 feet each way. 4,840

4 feet each way. 2,723

5 feet each way. 1,742

6 feet each way. 1,210

8 feet each way. 681

10 feet each way. 430

2 feet each way. 302

15 feet each way...194

18 feet each way...135

20 feet each way...110

25 feet each way... 70

30 feet each way....4 48

33 feet each way... 40

40 feet each way.... 28

To estimate the number of plants required for an acre, at any given distance, multiply the distance between the rows by the distance between the plants, which will give the number of square feet allotted to each plant, and divide the number of square feet in an acre $(43,560)$ by this number, the quotient will be the number of plants required.

\section{Distance for Planting}

Apples, Std....30.40 ft. Apples, Dwarf . 8-10 ft.

Grapes ..... $8 \times 10 \mathrm{ft}$. Currants $\cdots \cdots 3 \times 5 \times 3 \mathrm{ft}$. Gooseberries ...3 $5 \mathrm{ft}$. Raspberries, Red.3x $6 \mathrm{ft}$. Raspberries, Blk.3x $6 \mathrm{ft}$. Blackberries ‥5x $7 \mathrm{ft}$. Strawberries, rows $1 \times 4 \mathrm{ft}$. Strawberries, in

beds ..... $11 / 2 \times 11 \frac{1}{2} \mathrm{ft}$. Aspar. in bds. . $1 \times 1 \frac{1}{2} \mathrm{ft}$. Asparagus in field.1x3 $\mathrm{ft}$.

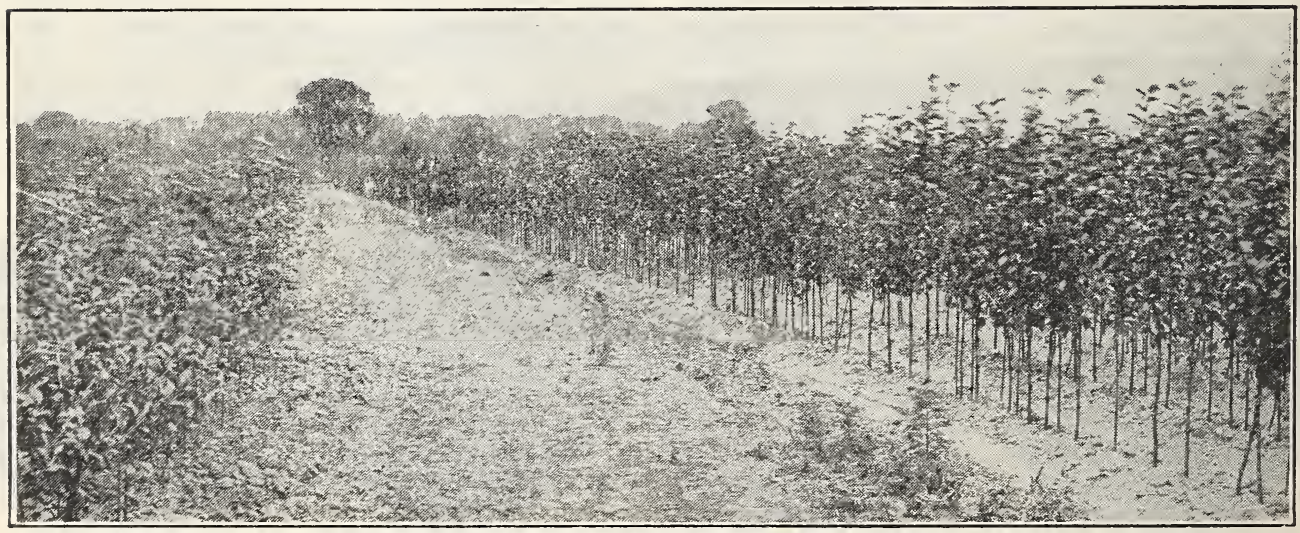

Block of 100,000 Apple Trees 


\section{Age at which Different Trees Fruit}

This varies greatly with different varieties, for instance the "Tetofsky" and "Duchess" standard pears often fruit the second year after transplanting, and bear very regularly, while the "Northern Spy" seldom fruits in less than seven years after transplanting, though one of the best apples and a prolific bearer when of fruiting age. The average time it takes for standard apples to fruit is four or five years.

Dwarf Apples, 2 years. Blackberries, 2 years. St. Pears, 3 to 4 " Cherries, 3 to 4 " Gooseberries, 2 Grapes, 2

Quinces, 3 to 4

Roses generally bloom the season of planting.

\section{Formulas for Spraying}

\section{Arsenite of Lead}

Arsenite of Lead, 4 to 6 lbs. Water, 100 gallons.

\section{Amoniacal Copper Carbonate}

Copper Carbonate, 5 ounces. Ammonia, 2 pts. Water, 50 gallons.

The copper carbonate is best dissolved in large bottles, where it will keep indefinitely, as it should be diluted with water as required. For the same purpose as Bordeaux.

\section{Copper Sulphate Solution}

Copped sulphate, 1 pound. Water, 25 gallons.

This should be used only before the foliage appears. It is easily applied, and acts as a general germicide and disinfectant. In simply solution copper sulphate is very injurious to foliage. When lime is added, as in making Bordeaux mixture, its corrosive action is neu. tralized and injury to the foliage prevented. In this way a larger quantity of bluestone may be used, and it adheres to the foliage better by the agency of lime.

\section{Bordeaux Mixture}

Copper Sulphate .......4 pounds Quicklime ............4 pounds

Water ..............50 gallons

To destroy leaf-eating insects, add four ounces of Paris Green. For Peach, use three pounds each of copper sulphate and lime, and three ounces of Paris Green, on account of the tenderness of the foliage.

Ferrocyanide Test-Dissolve one ounce of yellow prussiate of potash in a pint of water and label "POISON." Drop it into the mixture and if it turns brown more milk of lime should be added. Add milk of lime until the solution will not turn brown.

\section{Hellebore}

Fresh White Hellebore, 1 oz. Water,3 gallons.

\section{Kerosene Emulsion}

Hard Soap ..........1/2 pound

Boiling Water .......... I gallon

Kerosene .............2 gallons

Dissolve the soap in hot water and while hot add the oil. Pump the liquid back into itself 5 or 10 minutes until it becomes a creamy mass.

For a 10 per cent emulsion add 17 gallons of water to 3 gallons of the above emulsion.

For a 15 per cent emulsion add $10 \frac{1}{2}$ gallons of water to 3 gallons of the above emulsion.

\section{Lime Sulphur Salt Solution}

Stone Lime .......... 15 pounds

Flower of Sulphur ..... 15 pounds

Common Salt ......... 15 pounds

Put lime in kettle, add three or four buckets hot water. While lime is boiling, add sulphur and stir briskly. If contents of kettle is likely to boil over, add another bucket of hot water. When the lime and sulphur have boiled for a few minutes, add the salt, and cook until the solution becomes dark amber in color. Usually an hour is sufficiently long to cook the mixture, but if it is not of the right color at this time, the cooking should be continued. When the mixture has been properly cooked, there ought not to be more than a pint or so of residue left in the kettle. At the beginning of the cooking, stir continually, but after a few minutes, occasional stirrings will suffice. When the cooking is completed, the solution should be strained through a fine sieve, made for the purpose, or through a gunny sack into the pumping barrel or tank and made up to 50 gallons of hot water. The mixture should be applied while hot and preferably as soon after making as possible, always bearing in mind to keep it well agitated while the pump is in operation. Pumps and accessories used should be well washed and cleaned after each time of using.

Concentrated lime-sulphur solutions may be purchased from the manufacturers, of which there are now a larger number making a good product, and can be used according to directions furnished with each package.

\section{Tobacco}

Boil tobacco stems, and use at the rate of two gallons to each pound of stems, for sucking insects.

\section{To Agents}

If this descriptive catalogue is carefully studied, it will yield a large amount of valuable information. In selling stock you may give purchasers dozen rates for half-dozen lots, and hundred rates for lots of fifty and upward.

Study up whatever you have decided to push as your specialty. Don't try to learn all about everything, simply study on what you decide you can sell in the territory you intend to work. You will find in your price list, prices on nearly everything unless it is something new that has been introduced since price list was issued. 


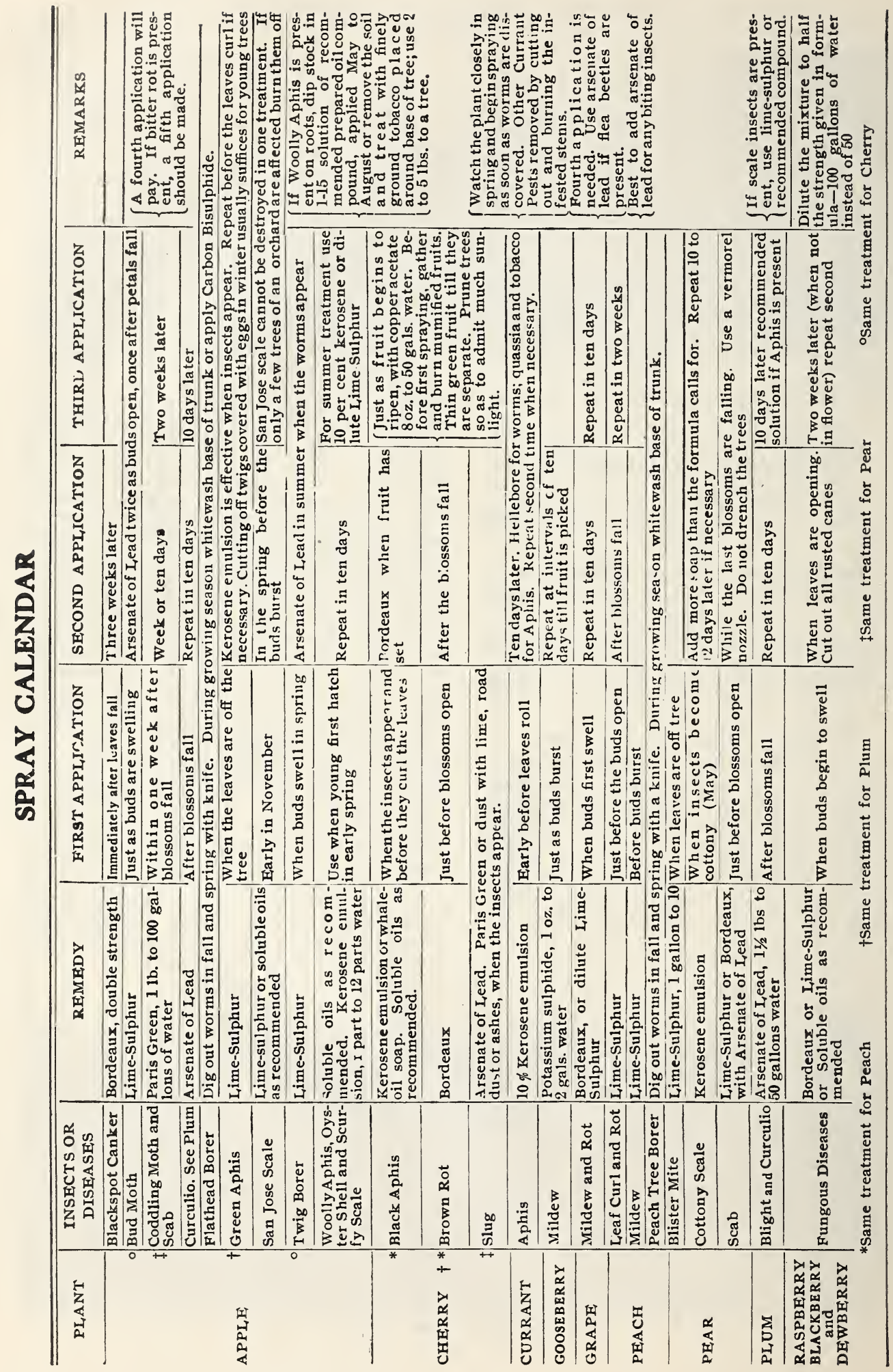




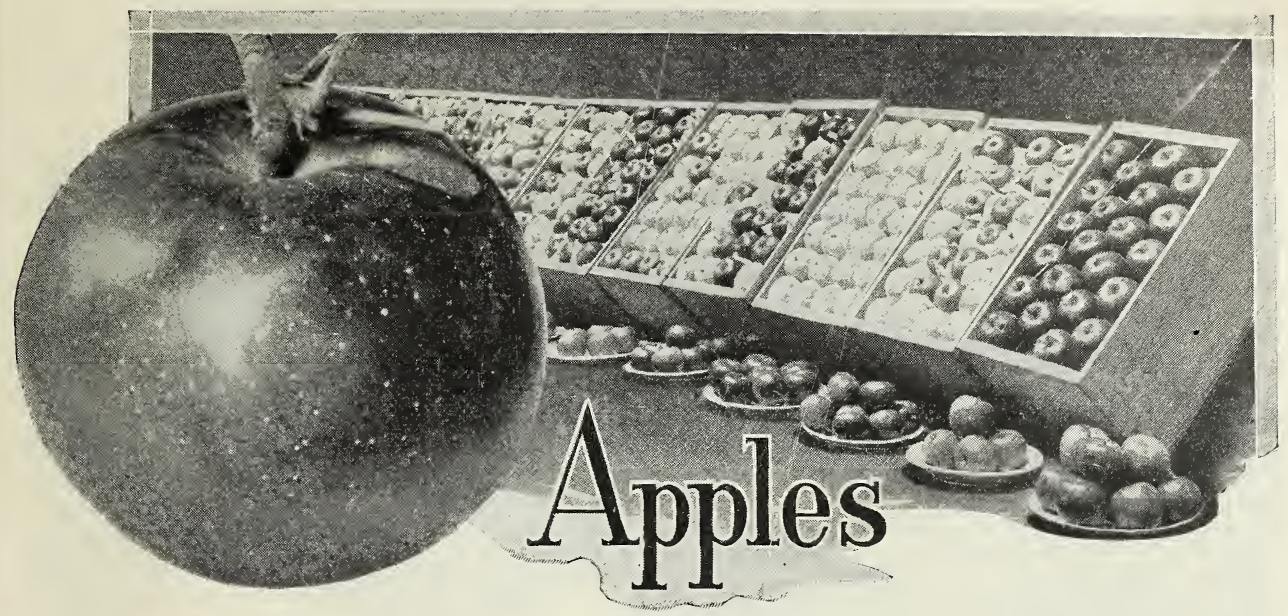

$\mathrm{T}^{\mathrm{HE}}$ capital letters following the names of varieties and descriptions are a key to the location where that particular fruit thrives best: $\mathrm{N}$ means North; FN Far North; C is for Central; S for South. Varieties followed by NCS may be planted North, Central or South. CS indicates varieties adapted to Central or Southern States; CFN Central to Far North; SFN South to Far North and $\mathrm{S}$ for South only. This area reaches from the Gulf of Mexico to Hudson Bay and from Atlantic to Pacific.

\section{SUMMER VARIETIES}

\section{Benoni \\ Caroline June \\ Early Harvest

Golden Sweet
Keswick Codlin
Primate

Benoni. A small, yellow apple with red cheeks. Has a rich, juicy taste and cooks fine. Tree hardy, but not much grown because very little demanded for the fruit market. Season August and September. NCS.

Carolina June.-(Red June)-Popular at the south and west; small to medium, deep red, productive, hardy and a free grower. August. NCS.

Early Harvest.-Medium size, pale yellow, mild, fine flavor and popular for both dessert and cooking. Ripens early and is very productive. Subject to fungous in some sections unless sprayed with Bordeaux. Grows in all good apple districts and is very productive. Trees do not grow very large. Ripens in $\mathbf{A u}$ gust. NCS.

Golden Sweet.-Large, yellow; a very fair, sweet apple. Tree a free grower and good bearer. August and September. NCS.

Keswick Codlin.-Large, oblong, pale yellow; tender, juicy and pleasant acid; excellent for cooking. The tree bears very young and abun. dantly, making it a valuable orchard variety. July to October. NCS.
Red Astrachan

Sops of Wine

Strawberry

Sweet Bough

Tetofsky

Yellow Transparent

Primate.-A fine apple for home use, but too tender for shipping. Tree is very hardy, vigorous and very productive. Fruit is good size, light yellow with slight blush, very pleasant flavor. Will succeed in all apple sections. Season August and September. NCS.

Red Astrachan.-One of the most toothsome of early varieties, very handsome. Trees grow perfect in proportions. Apples medium in size, but uniform. Flesh is white, tender, streaked with red, juicy, having a rich, acidtart taste. Excellent for cooking or dessert. The best early market apple, as it ripens in August. Brings highest market prices. NCS.

Strawberry, (Early Strawberry.)-Tree a moderate, erect grower and good bearer. Fruit medium size, mostly covered with red. Flesh tender, mild and fine flavored. Season, middle to end of August. NOS.

Sweet Bough.-A fine apple for baking or to eat out of hand, but too perishable as a market variety. Baked whole and eaten with cream it is delicious. Large, pale yellow, tender and sweet. Tree will grow in all good apple dis. tricts and should be included in the home garden. Season August. Origin, United States. NCS. 


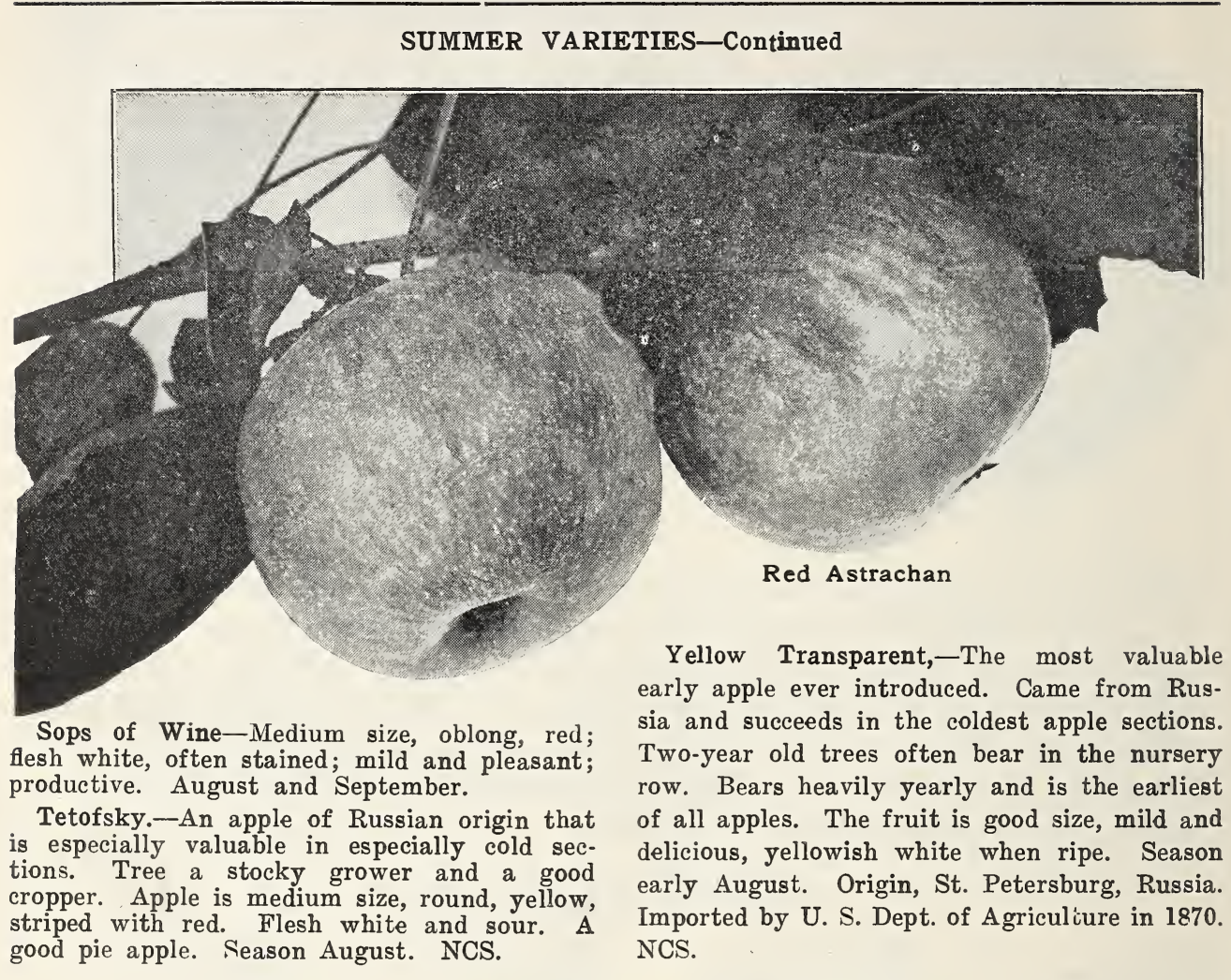

\section{FALL VARIETIES OF APPLES}

$\begin{array}{ll}\text { Alexander } & \text { Gravenstein } \\ \text { Autumn Strawberry } & \text { Haas } \\ \text { Duchess } & \text { Jersey Sweet } \\ \text { Fall Jennetting } & \text { Lowell } \\ \text { Fall Pippin } & \text { Maiden's Blush } \\ \text { Fameuse } & \text { Munson's Sweet }\end{array}$

Alexander.-Tree hardy and productive, bears early. Fruit is round and large with a rich, yellowish green skin intermingled with russet spots. Flesh white, juicy and snappy; very nice eating apple. Good for cooking and an extra fine shipper. In bearing from September 15 to November 15 . Tree very hardy, will grow almost anywhere. NCS.

Autumn Strawberry.-Medium, round, flesh white, striped and splashed with red, tender and juicy, very' pleasant flavor; bears young and abundantly, and is annually loaded with fruit of fine quality. October to December. NC.

Duchess of Oldenburg.-A Russian apple. Large, roundish, streaked with red and yellow; flesh whitish, juicy, and sprightly sub-acid; ripening in the Fall; tree a vigorous grower, having fine, large foliage, bearing abundantly and when very young; very hardy, succeeds in nearly all sections of the country, and is as valuable in the extreme north as in the south.

Okabena
Peerless
Plumb's Cider
Porter
Pound Sweet
Rambo

Red Beitigheimer
Sherwood's Favorite
Smoke House
St. Lawrence
Stump
Twenty Ounce

We can recommend this to our patrons all over the country. September. NCS.

Fall Pippin.-Very large, yellow, tender, juicy and rich. A general favorite as a fall cooking apple. Pleasant, aromatic flavor when eaten. Tree is vigorous, hardy and productive, but fruit is quite subject to moss spots. Season October to December. American origin (probably seedling). NCS.

Fall Jennetting.-Large, pale yellow with a blush on the side exposed to the sun; flesh white, tender and juicy; mildly sub-acid; and good grower and regular bearer. September and October. NCS.

Fameuse or Snow Apple. -One of the best table apples. Medium size, deep crimson color. Inside is snowy white and delicious. Firstclass for all markets, and will do well North. Tree is vigorous and productive. Season October to December. Origin Quebec. NC. 


\section{FALL VARIETIES-Continued}

Gravenstein.-The best apple for its season for either home use or market. Brings good price. Fruit is large, greenish yellow, striped with red. Has a rich, spicy flavor. Tree is adapted to all apple sections, and bears regularly heavy crops of finely shaped, handsome fruit. This is a good variety to plant. Season late September to November. NCS.

Haas.-(Gros. Pommier. Fall Queen) Medium to large, slightly conical and somewhat ribbed; pale greenish-yellow, shaded and striped with red; flesh fine, white, sometimes stained; tender, juicy; sub-acid, good. Tree vigorous and very hardy; upright grower with well-formed head; bears early and abundantly. September to November.

Jersey Sweet.-Medium; striped red and green; very sweet, rich and pleasant. Good grower and bearer. September and October. NCS.

Lowell.-(Orange, Tallow or Grassy Pippin) -Large, oblong; skin oily, pale yellow; brisk, juicy, rather acid flavor. Good for table and cooking, September and October. NC.

Maiden's Blush.-A standard variety for the commercial orchard. Bears young and is a prolific cropper. A fine hardy tree and the fruit usually brings an extra price. Fruit is good size and handsome. Rich yellow color with bright red cheeks on the sunny side. A tender, juicy apple; first class for cooking or eating. Season September and October. Origin New Jersey. CS.

Munson's Sweet.-Medium to large; pale yellow with a red cheek; tender, juicy and good. Tree a vigorous grower and good bearer. October and November. CS.
Okabena.-Origin, Minnesota. Season, August to October. Vigorous, absolutely hardy, and an ideal orchard tree in every respect. Bears very young and a good crop may be depended upon. Fruit, medium to large; yellow striped and splashed with carmine, which is heavy on sun-side. Flesh, yellowish-white, fine grained, crisp and juicy. Flavor, sprightly subacid. Quality, excellent. Ripens after Duchess and valuable in market on that account. A Seedling of the Duchess and an excellent dessert apple.

Peerless.-Now growing in fifty-six counties in Minn., in ten states and also in Manitoba. The crop of 1892 from the original tree was worth $\$ 12.00$ at the market price. This after the tree had been severely cut for scions, each fall for the six previous years. This variety blooms later than other apples. On June 6th, 1892, it was in full bloom; blooming late makes it bear a great many years, when frosts kill even crab apples.

Plumb's Cider.-A native of Wisconsin, where its hardiness has been abundantly proved. Tree vigorous, round-headed and productive. Flesh, whitish, fine, tender, juicy, mild, sub-acid. September to January.

Porter.-Rather large; yellow, tender, rich and fine. Moderate grower but productive. September.

Pound Sweet (Pumpkin Russet).-A very large, round, yellowish russet apple; very sweet and rich. Tree a vigorous and rapid grower. October and November.

Rambo.-Medium; yellowish, streaked with dull red and somewhat dotted; mild, tender and good. Fine grower, productive; more especially valuable in the West. October to December.

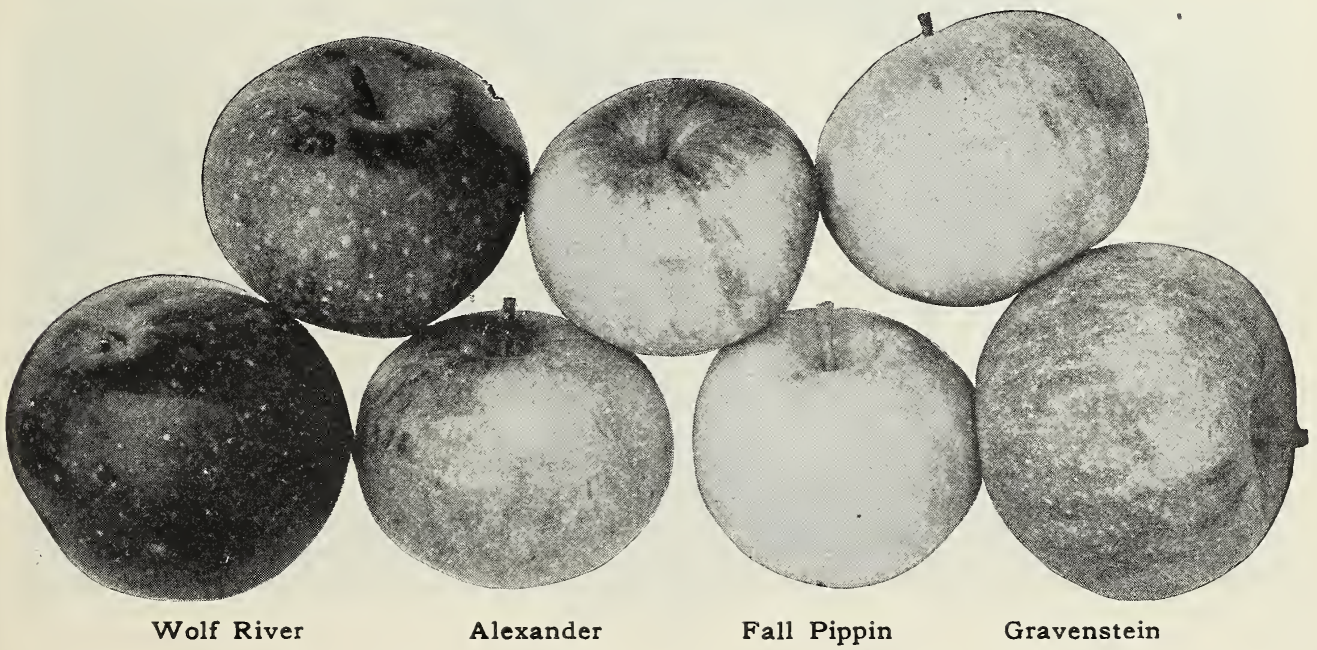




\section{FALL VARIETIES-Continued}

Red Beitigheimer.-A rare and valuable German variety. Fruit looks fine and grows very large. Skin whitish yellow almost covered with pale red. Not first class for eating, but ^ good cooking variety. Tree is hardy, a strong grower and a heavy cropper. Season, early fall, September. Origin, Germany. NCS.

Sherwood's Favorite, or Chenango Strawberry.-Medium size; oblong and indistinctly ribbed; of a light color, splashed with dark crimson, flesh white, juicy, very mild and ten. der, slightly sub-acid Very much esteemed for the table, and popular wherever grown. September.

St. Lawrence.-Not much planted of late years, but is a delicious apple for early fall use. Valuable in Canada and Northern states because extremely hardy. Fruit large, with yellowish skin heavily striped with carmine. Quality first class in every respect. Season, September and October. Origin, Montreal, Can. ada. NCS.

Smoke House-Large, yellow, shaded with bright red; flesh firm, crisp, juicy and fine flavored. Especially esteemed in Central states. October and November. NC.

Stump.-A good looking fall apple. Good size, pale yellow striped with red. Fine qual. ity. Valuable for home use and for nearby markets. September to October. Origin, United States, possibly Monroe County. NCS.

Twenty Ounce.-Very large, nearly round; yellow, striped with red; quality good; vigorous and good bearer; popular as a market variety. November and December.

\section{WINTER VARIETIES OF APPLES}

Arkansas Black

Bailey Sweet

Baldwin

Baxter

Belle de Boskoop

Bellefleur, Yellow

Ben Davis

Bismark

Boiken

Bottle Greening

Delicious

Dominee

Fallawater

Franklin Sweet
Gano

Gideon

Greening, R. I.

Grimes' Golden

Golden Russet

Hubbardston Nonesuch

Iowa Blush

Jacob's Sweet

Jonathan

King of Tompkins Co.

Longfield

Mammoth Black Twig

Mann

McIntosh Red
Milding

Milwaukee

Newtown Pippin

Northern Spy.

North Star

N. W. Greening

Patten's Greening

Peerless

Peck's Pleasant

Pewaukee

Rawle's Janet

Rome Beauty

Roxbury Russet

Salome
Smith's Cider

Seek-no-Further

Spitzenburg

Stark

Stayman's Winesap

Sutton Beauty

Tolman Sweet

Wagener

Walbridge

Wealthy

Winter Banana

Wismer's Dessert

Wolf River

York Imperial

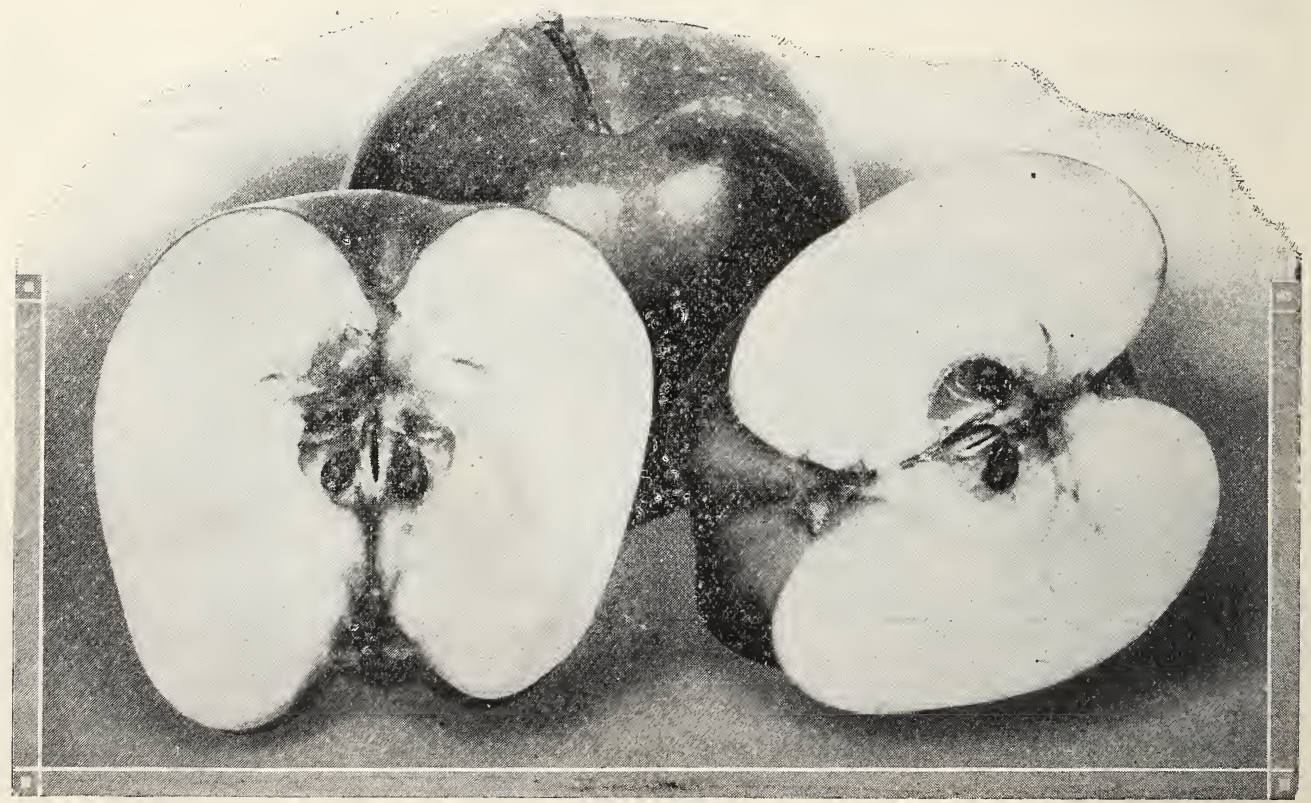


WINTER VARIETIES-Continued

Arkansas Black.-Fruit large, round, oblong, covered all over with very dark red. Much darker than Wine Sap; flesh orange-yellow; a splendid keeper. December to April.

Bailey Sweet.-Large; deep red, tender, rich, sweet; vigorous, upright, good bearer. November to April.

Baldwin.-The most popular winter apple for shipping and the heaviest bearer. Baldwin orchards should be mixed with other varieties, such as $\mathrm{King}$, Northern Spy, Russets, etc. The fruit is much better. Tree grows rapidly and its fruit is large, round, with red and yellow skin. Flesh yellowish and tart. One of the best apples for both American and export trade. A fine keeper in orninary dry cellar. Comes into heavy bearing in eight years. Will bear some in five years. If your orchards are tilled and the trees sprayed and properly trimmed you will bring fruit much quicker. NC.

Baxter.-A fine, large, red apple which brings " big price in all markets. Some what subject to fungus. Tree is a good grower, hardy, but only moderately productive. Flesh is white with red streaks; slightly sour; not very juicy, but a first-class cooking apple. Season October to January. NC.

Belle de Boskoop.-This apple is a late keeper and is of good quality for either eating or cooking. You'll find it rich flavored, tender and juicy. Medium in size. Color yellow with red cheeks. Tree bears early and heavily, is a good grower and will do well in cold climates. Season February to April. NCS.

Ben Davis.-Once very popular, but falling in favor. Can be shipped around the world without hurting it; is a good color, a heavy producer, but quality medium to poor. Makes a fair cooking apple. Fruit runs medium in size. Yellow skin with red stripes. Still popular for export, but little demand for home use. Season January to May. A seed. ling brought from North Carolina to Kentucky by Mr. Ben Davis, about 1820 . NCS.

Bismark.-Tree is short, stocky and healthy. Bears very young. Often used as a filler in orchards of later bearing varieties. Originated in New Zealand and has been planted wherever apples are grown. Fruit is large, yellow, with red cheeks; fine for eating and keeps well into the winter. NCS.

Bellefleur, Yellow.-A valuable apple because of its good quality all through the winter. Tree is hardy and a strong grower. Does well on light, sandy soils. The fruit is large, yellow with blush on sunny side, crisp and fine flavored in season. Bruises easily but valuable

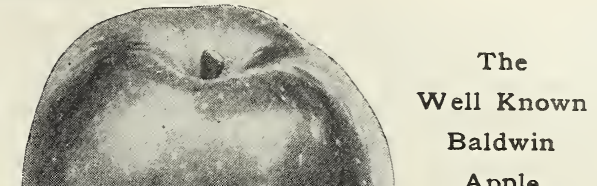

Apple 


\section{WINTER VARIETIES-Continued}

dition. In tree Delicious is tree perfection and one of the strongest, hardiest and most vigorous growers among apples; aphisresistant and a late bloomer, the hardiest in bud, the best pollenizer; blossoms strongly frost-resistanta most important and valuable feature. Bears annually.

Dominee.-A large, flattened, greenish-yellow apple, with red stripes; flesh, white, tender, juicy. Good grower, very productive; finest in the West. November to April.

Fallawater-(Tulpehocken)-Very large, yellowish-green with dull red cheek. Juicy and a good cooking apple. Tree a strong grower and very productive even while young. Season January to March. NCS.

Franklin Sweet.-Originatèd in Franklin Co., Me., and is considered very desirable. Perfectly hardy and good quality; fair size; flesh white and very juicy; color similar to Bellefleur. Has been kept until March. A very valuable winter sweet apple.

Gano.-Good size, deep red with tender yellow flesh. A good keeper and shipper. Tree is a strong grower and bears well. Fruit has peculiar cone shape. Season, February to May. NCS.

Gideon.--Raised in Minnesota, from Crab seed by Mr. Gideon. An. upright grower; medium to large; color yellow, with vermilion blush on sunny side; mild acid; quality very good. October.

Golden Russet.-Medium size and clear golden russet color. A good apple in colder sections and brings good prices. Keeps till May in a cold cellar, and is then rich and sweet. Tree grows rather willowy; moderate producer. Season November to April. Origin, Western New York. NCS.
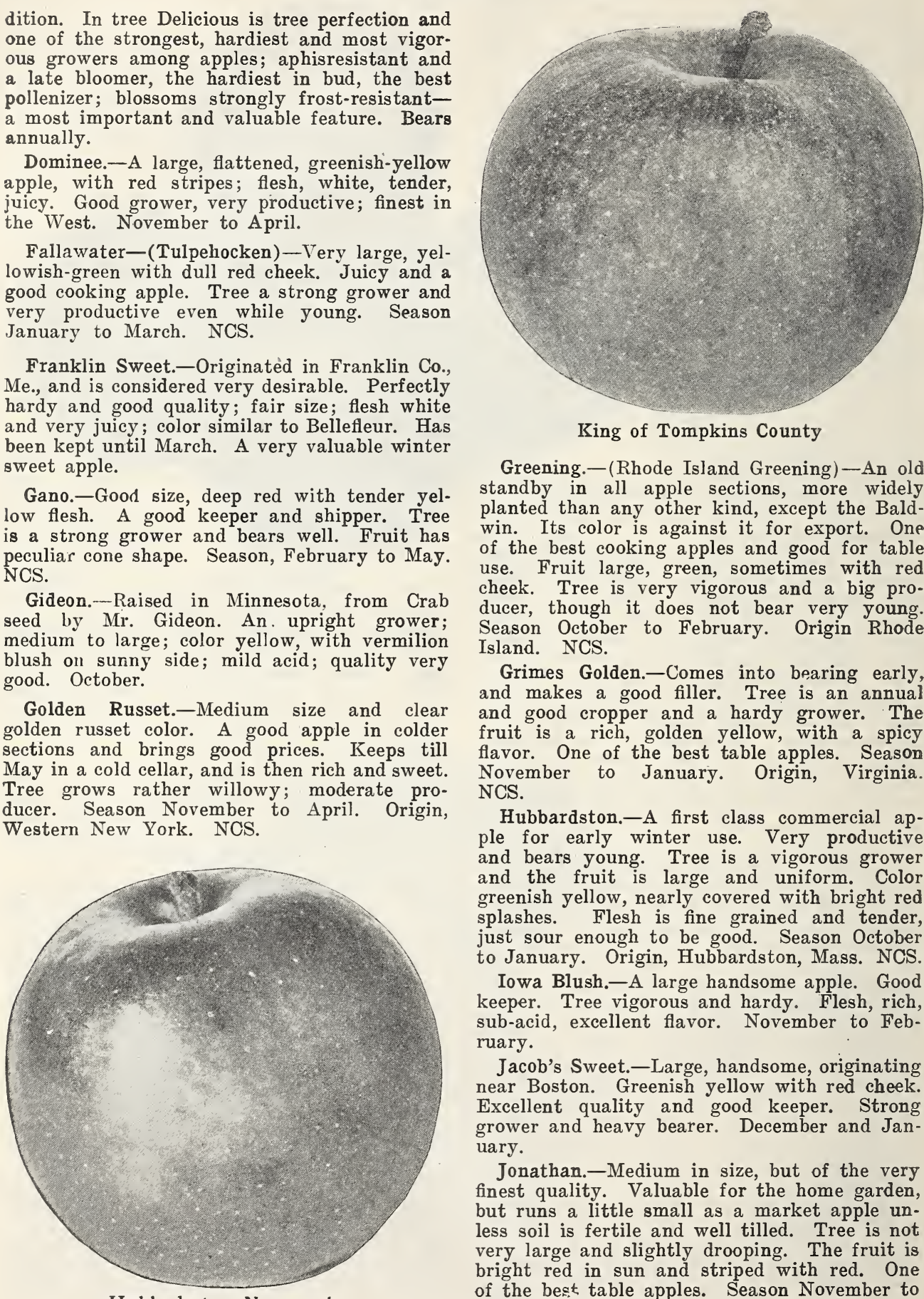

\section{King of Tompkins County}

Greening.-(Rhode Island Greening)-An old standby in all apple sections, more widely planted than any other kind, except the Baldwin. Its color is against it for export. One of the best cooking apples and good for table use. Fruit large, green, sometimes with red cheek. Tree is very vigorous and a big producer, though it does not bear very young. Season October to February. Origin Rhode Island. NCS.

Grimes Golden.-Comes into bearing early, and makes a good filler. Tree is an annual and good cropper and a hardy grower. The fruit is a rich, golden yellow, with a spicy flavor. One of the best table apples. Season November to January. Origin, Virginia. NCS.

Hubbardston.-A first class commercial apple for early winter use. Very productive and bears young. Tree is a vigorous grower and the fruit is large and uniform. Color greenish yellow, nearly covered with bright red splashes. Flesh is fine grained and tender, just sour enough to be good. Season October to January. Origin, Hubbardston, Mass. NCS.

Iowa Blush.-A large handsome apple. Good keeper. Tree vigorous and hardy. Flesh, rich, sub-acid, excellent flavor. November to February.

Jacob's Sweet.-Large, handsome, originating near Boston. Greenish yellow with red cheek. Excellent quality and good keeper. Strong grower and heavy bearer. December and January.

Jonathan.-Medium in size, but of the very finest quality. Valuable for the home garden, but runs a little small as a market apple unless soil is fertile and well tilled. Tree is not very large and slightly drooping. The fruit is bright red in sun and striped with red. One of the best table apples. Season November to Hubbadsrton Nonesuch February. Origin, Woodstock, N. Y. NCS. 


\section{WINTER VARIETIES-Continued}

King of Tompkins County.-A standard commercial variety. Hard to beat for either table use or cooking. Looks well for market and is just as good as it looks. Fruit. bright red and uniform and large. Always brings a fancy price over other varieties. Keeps well in cold storage. Flesh is yellow, crisp and juicy. Tree is vigorous and a good cropper. Season October to February. Origin, New Jersey. NC.

Longfield.-A Russian variety imported some years since. Tree a free, upright grower, early and abundant bearer; medium to large; yellow with a blush on sunny side like the Maiden's Blush; rich, sprightly sub-acid; quality as good as the Fameuse and somewhat like it. December to March.

Mammoth Black Twig.-(Paragon)-One of the most profitable of all apples. Resembles the Wine sap, but is a better grower. An excellent keeper.

Mann.-Fruit medium to large, roundish ob late, nearly regular; skin deep yellow when fully ripe; flesh yellowish, half fine, half tender, juicy, mild, pleasant, sub-acid. The tree grows straight and symmetrical and makes a large tree in the orchard. It is an early and annual bearer.

McIntosh Red.-A very fine table apple for early winter use. Attractive in appearance, deep red and good size. Flesh is white, crisp, tender, juicy and aromatic. A first class apple for home markets and a good shipper. Tree is hardy; a good annual cropper, and comes into bearing young. It requires several pickings as the fruit ripens unevenly. Season November to January. Origin, John MeIntosh, Dundela, Ont. ENCS.

Milding.-Fruit large, skin smooth, whitishyellow, splashed with rich red; flesh tender, juicy, sub-acid; tree a strong, fine grower and very productive. December to February.

McMahon White.-Tree productive and healthy. Fruit large and of fine quality and flavor. A splendid apple for winter use.

Milwaukee.-Seedling of the Duchess. Large, oblate, smooth and regular; yellowish, splashed and shaded with deep red; flavor, pleasant with spicy aroma. Tree, strong and healthy grower and hardy. December to March.

Newtown Pippin-(Albemarle Pippin)-One of the best keeping varieties that can be grown. Brings highest prices in the English markets. Tree needs rich soil and cultivation to do its best. Grows rather slowly and is not extremely hardy. Fruit is good size, bright yellow with a pink blush, rich flavored, firm and juicy. Season November to June Origin, Newtown, Long Island. NCS.

Northern Spy.- This variety stands third in commercial importance in the Eastern fruit sections. Fruit large, fine color, bright red unless shaded too much, with a delicate bloom. Flesh is juicy, crisp and tender. Many perems prefer it to any other for table use or cooking. Always brings highest market prices. Ready to eat in November and will keep in storage until June. Tree very thrifty. Origin, near Rochester, N. Y., about 1850. NC.

North Star. - (Dudley's Winter)-Large; very handsome; perfectly hardy, vigorous, quality fine; a seedling of Duchess, which it resembles, but less tart and better quality.

Northwestern Greening.-A greenish yellow apple sometimes faintly marked with red. One of the best winter apples for sections that are too cold for the R. I. Greening. Tree thrifty and very hardy. Fruit large and of good flavor. Season December to April. Origin, Wisconsin, about 1872 , by E. W. Daniels. ENS.

Patten's Greening.-Seedling of the Oldenburg and equals it as an orchard tree in hardiness and bearing. Large uniform size; pleasant, acid, good equally for eating and cooking. Season October to January or later.

Pewaukee.-A good commercial apple for cold sections. Can be grown either north or south. A fair eating apple and one for cooking. Medium size, bright yellow splashed with dull red. A good shipper. Season January to May. Origin, G. P. Peffer, of Pewaukee, Wis. Crossed Oldenburg and Spy. NCS.

Peck's Pleasant.-Fruit medium size, green with red blush. Flesh is crisp, fine grained and juicy. Very pleasant flavor. Quality very good to best. Season October to March. ENCS.

Rawle's Janet. - (Never fail) - M e d i u mi, roundish, ovate, greenish-yellow, streaked with red; crisp, rich and juicy; one of the best and longest keepers in the South and Southwest.

Red Canada.-(Old Nonsuch of Mass., Steele's Red Winter)-Medium, oblate, red, tender, crisp, rich. sub-acid, refreshing and delicious. Tree, thrifty, but a slender grower. Productive January to May.

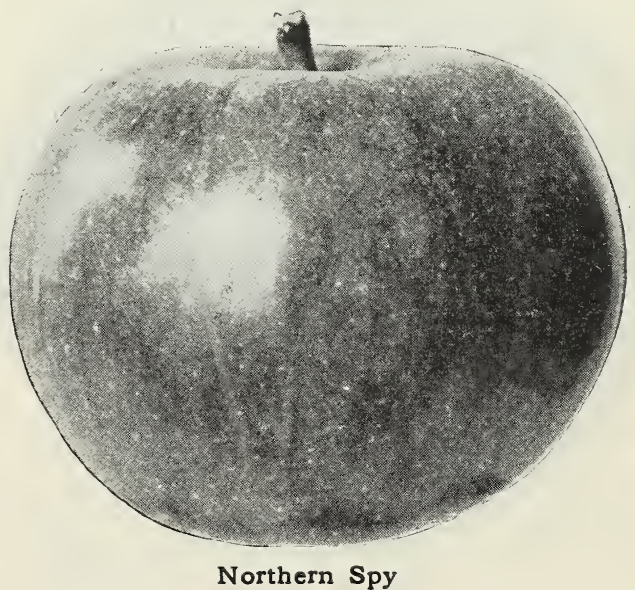




\section{WINTER VARIETIES-Continued}

Russet-(Roxbury or Boston)-A staple export variety. One of the best shippers and keepers. Medium size, dull green nearly covered with russet. Skin tough, flesh mild and appetizing. Good in all markets and maybe all apple districts. As hardy as the Greening. Season January to June. Origin, Massachusetts. FNC.

Rome Beauty.-Large, yellow, shaded with bright red; flesh yellowish, tender, juicy, subacid; moderate grower. November to February.

Salome.-New, hardy, productive; keeps the year around; ripens into fine condition in winter and remains fresh, plump and juicy till summer. Has stood the test and proved itself without a rival. January to May.

Seek-No-Further.-An old commercial variety and still valued by some growers. Fruit is medium to large in size, striped with dull red and russet, tender, rich, spicy and fine. Succeeds well in Eastern States. Season November to February. Origin, near Westfield, Conn., about 1796 . NCS.

Smith's Cider.-Medium, striped; flesh tender, juicy, sub-acid; very popular in Pennsylvania and Western States. December to March.

Spitzenburg (Esopus.)-One of the finest apples for winter use. Widely planted by early settlers because of its fine flavor. Not profitably commercially because tree is not a strong grower and bears lightly. Fruit medium size, conical, nearly covered with bright red. Season November to February. Origin, Esopus on Hudson River, 1798. NCS.

Stayman Wine Sap.-Medium to large, smooth, thick skin, yellowish green often nearly covered with dull red. Taste juicy and pleasant. Season December to May. NCS.

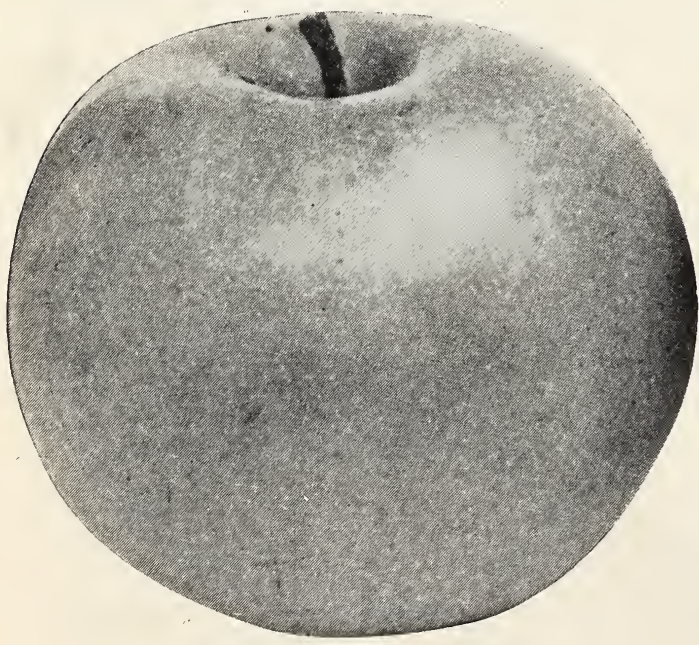

Winter Banana
Stark. - A good profitable winter apple for export. Somewhat better than Ben Davis. Good for cooking, poor for eating. Large fruit, dull red color on greenish ground. Keeps till late. Tree is a stout, vigorous grower and very productive. Succeeds over a wider territory than either the Baldwin or Greening. Season, January to May. Origin, Ohio. NCS.

Sutton Beauty.-A really valuable market variety because the fruic is good quality, keeps well and the tree is very vigorous and productive. A large, roundish apple, yellow skin striped with crimson. Tender, crisp and juicy; just right for eating out of hand or for cooking. December to February. NCS.

Tolman Sweet.-The best winter sweet apple. A favorite with all who like sweet apples. Tree will grow anywhere that apples can be grown and bears heavy crops. A good variety on which to top-graft more tender varieties. The apple is medium size, light yellow, firm, fine grained and very sweet. Keeps well through the winter. Season November to April. Origin, Rhode Island, U. S. A. NCS.

Waloria - e.--Medium size, striped with red; handsom ind of excellent quality; vigorous grower and productive; very hardy and considered of great value in the North and Northwest. March to June.

Winter Banana.-Very handsome, golden yellow with tint of red on sunny side. Takes its name from the fact that its rich flavor resembles that of a banana. An apple of fair quality. Season, January to July. NCS.

Wagener.-A fine dessert apple but needs plenty of sun to bring out a good color and Havor. Fruit grows large, yellow, nearly covered with crimson. Tree bears early but is not lived lived. Makes a good filler. Apple is tender but valuable for home markets. Season, December to May. Origin, Abram Wagener, Penn Yan, N. Y., in 1796. NCS.

Wealthy.-Here's an apple that is extremely hardy and one of the heaviest bearing kinds we know of. Will succeed anywhere that apples can be grown. Apple is large when well grown. Pale yellow with rich red cheek. None better for table use or cooking. Tender and juicy. Tree bears quite young. Season October to January. Origin, Peter Gideon, St. Paul. Minn. NCS.

Winesap.-Medium, dark red, sub-acid, excellent. Tree a moderate grower and abundant bearer. A favorite market variety in the West. December to May.

Wismer's Dessert.-Size medium to large'. Smooth, beautifully colored with yellow, shaded with bright red, in strips and blotches marked with russet dots. Exquisite, delicious flavor, juicy, melting, buttery, pear like texture. Tree a strong grower, and extremely hardy. Originated in Northern Ontario, Canada. Season, November to April. 


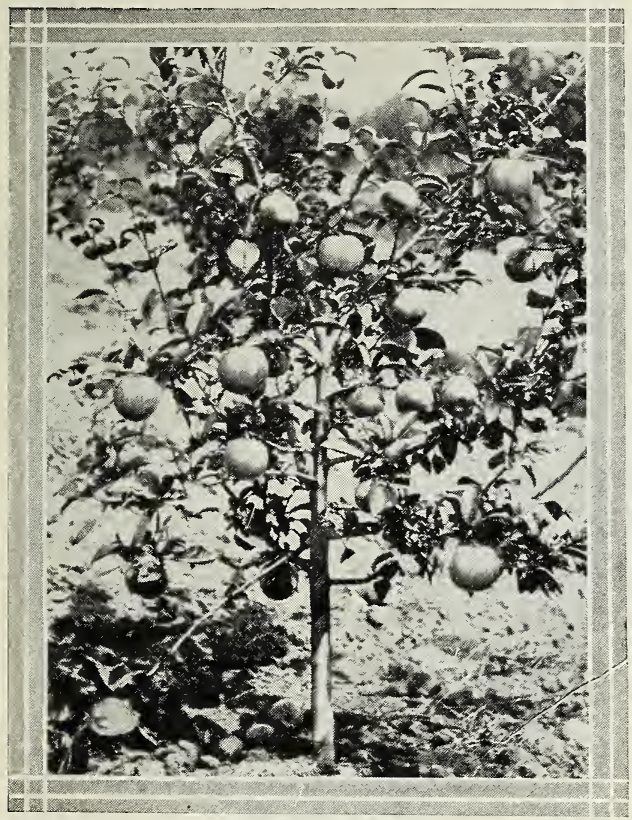

McIntosh Dwarf (Doucin) 3 Years Old
Wolf River.-Tree hardy and productive. Fruit large and handsome, rich red in color, flesh white and of exceedingly fine quality, sub-acid. October to December. NCS.

York Imperial (Johnson's Fine Winter) - A good shipper and keeper, making it in de. mand for the export markets. Tree is a vigor. ous grower and a pretty regular bearer. Does best on heavy soils. Not at its best north of Pennsylvania. Apple is smooth, blushed and striped with red. Flesh is yellowish, tender and mildly acid. Ready to eat in Jan. uary and keeps until April or May. Season, January to April. Origin, York County, Pa. NCS.

\section{DWARF APPLES}

Standard apple trees are propogated by budding or grafting onto roots of French Crab. which produces the tall growing trees. Doucina and Paradise stocks render the tree dwarf in: type. The Paradise stock produces trees which. will not grow more than 8 or 10 feet high. On. the Doucin stock they may attain a height of 15 or 20 feet but can be kept lower.

\section{CRAB APPLES} W'THIN the past few years much attention has been given to improving this
class of fruit, because of their adaptability to cold sections, where only a few varieties of apples can be successfully grown. These efforts have been attended with marked success. Crap Apples succeed equally well in all sections, and are valuable for cider, preserving, jelly, ornament, and some of the improved sorts are excellent for eating. Sent to the Eastern markets they.command a very high price.

Excelsior.-Fruit very large, being nearly as large as a medium sized apple. Color yellow splashed with red. A good cooking apple because of its fine flavor. Ripens early. Tree hardy and productive. Season September and October. NCS.

General Grant.-Tree an erect, vigorous grower; fruit in dense clusters; quality equal to Duchess of Oldenburg. October to December.

Hyslop.-Very popular because of its large size, beautiful red color and hardiness. Sharp acid flavor. Good for preserves, jellies and cider. Season October and November, but may be kept well into winter in cool cellars. NCS.

Large Red Siberian.-About an inch in diam. eter, grown in clusters; yellow, lively scarlet cheek. Tree, erect, vigorous, bears young and abundantly. September and October.

Large Yellow Siberian.-Nearly as large as above; fine amber or golden yellow color.
Martha.-Another good variety for all sections. A rapid grower and a great bearer of handsome fruit. Bright, glossy yellow shaded with bright red. Fine tart flavor, surpassing all others for culinary purposes. Season, October and November. NCS.

Transcendent.-All things considered, this is one of the most valuable varieties of crab apples grown. Tree remarkably vigorous and immensely productive. Makes a fine market apple. Golden yellow with rich crimson cheek. Good flavor. Season September and October. NCS.

Van Wyck.-A large, sweet crab. Skin mottled with bright red. Tree vigorous, exceedingly hardy. Season September. NC.

Whitney.-A very hardy and prolific variety. Fruit is handsome and delicious. Excels for making fine jellies and preserves. Season, lato September and October. NCS. 


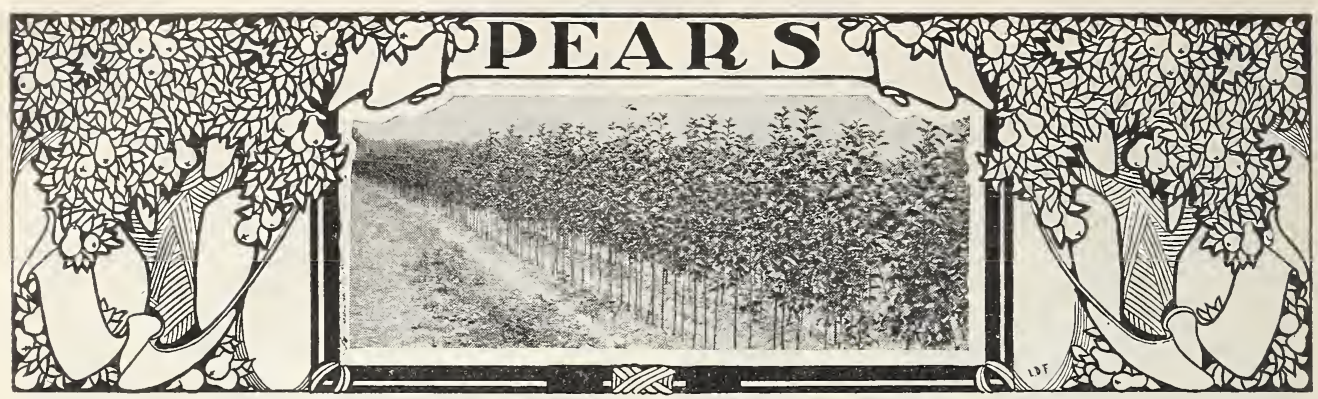

DEAR production is not in proportion to the demand. There is a vast undeveloped field for the grower who produces pears for his own enjoyment and disposes of his surplus in the home markets, and only in the last few years have orchardists realized the wonderful profits that come from a commercial pear orchard of good varieties. The pear tree will thrive on any kind of land and will bear profitable crops on a shallow soil, but does best on a loose, strong, clay soil. A dressing of coarse manure when the tree is planted is beneficial, but the pear tree requires very little fertilizer as compared with other trees. The young orchard after planting should have several years of clean, thorough cultivation, then it will thrive in sod, especially on richer soil, as the tree is naturally a vigorous grower.

Dwarf pears must always be planted sufficiently deep to cover the junction of the Pear and Quince two or three inches-the soil made rich and well tilled, and about one-half the previous summer's growth cut off each spring. Under this treatment Dwarfs are everywhere successful. The side branches should not be removed higher than one foot from the ground in Dwarfs, while Standards may be trimmed to the height desired. Train in pyramidal form.

Ripen the fruit in the house. Gather when, on gently lifting the fruit, the stems will readily separate from the limb. Place in a dark room until fully matured. Winter Pears may hang on the trees until there is danger from frost, then place in a dry cellar for maturing.

The letters "D or S" appended to the description of varieties, indicate favorable growth either as "Dwarfs" or "Standards," and when placed together, that they succeed as either.

\section{SUMMER}

Bartlett.-No pear of the same season equals the Bartlett in flavor, either for eating or canning. Has first place in all markets and brings top prices. Fruit large and yellow, fine grained, buttery and juicy. Sweet, rich flavor. Tree is fairly hardy, grows very rapidly and bears young and heavily. Carefully cultivated and sprayed trees will produce enormous crops of perfect fruit. Season September.

Clapp's Favorite.-The Clapp is a beautiful pear and of good quality, making it a profitable market variety. Must be picked early and shipped while firm, as it soon passes out of prime condition. Tree is an upright and very vigorous grower, and bears heavy crops of large, juicy pears with a very agreeable flavor. This is one of the hardiest pears. Season August and early September.

Giffard, Beurre Giffard.-Medium size, very fine fruit. Best of its season. Hardy and large yielder. Middle of August.

Rossney.-A new and excellent pear, raised from seed at Salt Lake City, Utah. In size medium to large; very fine grain, flesh meliing and juicy; very sweet. Ripens two weeks after Bartlett. S.

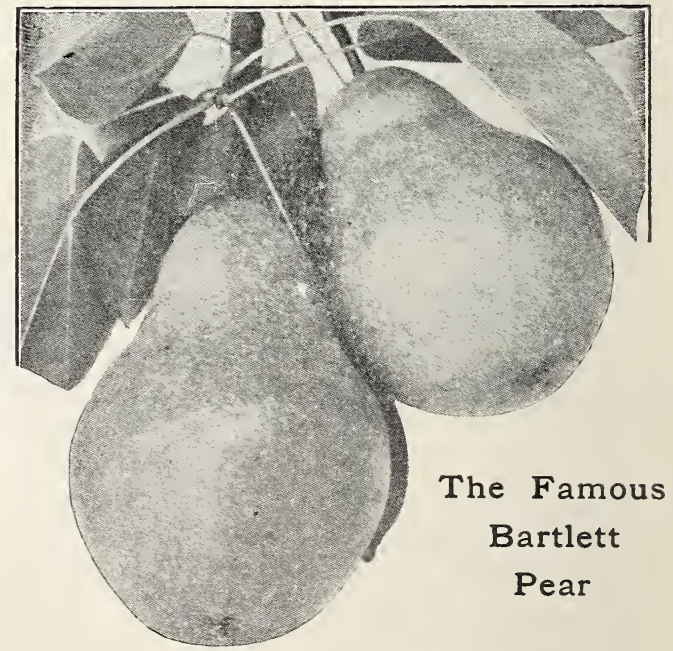

One of the most delicious Pears growa. Brings big prices. 


\section{SUMMER PEARS-Continued}

Souvenir du Congress.-Large, bright yellow and firm to the core. August to September.

Tyson.-Medium size : melting, juicy, sweet, vigorous; bears abundantly. Good Aug. variety.
Wilder.-(Summer)-A valuable early market pear. Regular in form, fair size and very handsome. Greenish yellow color with reddish cheek. Flavor sweet and very pleasant.

\section{AUTUMN}

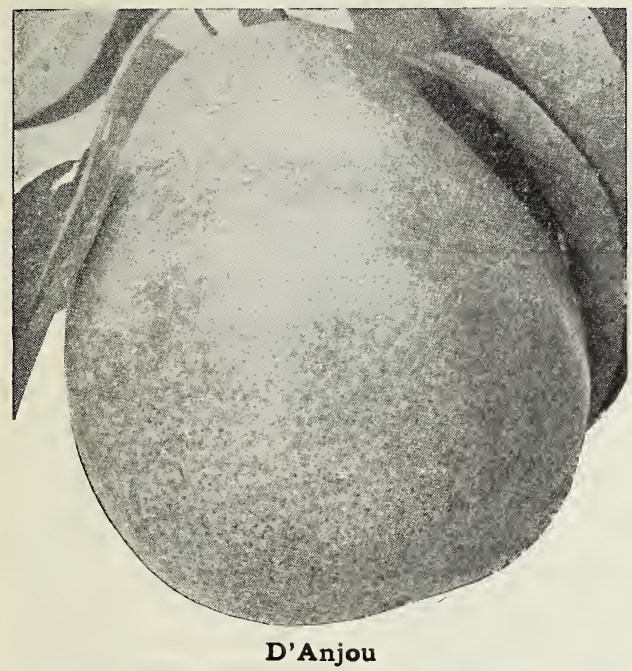

Anjou, Beurre D'Anjou.-A fine market pear, succeeding best on the quince root. Its fine size and melting, buttery texture make it a favorite in all markets for the month of November. Under favorable conditions may be kept till mid-winter. Has some prominence in export market. Tree is strong and productive. Fruit large and yellow at maturity with a very small core. Hard to beat for table or cooking. Season, November.

Bartlett Seckel.-A cross between the Bartlett and the Seckel, combining in itself the richness and high flavor peculiar to these wellknown varieties. Tree hardy, vigorous and productive. Fruit of good size, well colored and handsome.

Belle Lucrative.-(Fondante d'Atonne)-A fine, large pear; yellowish green, slightly russeted; melting and delicious; good grower and productive. One of the best Autumn pears. September and October.

Beurre Clairgeau.-Its large size and beautiful cheek, its excellent shipping and keeping qualities, all combine to make this a profitable variety. Tree is first class in vigor, hardiness and productiveness. Succeeds either as dwarf or standard and bears very early. Fine for eating or cooking, keeps a long time, always sweet and juicy. Season, October and November.
Bosc, Beurre Bosc.-A large russety pear with long neck; melting, high flavored and delicious. Bears well. September to October.

\section{Columbia.-See Bartlett-Seckel.}

Duchesse D'Angouleme.-For years this pear has been counted among the best and most profitable varieties, especially grown on quince stock. Excellent for export, cold storage, and for every use to which a pear can be put. Strong grower, productive, not subject to blight. Fruit large, light green patched with russet, melting, juicy, sweet and good. October and November. Origin, Angers, France, 1812 , chance seedling.

Early Harvest.-(Chambers' or Kentucky)Originated in Maryland, and valued as a profitable early variety. Recommended by the Kentucky Horticultural Society as the best and most profitable market pear of its season. Fruit medium to large; rich, golden-yellow, with red cheek next the sun, thickly covered with gray dots.

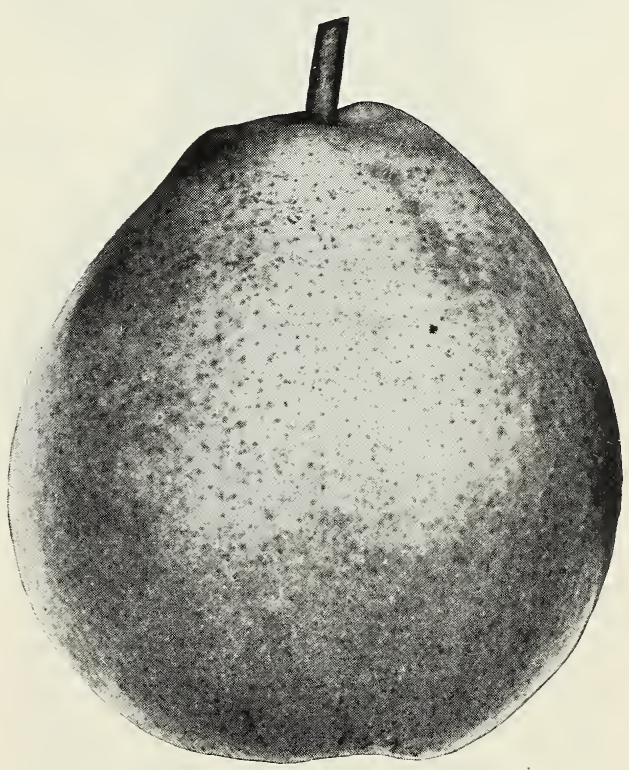

Angouleme 


\section{AUTUMN PEARS-Continued}

Flemish Beauty.-Where this variety succeeds well it is a most popular pear. In some sections it has of late been subject to scab and cracking of the fruit. When well grown the quality is first grade. Large size, light yellow when ripe with patches of brownish red; rich sugary flavor. Tree is first class in hardiness, productiveness and early bearing. Season, September and October.

Howell.-Large, light waxen yellow, with a fine red cheek; handsome, rich, sweet, melting, perfumed, aromatic flavor. Tree an upright, free grower, an early and profuse bearer. Very hardy and valuable. September and October.

Idaho.-Size large, nearly globular, obtusely ribbed; color light, rich, yellow surface, covered with many small dots; cavity very deep and narrow and strongly furrowed, stem small and calyx closed; flesh white, fine grained, buttery, melting and rich. September to October.

Kieffer.-There is perhaps no pear about which a greater diversity of opinion exists. Some fruit men condemn it because of its lack of quality. Others insist that its beau. ty, productiveness and wonderful health make

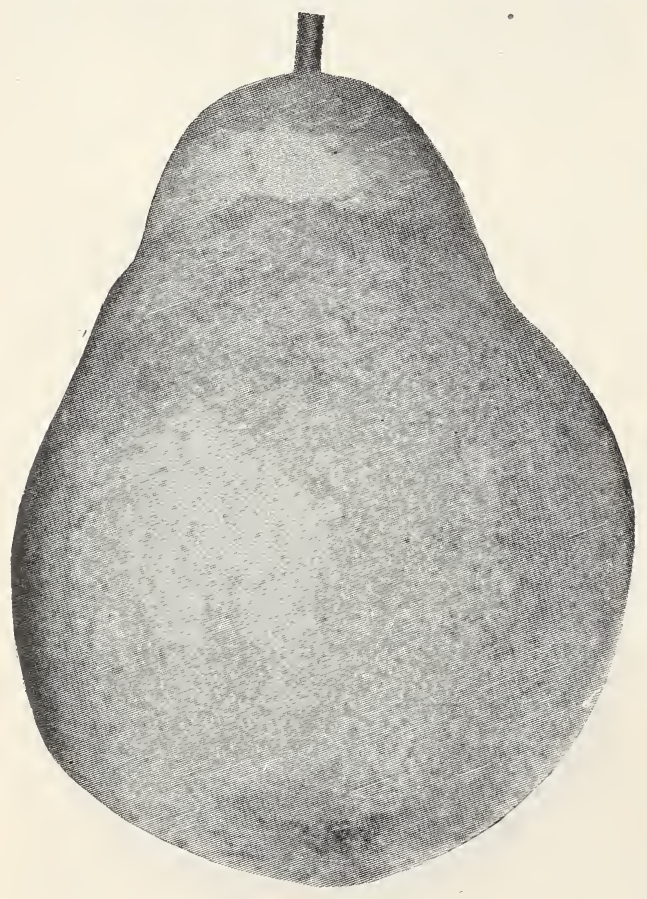

Lawrence it valuable. Tree beats everything for hardiness and cropping. Fruit always large, uniform, golden yellow with bright cheek, not very fine, juicy; flavor moderately sweet but poor for eating. A valuable pear for canning. Will grow almost anywhere. Season, October to January.

Louise Bonne De Jersey.-An excellent export pear if well grown. Succeeds best as a dwarf and equals the Duchess in all respects as a market pear. Tree is an upright grower, vigorous and a great cropper when well cared for and set in deep, loamy soil. The pear is large, yellowish green with red cheek, fine grained and a pieasant aromatic flavor. A fine table pear. Season September and October.

Seckel.-The finest pear in cultivation and should never be omitted from the home gar. den. The richest flavored pear known. Very satisfactory as a dwarf. The small size of the fruit is an objection in some markets, but people are coming to know its excellent quality and the demand is steadily growing. Color brownish green with reddish cheek. Tree is a good grower and bears heavy crops annually. Season, September and October.

Sheldon.-One of the most delicious eating pears. Should be in every home garden. Some growers do not consider it productive enough for a commercial orchard. Tree is vigorous, erect, second rate in productiveness and last to come into bearing. Fruit large, creamy, sweet and aromatic. Thorough fertilizing and cultivation will aid in making this a profitable variety. Season, October and November.

Vermont Beauty.-A most desirable pear. The fruit is of medium size, very handsome, being yellow with a bright carmine cheek. The flesh is rich, juicy, aromatic, of the best, and almost equal to the Seckel; ripens immediately after the Seckel.

Worden Seckel.-Originated in Oswego County, N. Y. It is a seedling of the Seckel, and is equally as good in quality as that variety and more juicy, with an aroma equally as rich and inviting, while in size, color, form and appearance it is decidedly superior. The color is yellow, with light red on the sunny side. The tree is very hardy and an enormous bearer, and the fruit is ripe just after the Seckel. All lovers of good pears should have trees of this variety. 


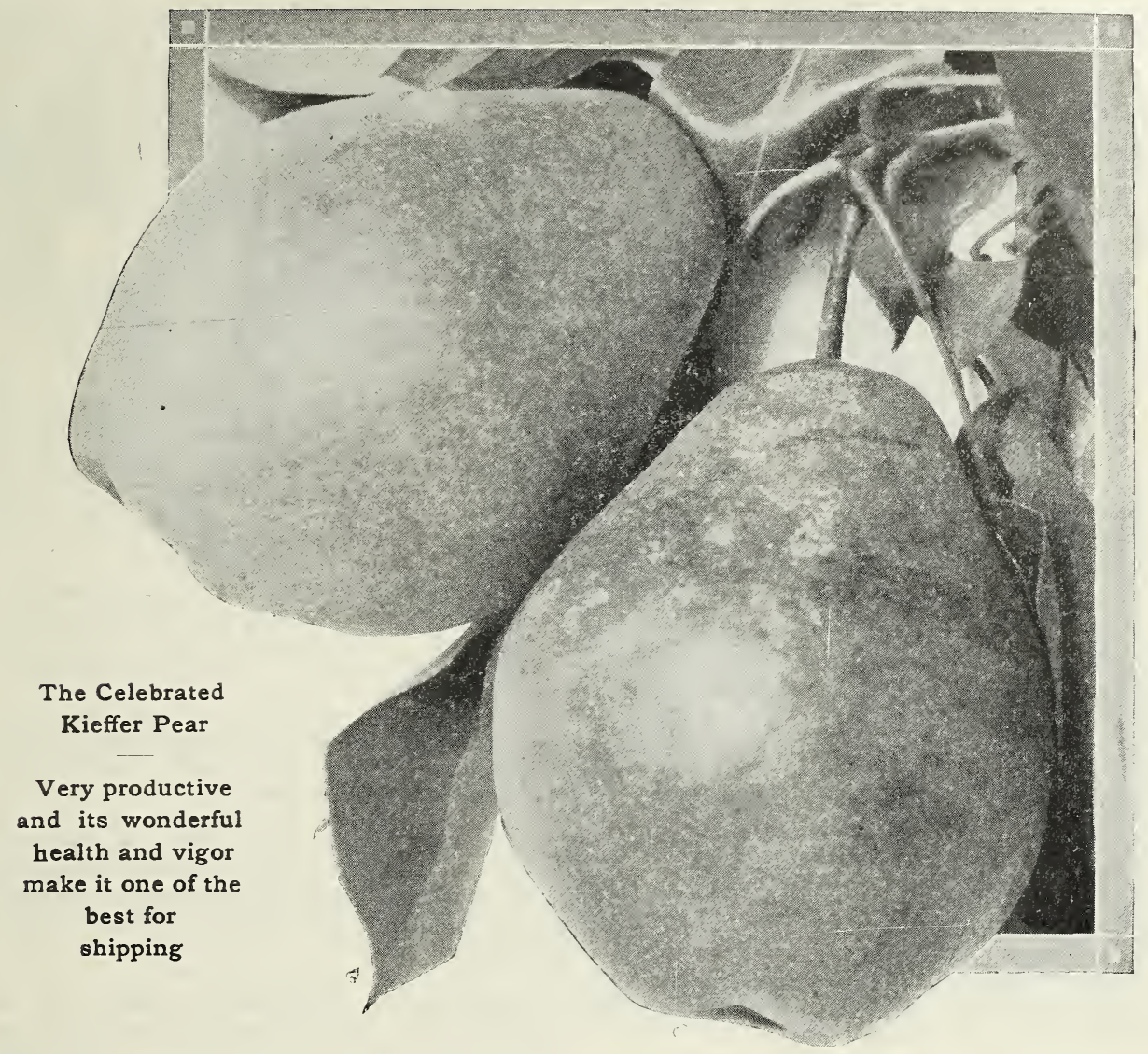

\section{WINTER}

Easter Beurre.-Large; pale yellow, sprinkled with round dots, often dull red cheek; quality good. One of the best winter pears. Keeps all winter. Best on quince.

Lawrence.-Probably the best dessert pear for use in early winter. Fruit is fair size, Jellow with numerous small dots, juicy, sweet and very excellent for either cooking or eating out of hand. Tree is one of our hardiest, a moderate grower, early bearer and fairly productive. Season, December.

Lincoln Coreless.-A remarkable late winter pear, from Tennessee. Keeps well until middle of March; very large, handsome appearance, good quality, and with but few if any seeds. This pear is distinguished for its very small amount of core and seed, some specimens being almost entirely without either. Color golden yellow. Tree a good grower and very productive.
Mount Vernon.-Medium to large; of rich, russet color; flesh juicy, rich, melting, with a spicy flavor. November to January.

President Drouard.-A very good looking and large winter pear with a delicate and abundant perfume. Has a creamy flesh that is sweet and unusually good. The tree grows vigorously; succeeds well as a dwarf. Season. March to May.

Winter Nelis.-An old variety of excellent quality which has long been a favorite winter pear. Scarcely large enough for the commercial orchard. unless a special market can be made for it where the high quality will be appreciated. Tree a spreading, stocky grower (should be top worked), bears early and abundantly. Fruit small, dull green, fine grained, richly flavored, sugary and aromatic. A fine coooking pear. Season December. 


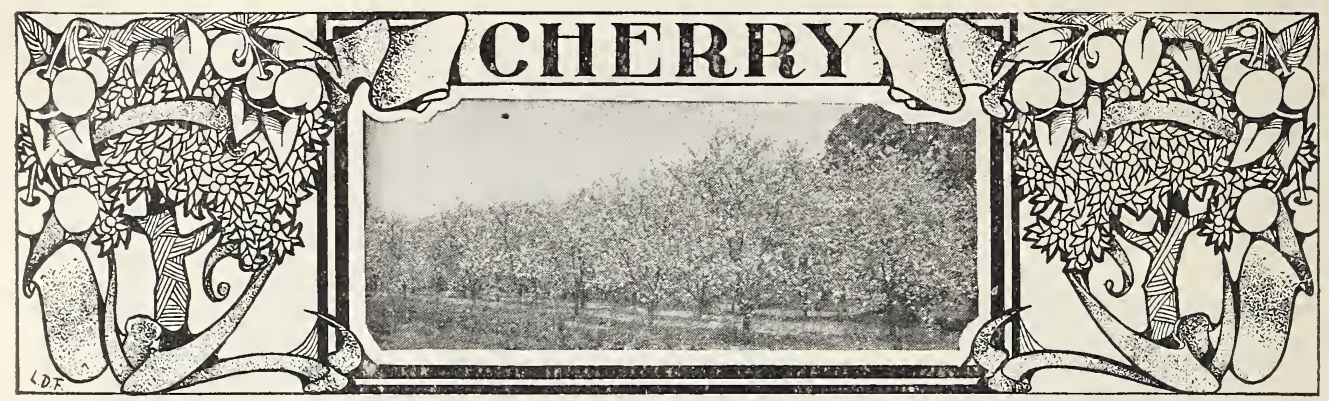

THERE are not many more desirable trees than the Cherry.. It can be 1 planted near the street along fence lines, avenues and many places where other fruit would not be prolific. Cherries always find a ready market at a profitable price. The trees thrive in any well drained soil. The Duke and Morello, or acid varieties, are hardy, while the Hearts and Bigarreaus, or sweet sorts, will resist cold weather and can be grown in most places.

A two-year-old Cherry tree will bear four quarts of fruit. A ten-year-old tree will produce from 100 to 300 pounds. An acre of Cherry trees well taken care of will produce 100 to 150 pounds to the tree or 6 to 9 tons to the acre. Six tons at 7 cents per pound would bring $\$ 980.00$.

Cherries are divided into two classes, sweet and sour; sweets being called Hearts and Big. arreaus, the sours Dukes and Morellos. The sweets attain a larger size than the sours but are not as hardy and are more likely to be injured by bursting of the bark.

\section{HEART and BIGARREAU CHERRIES}

[Fruit heart shaped, with tender, sweet flesh. Tree of rapid growth, with large droop. ing limbs with abundance of foliage].

Black Tartarian.-Large, purplish black, half tender, flesh firm, mild and pleasant. A large producer. Last of June to July.

Bing.-This is one of the most delicious Sweet Cherries that you can grow. The tree is very hardy and vigorous and has heavy foliage. It succeeds in the East better than most sweets. Fruit is large, dark brown or black and of very fine quality. Bing is a good shipper and should be planted with Lam. bert for commercial purposes.

Black Eagle.-Large, black; very tender, juicy, rich and high flavored; vigorous grower and productive. First to fifteenth of July.

Centennial.-A new white Cherry and should be planted by everyone.

Coe's Transparent.-Medium size; pale am. ber, red in the sun; tender, juicy, rich, handsome; one of the best; strong grower; productive. Last of June.

Governor Wood.-Very large, rich; light yellow, with red cheek; juicy and sweet. One of the very best. Last of June.

Knight's Early Black.-Large; black, tender, juicy, rich and excellent; good grower and productive. Middle to last of June.
Luelling.-(Black Republican)-A native of Oregon. Fruit very large, shining black; flesh very solid and firm; fine; a good keeper, and will bear transportation well. Tree a moderate grower and rather tender; an early and profuse bearer.

Napoleon.-A magnificent cherry of the largest size; pale yellow, with a bright red cheek; very firm, juicy and sweet. Bears enormous crops; ripens late; valuable for canning.

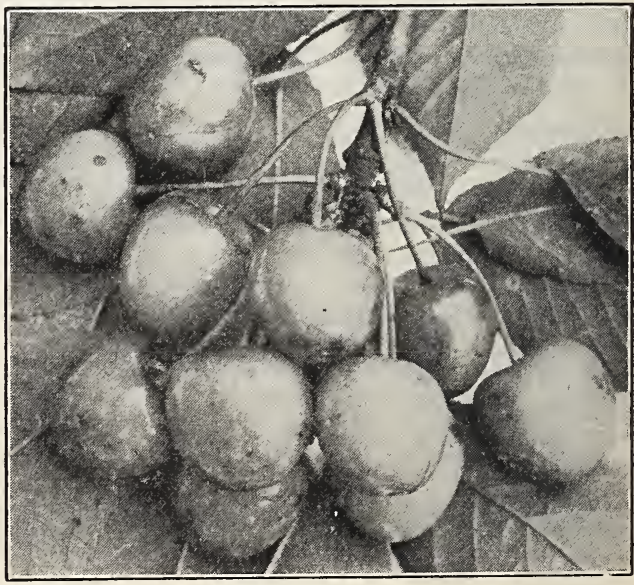

Napoleon 
Rockport Bigarreau.-Large; pale amber. with clear red; a very excellent and handsome cherry; good grower and bearer. Last of June.

Schmidt's Bigarreau.-A most promising cherry; fruit of immense size, of rich, deep black; flesh dark, tender, very juicy, with a fine flavor; bears abundantly and makes a most noble dish for the table.

\section{DUKE AND MORELLO CHERRIES}

$\mathrm{T}$ HESE, for the most part, are round-headed; fruit generally acid, though some varieties have a very rich, pleasant flavor. The trees are naturally of a smaller growth than the preceding class and well adapted for dwarfs or Pyramids. The Morellos are more slender and spreading in habit than the Dukes, which are of stocky, upright growth. Both are more hardy than the Hearts and Bigarreaus, and in large demand where the latter cannot be grown to advantage.

Baldwin.-Tree, upright, vigorous grower, forming round head; leaves large, broad; fruit large, almost round, very dark, transparent wine color; flavor slightly acid, yet the sweetest and richest of the Morello type.

Compass.-Originated at Springfield, Minn. It is a cross between the Sand Cherry and the Minor Plum. Fruit nearly an inch in diameter, a bright red, sweet, juicy, fine flavor. Tree $a b$ solutely hardy in that severe climate.

Dyehouse.-One of the best Sour Cherries for market or home use. It is larger, finer, of better quality and has a smaller pit than Early Richmond. The tree is hardy, is an upright grower and always productive. The great quality of this variety is its tendency to hang on the tree after it is ripe.

Early Richmond.-One of the most popular of all the acid Cherries. It cannot be surpassed for hardiness or for cooking purposes. The fruit is of medium size, round and dark red. The flesh is tender, juicy and sub-acid. The tree is a wonderful bearer. Fruit ripens in June.

English Morello.-Medium sized Cherry of a very dark red color, sometimes nearly black. It is very acid in flavor, the flesh is of good quality and it makes a fine canner. Tree is a small grower with light limbs and trunk. Ripens in July.

Empress Eugenie.-Fruit large, dark red, very rich, tender and sub-acid. Tree heads very low. Ripe about July lst.

Late Duke.-Large, light red, late and fine. Last of July.

Louis Phillippe.-A large dark red Cherry; flesh is tender and mildly acid. Ripens middle of July.

May Duke.-Large, red, juicy and rich; an old excellent variety; vigorous and productive. Middle of June.

Montmorency.-This is the best of all the sour varieties of Cherries. There is a greater demand on the market for this Cherry than for any other. The trees are the cleanest and best growers and are less subject to disease, less affected by wet weather, and are the best bearers of the best fruit of all other sour varieties. No matter how unfavorable the season may be, Montmorency can be depended upon
Windsor.-A seedling originated at Windsor, Canada, and a fine variety, too. Fruit large, liver-colored; flesh remarkably firm and of good quality. A very valuable late variety for market and for family use. Middle of July.

Xellow Spanish.-Large, pale yellow, with red cheek; firm, juicy and excellent; one of the best light colored cherries; vigorous and productive. Last of June.

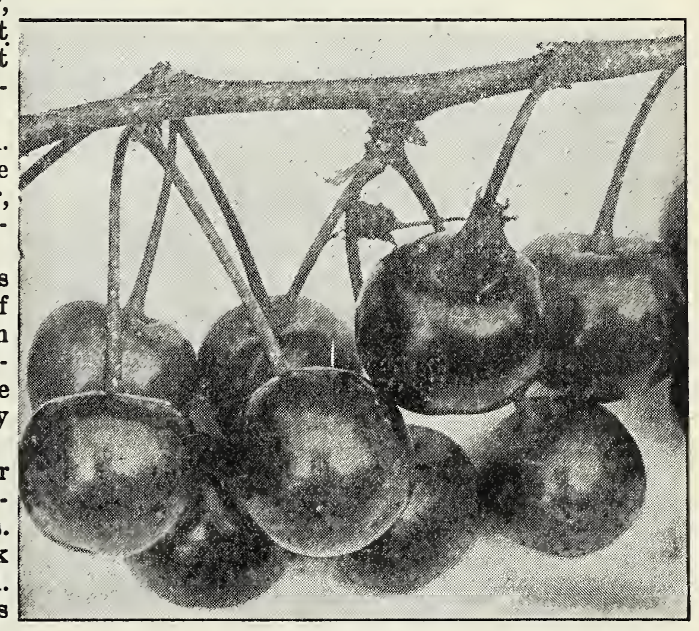

Montmorency

for a full crop. The Montmorency is a good shipper, very attractive looking and always brings good prices. The canning factories are always calling for them and want them by the hundreds of tons. The fruit is good sized, fine flavored and bright, clear shining red. The flesh is of fine quality and sub-acid. Fruit ripens 10 days after Early Richmond.

Ostheime.-This variety is known as the "Russian Cherry" as it was imported from St. Petersburg, Russia, and has been tested in the severest winters of Minnesota and found to be perfectly hardy. The fruit is large and roundish. Flesh is liver colored, tender, juicy and almost sweet, although a sub-acid Cherry. Quality is fine Ripens the middle of July.

Olivet.-A new Duke of French origin. Un. like most others of this class, it is said to be very early and to ripen over a long period. Fruit very large, globular, and of a deep shin-. ing red.

Reine Hortense.-Very fine, large, bright red, juicy and delicious, vigorous and productive.

Wragg.-Fruit large, bright red, translucent; stalk long; flesh firm, rich, sweet, excellent. 


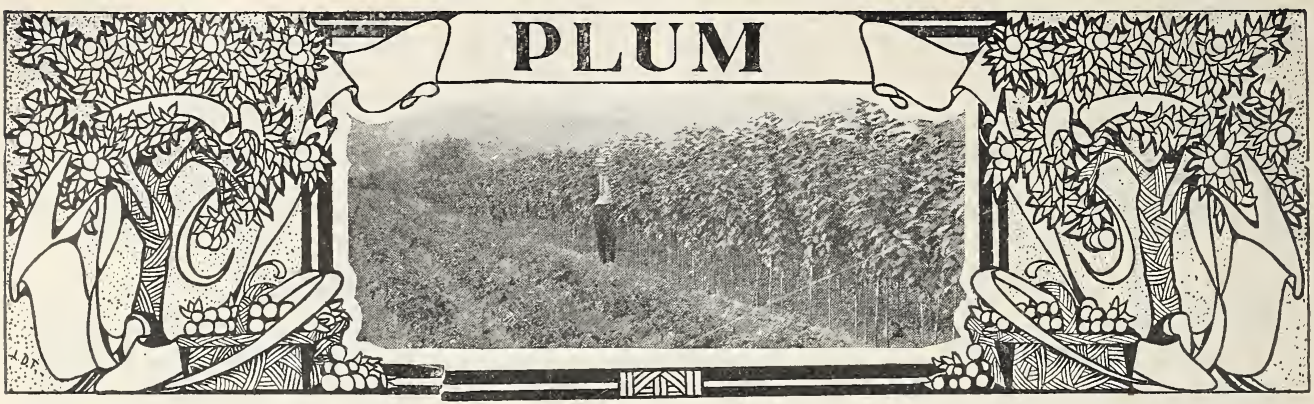

THE Plum does best on a clay soil, dry and well drained. It grows the most thriftily and with cultivation suffers least from "Curculio" or "Black Knot." There is little trouble in keeping the trees free from insects and disease. After the blossoms have fallen spread a sheet on the ground under the tree. Then jar the tree so as to shake down the stung fruit and insects. These should be burned. This should be done every day for a week or more and it is important that it is done early in the morning.

AMERICAN SORTS.

Aikin. - (Nigra) - Found wild in Atkin County, Minnesota, (near Lake Itasca) and introduced by The Jewell Nursery Co. in 1896. Has the most northern origin of any commercial plum and is also one of the very earliest to ripen, fully two weeks before DeSoto. Fruit large greenish yellow, ground covered with brilliant red turning to dark red when ripe. Flesh, yellow, rich, tender.

Cheney.-(Nigra) - Fruit irregular, oval, medium to large; color a dark and rather dull red with slight blue bloom, skin thick; flesh yellow and firm; stone large, pointed, oval, much flattened, cling. Season early. Tree a fine, vigorous, upright grower with large ornamental flowers.

De Soto.-(Americana)-Probably the most grown of any plum of the American group. Found wild on the Mississippi at DeSoto, Wisconsin and introduced in 1863 by Elisha Hall. Quality unsurpassed and productiveness almost too great; tree should be well fed and the crop thinned to prevent overbearing and improve size of fruit. Season medium. Fruit, medium; orange overlaid with crimson; flesh yellow and firm; of fine flavor and quality.

Forest Garden.-Fruit large, nearly round, dull purplish red with thin bloom; flesh yellow, sometimes reddish next the stone; firm, sweet and of pleasant flavor; cling. Season medium. One of the most extensively grown varieties in Northwestern orchards and generally reported as a profitable sort.

Hawkeye.-This variety originated in Iowa and is perfectly hardy in any part of the United States or Canada. It is a wonderful bearer and of fine quality.

Pottawattamie. - Yellow, overspread with bright pink and prominent white dot; flesh yellow, sweet and good. Perfectly hardy and an immense, early and annual bearer. July.
Surprise-_Hortulana)-A variety introduced about 1899 by Mr. Martin Penning of Sleepy Eye, Minn., and it is said by many to be the finest in quality of any of the cultivated varieties in the native Minor group, also the hardiest of that type. Fruit large to very large; skin medium, thick, tender; bright red; flesh pale yellow, meaty and of fine flavor; quality extra good. Season medium. Tree an upright, vigorous, healthy grower and is everywhere reported very productive.

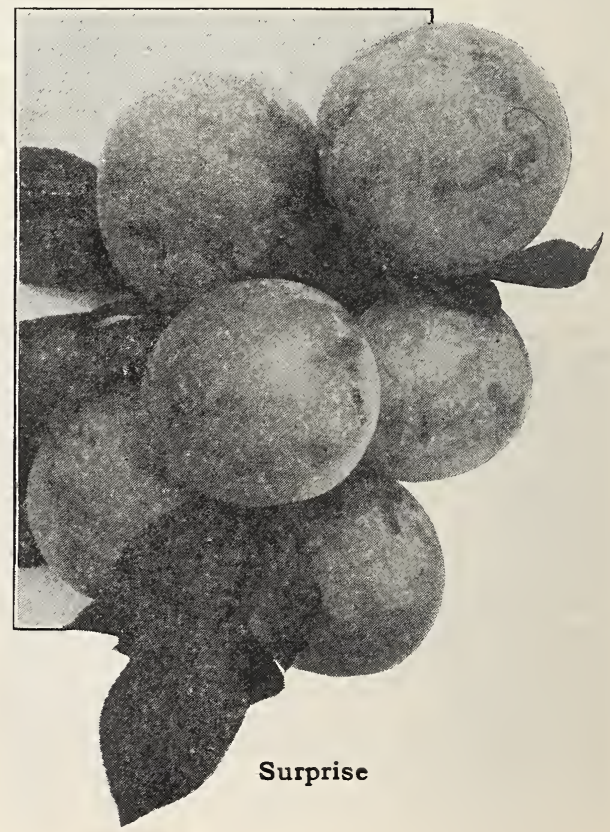


Weaver.-This remarkable plum was found near Cedar Rapids, Iowa, growing on the old Indian camping ground. Flesh firm, with fla. vor resembling the apricot. As a substitute for the peach it has no rival. Curculio proof.

Wild Goose.-An improved variety of the Chickasaw, evident in the great vigor of the tree and increased size of the fruit which is nearly as large as the Green Gage. Skin purple, with a bloom; flesh juicy, sweet and adheres to the stone. Last of July.

Wolf.-This is an enormous bearer and bears annually. Fruit large and of good quality; color bright red. Splendid for eating.

Wyant. - (Americana) - Fruit medium to large, slightly oblong; color purplish-red, inclining to orange on shaded side; stone semicling; skin thick; flesh rich yellow sometimes red next the stone; quality good, and variable being sometimes quite astringent. Tree is a spreading grower and is reported very prolific.

\section{EUROPEAN SORTS}

Beauty of Naples.-A new variety of the highest promise; size large, color greenish yellow, flesh firm, juicy and very fine flavored; tree very hardy and prolific. Middle of September.

Bradshaw.-Very large and fine; early; dark violet red; juicy and good. Very productive; valuable for market.

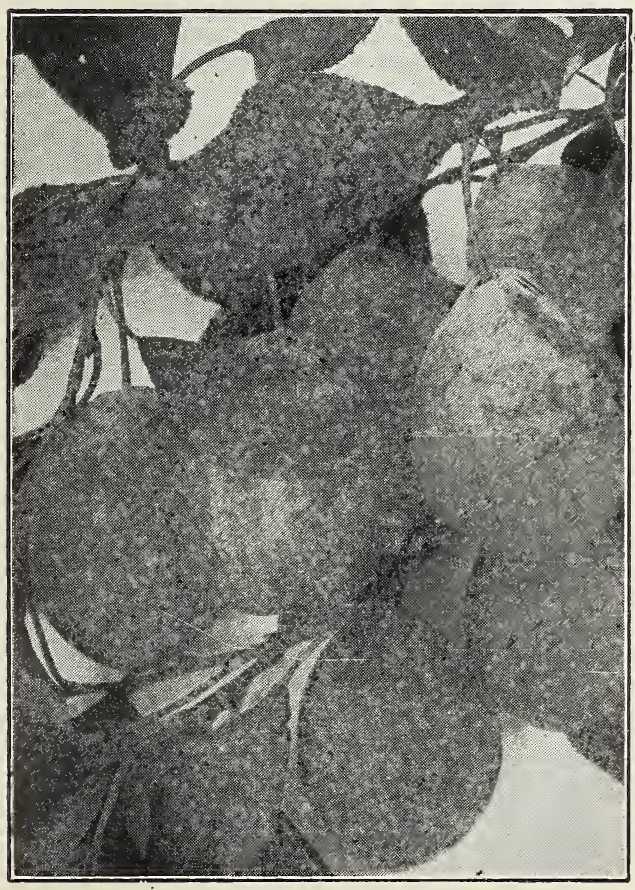

Guii

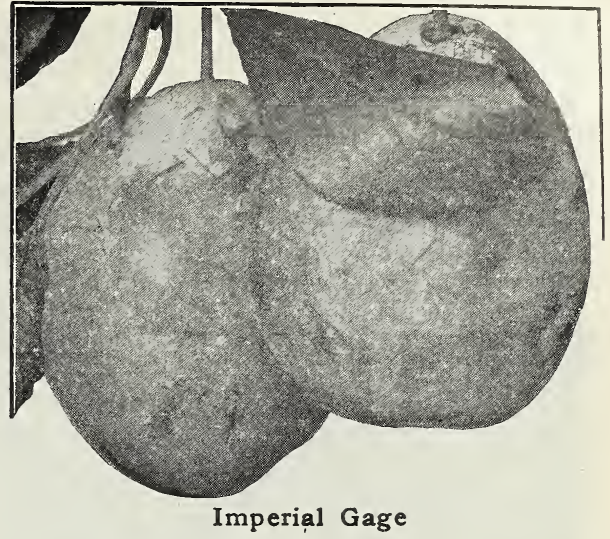

Coe's Golden Drop.-Large and handsome, oval; light yellow; flesh firm, rich and sweet; adheres to the stone. Last of September.

Fellemberg.-(French or Italian Prune).Large, oval; purple; juicy and delicious; parts from the stone; fine for drying. September.

German Prune.-Medium; oval; purple or blue; juicy, rich, fine. Very productive. September.

Grand Duke.-As large as the Bradshaw, of same color, and ripening latter part of September. Entirely free from rot.

Green Gage.-Small; considered the standard of excellence, slow grower. Miadle of August.

Guii.-Extensively grown for market, having proved to be one of the most profitable for that purpose. Tree a hardy, very strong, vigorous upright grower, spreading with age and bear. ing; an early and abundant bearer. Fruit large, roundish, oval. Skin dark purple, covered with a thick blue bloom; flesh pale yellow, a little coarse, rather firm, juicy, sweet, sprightly, sub-acid; freestoone. Season last of August and first of September.

Imperial Gage.-Large; oval; greenish; juicy, rich and delicious; parts from the stone. Very productive and one of the best. Middle of $\mathrm{Au}$ gust.

Lincoln.-This is said to be one of the most remarkable plums yet introduced. The largest of all the hardy varieties, specimens of the fruit weighing as much as four ounces each; it is of the finest quality, even surpassing its parent, the Green Gage.

Lombard.-Medium size; oval; violet red; flesh yellow, juicy and pleasant. Tree a great bearer, well adapted to light soils. Very hardy. September.

Monarch.-Very large, roundish oval; dark purplish blue; freestone; excellent. An abundant bearer.

Moore's Arctic.-Size medium or below; skin purplish black, with a thin blue bloom; flesh greenish yellow. juicy, sweet and pleasant flavor. Charles Downing speaks of it as follows: "A new, hardy plum, whirh originated in the highlands of Aroostook County, Maine. 


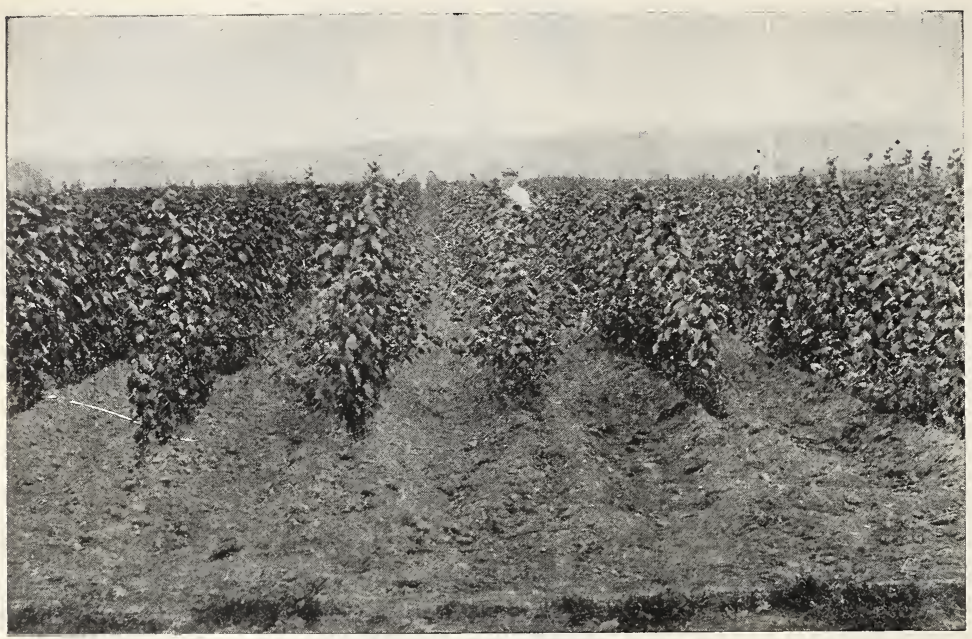

Block of Lombard Plum Trees

juicy, sweet and good. Productive. One of the best. End of August.

Yeliow Egg-A very 1 a rge and beautiful egg-shaped yel1ow plum; a little coarse, but excellent for cooking. Very productive. End of August.

\section{JAPAN VARIETIES OF PLUMS}

Abundance - Large and beautiful; amber, turning to a rich, bright cherry; flesh light yellow, juicy, tender, sweet, exceedingly productive. Season very early.

Niagara.-A vigorous, productive variety; valuable both for dessert and cooking; fruit large and handsome, remaining well on the tree; flesh juicy, rich and fine flavored. Last of August.

Pond's Seedling.-(Hungarian Prune)-A magnificent English plum; light red, changing to violet; flesh rather coarse. Tree a good grower and an abundant bearer. One of the most attractive trees in cultivation.

Reine Claude-(Bavay's Green Gage)-Large, greenish yellow, spotted with red; firm, juicy, sugary, and of fine quality; very productive. September.

Shipper's Pride.-The fruit is of large size, it being no uncommon occurrence to find specimens measuring two inches in diameter each way, as it is nearly round; it is what Mr. Charles Downing calls a semi-cling, of a handsome, dark purple color; excellent for canning and an unusually good shipper,

Shropshire Damsor.-A medium sized, dark purple variety; esteemed. for preserving. Very productive. October.

Tennant Prune.-Originated in Oregon. New and very promising on the Pacific Slope. If it does equally well at the East it will equal or surpass in all respects our largest and best prunes.

Turkish Prune.-The largest and decidedly the best of the prune family and very like the Italian prune in most respects. Splendid for drying, canning or using fresh.

Washington.-A magnificent large plum; roundish; green, usually marked with red;
Burbank.-Large and beautiful; clear cherry red; an abundant bearer; valuable market variety. Ripens early in September.

October Purple.-One of Luther Burbank's Hybrids and considered by him one of his best. Large, purple, yellow flesh; very late.

Red June.-Medium to large, roundish, conical, purplish red, handsome; flesh yellow, quality good. Valued for market on account of its earliness.

Wickson.-Very large, glowing carmine, with a heavy white bloom; flesh firm, sugary, delicious; stone small.

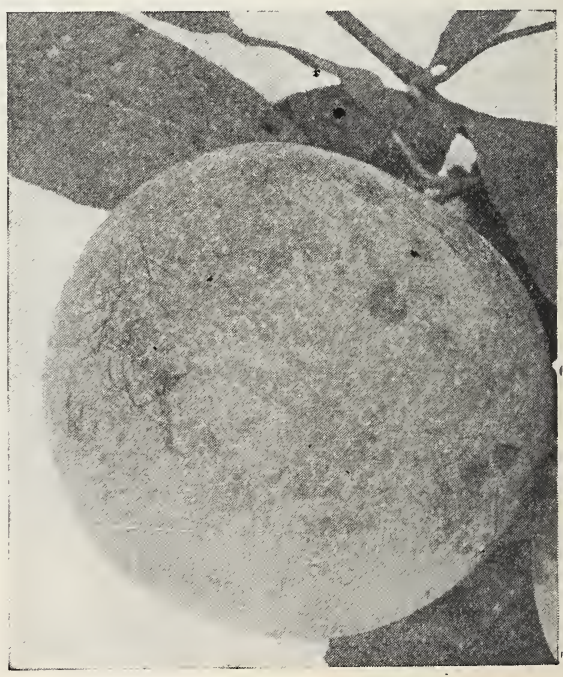

October Purple 


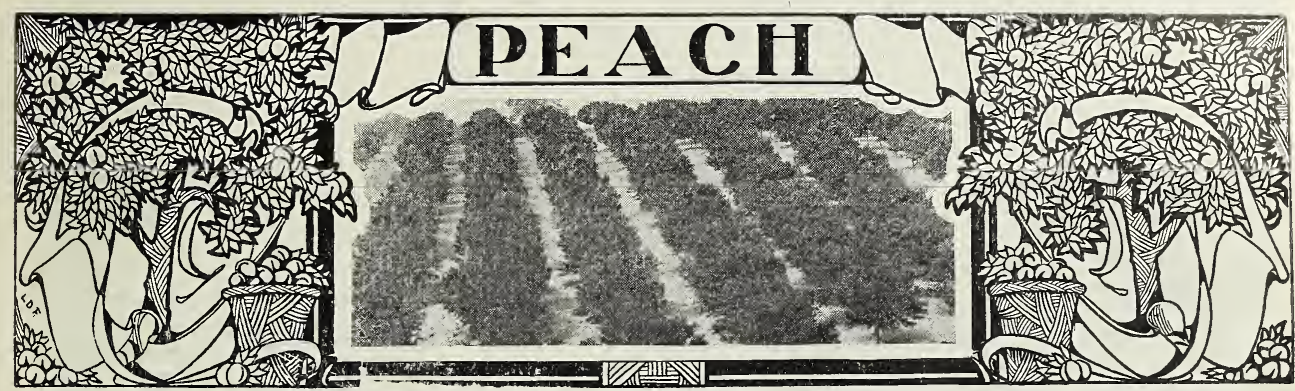

DEACH growing is today a great industry. The ease with which these trees may be cultivated, their freedom from disease, the short period before they become productive, together with the immense demand for the fruit and the facility with which it may be shipped to markets, make Peach growing extremely profitable.

To secure healthy, vigorous and fruitful trees the ground must be kept clean and mellow, and should receive an occasional dressing of wood ashes.

To keep the trees in good shape it is necessary that they should be pruned yearly, all the dead and useless wood cut out and light and air let in.

Admiral Dewey.-This is another triumph in the production of very early peaches; there is no knoown variety that can compare with it in all the qualities that go to make a desirable early market variety. Perfect freestone.

Alexander's Early.-(Alexander)-Originated near Mt. Pulaski, Ill. Medium size greenish white, nearly covered with rich red; flesh melting, juicy, sweet; tree vigorous and productive; ripens two weeks earlier than Hale's Early.

Amsden's . June--(Amsden)-Originated at Carthage, Mo., in 1882. Medium size, skin greenish white, nearly covered with purple in the sun; ripens with the Alexander and closely resembles that variety, but some think it a little higher flavor.

Barnard's Early.-A fine yellow peach of good quality; very popular in Michigan. An excellent canner.

Beer's Smock.-Large to very large; yellow, with red cheek; flesh yellow and of the very best quality for the season; freestone; a reg. ular and enormous yielder.

Belle of Georgia.-A very large, white fleshed peach of excellent flavor. Pit free. Skin is white with a red cheek. Tree is a rapid grower and very productive. A very showy peach when displayed for market. Ripens with Crawford Early. Sept 1st to 5th.

Bokara, No. 3-Seventy-five per cent hardier than any other peach. Imported by Professor Budd, from Bokara.

Chinese Cling.-This type has of late years produced several improved seedlings, which, although not all attaining the enormous size of the original variety, are, however, of better flavor and less predisposed to decay, and of less straggling habit of growth.
Carman.-A moderately early white fleshed variety said to be absolutely rot-proof. Fruit is large, round, pale yellow color with red cheek. Freestone. Tree is extremely hardy. August.

Chair's Choice.-A very large deep yellow peach with red cheek. Has yellow flesh that is firm and of fine flavor. Pit is perfectly free. Tree is a strong grower and good bearer. Ripens just before Smock. October.

Champion.-This variety may be classed as the best dessert peach of its season. White fleshed, sweet and delicious, but a little tender for distant shipping. The fruit grows very large, specimens often measuring ten inches in circumference. Tree is very hardy and productive; has stood 18 degrees below zero and produced a full crop the following sum. mer. Freestone and ripens last of August. Originated in Illinois.

Crawford's Early.-Early Crawford has long held its place at the head of the list of peaches for home use or market. A magnificent, large yellow fruit of good quality. No other variety has been so widely planted for market purposes. Yellow flesh, free pit, sweet and luscious. Tree vigorous and productive. Fruit ripens first of September. Origin, Middle town, N. J., by Wm. Crawford.

Crawford's Late.-A fine late September variety. Fruit is large and yellow with a flavor possibly not quite equal to Early Crawford. Still the peach has a big demand and is largely planted as a profitable market sort. Tree is vigorous; only fairly productive. Valued as first class in all markets. Origin, New Jersey. 


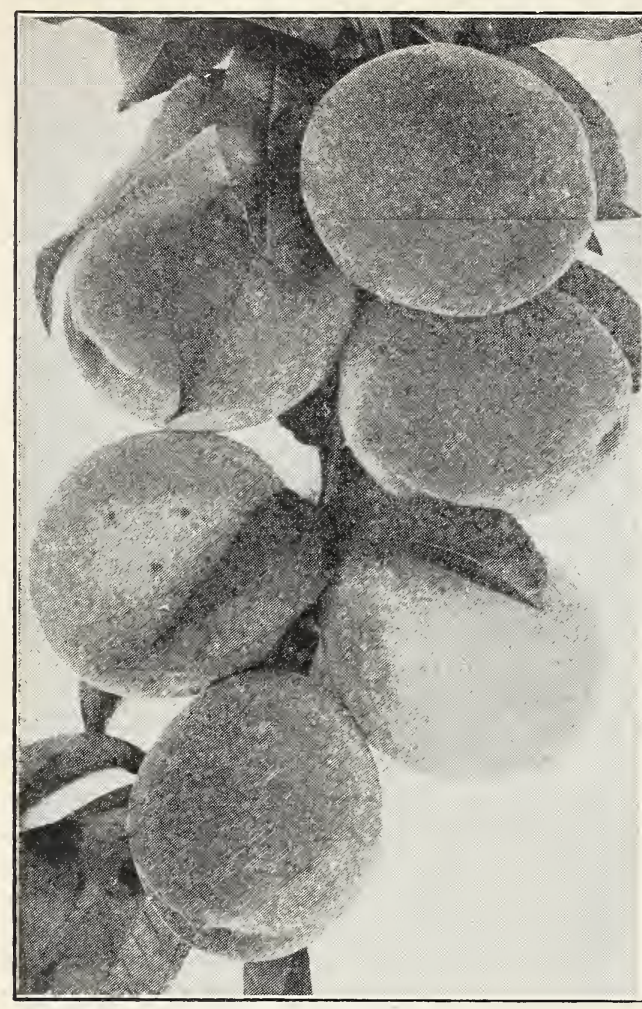

Elberta Peach

Crosby.-A peach of good quality which was once extensively planted. Requires intensive cultivation to reach good marketable size. At its best the fruit is first class in every respect. Fine grained, tender, sweet and very agreeable. Freestone. Tree is vigorous, healthy, fairly hardy and very productive. Ready middle of September. Origin, Massachusetts, 1876.

Elberta.-The best peach of its season for all markets as it has grand shipping qualities. Probably the greatest commercial peach on the market today. The fruit is large, yellow with red cheek, juicy and highly flavored. Flesh is yellow and fine. Pit perfectly free. Tree is vigorous, hardy and a good uniform cropper. Ripens about ten days later than Early Crawford, late September. Origin, Georgia; cross between Chinese Cling and Early Crawford.

Early Rivers.-Large; color creamy white, with a delicate pink cheek; flesh melting, with a remarkable rich flavor. Larger and ten days later than Alexander. One of the finest of all peaches for home use or near-by market.

Early York.-Medium size, greenish white, covered in the sun with dull red; flesh greenish white, very tender.
Fitzgerald.-This is one of the hardiest varieties of peaches, and the quality resembles Early Crawford. A little finer for eating and the season is a little later. Fruit runs medium to large, has jellow flesh with an excellent flavor. Freestone. A very early bearer. Extra hardy, succeeding in Canada and in Michigan perfectly. A very high class home market peach. Origin, in the garden of Mr. Fitzgerald, Oakville, Ont., about 1895.

Foster.-Originated in Medford, Mass. Large, deep orange red, becoming very dark red on the sunny side; flesh yellow, very rich and juicy, with sub-acid flavor. Ripens with Early Crawford. Very handsome.

Globe.-A rapid, vigorous grower and enormous bearer; fruit very large, globular in form; flesh firm, juicy, yellow, shaded with reddish crimson towards the pit or stone; quality good; very rich and luscious. September and October.

Gold Drop.-Large, golden yellow, with red cheek in the sun; flesh, yellow, juicy, rich and very good. Tree very hardy, productive. Ripens between Hill's Chili and Smock.

Greensboro.-The largest and most beautifully colored of all the early peaches. Of good quality; juicy; a freestone, but adheres slightly; ripens perfectly to the seed, and with the Alexander. which makes it of great value as a market peach.

Hill's Chili.-Recommended for drying, a good shipper. Tree is fairly vigorous and a big cropper, making it a profitable variety when grown for evaporators. It is a good cooking fruit, large, yellow, tinted with red and yellow, sour flesh. Considered second class as a regular market sort. Mid September. Origin, New York State.

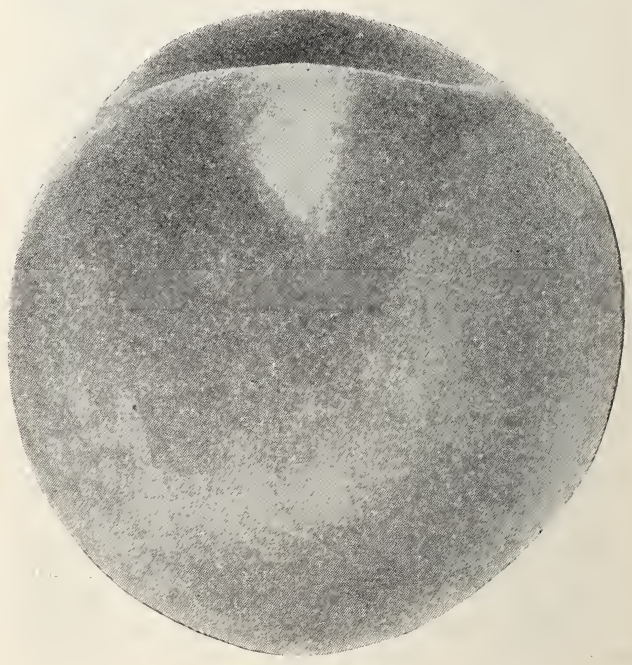

Crawford's Early 


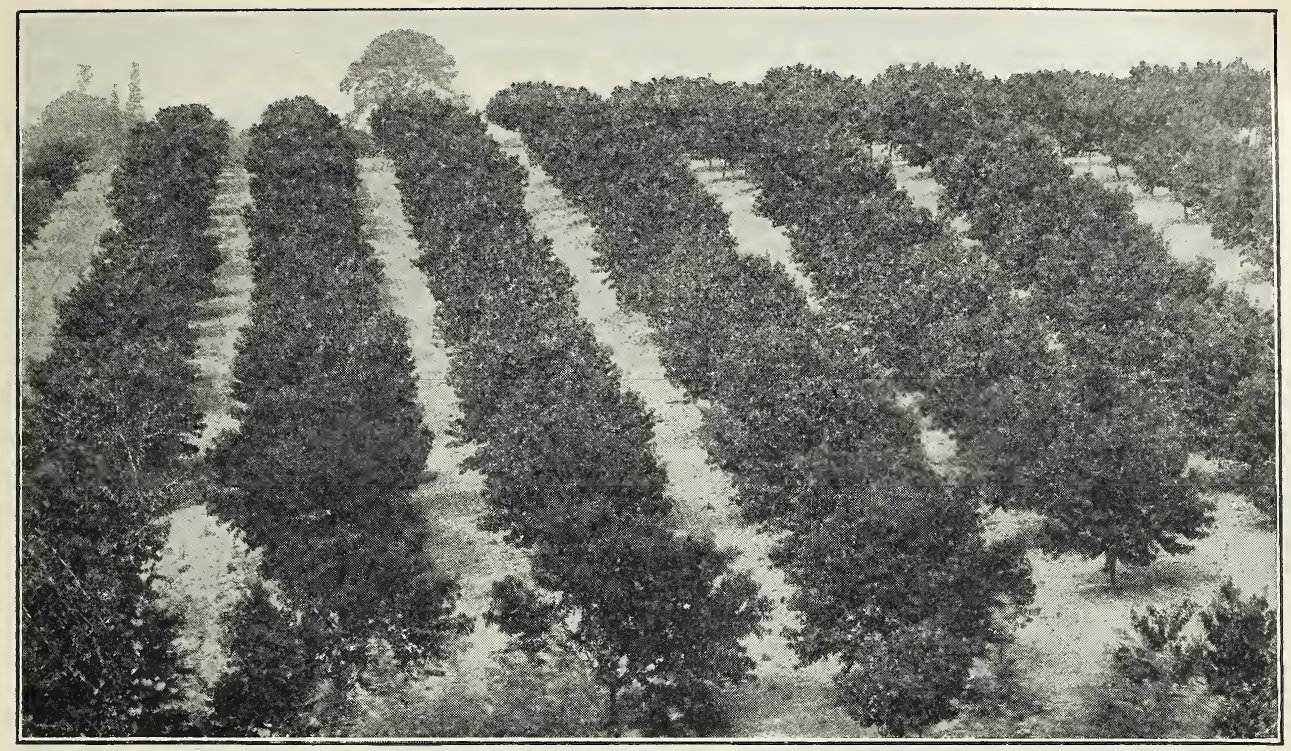

\section{A Corner of an Elberta Orchard that Made Its Owner Rich}

Heath Cling.-(White Heath Cling)-Originated in Maryland, where it is much esteemed. Of large size and good flavor.

Kalamazo0.-A popular market peach in Michigan; inferior to Elberta but a heavier cropper. Grows to medium size, color yellow with red cheek, freestone, yellow flesh, moderately tender and juicy, flavor fairly sweet. A good cooking fruit. Valued for nearby markets, but is smaller than Elberta so that it hardly sells with that large showy variety. Late September. Origin, Michigan.

Lemon Free.-A new seedling, originated in Ohio; resembles somewhat the Smock Free, but it is in every way finer, larger and of better quality; a regular and prolific bearer, with fruit sometimes measuring 12 inches in cir. cumference, and of finest color and flavor. Ripens first of October. Freestone.

Mayflower.-Earliest peach known. Ripens one week before Sneed; color red all over, beautiful appearance. Carries well to market, not being tender like Sneed. Blooms very late, crop never entirely cut off by late frosts, size medium, quality good. Tree in upright, good grower, a very prolific bearer. Originated in Copiah Co., Miss.

Mountain Rose.-A favorite in New Jersey where it ripens early and grows to large size for so early a peach. A reliable cropper. Color white with carmine cheek, inside creamy white, abounding in rich, sweet juice. Considered first quality for dessert. Early August. Origin, New Jersey.

Niagara.-A very large, yellow peach and a very popular one, especially in Niagara County, N. Y., where it originated. Bears a very close resemblance to Elberta, but is larger and finer in every way and ripens one week earlier than
Elberta. The fruit is lightly flavored and luscious. Tree is vigorous, healthy, being seldom affected with leaf curl, and a productive, regular bearer. In many orchards in $\mathrm{New}$ York State it has borne regular crops of perfect fruit for the past seven years. Season, september first.

Old Mixon Free.-A white fleshed peach with a red cheek presenting a good appearance in the basket. Flesh rather tender for shipping, hence not so much planted as formerly. It is a delicious peach for eating out of hand, and just as good for cooking or canning. Good size, free pit. Tree is vigorous, spreading and moderately productive. Early September.

old Mixon Cling.-Large, pale yellow, with red cheek; juicy, rich and high flavored; one of the best clingstone peaches. Last of September.

Rochester.-Has the habits and characteristics of the Crawford, but fully two weeks earlier. Yellow, freestone, good size, very sweet and fine flavor. Require only half the usual amount of sugar for canning. Do not rot on the trees. Since its introduction this splendid variety has brought each season from $20 \mathrm{c}$ to $30 \mathrm{c}$ a basket more than the prevailing market price. In a class by itself. Controlled exclusively by us. Stock limited.

Salway.-Fruit large, roundish, deep yellow, with a rich marbled, brownish red cheek; flesh yellow, firm, juicy, rich and sugary. An English variety; prized highly as a late, showy market sort.

Stump the World.-A showy, white fleshed peach with a bright red cheek. Very large, juicy, sweet and good. Tree is average grade as to vigor and productiveness. Is ireestone and ripens near the end of September. 
Smock.-A first class late market peach. Ripens in early October and is considered first quality for canning or evaporating. Not sweet for eating, but has a distinctive, agreeable flavor. Large, yellow, orange red cheek; freestone. Origin, New Jersey.

Steadley.-Fruit very large, of a greenish white color; flesh white to the stone and of a delicious flavor. Early in October.

Triwmph. - A valuable commercial variety, to follow the Alexander. The fruit has a heavy coat of down, and in some seasons is subject to rot. Tree is hardy and very productive, but requires thorough spraying to control leaf curl and twig blight. The peach is yellow with red cheek, flesh not entirely free, with sweet, rich flavor. Early August.

Wonderful.-A variety noted for the great size and beauty of its fruit. Has a rich golden color nearly covered with bright crimson which shows up well in the basket. The flesh is yellow, firm, rich and highly flavored. First grade for market. First class for eating or cooking. This variety has a very small freestone pit and ripens near the middle of October. Origin, United States.
Waterloo.-Originated at Waterloo, N. Y. Of medium to large size; color whitish green, marbled with red, deepening into dark purple crimson in the sun; flesh greenish white, with an abundance of sweet, vinous juice; adheres some to the stone like Amsden, Hale's Early, etc. Ripened at Waterloo, July 14, 1878. In 1879 three or four days ahead of Alexander. For so early a peach it is a remarkable keeper, ripe specimens having been kept in perfect condition for nearly a week. This makes it valuable for shipping.

Yellow Rareripe.-Large, deep yellow, dotted with red; melting, juicy, with a rich flavor. Ripens one week later than Crawford's Early. Closely resembles Jacques' Rareripe.

Yellow St. John.-The earliest really good peach for either home use or market. Ripens before Early Crawford, and its fair size, yellow flesh, attractive color and good quality make it a satisfactory peach for all purposes, and a market peach of the first rank. The best of its season. A perfect freestone. Tree is vigorous and productive. Last of August. Origin, North America.

Wager.-Large, yellow, more or less color in the sun; juicy and of a fair flavor. While high quality and great beauty cannot be claimed for this fruit, the trees have such remarkable vigor and vitality that they not only produce fruit in great quantities, but produce it with a degree of certainty and regularity which is quite unusual. These facts commend it to all planters for market purposes. Last of August.

Wheatland.-Originated with D. S. Rogers, near Rochester, N. Y. Mr. R., who has large orchards, including the leading sorts, thinks this is the finest of all. Fruit large ; color golden yellow, with crimson tint; flesh firm and of fine quality. Ripens between Crawford's Early and Late.

These Elberta peaches were raised in the big orchard shown on page 27

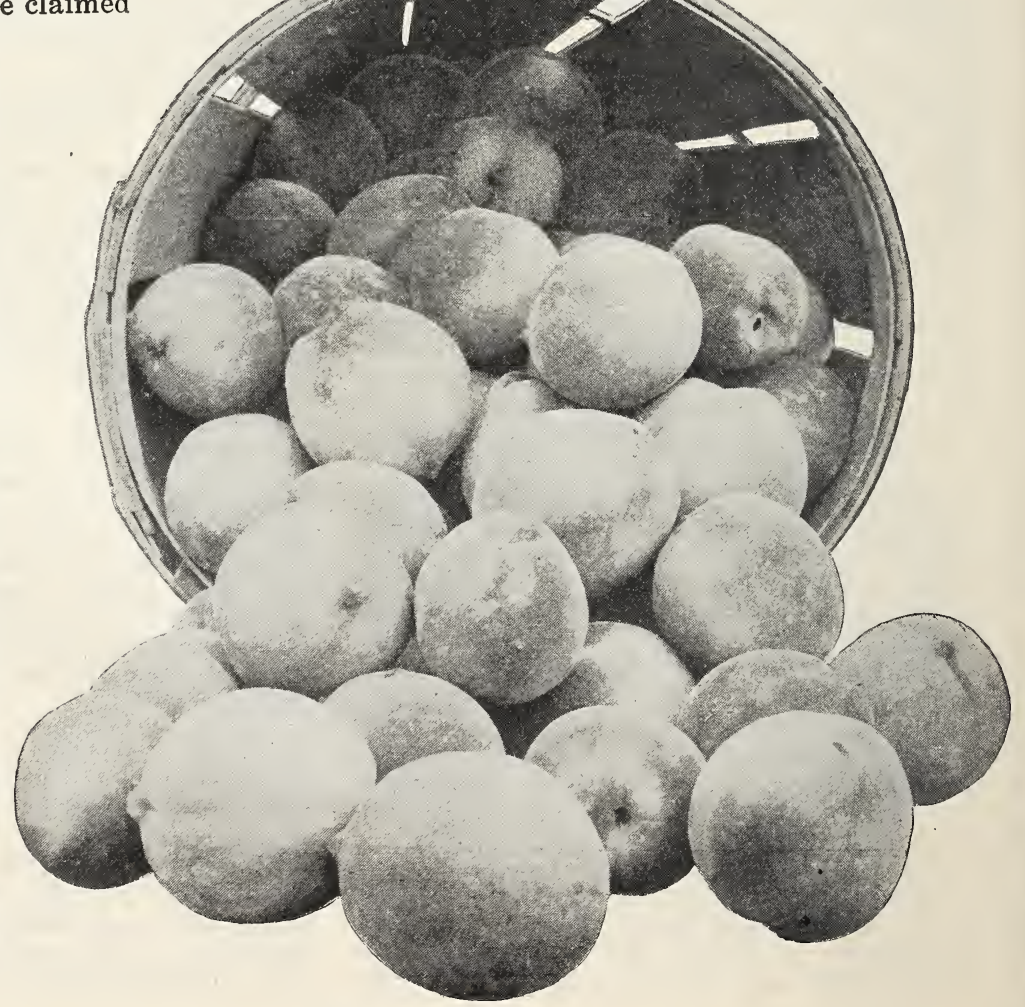




\section{QUINCE}

Q UINCE trees should be planted in rich, deep, moist, but well-drained clay soil. The tree responds quickly to good care and culture. Its greatest enemy is blight, which is combated with the same methods used with Pears. It is a dwarfish grower, and if not controlled will soon develop into shrub or bush, hence "suckers" and water spouts must be kept off and the tops open to sun and air. Quince can be planted 8 to 10 feet apart. Under proper conditions it bears heavily and regularly and is a highly profitable crop, since in all markets the demand for good Quinces is never fully supplied.

Orange or Apple.-More largely planted than any other variety. One of the old varieties that always bear and give good satisfaction wherever planted. Orange is large, bright golden yellow. Cooks very tender and has a great flavor. There is always a demand for this Quince.

Bourgeat.-This tree produces large crops of exceedingly large and handsome fruit, of a rich golden color. It ripens soon after Orange, but will keep until mid-winter. It is very hardy and free from leaf blight.

Champion.-Will bear more quickly than any other variety. Trees in the nursery row often bear when two years old. The fruit is large and handsome. Flesh cooks as tender as an apple and without hard spots or cores. Very fine for preserves, jellies, marmalades, etc. The tree is vigorous, hardy and very productive. Champion is a fine all around Quince. Ripens in November.

Rea's Mammoth.-A seedling of the Orange Quince; one-third larger, of the samie form and color; fair, handsome, equally as good and said to be as productive. Tree a hardy and healthy grower.

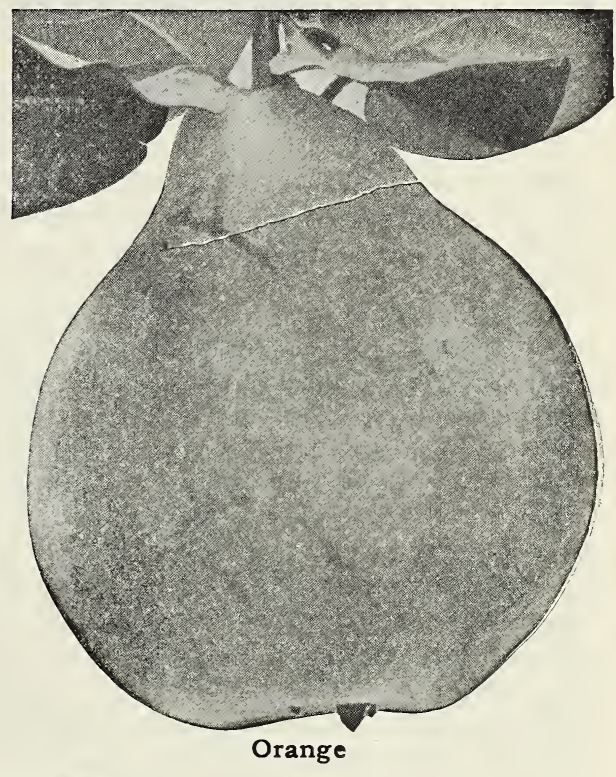

\section{APRICOT}

THE Apricot ripens a month or more before the best early Peaches come in, which explains the reason for the great demand and prevailing high prices. It should be planted in deep rich soil; and care should be taken to know that the sub-soil as well as the top-soil is dry.

Alexander.-A large, oblong, orange yellow fruit, spotted with red. Flesh is sweet, juicy and very good. It is a hardy, prolific bearer and very popular in the east. One of the best of the Russian varieties. Ripens early.

Early Golden.-An American variety of Apricot. Fruit is small, pale orange, juicy ana sweet. The tree is hardy and prolific. Ripens first of July.

Harris.-This variety is remarkable for its size, beauty and productiveness. It is extremely hardy; will stand the severest winter.

Montgamet.-A pale yellow Apricot, slight. ly tinged with red; flesh is firm, juicy and agreeably acid.
Moorpark.-The largest of all Apricots; orange in color with a red cheek. More money is made from these than from any other variety. Flesh is firm, juicy and very fine. Moorpark ripens in August.

Russian.-A native of Russia.

\section{NECTARINES.}

Boston.-Very large and handsome, deep yellow, with a bright blush, and mottles of red; flesh yellow to the stone, sweet, with a pleas. ant and peculiar flavor. Freestone.

Early Violet.-Medium size; yellowish green, nearly covered with dark purplish red; juicy, rich and highly flavored. Last of August. 
BROWN BROTHERS COMPANY, ROCHESTER, N. Y.

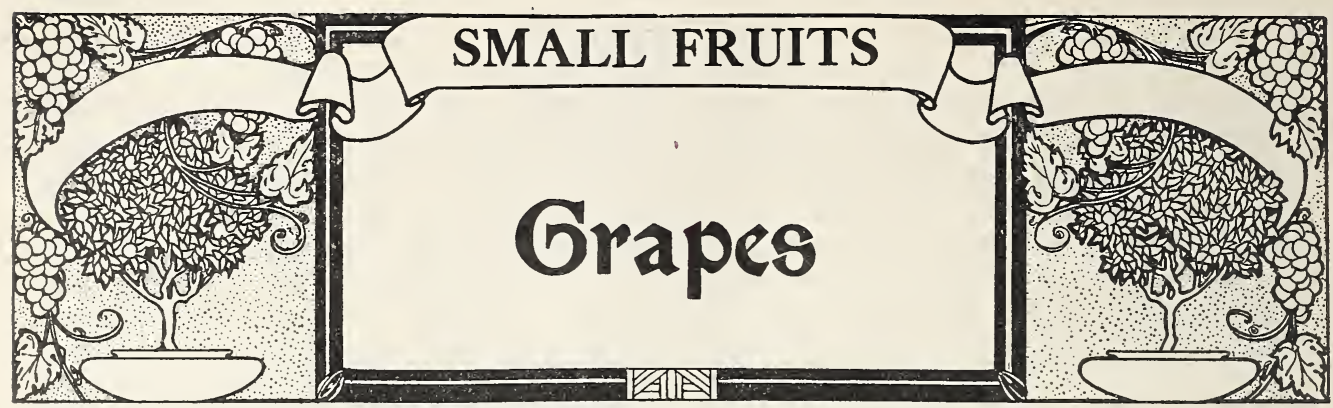

TVHEREVER you go, north, east, south and west, whether on hill or in valley, on poor soil or rich, you will find the grape generously giving of its bounty and loyal to its master whether he give care or neglect. If you plant but one fruit, plant the grape. Nothing is better for the money, nothing quite so sure to grow, nothing quite so sure to bear, nothing quite so sure to please every mouth. Plant it wherever you can find a spot six inches square. It has its likes, but it never insists on them. With its roots in any odd nook, you can lead it away in any direction to provide a grateful shade for a restful seat.

Srops-Crop moderately if you would have fine, well ripened fruit. A vine is capable of bringing only a certain amount of fruit to perfection, proportioned to its size and strength; but it usually sets more fruit than it can mature; reduce the crop early in the season to a moderate number of good clusters, and cut off all the small inferior bunches; the remainder will be worth much more than the whole would have been. A very heavy crop is usually a disastrous one.

Pruning-Annual and careful pruning is essential to the production of good Grapes. If the roots are called upon to support too much wood, they cannot bring to maturity a fine crop of fruit. The pruning should be done in November, December, February or March, while the vines are entirely dormant.

Training Vines-There are many methods of training grape vines, but as trellises are more generally employed, we will confine our suggestion to a description of the trellis method. To construct a trellis take posts of oak, cedar or chestnut 8 to 10 feet long, set them 3 feet in the ground and about 12 feet apart. Stretch No. 9 galvanized wire tightly along the posts and fasten hem to each. Let the first wire be 18 inches from the ground, and the distance between the wire 12 inches. Wooden slats about one by two inches may be substituted for wires. Trellises should be at least 10 feet apart, a greater distance preferable. Set the vines about 20 feet apart. Prune the vines to two canes each for two years after they are planted. In February or March these canes should be cut back to 5 or 6 feet each, and tied along the lower wire or slat of the trellis horizontally.

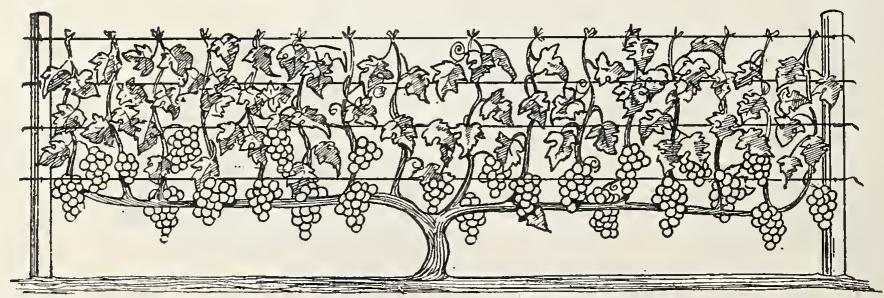

When the growth commences in spring the young shoots must be reduced by disbudding so that they may stand about a foot apart on the cane, selecting, 
of course, strong, healthy shoots; as they grow they are tied up to the second, third and fourth wire or slat, and all other superfluous ones removed, as well as the young laterals, which will appear on vigorous vines; but the first fruitbearing shoots are allowed to extend themselves at will until September, when they may be pinched off at the end to assist the ripening of the wood. The next pruning, which may be done in November or December, if it is desirable to lay the vines down and cover them over for the winter; or in February or March if not laid down, consists in cutting back all the young wood of the previous year's growth (except such shoots as may be required to extend the horizontal arms), to within one or two good buds of the bearing canes on the lower wire, giving the vine theappearance of the following cut:
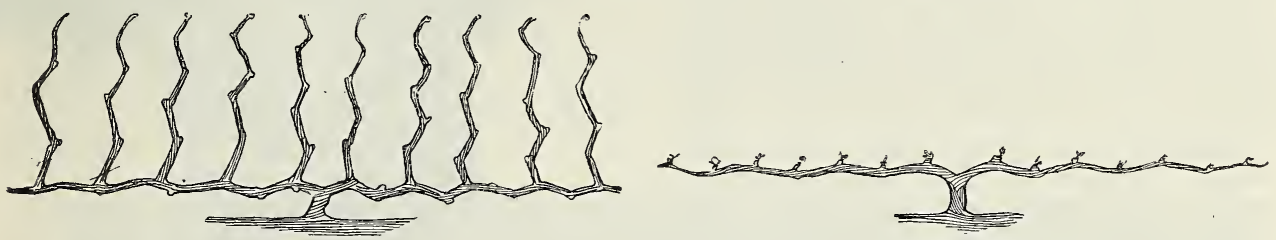

Each season thereafter the vines are to be treated in the same manner, cutting back every year to the lower wire or slat, extending the vine only in a horizontal direction, thinning vines in the rows by digging up every other plant if necessary, but never growing any grape above the second wire, and renewing the bearing canes by new shoots from the stumps when required.

Gathering and Keeping-Grapes for keeping, to be used in their fresh state, should be allowed to remain upon the vines until perfectly matured, but not much longer. Pick them when perfectly dry. Let them stand in open baskets or boxes for about ten days in a cool, dry room, and after sorting out all decayed and imperfect berries, pack them in shallow boxes and cover closely. Use no paper, but basswood or elm boxes if convenient. Pine and other resinous woods should not be used as they flavor the fruit disagreeably. After packing, keep the boxes where it is both cool and dry. Under careful management some varieties may be kept until spring.

The letters following descriptions indicate color of fruits, B (black); R (red or purplish); W (white).

Agawam.-(Rogers' No. 15)-One of the best of the red varieties; bunch variable in size; flesh tender and juicy. A good grower and bearer. $R$.

Amber Queen.-A new and promising variety, which originated in Massachusetts. Bunch and berry of medium size; color light amber; flesh tender to the center; juicy, sprightly and delicious. Larger than and as early as Delaware. W.

Brighton.-Flesh rich, sweet, and of the best quality, equal if not superior to Delaware; ripens early. Productive and vigorous. $R$.

Catawba.-Bunches large and loose; berries large, of coppery red color, becoming purplish when well ripened; vinous, rich; requires the most favored soils and situations, good culture and warm seasons to mature perfectly in Western New York. R.

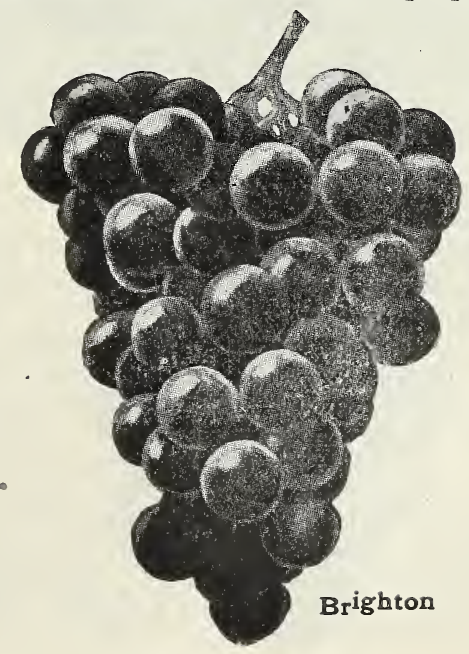


Campbell's Early.-Clusters large and handsome; berries large, nearly round, black, with light purple bloom; flesh rather firm, but tender; quality ' rich, sweet, slightly vinous; a strong and vigorous grower, with healthy foliage; very early; the berries do not drop easily from the clusters, and the fruit keeps a long time in perfection. B.

Concord.-Large and handsome, very hardy, productive and reliable; succeeds well over a great extent of country, and is one of the most popular market grapes. B.

Clinton.-Bunches small and very compact; berries small and sprightly; when thoroughly ripe is a good table grape and keeps well. B.

Champion.-A large grape of medium quality; a strong grower and very hardy; the earliest of all; succeeds in all sections and this makes it one of the most valuable market grapes. B.

Delaware--One of the finest of our native grapes. Ripens early. Bunches small and compact; berries small, light red, with a violet bloom, beautiful; sweet, sugary and vinous, with a musky aroma. It justly claims a place in every garden. $R$.

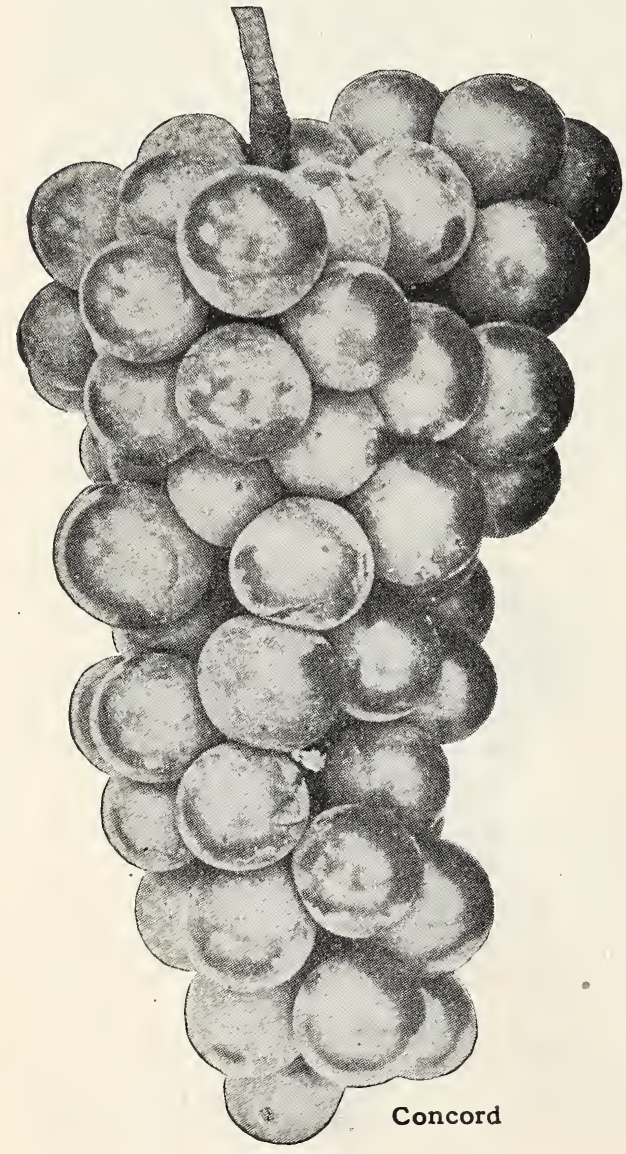

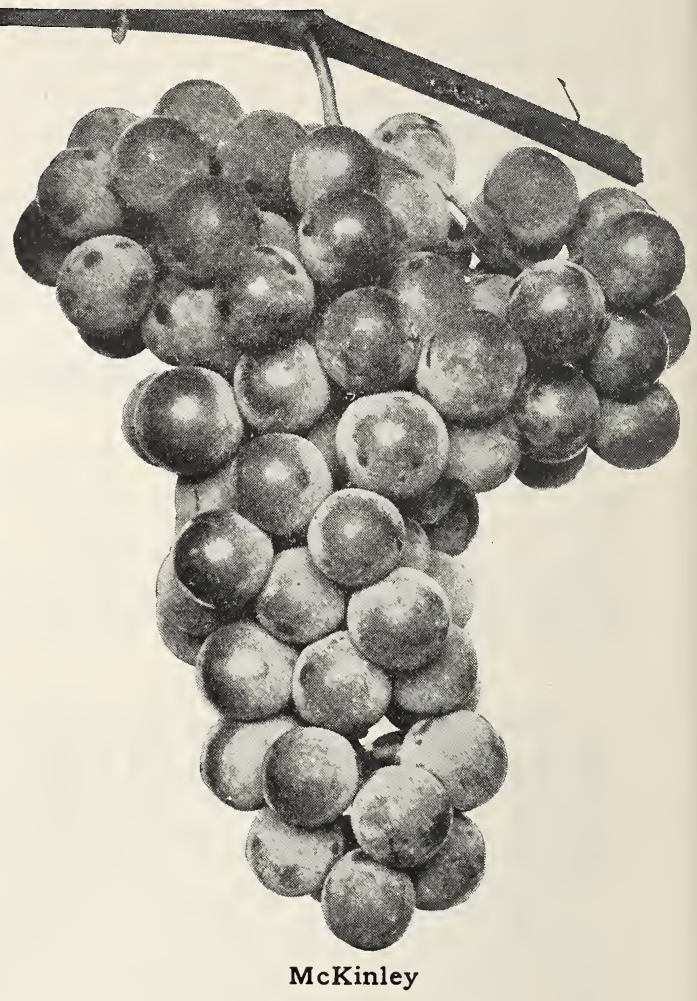

Empire State.-A purely native variety; remarkable strong grower; foliage resists mildew; extremely hardy, very productive, fruit ripens early, of best quality; hangs firmly to the stem, continues a long time on vine; remarkably good keeper. W.

Green Mountain.-A very early and delicious grape; pulp tender and sweet, with but one or two seeds: bears young and profusely, and ripens from the 25th of August to the 1st of September. The only grape thus far tested that ranks first, both in earliness and quality. W.

Hartford Prolific.-Bunches rather large; berries large, globular; color almost black, covered with a beautiful bloom; of a fair quality; ripens three weeks before the Isabella; valuable for its abundant bearing and early maturity. B.

Isabella.-Bunches long, large, loose; berries large, oval; juicy, sweet and musky. A vigorous grower, hardy; an immense bearer; a good keeper. B.

Lindley.-(Rogers' No. 9.)-Bunch medium, somewhat loose; berry medium to large, round; a rich shade of red; very handsome and attractive; flesh tender, sweet, with a rich aromatic flavor; ripens soon after the Delaware; vigorous and productive. We regard it as one of the best red grapes. $R$. 
Moyer.-A new grape originated in Canada. In habit of growth and hardiness it resembles the Delaware very much, but ripens earlier. Flavor sweet, delicious; skin tough but thin; pulp tender and juicy. $R$.

Moore's Diamond.-Bunch large, compact; berry medium size; color greenish white with a yellow tinge; flesh juicy and almost without pulp; very good. Vine vigorous and productive. $\mathrm{W}^{\top}$.

Moore's Early.-Bunch large, berry round; color black, with a heavy blue bloom; quality better than the Concord. Vine exceedingly hardy; has been exposed to a temperature of more than 20 degrees below zero without injury, and is entirely exempt from mildew or disease. Its earliness makes it desirable for an early crop, maturing as it does ten days before the Hartford, and twenty days before the Concord. B.
McKinley.-A large early white grape, as large as the Niagara and productive; strong grower, and robust foliage. It is a cross between Niagara and Moore's Early. It was orig. inated near where the Niagara Grape originated. It is fully ten days earlier side by side. Bunches very large and compact, very sweet with no acid around the seeds and no puckery taste in the skin. It is the coming Early Grape for market. W.

Niagara.-Bunch medium to large, compact, occasionally shouldered; berry large, roundish, uniform; skin thin but tough, pale green, changing to pale yellow, with a thin whitish bloom; flesh slightly pulpy, tender, sweet. Remarkably vigorous, healthy and productive; foli. age thick and leathery. Ripens with the Concord. All things considered probably the most valuable white grape in cultivation. W.

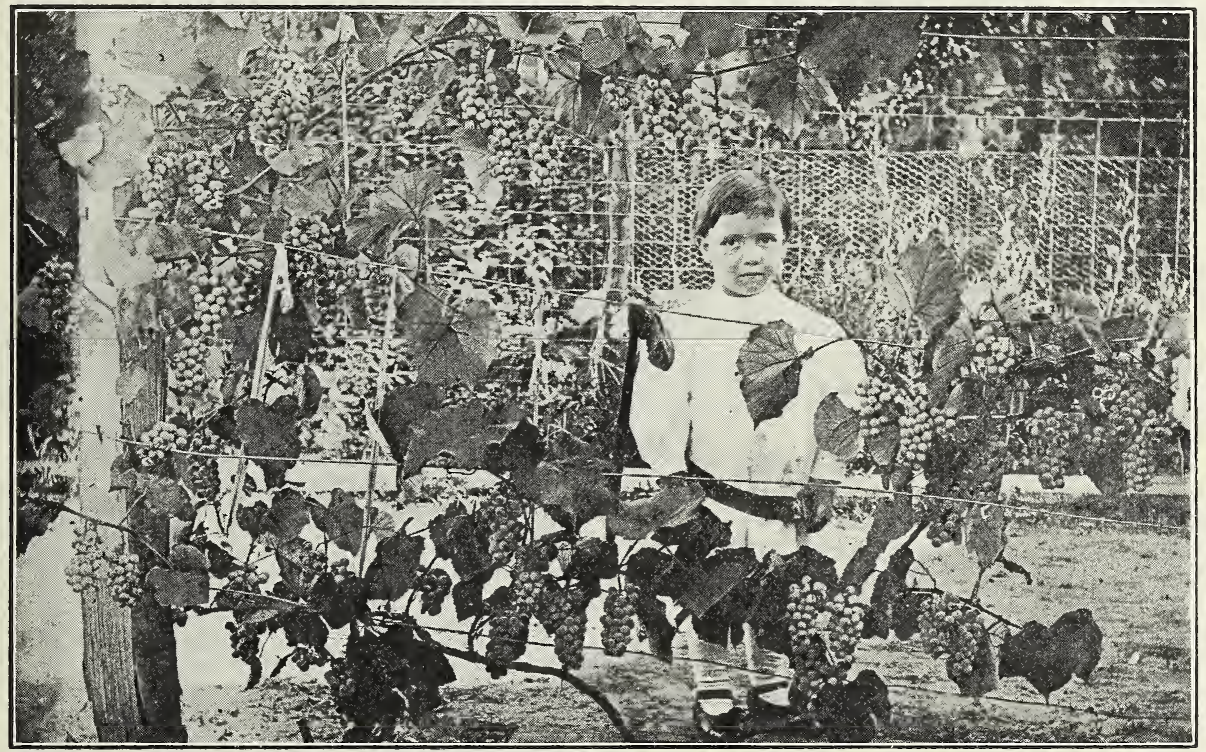

Niagara

Pocklington.-Is a seedling from Concord; fruit a light golden yellow, clear, juicy and sweet to the center, with little or no pulp; bunches very large, sometimes shouldered; berries round, very large and thickly set. First of September. W.

Salem.-(Rogers' No. 22)-This is regarded as the best of Mr. Rogers' hybrids. Bunch large, berry large, round; flesh tender, juicy, with a rich, aromatic flavor; slight pulp; a good keeper. $\mathrm{R}$.

Vergennes.-Originated at Vergennes, Vt., near Lake Champlain. The originator says of it: "Clusters large; berries large; color light amber; flavor rich and delicious, ripening here fully as early as Hartford Prolific." Its keeping qualities are superior. $R$.

Wilder.-(Rogers' No. 4)-Large and black; bunches generally shouldered; berry round and large; flesh buttery, with a somewhat fibrous center; sweet, rather sprightly; ten days earlier than the Isabella. B.

Worden.-A seedling of the Concord. Bunch large, compact, handsome; berries large-larger than those of the Concord. It ripens a few days earlier, and is superior to it in flavor. Very popular for the vineyard and garden. B. 


\section{CURRANTS}

THE Currant ripens just before Raspberries are gone, continuing in prime order for several weeks. It is of pleasant acid flavor, hardy, a free grower, easy to cultivate, and a certain and heavy cropper. Because of its hardiness and free growing tendencies, it is often neglected, but good cultivation and careful pruning will double the size and quality of the fruit and increase the profits. Currants are the most profitable of smaller fruits. An acre yields from 200 to 250 bushels of fruit. Plants should be set in rows four feet each way, allowing plenty of light and air. For protection against the currant worm dust a little white hellebore powder over the bushes when the leaves are damp. Do this as soon as worms appear.

Black Champion.-Bushes large and favor of fruit particularly delicious. It hangs long on the bunches, and un. like other varieties, bears the severest pruning without detriment.

Black Naples.-Very large; black, rich, tender, and excellent for jellies and wines; very productive.

Cherry.-Very large, deep red, rather acid; bunches short. Plants erect, stout, vigorous and productive.

Fay's Prolific.-Originated in Chautauqua County, N. Y. A cross between Cherry and Victoria; of large size, fine flavor, and claimed to be five times as prolific as the Cherry. A great acquisition.

La Versaillaise.-Very large, red; bunch long, of great beauty and ex. cellent quality; one of the finest and best and should be in every collection. Verv productive.

Lee's Prolific Black.-A new Eng. lish variety. The fruit is large and of superior quality; the bush is a vigorous grower and enormously productive, rendering it very profitable.

Perfection.-A cross between Fay's Prolific and White Grape. Color is a beautiful bright red. Size as large as the Fays or larger, the clusters averaging longer. It is the most productive large red currant of which we have any knowledge. Season of ripening is about the same as that of Cherry or Fay. Quality, rich, mild, sub-acid, plenty of pulp with few seeds. Less acid and of better quality than any other large red currant in cultivation. A good grower, with very large healthy foliage. Awarded the Barry, Fifty Dollar Gold Medal of the Western New York Horticultural Society, July, 1901, after three years' trial. The first fruit to receive this grand prize. Received Highest Award given any new fruit at the Pan-American Exposition, also received prize at Louisiana Purchase Exposition, St. Louis, 1904.

Victoria.-A late bearing red variety. Berries are large and grow in very long bunches. Victoria is a fine bearer and is grown for com-

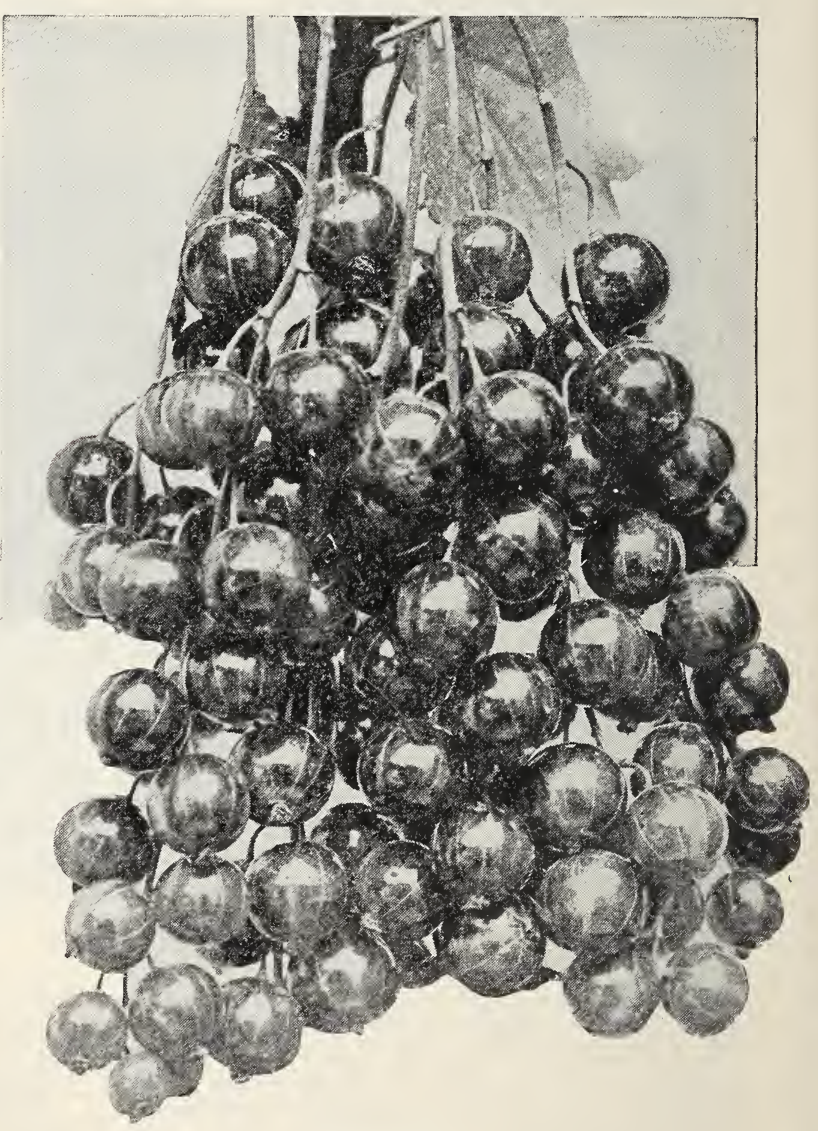

Perfection

mercial purposes in many parts of the country.

White Grape.-Very large, yellowish white, sweet, of very mild acid. Excellent quality : very productive. Best of the white varietios.

Wilder.-It is one of the strongest growers and very productive. Bunches of berries very large, bright, attractive red color, and hang on bushes longer than any other variety. 


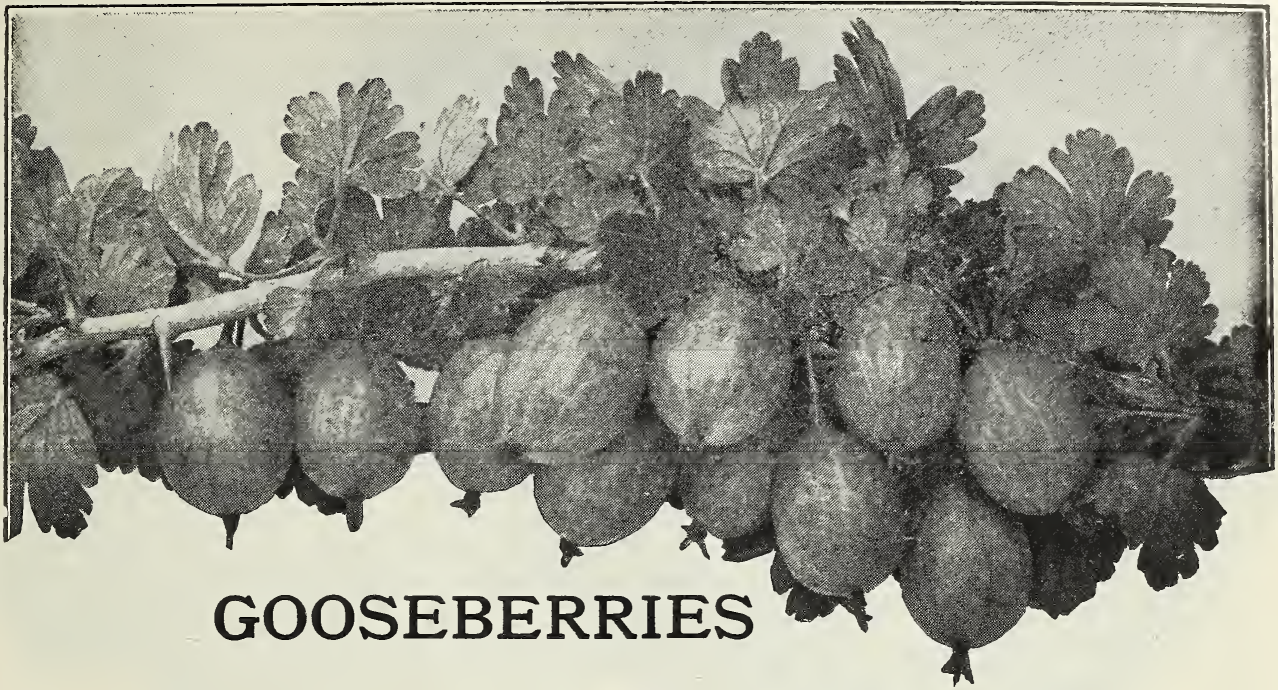

$\mathrm{T}$ HIS fruit is so useful for cooking, when green or ripe, and it may be canned with such facility that it is beginning to be cultivated very extensively for both home use and market.

It requires the same cultivation and treatment for worms as the currant. The worms attack the Gooseberry before the currant bushes, and if a few of the former are set near a currant plantation, and the worms exterminated on these, there will be little if any trouble from them on the currant bushes.

The American varieties, though not quite so large as the English sorts, are of fine quality and are not subject to mildew.

Chautauqua.-Strong and vigorous. Berries light yellow, free from spines and hair, trans. parent. Very sweet. Fruit 1 to $1 \frac{1}{2}$ inches in diameter.

Columbus.-Large, handsome, greenish yellow; excellent variety. Very productive. A fine garden variety.

Downing.-Medium size. Whitish green; juicy. Soft and good. Very prolific. A great market berry.

Golden Prolific.-A remarkably strong, vigorous and upright grower, with dark green glaucous foliage, which resists mildew perfect. ly, and persistently hangs on until the end of the season. The fruit is of the largest size oblong, good samples measuring $13 / 4$ inches in length. Color golden yellow; flavor decidedly good; very productive.

Houghton.-Roundish, medium in size; sweet, very productive.
Industry.-Very large, an English variety. Large, oval, dark red, rich and nice flavor.

Josselyn.-This new American Gooseberry is as large as the largest English variety. Berry smooth; very prolific and hardy; quality and foliage the best.

Keepsake.-Very large, straw colored, excellent flavor. A good market variety. A sure cropper.

Pearl.-This berry has been tested in nearly all of the Experimental Stations in the U. S. and it has proven a wonderful producer. Free from mildew.

Smith's Improved.-From Vermont. Large oval, light green with bloom; flesh moderately firm, sweet and good. Vigorous grower.

Victoria.-A red variety with enormous productions. A fine flavor, ripens ahead of Industry. 


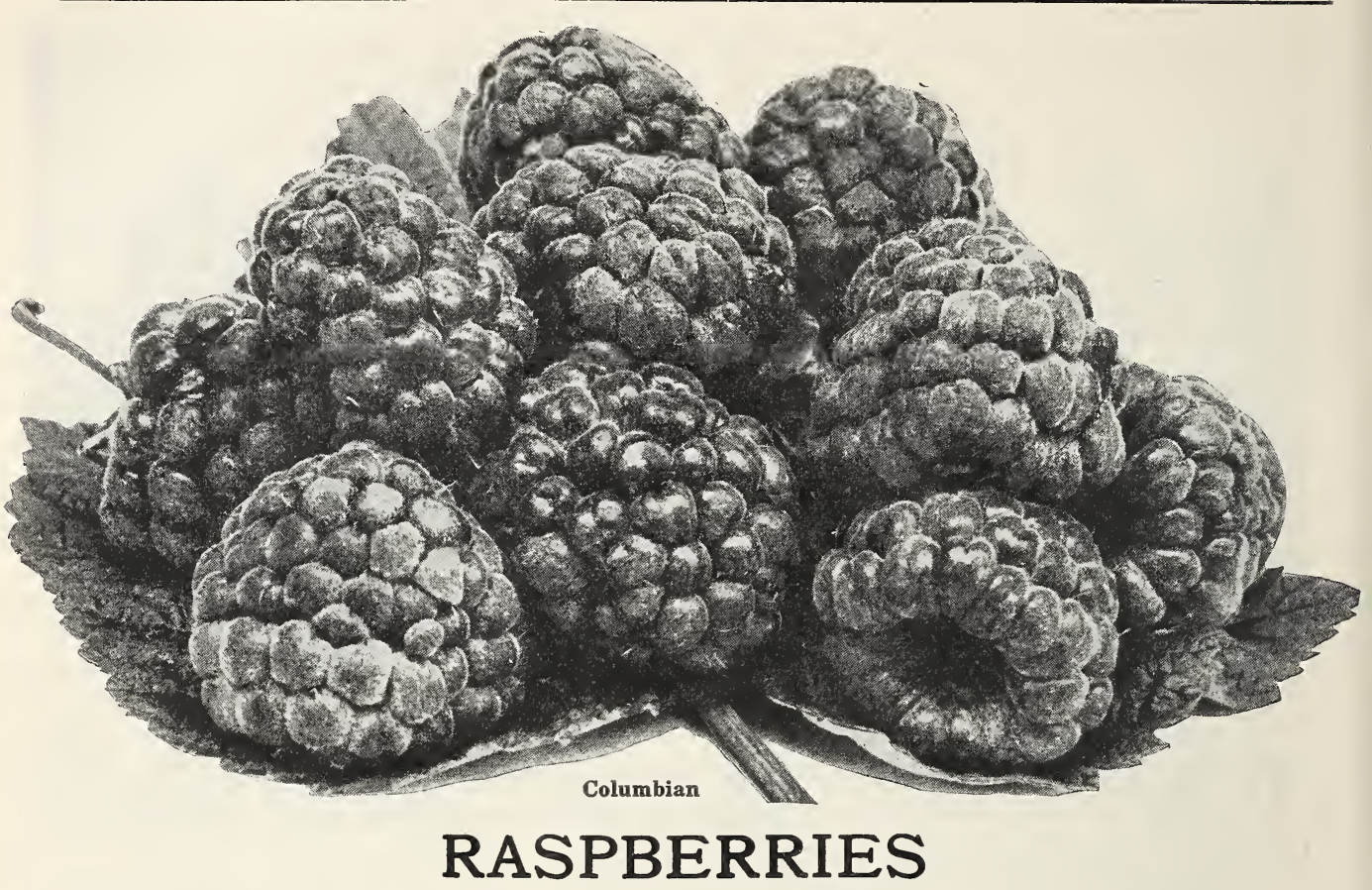

Plant in good soil and manure it from time to time freely. The hills should be not less than four feet apart each way. Cut out the old and weak shoots each year, preserving not over six for fruiting. If the location is much exposed and the plants inclined to killdown seriously, they may be bent over in the fall on mounds of earth formedat one side of the hills and covered sufficiently to keep them down until spring. Surplus suckers take strength from the bearing plants. They should be cutaway or hoed up frequently.

Raspberries may be made very profitable with good cultivation.

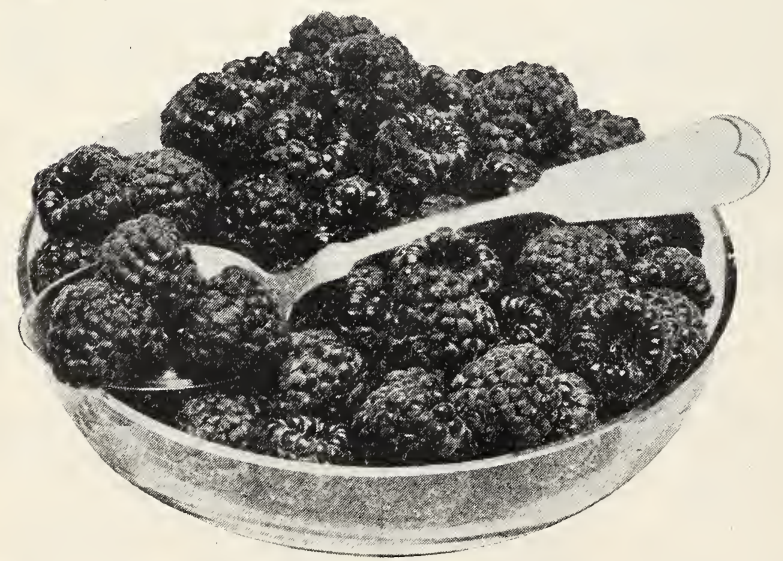

Gregg

\section{Black Raspberries}

Cumberland. - The largest of them all. Good quality, hardy and productive. Fruit firm, similar to Gregg. Keeps and ships well. One of the most profitable varieties. Ripens midseason.

Eureka.-Large, juicy, rich, hardy and a big producer. A valuable early blackcap.

Gregg.-A very large berry of excellent quality. Produces larger crops and is fine for evaporating or canning. Makes juicy, rich pies.

Gault.-(The Greatest Novelty in small Fruits)-Fruit immense size; commences to ripen with Gregg, continuing two or three weeks longer, when fruit on young canes commences to ripen, continuing until frost. Young canes frequently produce clusters of 80 to 100 perfect berries. 
Kansas.-One of the best blackcaps. Hardy, handsome, juicy and firm. An excellent field or garden variety.

Mammoth Cluster.-The largest black cap except Gregg. Canes of strong growth and very prolific. Berries large and of fine quality.

Ohio.-A very strong growing hardy sort; fruit nearly as large as Mammoth Cluster, more productive than any other variety, and one of the most if not the most valuable for market.

\section{Red and Yellow Raspberries}

Brandywine.-(Susqueco) - L a r g e; bright red; very firm. Valuable for market on account of its fine shipping qualities.

Columbian.-The greatest Raspberry of the age. It is a seedling of the Cuthbert, grown near the Gregg, and is believed to be a cross between the two. It is enormously productive, of large size and excellent quality. Season of fruiting from July 12th to August 15th. It

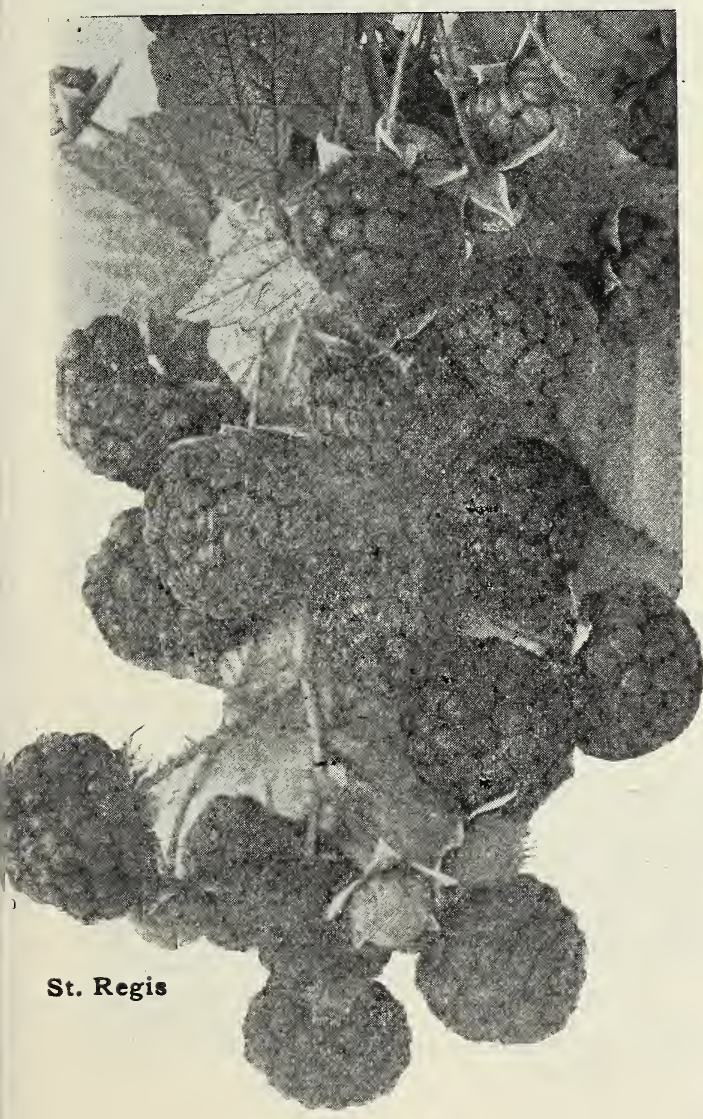

lias stood 2o deyrees below zero without injury, is propagated from the tips and does not sucker. The color is dark red; adheres to the stem, does not crumble in picking and is a splendid shipper. It has yielded over 8,000 quarts per anre.

Cuthbert.-Medium, conical, hardy variety, of deep, rich crimson. Very luscious and highly Havored. One of the best market varieties.

Golden Queen.-This variety is a seedling of the Cuthbert, but the color of the fruit is a rich golden yellow. The flavor is of the highest quality; in size equal to Cuthbert. Immensely productive; a very strong grower and hardy enough for entire northern latitudes, having stood uninjured even when the Cuth. bert suffered.

Haymaker.-(New)-The most vigoroug grower of all raspberries. Very hardy. Fruit very large, conical; color bright red and very attractive; flavor superb; delicious for table use and splendid for canning. It is a prodigious bearer, of long season; fruit of fine texture; does not drop from the bush. A superb shipper.

Herbert.-Very hardy, canes strong and vig. orous; bright red, the largest of all red Raspberries; sweet, juicy. Fine for table use. Enormously productive.

Louden.-Ripens with the earliest and hangs to the last. In productiveness it is beyond any red raspberry known, and is a famous shipping berry. It is as hardy as the Turner and is of superior quality.

Miller's Red.-Vigorous and sturdy in cane; very early. Fruit large and profuse; beautiful and brilliant in color; sweet, luscious flavor. Nothing in the way of red raspberries since the advent of the Cuthbert can be compared with the Miller in point of value.

Marlboro.-One of the best early reds. Hardy and a good producer. Ripens together.

St. Regis.-This everbearing red Raspberry be:lrs the first season. One of the greatest raspberries ever introduced. Plants of the St. Regis put out in the Fall or early April gave ripe berries on the 20th of June. For four weeks thereafter the yield was heavy, and the canes continued to produce ripe fruit without intermission until late October. The berries were large and beautiful and full flavored to the very last. The St. Regis is the only raspberry, as far as known, that is practically sure to produce a crop of fruit the season planted. $A$ warded the highest certificate of merit by the American Institute of New York. 


\section{BLACKBERRIES}

NEARLY all of the Blackberries will bear on good fruit land, particularly good on sandy soil. They require the same culture as Raspberries. Keep soil free from weeds and grass. Plant in rows of seven feet apart if in field and five feet apart for garden. When the canes reach the height of three feet in summer pinch off top; this will cause them to throw out laterals. Setting plants $7 \times 3$ feet apart you can get 2,078 plants to an acre. $5 \times 3$ feet apart will allow 2,904 plants to acre.

Agawam.-Ripens earlier than other kinds, and has a flavor similar and equal to the wild berry. Perfectly hardy.

Ancient Briton.-One of the best old varieties. Vigorous, healthy and hardy. Producing large crops with fine quality, bringing highest market price. Will bear in far North, Central or South.

Blower.-The largest of the blackberry family. Plant is upright and hardy. One of the most productive, a single plant producing over two thousand berries. Jet black. A good shipper. Ripens about July 15 and continues for six weeks.

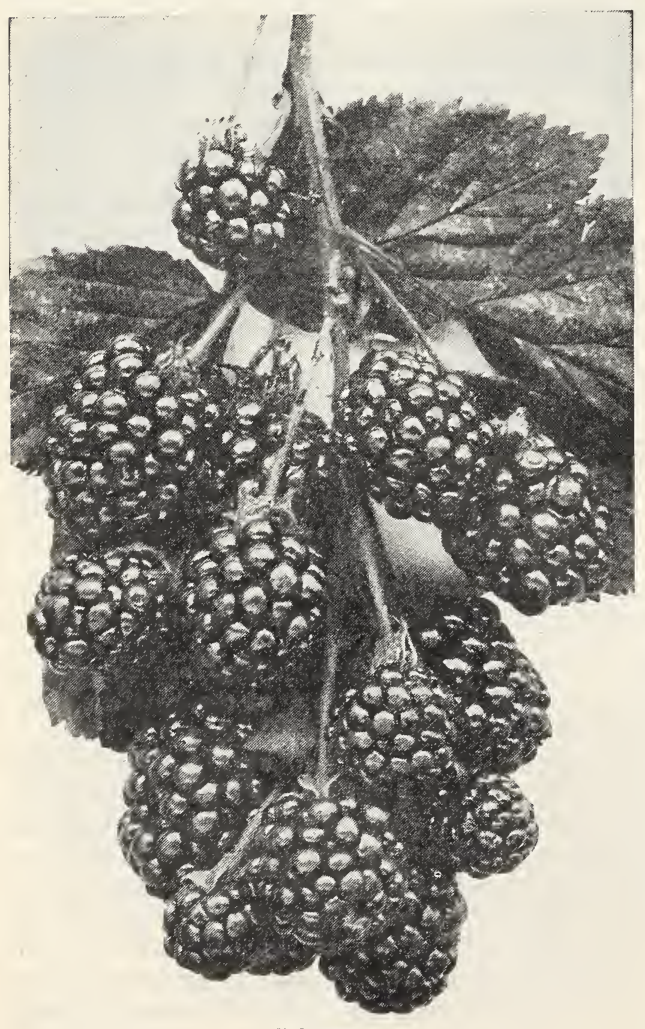

Blower

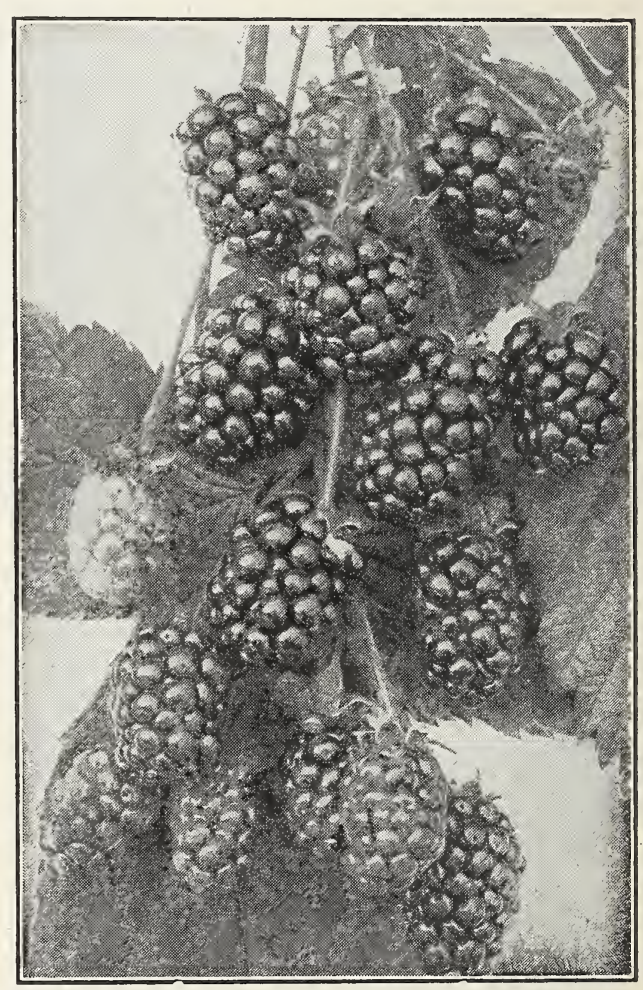

\section{Rathbun}

Eldorado.-Vigorous and hardy. Stands the severe winters of the Northwest without injury. Jet black. Bears in clusters and ripens together. Sweet and juicy. Free from hard core.

Erie.-Very large and very hardy. A strong grower and great bearer, producing larger, sweeter berries; earlier in ripening than any other sort.

Kittatinny.-Large, black, sweet; soft when black; very hardy; ripens up gradually, like the Lawton. One of the best except in Northern sections. 
Rathbun.-Origin Western New York. A strong erect grower with strong stem, branch. ing freely; will root from tip of branches like a raspberry. Hardy, having endured 20 degrees below zero, and produced a good crop. Forms a neat, compact bush 4 to 5 feet high, producing its immense fruit abundantly. Fruit is sweet and luscious, without hard core, of extra high flavor, jet black, small seeds; firm enough to ship and handle well. Very large size, resembling the Wilson and fully equal to that grand variety, with the addition of hardiness.

Snyder.-Extremely hardy. Very productive. Bears every year. Free from hard core. Grows upright. Fruit easy to pick.
Taylor.-Will stand thirty below zero. Berries large and productive and of fine quality. Fruit sweet, juicy and coreless. A valuablo variety.

\section{DEWBERRY}

Lucretia.-A low-growing, trailing blackberry. Hardy, and very productive with fine foliage and white flowers. The fruit ripens early; is many times one and one-half inches long by one inch in diameter. Soft, sweet and luscious. Free from hard core. Ripens before late raspberries are gone. Should be mulched to keep berries off from soil.

\section{ASPARAGUS}

Barr's Mammoth.-(Barr's Philadelphia Mam. moth)-Originated with Crawford Barr, a prominent market gardener of Pennsylvania. It is one of the earliest varieties, very productive and grows to the largest size.

Columbian Mammoth White-Produces shoots that are white and remain so as long as fit for use, very robust and vigorous in habit.

Conover's Colossal.-Immense size, remarkably tender and high flavored, vigorous grower, sending up from fifteen to twenty sprouts each year, from one to two inches in diameter, color deep green and crown very close. Can be cut one year sooner than the other varieties.

Palmetto.-Until recently we believed that

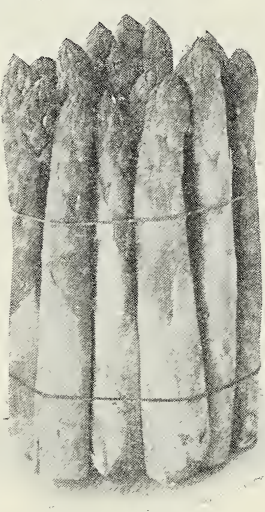

the Conover's Colossal was the best sort known, but we are now forced to concede that the Palmet. to is earlier and a better yielder, and more even and better in growth, and it will eventually super. sede the old favorite. The average bunches contain fifteen shoots, meas. uring $13 \frac{1}{2}$ inches in circumference and weighing nearly two pounds. It has been tested both North and South and has proved entirely successful in every instance.

\section{RHUBARB}

The plants should be set four feet apart each way, and the stalks will be fit for use the second season after planting.

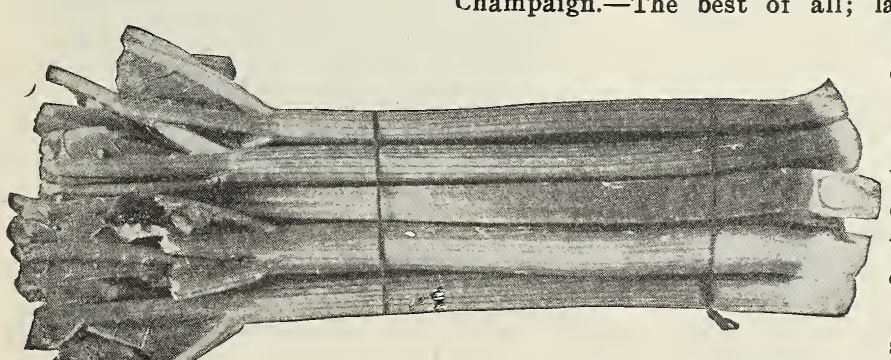

rge and of the finest flavor.

Early Scarlet.-Rather small, early and good.

Myatt's Linnaeus. - Those who have never grown this variety, which is of superinr quality, will hardly recognize the old "Pie Plant." It is an early, tender variety, without being in the least tough or stringy, with a mild, sub-acid flavor. Largest and best of all for market purposes. Victoria.-Early, tender, medium size. 


\section{STRAWBERRIES}

\section{SPRING DELIVERY ONLY}

WE CANNOT FILL ORDERS FOR STRAWBERRIES FOR CUSTOMERS SOUTH OF VIR. GINIA OR WEST OF KANSAS

Strawberry Plants are sent direct to the customer by Parcel Post or Express, depending on size of order. We guarantee delivery in good shape, as plants are dug and shipped the same day. No plants carried over night. Every plant shipped fresh and in perfect order.

\section{DESCRIPTION OF BEST SORTS}

Americus (P) Thrifty grower, fruit good quality, medium to large in size, rich red in color, delicious flavor.

Brandywine (P) A strong grower. Will thrive on any soil. Berries rich dark red with bright yel. low seeds on surface. Spice flavor. A delightful table berry.

Dunlap (P) A prolific grower on any soil and under all conditions. Berries large size, bright glossy red. A strictly high class berry.

Great Scott (P) A veritable giant among straw. berries. GREAT in size, beauty, yield and quality. Taken premiums everywhere on account of large size and rich flavor.

Glen Mary (P) A popular sort among market gardeners. Berries rich, dark, clear all through, high flavor, ripening mid-early to mid-season. A great market variety.

MONROE (P) Awarded Barry Gold Medal. Dark red, large, very smooth, extra firm and fine grained. High quality, uniform in shape. Brings fancy prices, much above ordinary berries. Mr. Joseph A. Morgan, the originator, says: "BEST of 50 tested $\nabla a$ rieties. Yield double that of any of the others and my best seller." Another grower says: "I find it hard to sell other varieties of strawberries to my customers after they have had some of the MON. ROE.'

\section{NUT TREES}

\section{CHESTNUT-Castanea.}

Amercan.-A well known forest and nutbearing tree; of great value for ornamental purposes.

Spanish.-A valuable species for both ornament and fruit. It forms a handsome lawn tree and produces fruit three or four times as large as the American variety. Not hardy north of Philadelphia, Pa.

Numbo.-A New Jersey seedling of the Spanish Chestnut, and claimed to be as hardy as the American.

Filbert, American.-Smaller, and with a thicker shell than the English, but of good flavor; hardy and productive.

Japan Walnut.-Perfectly hardy here, rapid grower, handsome form, large leaves, bears young and abundantly. A fine ornamental tree.

Butternut.-A rapid growing native tree, producing edible nuts.
Oregon (P) Originated in Oregon and our stock came direct from the parent plants. It is a vigorous grower, adapted to all soils and locations. Berry very juicy. Strictly hardy, free from blight and recommended to all growers.

Progressive (P) Big producer, good size, good color, good quality. A popular variety.

Ryckman (P) A very early big berry, leader of 15 varieties. Attracted wide attention at St. Louis exhibition. A perfect shipper and valuable market sort.

Sample (Imp.) Very productive and grows freely on any soil. Is a wonder for productiveness. Berries large to very large, globular, bright red, moderately firm and good. It has yielded 500 bushels per acre.

Superb (P) Best and most profitable Fall bearing variety. Yields heavy crops. Large berries, of good quality and appearance wherever grown.

Warfield (Imp.) Very productive, medium size, dark glossy red. A fine canning berry. Will ship long distances. A well known variety that needs no recommendation.

Wilson (P) A well known variety that has for years been the standard of excellence. Very large, dark red, firm, rather acid. A good market sort and superb for canning.

\section{DIRECTIONS FOR PLANTING}

We advise planting strawberries in rows five feet apart and the plants one foot apart. This would require 8,700 plants to the acre, or a trifle over 50 plants to the rod of land. In small gardens it is often advisable to plant them one foot apart each way. With good care, one can reasonably estimate one pint of fruit to the plant. A number of the varieties we have listed produced from ten to fifteen thousand quarts per acre last year. There is a per. manent demand now-a-days for all the strawberries that a man can raise. The canning factories will take all they can get at a fair price which will net the farmer from $\$ 250$ to $\$ 800$ an acre, depending on the care given to the plants and crop.

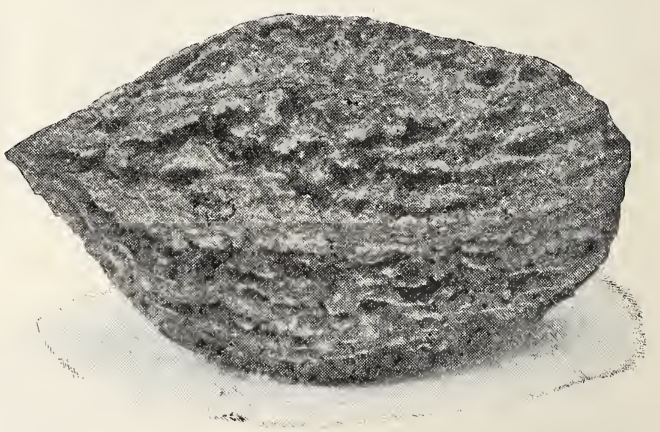

Butternut

Black.-The well known native species; hardy, prolific and valuable; timber in point of durability is difficult to excel.

English.-(Madeira Nut)-This rich and fine flavored nut is moderately hardy, and makes a vigorous growth. 


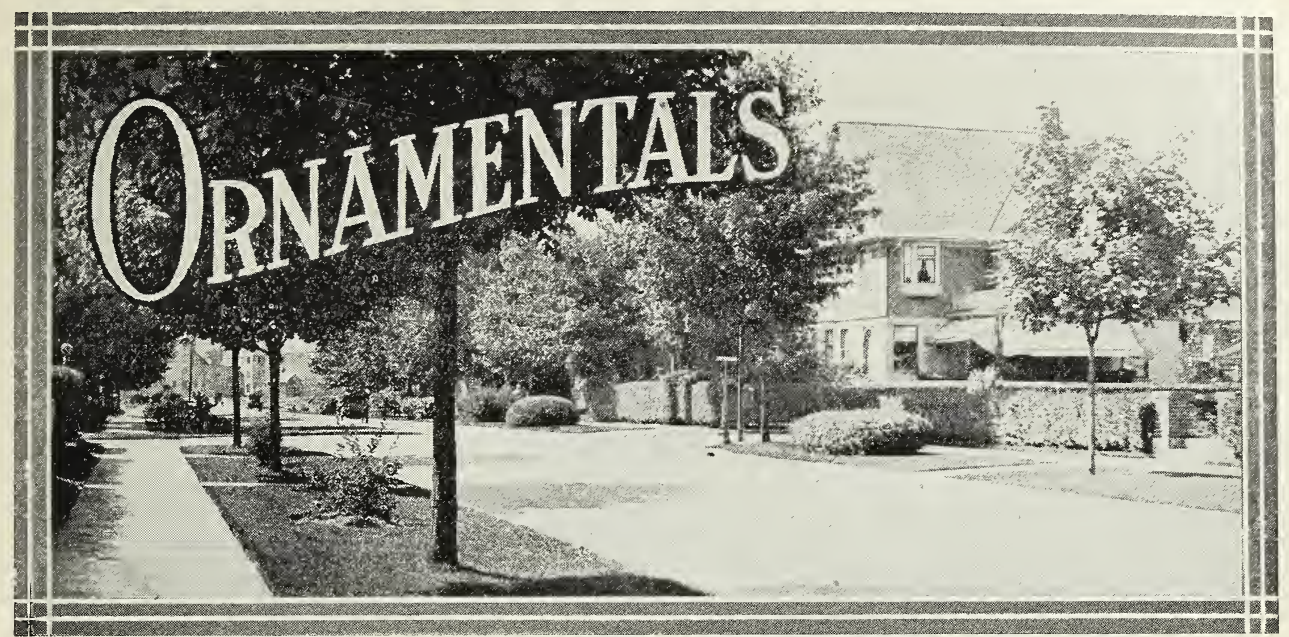

THE growing custom of bringing the home and its surroundings into more 1 complete harmony by a well planned arrangement of trees, shrubs and flowers is one that cannot be too highly commended. Flowering shrubs for borders of walks and roadways, screens of bushes to shut off objectionable views; gardens of old-fashioned flowers, intermingled with trailing vines, enhance not only the beauty and cheerfulness of the home, but we should consider that the actual value of the property has increased largely.

For City Street and Avenue.-Sugar Maple, Norway Maple, American Elm, American Ash, Pin Oak, Red Oak, White Oak, American Lin. den, Oriental Plane.

Quick-growing Street Trees.-Silver Maple, Ash-leaved Maple, Bolleana Poplar, Carolina Poplar, Lombardy Poplar.

Best Lawn Trees.-Norway Maple, Schwed. ler's Maple, European White Birch, Cut-leaved Weeping Birch, Catalpa Speciosa, Purple-leaved Beech, Tulip Tree, Maiden Hair, Cucumber Tree, European Larch, European Mt. Ash, the Oaks, English Elm, the Lindens.

Low-growing Lawn Trees.-Japanese Maple, Aralia, Catalpa Bungei, Japan Weeping and
Flowering Cherries, the Dogwoods, the Doubleflowering Thorns. Fern-leaved Beech, Japanese and Chinese Magnolias, Weeping Mulberry, Bechtel's Flowering Crab, Japanese Tree Lilac.

Trees for Damp Places.-Pin Oak, Swamp White Oak, Red Maple, Silver Maple, the Willows, the Alders, American Elm, Yellow Birch, American White Birch.

Trees for Dry Places.-Scarlet Oak, Red Oak, Aralia, White Birch, Sugar Maple, Beeches.

Trees for Seashore Planting.-Norway Maple, Oriental Planes, Carolina Poplar, Lombardy Poplar, Bolleana Poplar, Pin Oak, Red Oak, White Willow, Honey Locust, Tamarix.

\section{FLOWERING TREES}

Named in the order in which they flower:

MAY.-Almond Davidiana, Cherry, Doubleflowered: Judas Tree, Chinese Magnolia, in variety; Almonds, Cornus Florida, Horse Chest. nuts. white and red; Crabs, flowering; Peach, double-flowered; Bird Cherry.

JUNE.-Mountain Ash, Thorns, in variety; Laburnum, White Fringe, Locust, white; Vir. gilia Lutea, Catalpa, Lindens, in variety.
JULY.-Chestnut, American, Catalpas.

Trees which produce ornamental fruit succeeding the flowers: Celtis occidentalis, dull red fruit as large as peas.

Cornus florida.-Oval fruit in a head.

Cratægus.-(Thorns) - Scarlet and yellow fruit in September and October.

Pyrus (Crab), Mountain Ash.-Scarlet fruit in September and October. 
Trees for Spring Planting Only.-While most kinds of trees can be safely transplanted in the Fall, there are a few that are rarely suc. cessful unless carefully moved in the Spring; the Birches, the Beeches, Japanese Maples, the Larches, Magnolias, Tulip Trees, Flowering Cherries and Peaches, Judas Tree, the Oaks, Sweet Gum and all Nut-bearing trees.

There is no surplus of really high-grade Nursery Stock in the market today; we therefore warn our customers against trees and plants offered at ridiculously low rates. Poor stock is dear at any price.

Deciduous Trees, Shrubs and Vines can be planted in Spring or Fall. In the far north, where the weather is too severe, plant in the Spring. Evergreens should be set out in Spring.

\section{Care in Planting}

Preparation of the Roots.-Cut off smoothly all bruised or broken roots up to the sound wood. This prevents their decaying and hastens the emission of new roots and fibres.

Preparation of the Top.-This consists in cutting back the top and side branches in such a way as to correspond with the more or less mutilated roots, as follows: Trees with branching heads should have the small branches cut clean out, and the larger ones, intended for the framework of the tree, cut back to within two or three buds of their base.

In cases where there is an abundant root and small top or few branches, the pruning need be very light, but where the roots are small and the top heavy, severe pruning will be necessary. These remarks are applicable to all deciduous Trees and Shrubs. Evergreens seldom require pruning, but Arbor Vitæ and other Evergreens planted in hedge rows may be advantageously shorn immediately after planting.

Pruning.-Pruning has the effect to render trees and shrubs unnatural and inelegant. We refer to the custom of shearing trees, particularly conifers, into cones, pyramids and other unnatural shapes. Every tree, shrub and plant has a habit of growth peculiar to itself, and this very peculiarity is one of its beauties. If we prune all trees into regular shapes we destroy their identity. The pruning knife should be used to assist nature, and operated with good judgment; to lop off straggling branches, to thin the head of a tree which has become too dense, and to remove dead wood.

Each shrub has peculiarities of habit and foliage, and we should aim to preserve them as far as possible. Judicious pruning to secure health and vigor is necessary, but trimming all kinds of shrubs into one form shows a lack of appreciation for natural beauty, to say the least. Weigelas, Deutzias, Forsythias and Mock Orange flower on the wood of the preceding year's growth, hence the shrubs shoula not be pruned in Winter or Spring, but in June, after they have finished flowering, when the old wood should be shortened or cut out, thus promoting the growth of the young wood, which is to flower the following season.

Spiræs, Lilacs, Althæs and Honeysuckles may be trimmed during the Winter or early in Spring, but the branches should only be reduced enough to keep them in good shape. The old growth should be occasionally thinned out and the suckers and root sprouts removed when they appear. The best time, however, for pruning all shrubs is when they have done flowering. The Hydrangea paniculata grandiflora should be severely cut back and thinned early in Spring.

Pruning Evergreens.- Use the knife occasionally to thicken the growth and preserve the shape. This can be done in April or May, just before the trees start to grow.

For Lawns and Small Places.-Whatever specimens are planted should be of the finest species, of moderate size, of graceful habits of growth and handsome foliage.

A pendulous tree or one with variegated foliage may be occasionally introduced, and will add to the beauty of the grounds. De-1 pend mainly upon dwarf shrubs for small places, and in selecting, aim at securing a succession of bloom. Dwarf evergreens are very useful, and in small grounds hardy herbaceous border plants can be used with the most satisfactory results; a proper selection will afford as much bloom as ordinary bedding plants, and at half the trouble and expense.

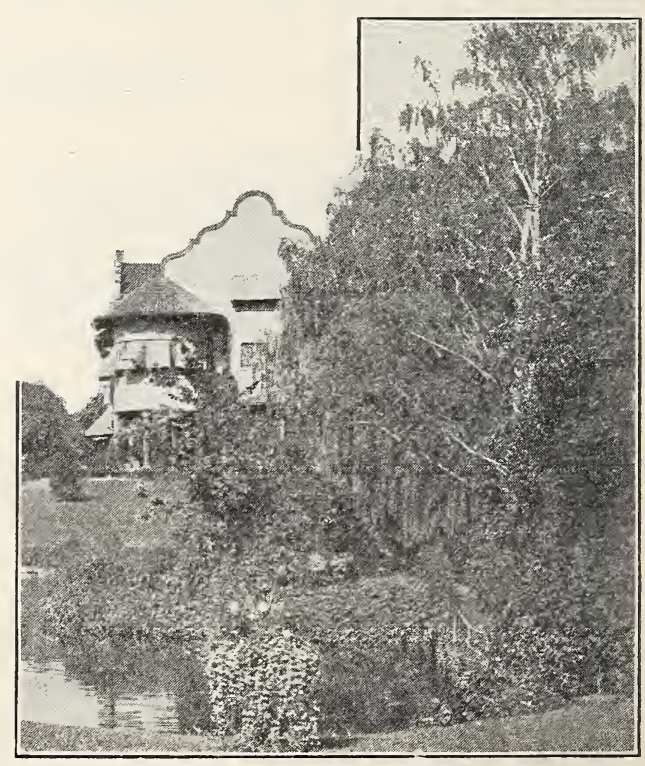

American White Birch 


\section{UPRIGHT DECIDUOUS TREES}

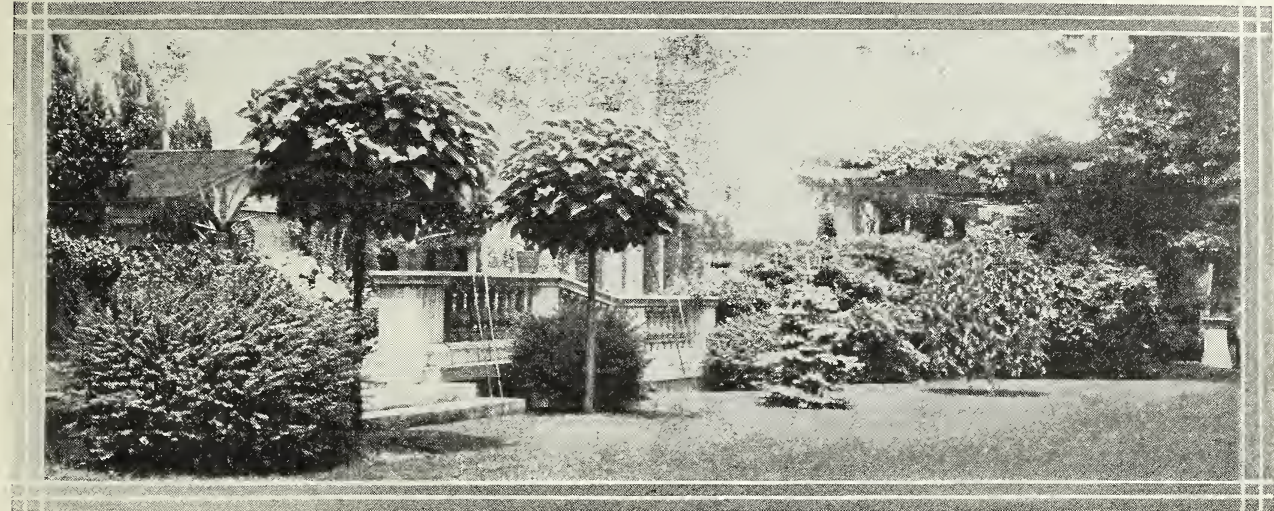

Thunbergii

\section{ALDER - Alnus,}

Imperial Cut-leaved Alder-(Lacianata Im. perialis)-A beautiful tree with deep cut foliage. Hardy, vigorous growth, forming a handsome shaped head.

\section{ASH-Fraximus.}

There are many varieties of $\mathrm{Ash}$ and all are clean, healthy and vigorous.

Ash, Gold-Barked.-(Aurea)-A conspicuous tree at all times, especially in winter on ac. count of the yellow bark and twisted branches.

American White Ash.-A well known native tree. Desirable for lawns or streets.

European Ash.-A lofty tree of rapid growth with spreading head and gray bark. Pinnate leaves and black buds. An odd but ancient looking tree.

Willow-leaved Ash.-Long, willowy leaves; fine habit and rapid grow in. A desirable lawn tree.

\section{BEECH-Fagus.}

The Beeches are noted for their rich, glossy foliage and large size at maturity. They are fine for lawn decorations.

European Beech.-(Sylvatica)-Like American variety, darker bark and more compact habit.

Fern-leaved Beech.-(Heteraphylia)-Round habit, beautiful cut fern-like foliage. During the growing season its young shoots are like tendrils giving a wavy aspect to the tree.

Purple-leaved.-(Purpurea)-Discovered in a German forest. An elegant, vigorous tree, growing 40 to 50 teet high. Foliage deep purple, changing to crimson. Like all varieties of the Beeck, this is difficult to transplant, hence rmali trees three feet high are preferable.

\section{Blue Spruce Mulberry}

\section{BIRCH-Betula.}

American White Birch.-An American species of rapid growth, with triangular, taper pointed, smooth and glossy leaves.

Cut-leaved Weeping Birch.-(See Weeping Trees).

European White--(Alba)-A fine tree of moderate size, with silvery bark and slender branches.

Young's Weeping.-(See Weeping Trees).

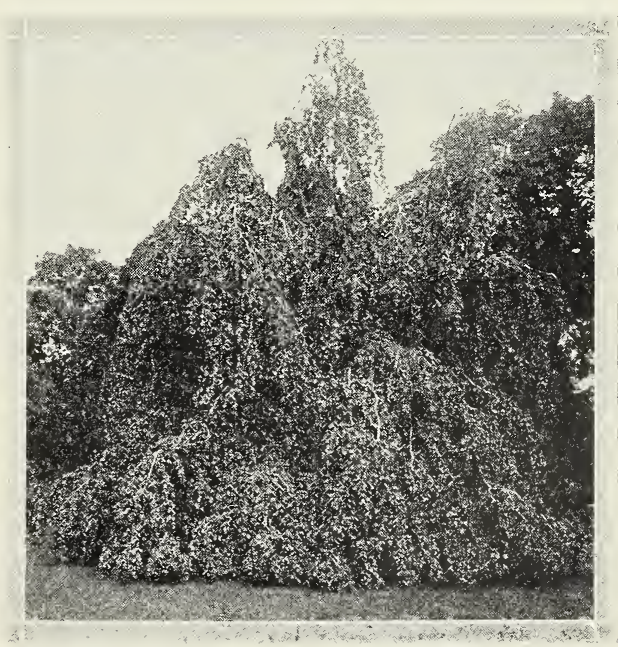

Weeping Beech 


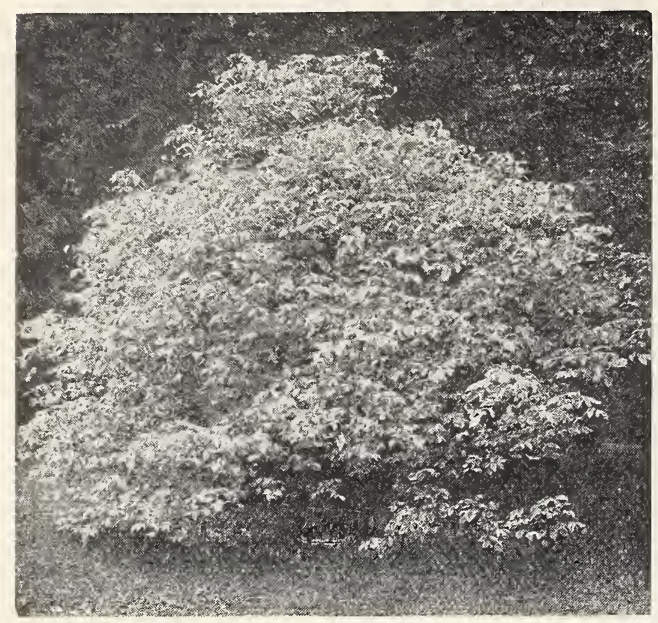

Flowering Dogwood

\section{CATALPA.}

The Catalpas flower in July. The blossoms are showy, large and fragrant. Leaves large, heart-shaped and yellowish green. They are effective, tropical-looking lawn trees, some varieties producing long seed pods, that remain on all winter.

Bungei.-(Umbrella Catalpa)-Grafted on stems six to eight feet high, it malies an umbrella-shaped top without pruning. Perfectly hardy, and flourishes in almost all soils and climates. Leaves large, glossy, heart-shaped, deep green; lay like shingles on a roof; always make a symmetrical head. One of the most unique trees; a valuable acquisition, desirable for lawn, park and cemetery planting.

Speciosa.-This early-blooming, upright variety is much hardier than the syringa-leaved, having proved itself able to stand the severe winters of Wisconsin and Iowa, making when planted in groves, straight symmetrical trees, suitable for posts or railway ties, for which purposes it is one of the most useful trees known, lasting in many instances nearly or quite a century.

\section{CRAB-Pyrus.}

Bechtel's Double Flowering.-One of the most beantiful of the many fine varieties of flowering Crabs. Tree of medium size, covered in early spring with large, beautiful, double, fragrant flowers of a delicate pink color. From a distance the flowers have the appearance of small Roses. Blooms when quite roung.

\section{CHERRY-Cerasus.}

Double Flowering.-(Flore alba plena)-A tree of medium growth, producing clusters of double white flowers in May. Blooms so profusely as to completely hide the branches from view.

\section{DOGWOOD (Cornus).}

Red Flowering-(Flore rubra)-A valuable variety producing beautiful carmine flowers; of great value.

White Flowering-(Florida) -A fine American tree, growing from sixteen to twenty-five feet high. Foliage of a grayish green color; very glossy and handsome, turning in the autumn to a deep red, rendering the tree one of the most beautiful objects at that season. The flowers appear before the leaves in the spring and are about three inches in diameter; white and very showy. It is one of the most valu. able ornamental trees.

\section{ELM-Ulmus.}

The Elms are so well known that it is unnecessary to refer to their beauty and value for ornamental planting. We grow the American. There is no finer tree for street and park planting.

American White Elm.-The noble spreading and drooping tree of our own forests.

Camperdown Weeping Elm.-(See Weeping Trees).

English Elm.-An erect, lofty tree, of rapid, compact growth, with smaller and more regularly cut leaves than those of the American, and darker colored bark. The branches project from the trunk almost at right angles, giving the tree a noble appearance.

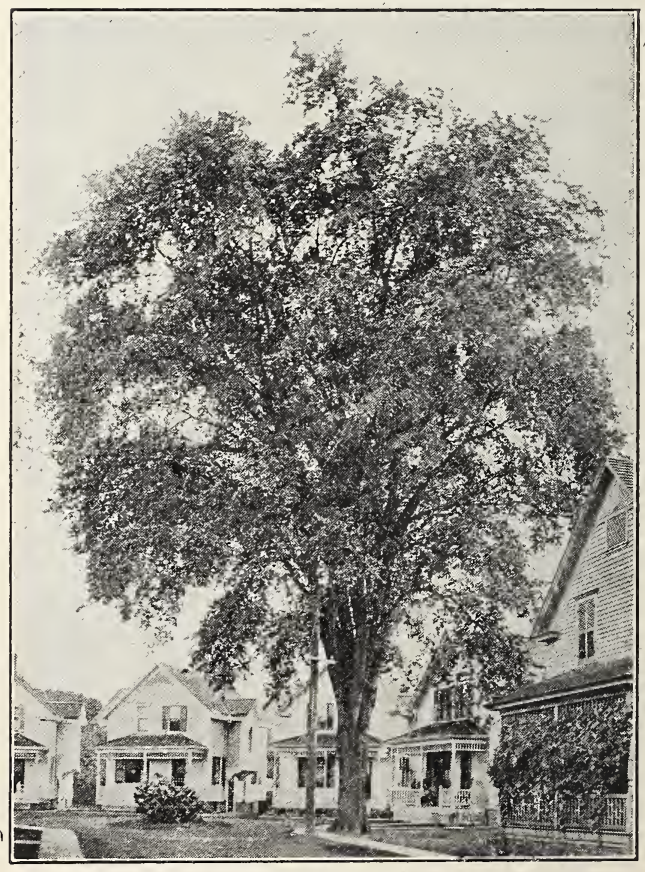

American Elm 


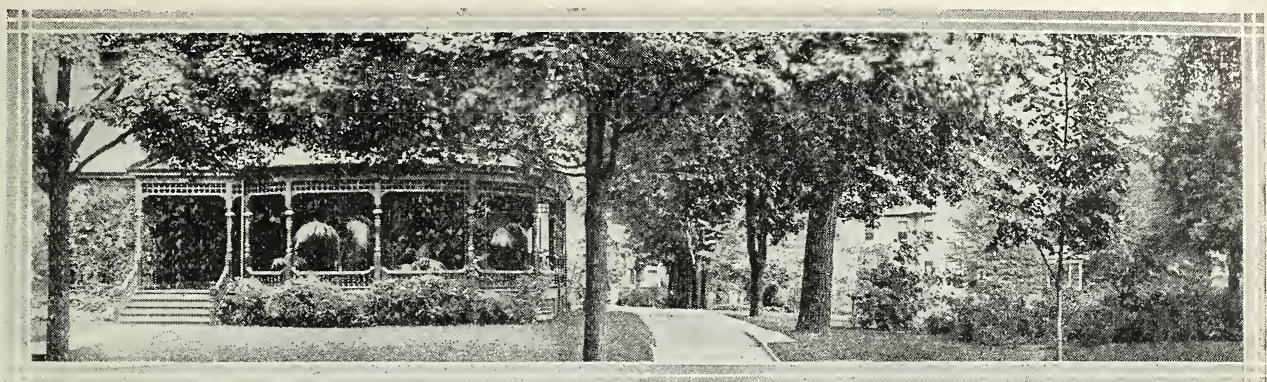

Showing the Effect of Well Placed Trees

Purple-leaved.-A striking variety; with erect branches and purple leaves.

Scotch (Montana).-A fine spreading tree, of rapid growth and large foliage. When fully grown, forty to fifty feet high.

\section{HORSE CHESTNUT-Aesculus.}

European or White Flowering Horse Chestnut.-A beautiful well-known tree of roundish form with dark green foliage and abundance of spikes of white flowers, slightly marked with red. Hardy.

Double Flowering Horse Chestnut.-A fine and rare variety. Larger panicles than common sort. Pyramidal in form. No fruit.

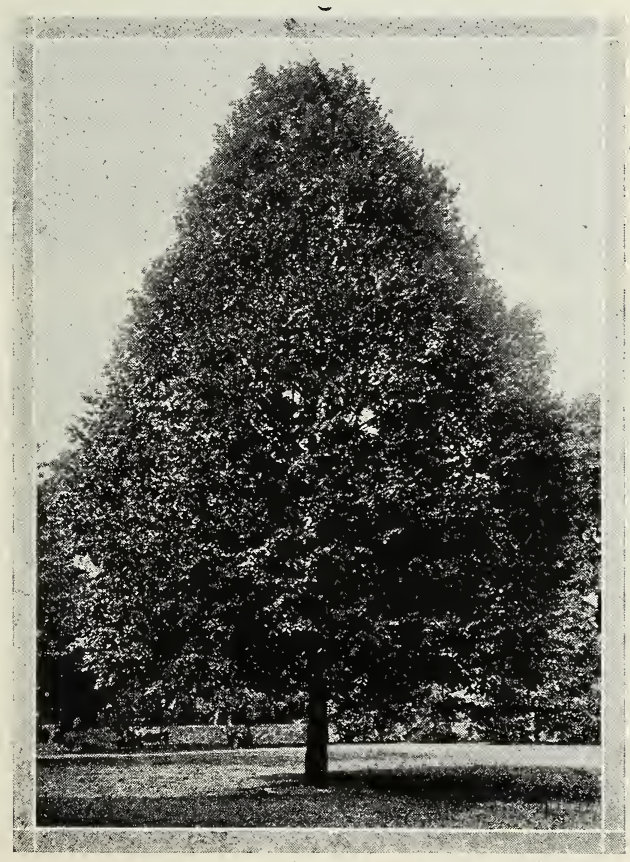

American Linden

\section{JUDAS TREE, OR RED BUD-Ceris.}

American Judas.-A very ornamental native tree, of medium size, irregular rounded form, with perfect heart-shaped leaves of a pure green color, glossy surface above and grayish green beneath. The tree derives the name of Red Bud from the profusion of delicate reddish purple flowers with which it is covered before the foliage appears. Flowering at the same time with the Chinese Magnolias, it may be planted among them in groups with fine effect. Grown as single specimens they are also beautiful and attractive, and deserve to be classed among our finest ornamental trees.

Japan Judas.-Of medium size, rounded form. foliage deep shining green and heart-shaped; flowers larger than those of American, and of a rich, reddish purple color.

\section{LARCH-Larix.}

European Larch.-A beautiful, rapid-growing tree, of irregular, pyramidal form, with small drooping branches; valuable for timber.

\section{LABURNUM-Cytisus.}

Common, or Golden Chain.-Bears long, pen. dent racemes of golden flowers in June; smooth and shiny foliage. Very showy and beautiful, and valuable for every lawn. When fully grown, fifteen to twenty feet high.

\section{LOCUST OR ACACIA-Robinia.}

Rose or Moss Locust.-A native species of spreading, irregular growth, with long elegant clusters of rose-colored flowers in June, and at intervals all the season.

\section{LINDEN OR LIME TREE-Tilia.}

The Lindens are all beautiful. In addition to many other valuable qualities which they possess, their flowers yield a delicate perfume.

American Linden or Basswood.-A rapid growing, large-sized, beautiful native tree, with very large leaves and fragrant flowers. 


\section{BROWN BROTHERS COMPANY, ROCHESTER, N. Y.}

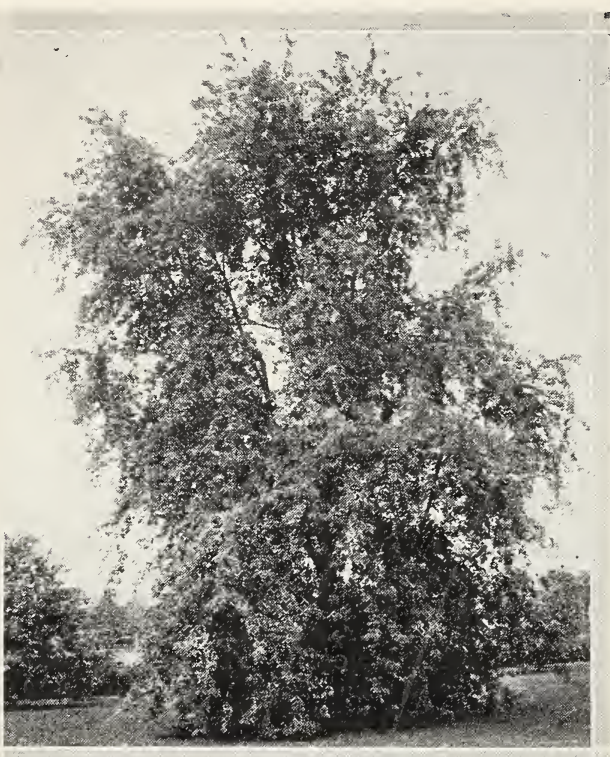

Wier's Cut Leaf Maple

European Linden.-A very fine pyramidal tree of large size, with large leaves and fragrant flowers.

White-leaved European Linden.-From Hungary. A vigorous growing tree, of medium size and pyramidal form, with cordate acuminate leaves, downy beneath and smooth above. It is particularly noticeable among trees by its white appearance. Its handsome form, growth and foliage render it worthy, in our opinion, to be classed among the finest of our ornamental trees.

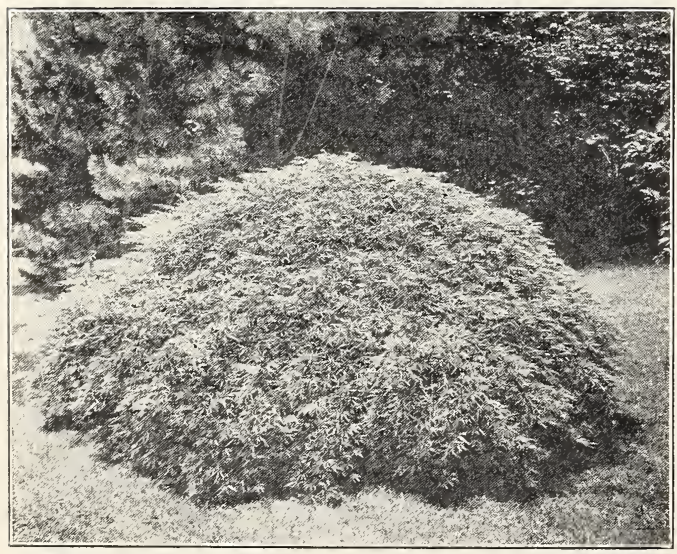

Cut Leaf Japanese Maple
MAPLE-Acer.

Very valuable for shade. Vigorous and free from disease. Hardy and adapted to all soils. Recommended for street planting.

Ash-leaved, or Box Elder (Negundo)-A native tree, maple-like in its seeds and ash-like in foliage; of irregular spreading habit.

Japan Blood-leaved.-Of dwarf habit and rounded form; foliage five-lobed and serrated; reddish crimson in June, changing to dark purple which it retains all summer.

Norway Maple.-A native of Europe. Now planted very largely, on account of its clean, broad foliage of rich deep green. Stout, vigor-

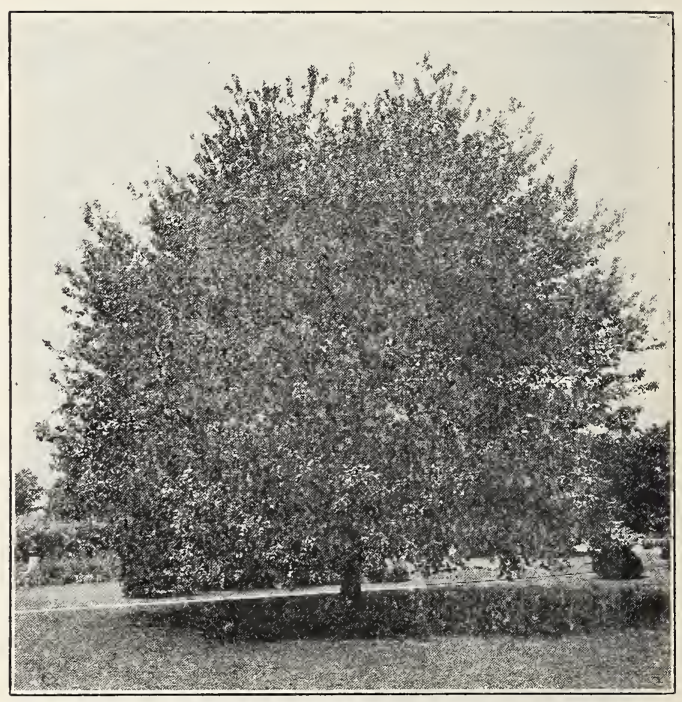

\section{Scarlet Maple}

ous grower, of spreading rounded form. Very hardy and makes dense shade. One of the most popular maples.

Purple Sycamore Maple.-Foliage dark green on the upper surface and red purple underneath.

Red or Scarlet Maple.-Conspicuous in Spring for its masses of red blossoms, and in Fall for its glowing crimson foliage.

Silver-leaved Maple.-Hardy, rapid grower. Foliage bright green above and silver beneath. Quick shade producer.

Schwedler's Norway Maple.-The early foliage of this variety is a bright crimson, fading to purplish green. 


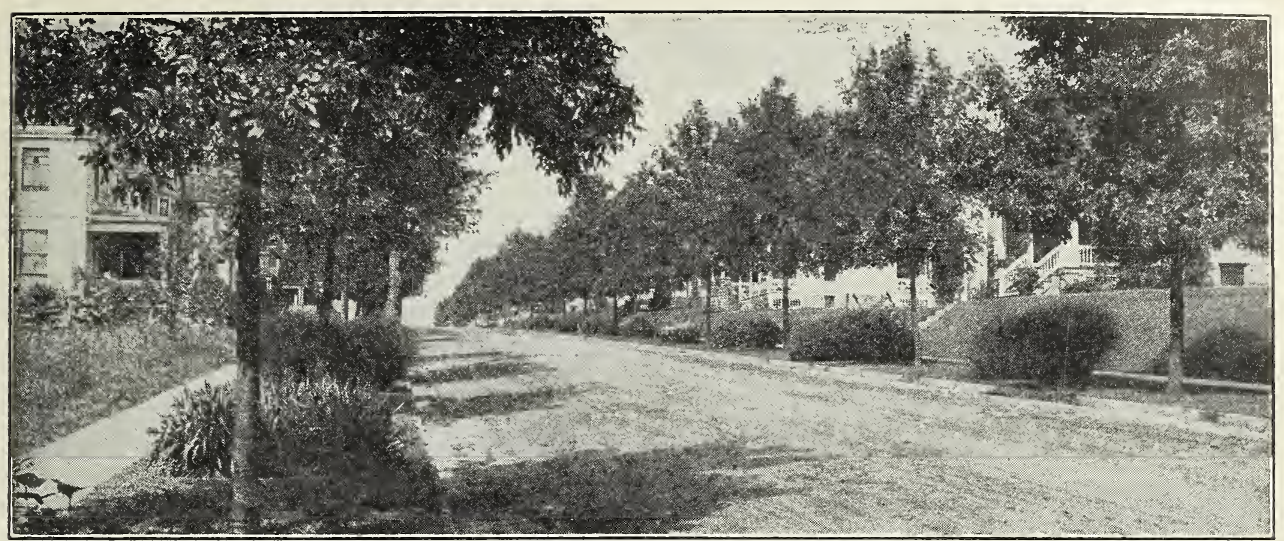

A Row of Norway and Silver Leafed Maples

Sugar or Rock Maple.-Probably the most generally used of all shade trees. Its Autumn tints are familiar to all.

Wier's Cut-leaved Silver Maple.-One of the most rapid and graceful growing of weeping trees, forming beautiful specimens in a short time. Foliage deeply cut and borne on long recurving, pendulous branches; can be pruned severely. Perfectly hardy.

\section{MAGNOLIA.}

Magnolia, Speciosa.-Showy, flowering Mag. nolia. A good grower, tree generally roundheaded and of fine form; flowers a little smaller and of a lighter color than those of Soulangeana, but being produced in wonderful profusion. This is one of the best varieties.

Acuminata Cucumber Magnolia.-A beautiful. native, pyramidal growing tree attaining from
60 to 100 feet in height. Leaves 5 to 8 inches in length, bluish green, flowers yellow, tinted with purple. Fruit when green looks like cucumber.

Conspicua Chinese White Magnolia.-A Chinese species of exquisite beauty. Medium size, shrub-like when young and with age grows higher. Flowers are large and numerous and pure white and come before the leaves.

Lenne.-(Lennei)-A very showy flower; cup-shaped; crimson purple outside and pearl colored within. One of the finest of the purple magnolias.

Soulange's Magnolia.-Stubby and branching while young. Flowers white and purple. Cup. shaped, 3 to 5 inches in diameter. Foliage large and waxy. One of the finest of the Chinese rarieties.

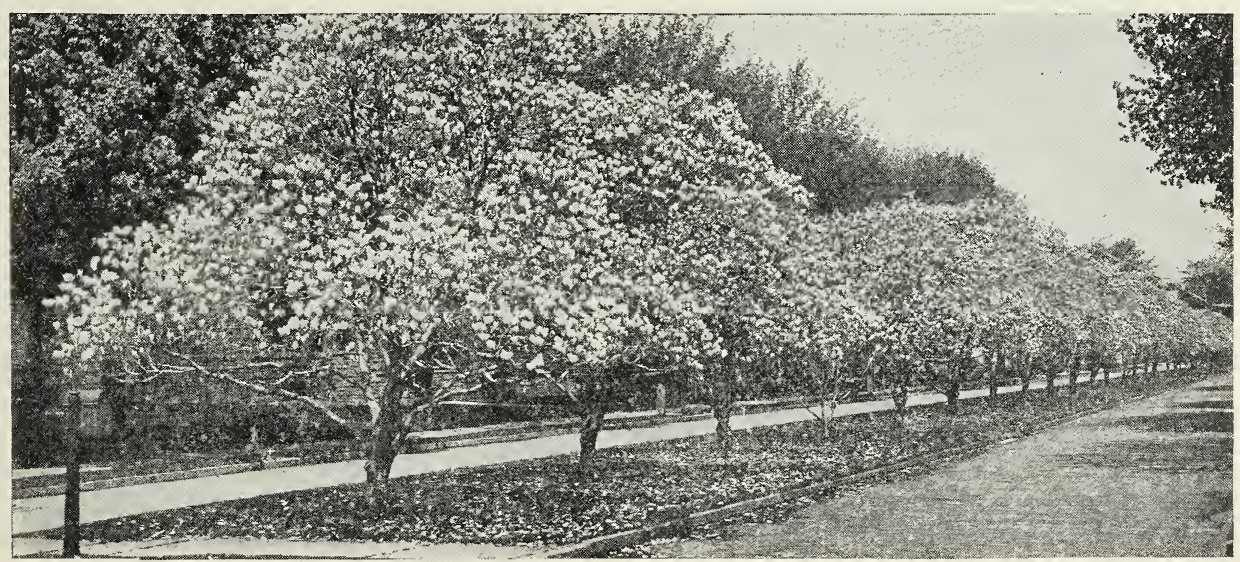

Chinese White Magnolia 


\section{BROWN BROTHERS COMPANY, ROCHESTER, N. Y.}

\section{MOUNTAIN ASH-Sorbus.}

American.-A favorite, erect-growing tree, of medium size, producing white flowers early in spring, followed by clusters of bright scarlet berries, which remain on the tree through the winter months.

European.-Similar in appearance to American, with finer foliage, and smaller, deepercolored berries from July to Winter, much more desirable than the American, and everywhere very popular. When fully grown, 20 to 35 feet.

Oak-leaved.-A very distinct and desirable tree, with compact, pyramidal head and darklobed leaves, downy underneath; producing the same flowers and berries as suropean. Tery hardy and desirable for planting on lawns or in dooryards.

Weeping European.-(See Weeping Trees).

\section{MULBERRY-Morus.}

The Mulberry is valuable both as an ornamental shade tree and for its fruit. It is of easy culture, requiring little or no pruning.

Downing's Everbearing.-A rapid grower, bearing large, black, edible fruit from June until September. Leaves larger than other varieties.

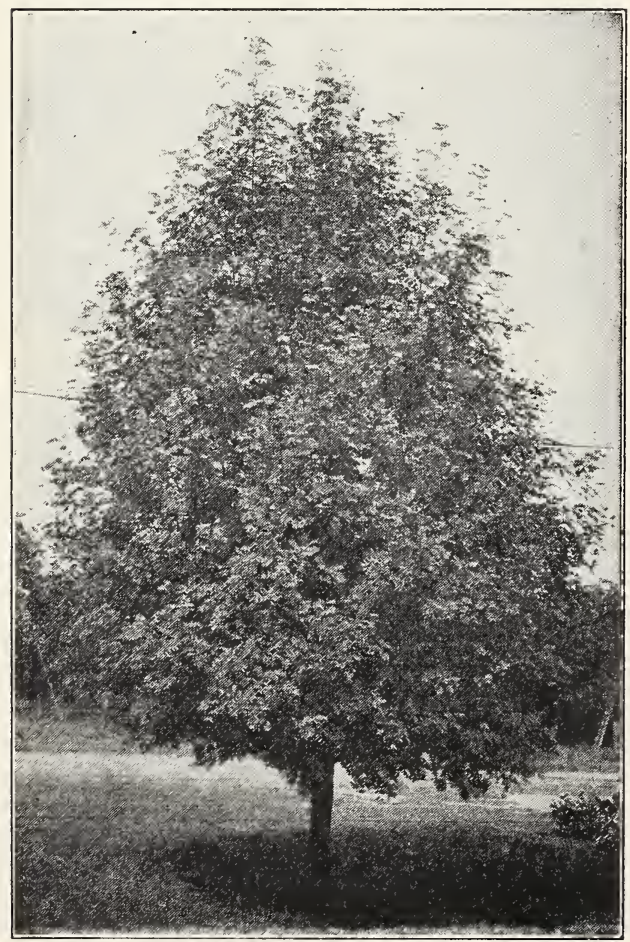

American Mountain Ash

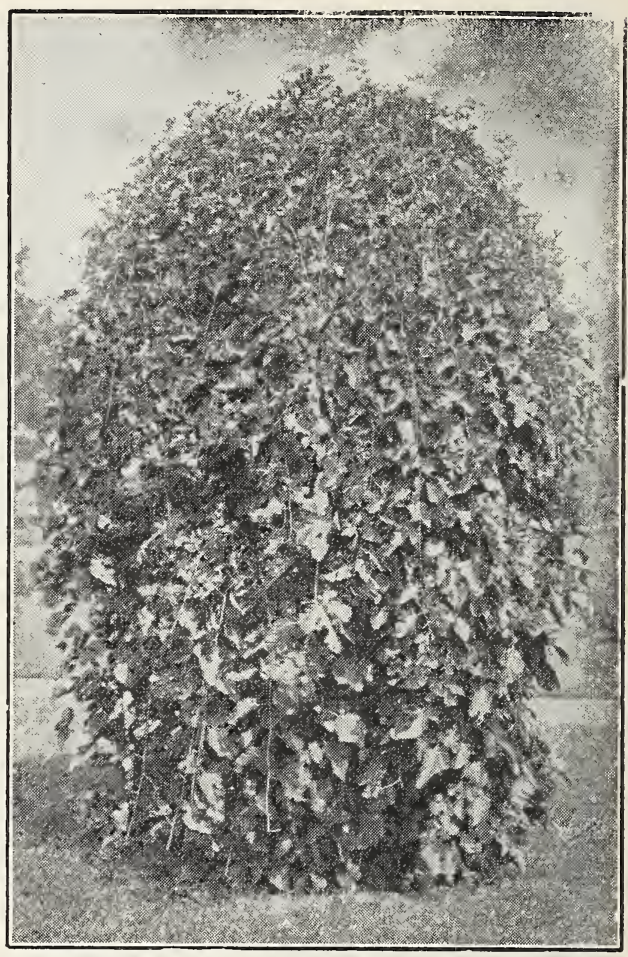

Mulberry, Tea's Weeping

Russian.-A very hardy, rapid-growing timber tree of great value, especially in the West. Introduced by the Mennonites; foliage abundant and said to be very desirable in the culture of silk worms. Fruit of good size and produced in great abundance.

\section{Tea's Weeping Russian Mulberry.-(See Weeping Trees).}

White Mulberry.-The silk-worm mulberry. Makes a large, spreading tree; fruit pinkish white.

\section{OAK-Quercus.}

The Oaks, when they attain size, are our most picturesque trees. The species and varieties are numerous, and the majority are adapted to ornament large grounds where they can have an abundance of room.

Pin.-The Pin Oak is undoubtedly the most valuable variety for all practical purposes. The foliage is dense, finely divided, of a beautiful shining green that colors to sparkling red and yellow in fall. The tree is easily transplanted and grows well on wet or dry ground; is, in fact, the quickest growing of all the Oaks. As an avenue and street tree it is unequalled, and it is one of the best for park planting. 


\section{PEACH-Persica.}

The double flowered varieties are distinguished for their showy and beautiful bloom. At the blossoming season in May every branchlet is covered with a mass of beautifully formed, highly colored flowers, rendering the trees most interesting objects and attracting notice from a distance. The double red, double rose, and double white varieties, planted in a group, produce a charming effect.

Double White-flowered Peach.-Very ornamental. Flowers pure white and double; su. perb. Perfectly hardy.

Double Red-flowered Peach.-Flowers semidouble, bright red; superb.

Double Rose-flowered Peach.-Flowers double, pale rose-colored, like small roses. Very pretty.

\section{PLANE TREE-Platanus.}

Oriental Plane.-(Orientalis)-Leaves heart shape at base, deeply cut. Is among our tallest trees, growing rapidly into massive proportions. Hardy and free from disease. It does well in cities and near the seashore, and is not affected by insects.

Olive, Russian.-(Eleagnus)-A very large shrub or small tree; leaves narrow and silvery white, flowers, yellow and fragrant; very hardy.

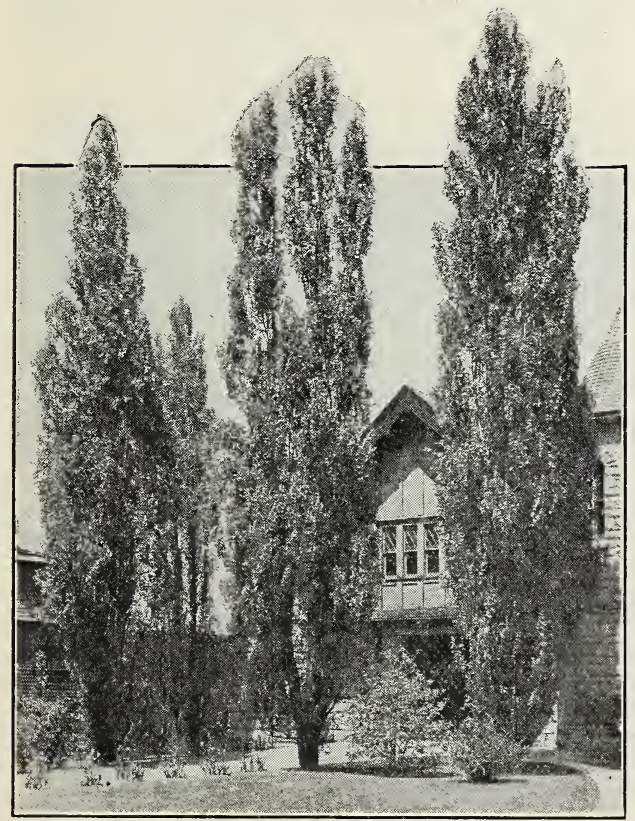

Lombardy Poplar
POPLAR-Populus.

Bolles' Poplar.-A very compact, upright grower, resembling the Lombardy Poplar, with leaves glossy green above and silvery beneath. A splendid tree.

Carolina Poplar.-Pyramidal in form and robust in growth; leaves large, glossy, serrated, pale to deep green. Valuable for street planting, also for screens. Very rapid grower.

Lombardy or Italian Poplar.-Attains a height of from 100 to 150 feet. Well known and remarkable for its erect, rapid growth and tall, spiry form. Indispensable in candscape gardening, to break the ordinary and monotonous outlines of most other trees.

Norway Poplar.-(Sudden Sawiog)-Tree very hardy; is being planted quite extensively in many sections. Similar to Carolina Poplar in growth and appearance, but is claimed to ve of more rapid growth and retains its size better as it mounts upward, and thus produces more lumber. Will thrive in most any soil or location. Valuable for s'sreet and park planting and also for screens and shelter belts.

White or Silver Poplar, or Silver Abele.From Europe. A tree of wonderfully rapid growth, and wide spreading habit. Leaves glossy green above and white as snow beneath.

Prunus Pissardii._(Purple Leaved Plum)The tree is a decided contrast in itself. The leaves as they first appear, on the tips are a veautiful orange color, and they mature to a rich purple, clear and distinct, growing darker as the season advances. The leaves remain until late in the fall-a decided contrast to other shrubs.

\section{SALISBURIA, MAIDEN-HAIR TREE OR GINRGO.}

A rare. beautiful tree from Japan, with remarkable fern-like foliage, distinct and fine. Especially desirable for planting on lawns or in dooryards. A rapid grower.

\section{THORN-Cratægus.}

The Thorns are among the most beautiful flowering trees. They are generally dense, low growers, occupying comparatively little space and well adapted to beautify small grounds. The foliage is varied and attractive, flowers very showy and of ten highly perfumed. The fruit is very effective and ornamental in autumn.

Double Scarlet.-(Coccinea fl. pl.)-Flowers deep crimson with scarlet shade; very double and considered larger than the double red; fine rich foliage.

Double White-(Alba flore pleno)-Has small double white flowers. 
BROWN BROTHERS COMPANY, ROCHESTER, N. Y.

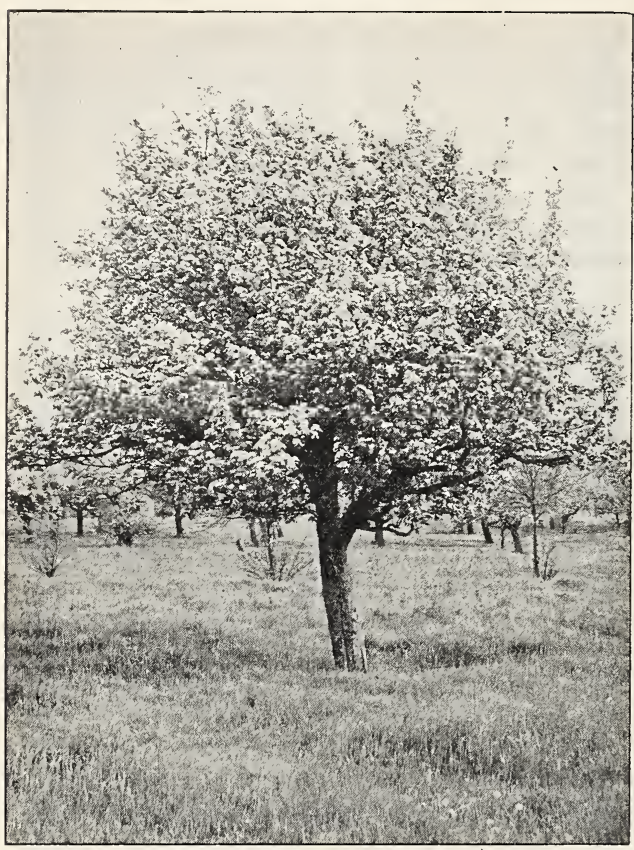

Paul's Thorn

Paul's Double Scarlet.-(Coccinea fl. pl. Paulii)-Flowers larger, deep carmine scarlet. superior to any other variety.

\section{TREE OF HEAVEN-Ailanthus.}

A Japanese tree, with long, feathery foliage, rapid grower, producing a tropical effect. Free from all diseases.

\section{TULIP TREE-Liriociendron.}

Tulipifera.-A magnificent native tree with broad, glossy, fiddle-shaped leaves and beautiful tulip like flowers; allied to the Magnolias, and like them difficult to transplant unless of small size.

\section{WILLOW-Salix.}

The Willows are a most useful and ornamental class of trees. Of rapid growth, fine habit, hardy, adapted to a great variety of soils, and easily transplanted, they can be used by planters to great advantage.

Willow, Wisconsin Weeping.-Of drooping habit and hardier than Babylonica. Valuable on account of its ability to resist severe cold.

Golden.-(Vitellina aurantiaca)-Very conspicuous on account of its yellow bark.

Kilamrnock Weeping Willow.-(See Weeping Trees).

Laurel-leaved Willow.-A fine ornamental tree, with very large, shining leaves.

Rosemary-leaved. (Ros m a rin if olia)Branches feathery, with small, silvery foliage; makes a striking, pretty, small-sized tree when grafted standard high. This, the Kilmarnock and the New American Weeping, should always find a place in every yard and garden, and will produce a pleasing effect. When fully grown, ten feet.

WALNOT-Juglans.

Black-English.—(See Nuts).

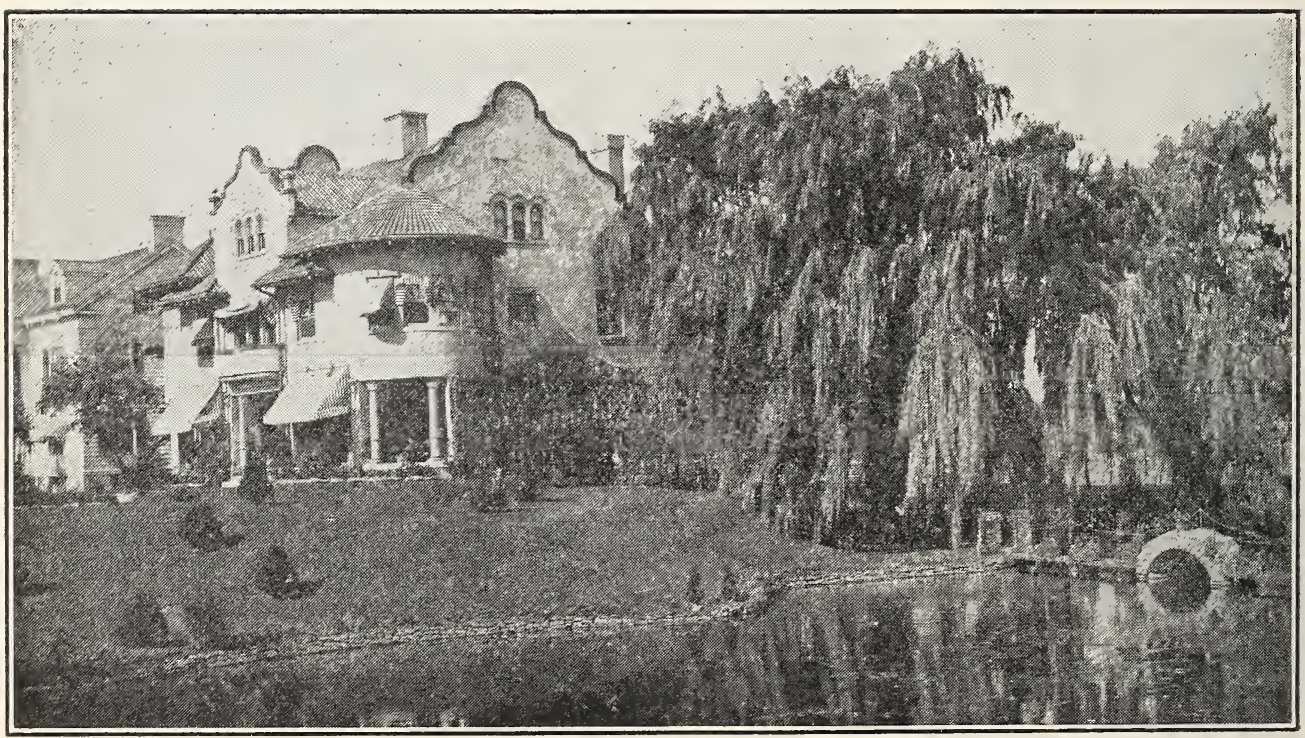

Wisconsin Weeping 


\section{WEEPING，OR DROOPING DECIDUOUS TREES}

MUCH attention is now given to this interesting class of trees. and we thereI fore place them separately for the greater convenience of our friends. For the benefit of those unacquainted with their habits, we would say that they should be divided into two separate classes, namely: those which are grafted where the top or head commences to form, as in the case of the Kilmarnock Willow, and those having long, slender branches which droop naturally, like the Cut-leaved Birch; the first assumes that conspicuous, umbrellalike form so well known, and so excellently adapted for planting in cemeteries, small yards and gardens. The latter have tall-growing trunks, with long slender branches, and are really handsome. They are adapted for larger places, where they can have sufficient room. In such situations, the elegance and grace of their branches in motion, or at rest, are so graceful to the eye that among ornamental shrubbery they have few if any superiors.

\section{ASH-Fraxinus.}

European Weeping.-(Excelsior Pendula)The common well known sort; one of the finest lawn and arbor trees, covering a great space and growing rapidly.

\section{BEECH-Fagus.}

Weeping.-(Pendula)-A native of Belgium; a fine, vigorous and beautiful tree, attaining a large size; though ungainly in appearance, when divested of its leaves, it is extremely graceful and effective when covered with its rich. luxuriant foliage.

\section{BIRCH-Betula.}

Cut-leaved Weeping.-(Pendula Laciniata)Extremely vigorous and hardy. Mr. Scott, in his "Suburban Home Ground," says of it: "No engraving can do it justice; like the plam tree of the tropics, it must be seen in motion, sway. ing in the lightest breeze, its leaves trembling in the heated summer air, its white bark glistening through the bright foliage and sparkling in the sun, to enable us to form a true impression of its character."

Young's Weeping. - (Youngii) - Originated near Milfred, England, where it was found trailing on the ground. Grafted into stems at some height, it forms pendulous heads drooping to the ground in fine, threadlike.shoots; very beautiful.

\section{CHERRY-Cerasus.}

Japan Weeping, Rose-flowered.-One of the finest pendulous trees for lawns or small grounds. The branches are slender, and fall gracefully to the ground, and the flowers are rose-colored, appearing before the leaves. Undoubtedly one of the finest weeping trees.

\section{ELM-Ulmus.}

Camperdown.-(Pendula)-Grafted six or eight feet high, this forms one of the most picturesque drooping trees. It is of rank growth, the slioots often making a zigzag growth outward and downward of several feet in a single season. The leaves are large, dark green and glossy, and cover the tree with a luxuriant mass of verdure.

\section{MOUNTAIN ASH-Sorbus.}

Weeping.-- (Ancuparia pendula)--The branches of this distinct variety are of a straggling, pendent character. turning and twisting in all directions and producing a very pleasing effect. Covered during the autumn with bright red berries.

\section{MULBERRY-Morus.}

Tea's Weeping.-The most graceful and hardy Weeping tree in existence. Wholly unlike anything heretofore introduced.

\section{WILLOW-Salix.}

Babylonica.-Our common well known weeping variety; forms a large, round-headed, graceful tree; requires plenty of room, and where space can be spared, is quite desirable.

Kilmarnock.-(Caprea pendula)-A distinct variety, having reddish shoots and large, glossy foliage; grafted at a proper height, about five feet from the ground, it makes a very desirable small lawn tree, having a perfect umbrellashaped head, with the branches drooping gracefully to the ground. It is well suited for planting in cemetery lots or small enclosures. Extensively planted, and should be in every collection of ornamental shrubbery. Hardy and of vigorous growth.

New American.-(Purpurea pendula)-An American dwarf variety, which when grafted on a standard stem, five or six feet high, makes one of the most ornamental of small weeping trees, having long, slender shoots and delicate leaves of great beauty and very graceful. 


\section{EVERGREENS-Coniferae}

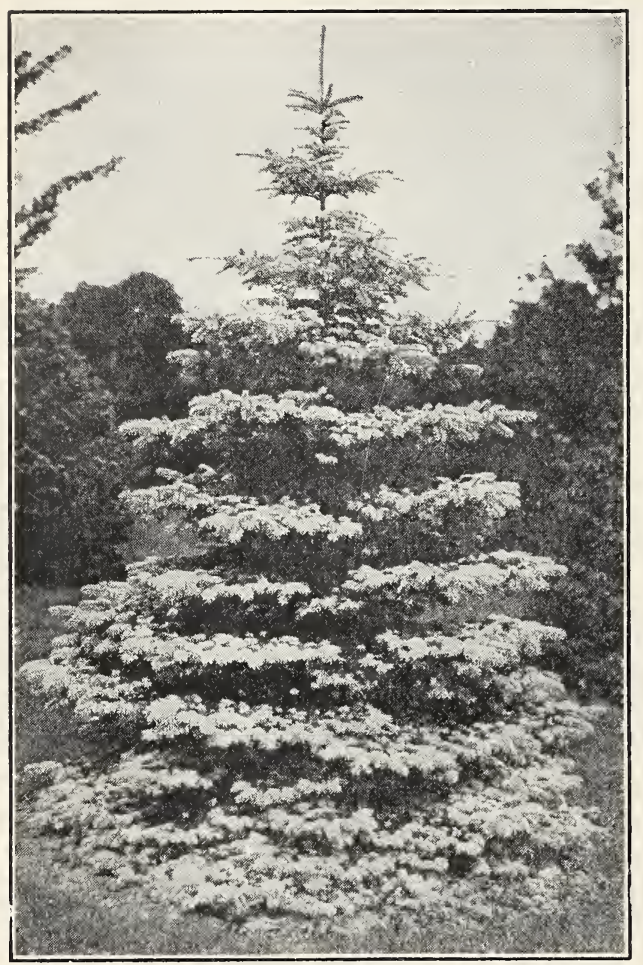

Colorado Spruce

\section{ARBOR VITAE-Thuja.}

American Arbor Vitae.-A native tree of extreme beauty. Known as the white cedar; especially valuable for hedges.

Pyramidal Arbor Vitae.-Grows upright with compact habit. Very desirable.

Siberian Arbor Vitae.-Claimed to be the best. Exceedingly hardy, grows compact and pyramidal, keeping its color all winter. Extra fine for hedges or screens.

Red Cedar.-A well-known American tree, with deep-green foliage; makes a fine ornamental hedge plant.

\section{FIR-Abies.}

Balsam Fir.-Erect, pyramidal tree with dark green sombre foliage. Grows rapidly and is very hardy. A pretty tree for lawns, cemeteries, parks, etc.

\section{HEMLOCK-Tsuga.}

Hemlock Spruce.-A beautiful and graceful native tree with drooping branches and dark delicate foliage of green. It makes a fine lawn tree or ornamental hedge.

\section{JUNIPER-Juniperus.}

Irish Juniper.-A distinct and beautiful variety, erect and dense. Resembles a pillow of green. Very fine.

\section{SPRUCE-Picea.}

White Spruce.-A native tree of medium size and of pyramidal form. Foliage silver gray and light colored bark. Leaves needleshaped. Hardy.

Norway Spruce.-An elegant tree; extremely hardy, of lofty, rapid growth and pyramidal form. The branches assume a graceful, drooping habit when the tree attains 15 to 20 feet in height. One of the most popular evergreens for planting, either as single specimen trees, or in masses for effect or shelter. It is one of the best evergreen hedge plants. A European tree.

Colorado Blue Spruce.-One of the hardiest and most beautiful of all the Spruces; in form and habit similar to the White Spruce; foliage of a rich blue or sage color.

Koster's Blue Spruce. - Similar to the preced ing, except that the foliage is a much brighter blue. Very rare.

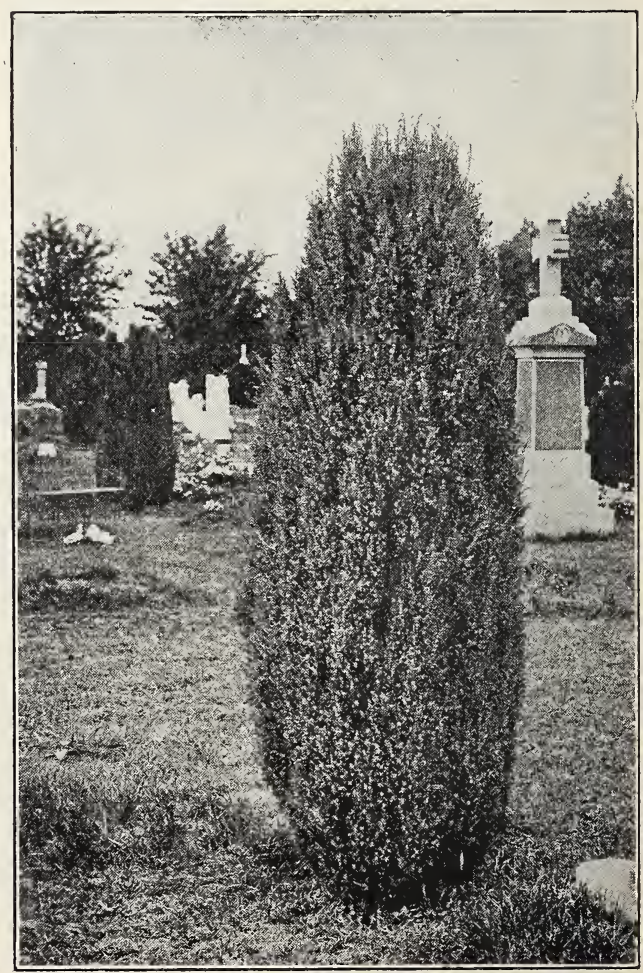

Irish Juniper 


\section{PINE-Pinus.}

Austrian or Black Pine.-Tree remarkably robust, hardy and spreading; leaves long, stiff and dark green; growth rapid. The most valuable for this country.

Dwarf Mugho Pine.-An upright, small pine. Its general form is that of a pine bush.

White or Weymouth Pine.-The most ornamental of all our native Pines; foliage light, delicate or silvery green. Flourishes in the poorest light sandy soil.

Scotch Pine or Fir.-A native of the British Islands. A fine, robust, rapid growing tree. with stout, erect shoots, and silvery green foliage. Very hardy.

\section{RETINOSPORA OR JAPAN CYPRESS.}

A genus very similar to Cupressus. It comprises many sorts of wonderful beauty. They are natives of Japan and very few will endure the rigor of our winters without protection. Whenever they can be preserved they will amply repay the efforts made. The small varieties are exceedingly desirable for in-door culture in pots.

Filifera.-Thin-branched Japan Cypress. A low tree with irregular outline and very elegant appearance. Its long drooping foliage and pretty form are very pleasing

\section{YEW-Taxus.}

Canadian Yew D.-A native Yew of low spreading habit; quite hardy.

Japanese Yew.-One of the hardiest; habit spreading; foliage light green.

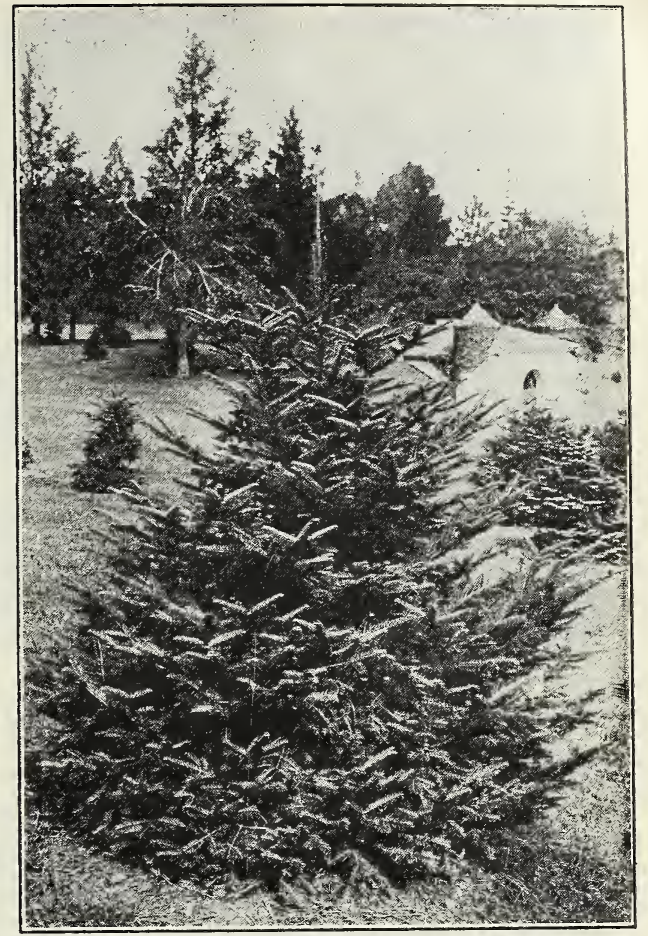

Balsam Fir

Improve the Value of Your Property by Planting Appropriate

Shrubbery and Ornamentals

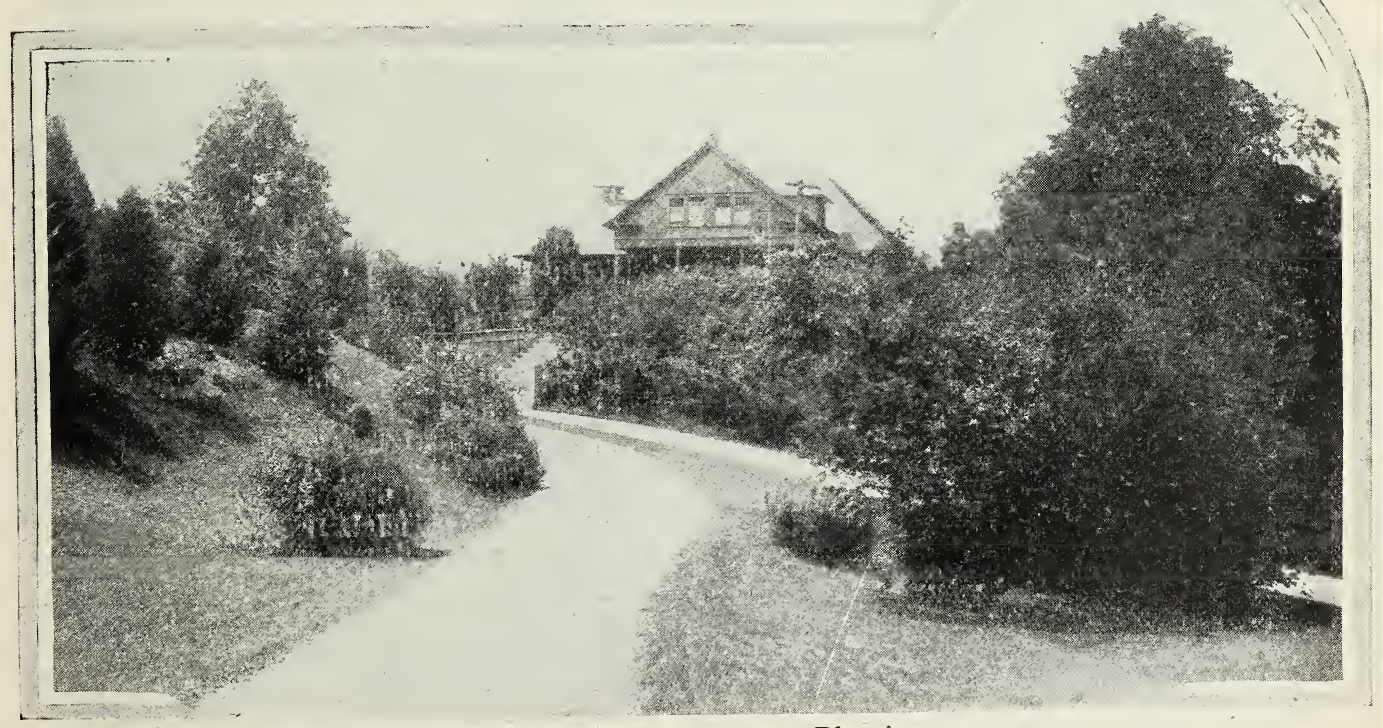

An Attractive Evergreen Planting 
BROWN BROTHERS COMPANY, ROCHESTER, N. Y.

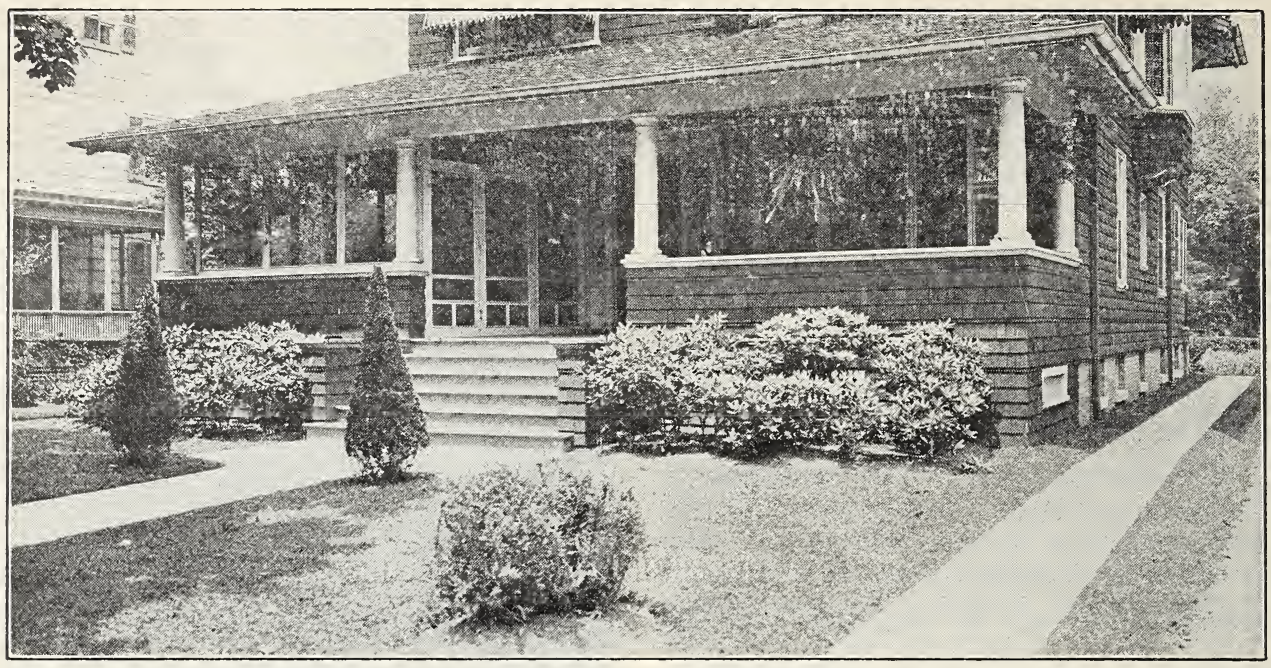

Conifers

Deutzia

Rhododendron

\section{DECIDUOUS HEDGE PLANTS}

To secure a good hedge it is necessary to plant well. Dig a wide, deep trench, and work the soil thoroughly into the roots. Stamp the ground firmly so that each plant will be set as solidly as a post, then mulch heavily with loose manure for a distance of one to two feet on either side. according to the size of the plants. This is especially necessary with Evergreens, and all exposure of the roots tothe sun and air must be strictly avoided. Evergreens should not be planted in the Fall.

\section{HONEY LOCUST.}

Very hardy and the cheapest and the best for defensive hedges; also very ornamental.

\section{JAPAN QUINCE.}

Unquestionably the finest of all plants for an ornamental hedge. Grows very compact; will submit to any amount of pruning, while the brilliant and showy scarlet flowers make it very attractive.

\section{OSAGE ORANGE.}

Highly esteemed at the West and South. Not hardy enough for the Northern States.

\section{PRIVET-Ligustrum.}

California.-(Ovalifolium)-This is the most glcssy-leaved and rapid growing of all the halfevergreen plants used for low hedges around private lawns, and is the universal favorite at Newport and other fashionable seaside resorts.

The following are also very desirable for ornamental hedging, description of which will be found under the proper headings in this catalogue:

Altheas,

Barberry,

Hydrangea Paniculata,

Honeysuckle Tartarian, Roses,

\section{EVERGREEN HEDGE PLANTS.}

All described in their appropriate places in this catalogue.

Arbor Vitae, American, Arbor Vitae, Siberian, Box, Dwarf, for Edging. Hemlock Spruce, Norway Spruce (especially adapted for windbreaks).
Arbor Vitae, Compacta.-A dwarf compact variety with a conical head; of bright green color, perfectly hardy. A native of Japan.

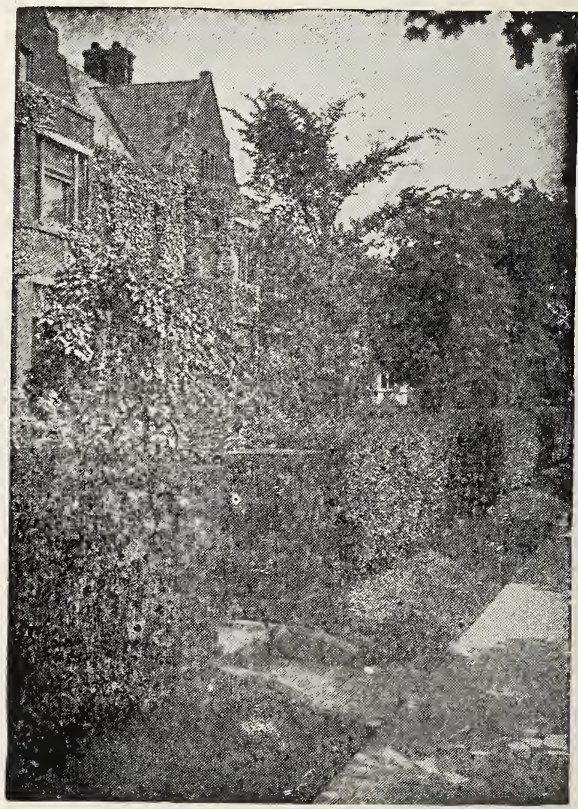

California Privet 


\section{FLOWERING} TRAILING.

THOSE who desire flowers about their home lawn and garden during the summer-blooming from April to October-may select from the following list. The varieties flower in the order named.

APRIL-Daphne mezereum.

MAY-Forsythia in variety, Japan Quince, Prunus Pissardi, Prunus triloba, Almond, Spirea prunifolia flore pleno, Lilacs, Spirea Van Houttei, Viburnum lantana, Mahonia, Honeysuckle, Wistaria.

JUNE-Deutzia gcacilis, Deutzia Lemoineii, Spirea lanceolata, Viburnum opulus, Weigela, Cornus alba, Lilac Japonica, Hydrangrea arborescens grandiflora alba, Syringa, Rhododendrons, Paeonies Herbaceous, Clematis Jackmanni, Elder, Deutzia, Pride of Rochester.

JULY-Spirea Billardii, Spirea Anthony Waterer.

AUGUST AND SEPTEMBER-Althaea, Hydrangea paniculata mranditora. Clematis paniculata.

The following shrubs will grow well in shady places: Barherry. Bux, Ceanothus, Cornus, Deutzia, Forsythia, Honeysuckle, Kalmia, Mahonia, Myrtle, Privet, Rhododendron, Rhus, the Virburnums, Yew.

\section{UPRIGHT DECIDUOUS SHRUBS}

\begin{abstract}
ALMOND-Amygdalus.
Double Rose Flowering. - (Japonica rubra fl. pl.)-A beautiful small shrub, bearing in May, before the leaves appear; small, double, rose-like flowers, closely set upon the twigs.

Double White Flowering.-(Japonica alba fl. pl.)-Produces beautiful white flowers in May.

\section{ALTHEA OR ROSE OF SHARON- Hibiscus.}

These are fine, hardy, free-growing and
\end{abstract} flowering shrubs, blooming in August and September, when few plants are in blos. som. They attain a height of 6 to 10 feet.

Double Red.-(Rubra flore pleno.)

Double Purple.-Purpurea flore pleno.)

Double White.-(Alba flore pleno.)

Variegated-leaved Double Purple Flowered Althea.-A conspicuous variety with the foliage finely marked with light yellow, and producing double purple flowers. One of the finest variegated-leaved shrubs.

\section{ANGELICA TREE-Aralia.}

A pretty Japanese shrub, of medium size and rapid growth; branches furnished with spines; leaves pale green.

\section{AZALEA.}

Splendid hardy species from Japan, and one of the most valuable flowering shrubs. Flowers large and showy, yellow and different shades of red, in fine trusses. For spring planting.

In selling Azaleas the selection of colors must be left entirely with us.

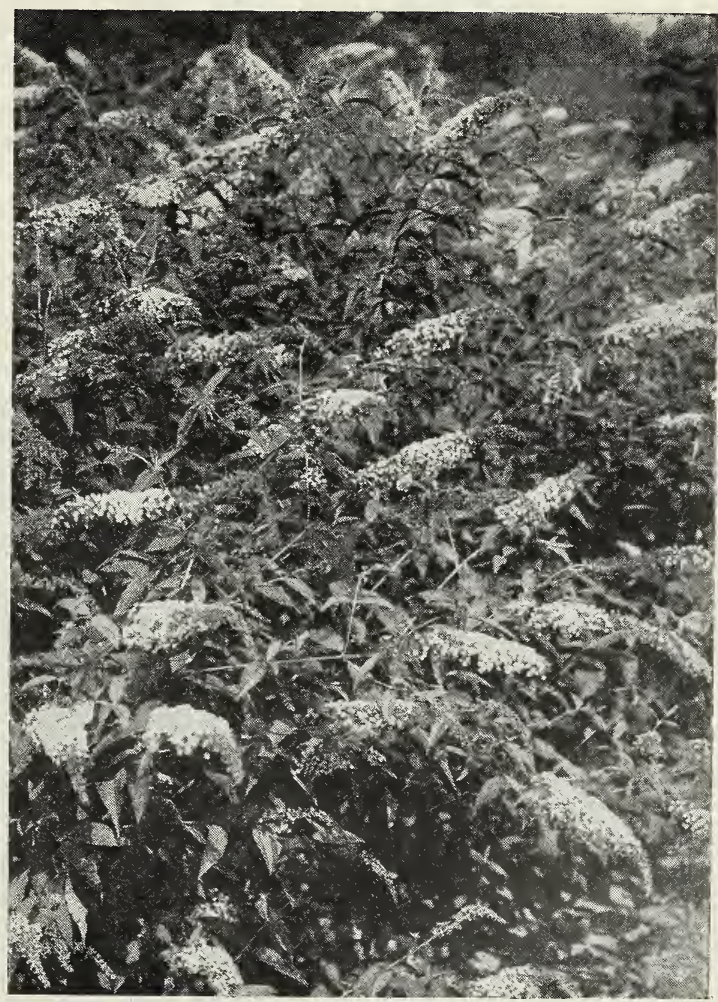

Buddleia-(Butterfly Bush or Summer Lilac) 


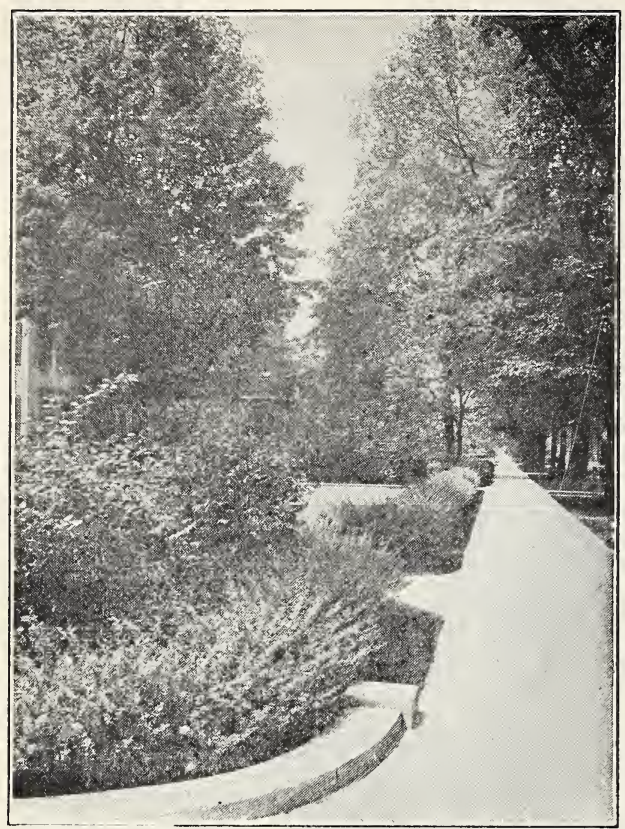

Thunberg's Barberry

\section{BERBERIS-Barberry.}

The Barberries are a most interesting family of shrubs, varying in size from 2 to 6 feet high, rich in variety ot leaf, flower and habit. The orange and yellow flowers in May or June are succeeded by bright and vari-colored fruit; very ornamental in the latter part of the year.

Common Barberry.-European Barberry.A handsome deciduous shrub, with yellow flowers in terminal drooping racemes in May or June, followed with orange scarlet fruit.

Purple-leaved Barberry.-An interesting shrub, growing 3 to 5 feet high, with violet. purple foliage and fruit; blossoms and fruit beautiful; very effective in groups and masses, or planted by itself.

Thunberg's Barberry.-From Japan. A pretty species, of dwarf habit, small foliage, changing to a beautiful coppery red in autumn. Valuable as an ornamental hedge.

Cornus Mascula Variegated.-(Variegated Cornelian Cherry)-A small tree or shrub producing clusters of bright yellow flowers early in spring before the leaves appear. Has beautiful foliage variegated with white. Decidedly the prettiest variegated shrub in cultivation.

Butterfly Bush.-(Buddleya Variabilis Magnifica)-The name Butterfly Bush was applied to it because it seems to attract butterflies in large numbers. This shrub from a young plant set out either in the spring or fall, will mature to full size the first summer, produc- ing a handsome bush, which the first year often maintains a height of four feet. It produces long, graceful stems, which terminate in tapering panicles of beautiful lilac-colored flowers that are of miniature size and borne by the hundreds on a flowerhead, which is frequently ten inches long. A single plant the first season will throw out as many as 50 flower spikes, which increase greatly in number during the succeeding years. The year after planting it generally commences to flower in June and continues each season until the severe frosts nip it. The foliage and blooms are exceedingly fine. The shrub is semi-herbaceous, by which we mean that in some latitudes it will die down to the ground and while perfectly hardy, we recommend covering the roots with manure, leaves or other suitable material as winter approaches, as this will produce a heavy growth the following season. This shrub is very desirable as an individual specimen in the lawn and garden or placed promiscuously in the shrubbery border.

\section{CALYCANTHUS OR SWEET-SCENTED \\ SHRUB.}

The Calycanthus is one of the most desirable shrubs. The wood is fragrant, foliage rich, flowers of a chocolate color, having an agreeable odor. They blossom in June and at intervals afterwards.

\section{CLETHRA.}

Alnifolia.-(White Alder)-A native shrub of low and dense growth; leaves abundant and light green; has numerous spikes of small, white fragrant flowers. Blooms abundantly in July.

\section{CURRANT-Ribes.}

The flowering currants are gay, beautiful shrubs in early spring, and of the easiest culture.

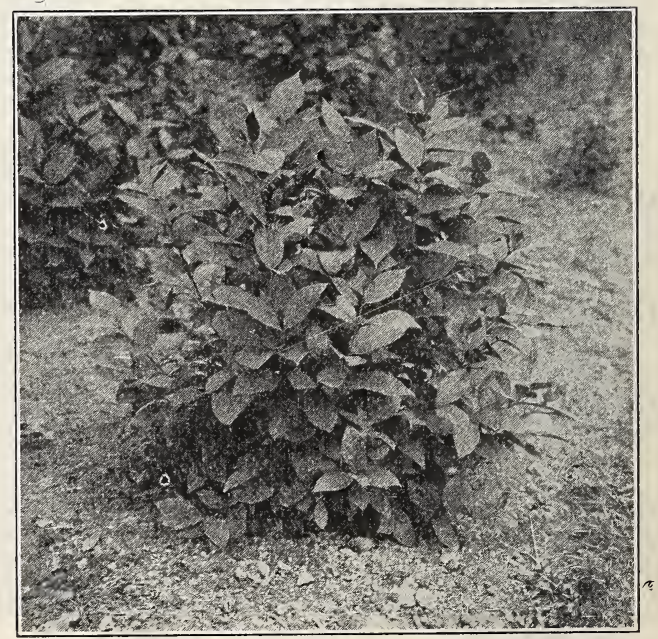

Calycanthus or Sweet-scented Shrub 


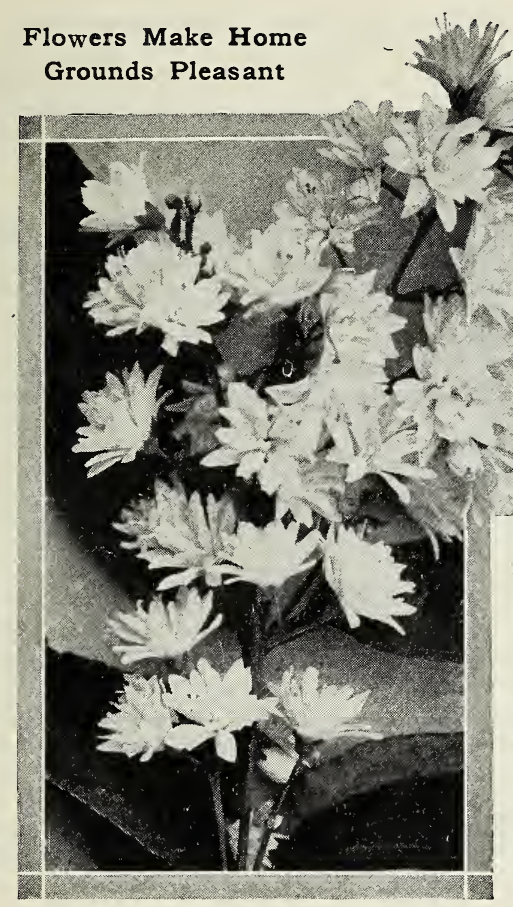

Deutzia_Pride of Rochester
Yellow-flowered, or Missouri Currant.-A native species with glabrous, shining leaves and yellow flowers.

Crimson-flowered Currant.-An American species with deep red flowers, produced in great abundance in early spring.

\section{DOGWOOD-Cornus.}

Red-branched Dogwood.-Very ornamental and conspicuous in winter while the bark is blood red.

Elegantissima Variegata.-A variegated shrub of rapid growth with broad leaves with white margins. Bark red in winter.

\section{DIUTZIA-Deutzia.}

Their hardihood, fine habit, luxuriant foliage, and profusion of attractive flowers, render the Deutzia among the most beautiful and deservedly the most popular of flowering shrubs at the present time.

Crenata.-(Double-flowered Deutzia)-Flowers double white, tinged with rose. One of the most desirable flowering shrubs in cultivation.

of

Rochester."

Excels

in

many

ways.

Lemoineii.--A hybrid obtained by crossing the well-known Deutzia fracilis with Deutzia parviflora. Flowers pure white, bordering on stout branches, which are of upright growth. Habit dwarf and free-flowering.

Gracilis.-(Slender-branched) - A charming species of dwarf habit, introduced from Japan by Dr. Siebold. Flowers pure white. Fine for pot culture, as it flowers freely in a low tem. perature in the winter. The first to flower, about the middle of June.

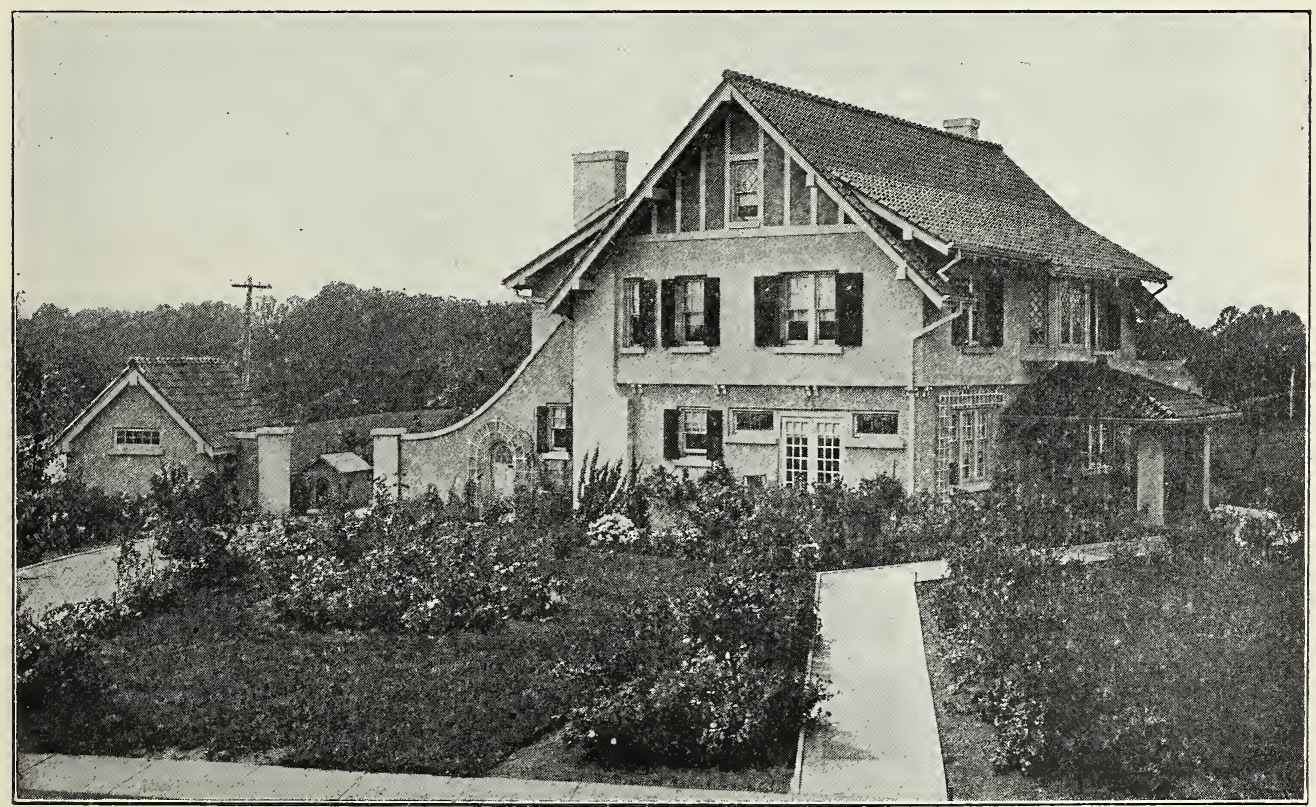

$A$ beautiful and effective planting can be made at small cost by a judicious selection of our hardy Shrubs 


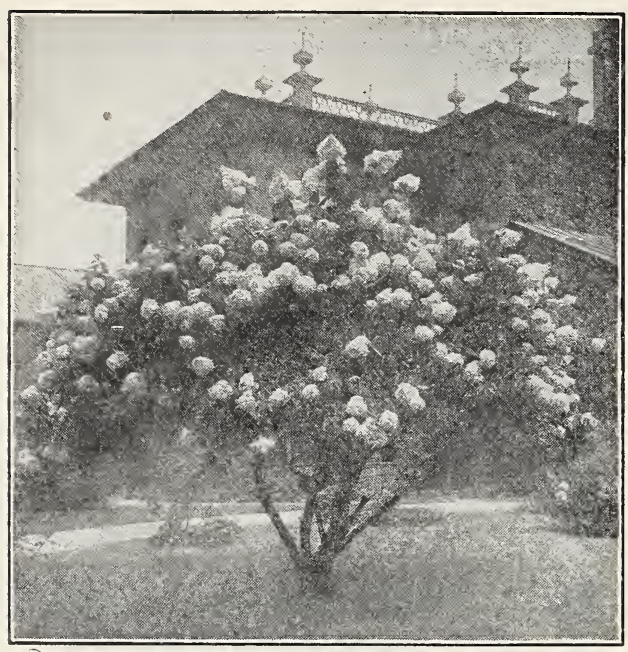

Hydrangea Paniculata Grandiflora

Deutzia Crenata Magnifica.-Of a vigorous habit, producing quantities of large, pure, white flowers in great trusses, the flowers as large as one and a quarter inches in diameter. It is a beautiful variety and very showy when in bloom. A novelty of great merit.

Pride of Rochester.-A variety raised by us and producing large double white flowers, the back of the petals being slightly tinted with rose. It excels all the older sorts in size of flower, length of panicle, profuseness of bloom and vigorous habit; blooms nearly a week earlier than Deutria crenata flore plerio.

Scabra.-(Ro igh-leaved)-One of the most beautiful profuse flowering shrubs; flowers single white.

\section{ELDER-Sambucus.}

Common American Elder.-Broad panicles of white flowers in June; reddish purple berries in autumn. A well-known native shrub.

Cut-leaved American Elder.-A beautiful variety, with deeply and delicately cut dark green foliage. It is vaiuable on account of its beauty, hardiness, and rapid growth, and the ease with which it is transplanted. We consider it one of the best cut-leaved shrubs in cultivation.

Golden.-(Aurea)-A beaut..ul variety with light vellow leaves, which hold their color well and render the plant very conspicuous and effective.

Euonymus.-(Burning Bush or Strawberry Tree)-A very ornamental and showy bush, whose chief beauty consists in its brilliant berries, which hang in clusters from the branches until mid-winter; berries rose-colored; planted with a background of Evergreens the effect of contrast is very fine.
Eleagnus Longipes.-A well-known shrub of spreading habit, dark green foliage, silverywhite beneath, with yellow flowers and bright red fruit that is beautiful as an ornament on the bush and is esteemed very highly by many for use in place of cranberries.

\section{FRINGE-Rhus.}

Filbert, Purple-leaved.-(Corylus avellana atropurpurea)-A vigorous shrub with large deep purple leaves; very ornamental; produces good fruit.

Purple Fringe, or Smoke Tree.-(Rhus Cotinus)-A small tree or shrub, very much admired on account of its peculiar fringe or hairlike flowers, covering the whole surface of the bush in mid-summer.

White.-(Chionanthus Virginica)-One of the finest shrubs with large leaves and racemes of delicate fringe-like greenish white flowers, in May and June.

\section{GOLDEN BELL-Forsythia.}

These are pretty shrubs of medium size. All natives of China and Japan. The flowers are drooping, yellow, and appear very early in spring before the leaves. The best very early flowering shrubs.

Fortune's Forsythia.-Growth upright, foliage deep green, flowers bright yellow.

Viridissima.-A fine hardy shrub. Leaves and bark deep green, flowers deep yellow, very early in spring.

\section{HALESIA}

Halesia (Snow Drop Tree).-Silver Bell. A beautiful large shrub with handsome white bellshaped flowers in May. Very desirable.

\section{Spirea.}

HONEYSUCKIE, UPRIGHT-Lonicera.

The following species and varieties are of erect, shrubby habit, and form beautiful specimens when properly trimmed:

Red Tartarian.-A well known old fashioned sort which blooms in May. It has slender and upright branches, with small bright pink flowers followed by red or orange yellow ber

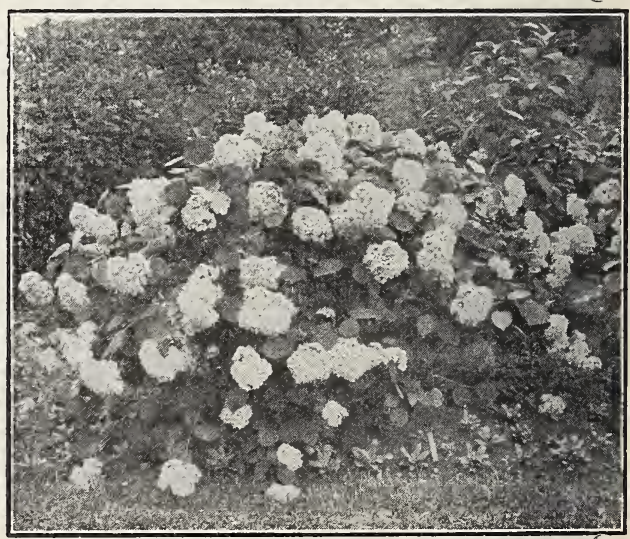

Hydrangea 
White Tartarian.-Same as the Red Tartarian, except in its beautiful white flowers, for reason of which it is fine for planting with other varieties for contrast.

\section{HYDRANGEA.}

Beautiful free flowering shrubs, bearing immense panicles or trusses of flowers. Paniculata and Arborescens are hardy and require no protection; the other varieties require protection in winter and should be grown in pots or boxes and wintered in the cellar.

Arborescens Grandiflora Alba.-(Hills of Snow)-This hardy American shrub is the very finest addition to this class of plants found in many a year. The blooms are of the very largest size, of pure snow-white color, and the foliage is finely finished, lacking entirely the coarseness found in Hydrangea pan. iculata grandiflora. One of its most valuable characteristics is its coming into bloom just after the passing of all the early spring shrubs, while its long season of bloom, from early June through August, renders it doubly valuable, not only to the florist, but to every owner of a garden; perfectly hardy, standing 20 degrees below zero. The form of the panicle is much like that of Hydrangea Hortensia."

Otaksa.-A splendid variety from Japan. Flowers large, bright pink, tinted with blue; produced very freely. Not hardy.

Paniculata Grandiflora.-This is one of the most valuable hardy shrubs. It attains a height of three or four feet, and is perfectly hardy in all parts of the country. The flowers are white, borne in immense panicles nearly a foot in length. It commences flowering in July and continues until November. The plant should be cut back every spring at least onehalf of last season's growth, as the flowers are borne on new wood and are much finer when the plant is treated this way. An excellent shrub for cemetery planting.

Thomas Hogg.-Immense trusses of flowers, at first slightly tinged with green, becoming of

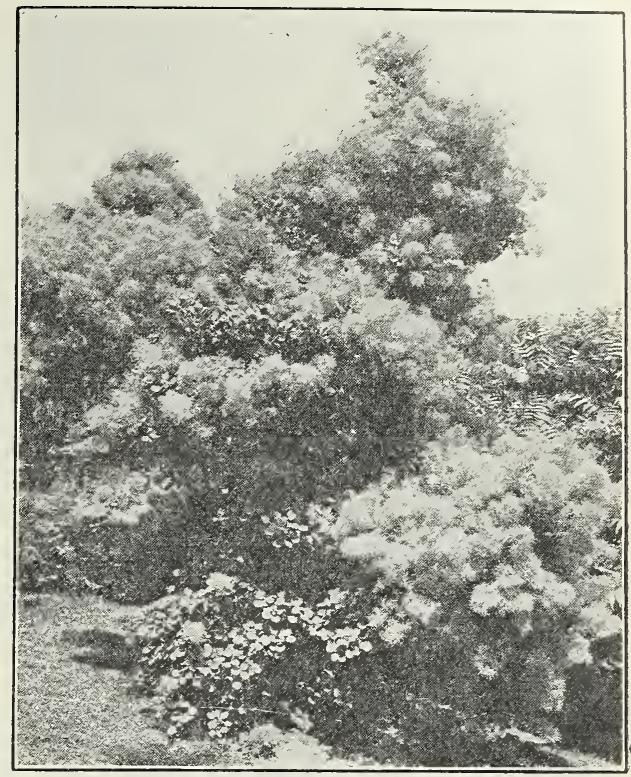

Purple Fringe, Smoke Tree

the purest white, and remaining so a long time. Not hardy.

Tree Hydrangea.-(Paniculata Grandiflora)In tree form. Beautiful as a shrub, they are grandly heautiful as a tree, growing in loveliness as they acquire age and size.

\section{RERRIA-Corchorus.}

Japonica.-(Japan Corchorus)-A slender green-branched shrub, with globular, yellow flowers from July to October.

Flore Pleno.-(Double-flowered Corchorus) Of medium size; double yellow flowers.

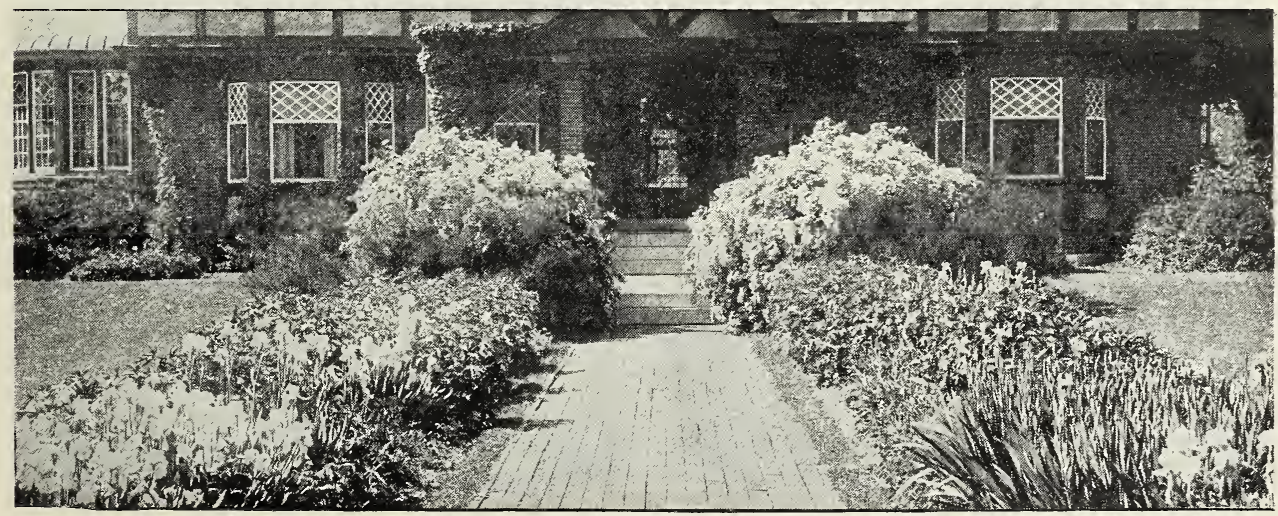

Showing how an Entrance to a Residence can be Artistically Planted with Spirea and Iris 


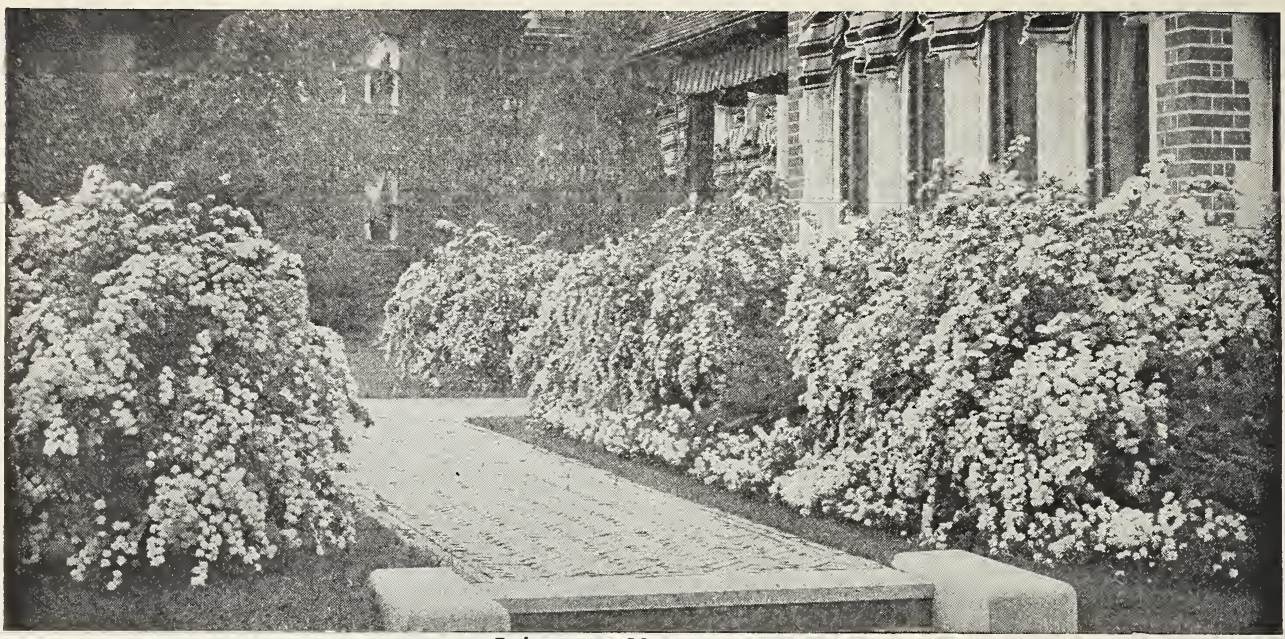

LILAC-Syringa.

Well-known, beautiful shrubs, indispensable in every collection. They flower in May.

Charles X.-Reddish purple.

Frau Dammann.-This is the best white lilac grown. The panicle or truss is immense, flowers of medium size and pure white. This and Ludwig Spaeth are the two best lilacs of recent introduction.

Lilac, Leon Simon.-Very large, rosy lilac.

Lilac, Weeping.-(New)-A beautiful weeping tree; produces large clusters of beautiful, intensely sweet flowers. A great acquisition.

Japan Tree.-A remarkable new specie from Japan, becoming a good-sized tree; foliage dark green, glossy; flowers small, feathery, but formed in great panicles, often 18 inches long, very light straw color; blooms a month later than other lilacs.

Ludwig Spaeth.-New, and believed to be the finest of its class. Color purplish red. A great acquisition.

Large Flowering White.-(Alba Grandiflora) - Very large: pure white tufts of flowers.

Marie Le Graye.-A free grower, producing magnificent large trusses of purest white flowers, which are very fragrant and showy. Highly recommended as perhaps the best of the white lilacs.

Madame Lemoine.-New and very promising. Flower double white.

Persian, Purple or White.-Foliage resembles the Privet more than the lilac. Flowers are most abundant.

FRAGRANT SNOWBALL-Viburnum Carlesii.

A recent introduction from Korea, producing delicate, spice-scented flowers in May and June. The buds before expanding are an attractive pink, developing into Bouvardia-like umbrels of pure white. Flowers preserve their perfect form and purity of color an unusually long time. Vies with the Daphne in point of fragrance; in fact it is the most sweetly scented shrub in cultivation as well as one of the most beautiful. Plant is of dwarf, bushy habit.

Japan.-(Viburnum Plicatum)-A rare and exceedingly beautiful species from Japan, surpassing the Common Snowball in many respects, as its habit is much better, foliage much handsomer, flowers whiter and more delicate. Very valuable.

Opulus.-(High Bush Cranberry)-Flowers in large, flat heads in latter part of May, followed by brilliant scarlet fruit in showy pendulous branches that remain on the plant all winter.

\section{SNOWBERRY-Symphoricarpus.}

Racemosus.-A well-known shrub with pink flowers and large white berries that remain on the plant through part of the winter.

Purple Common.-(Vulgaris) - The wellknown sort.

\section{PLUM-Prunus.}

Double-flowered.-(Prunus Triloba)-Native of China. A highly interesting and desirable addition to hardy shrubs; flowers double, of a delicate pink, upwards of an inch in diameter, thickly set on the long, slender branches; flowers in May.

\section{QUINCE-Cydonia.}

There are several flowering varieties, differing only in their color. Although of straggling growth, they can be pruned to desirable shapes without injury. Their large brilliant blossoms appear early in the spring in great profusion. Foliage bright green and glossy all through the summer. It is sufficiently thorny and strong to make a valuable hedge, and its beautiful flowers make it very handsome for that purpose.

Scarlet.-(Japonica)-One of the best known, and a very handsome, hardy shrub.

Vulgaris.-(Indian Currant, Coral Berry)Graceful, small shrub, small flowers followed by persistent deep-red berries along the underside of branches. 


\section{SPIRAEA, OR MEADOW SWEET.}

The Spiræas are all elegant, low shrubs, of the easiest culture, and their blooming extends over a period of three months.

Anthony Waterer.-A beautiful variety with broad heads of deep pink flowers. Grows two to three feet high, making a shapely bush. Blooms almost continuously from June throughout the season.

Billard's Spiræa. - Rose colored. Blooms nearly all summer.

Blue Spiraea.-(Caryopteris Mastocanthus) -A fine low-growing shrub, from China, from 2 to 3 feet; blooms during entire season and late in the fall.

Callosa Alba.-A white flowering variety of dwarf habit; very fine; remains in flower all summer.

Prunifolia, or Bridal Wreath.-Very desirable, having double, daisy-like flowers of pure white in the greatest profusion. Very hardy and in every way desirable, as it keeps in flower a long time.

Reevesii.-A charming shrub, with narrow, pointed leaves, and large round clusters of white flowers that cover the whole plant.

Thunberg's Spiræa.-Of dwarf habit and rounded, graceful form; branches slender and somewhat drooping; foliage narrow and yellowish green; flowers small, white, appearing early in spring, being ore of the first Spiræas to flower. Esteemed on account of its neat, graceful habit.

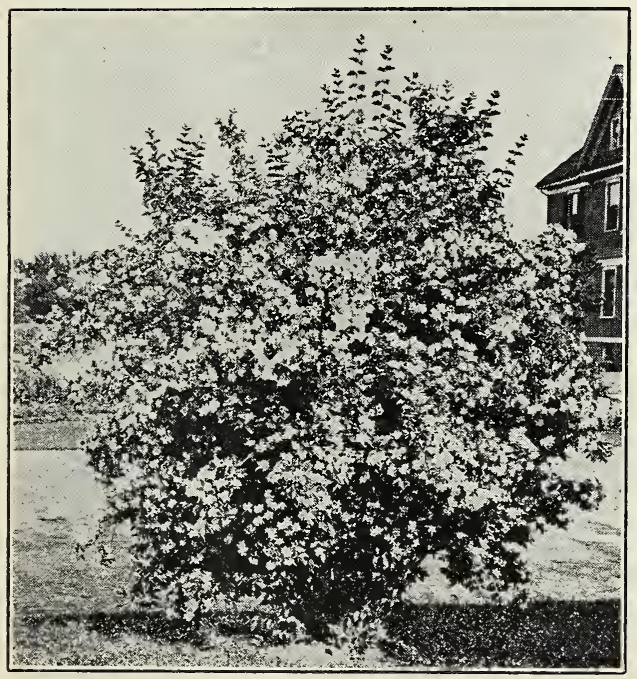

Mock Orange

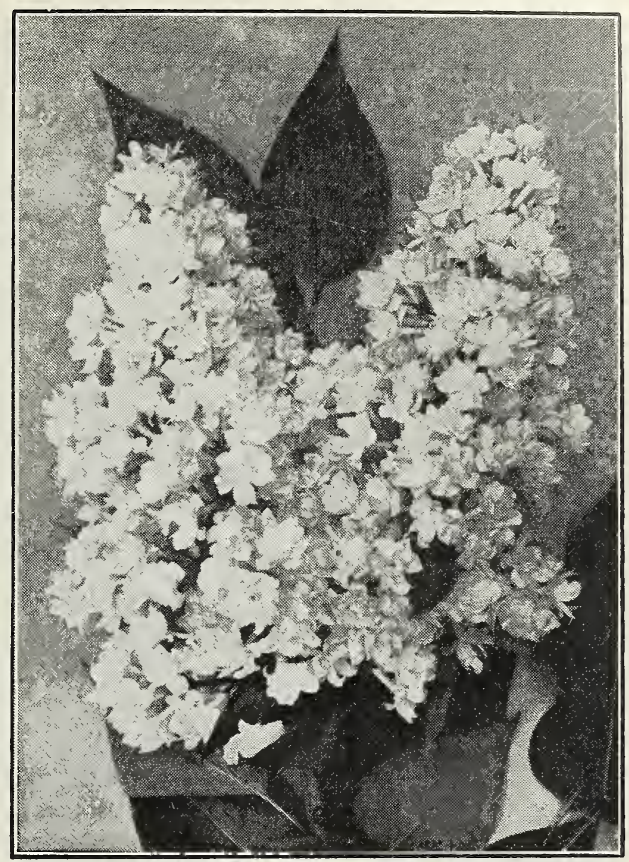

White Double Lilac

Van Houtte.-Without doubt the finest variety in the collection. At the flowering season in May and early June the plant is covered with a mass of large, white flowers, presenting a beautiful appearance. Very hardy. One of the finest shrubs.

\section{SUMAC-Rhus.}

Cut-leaved Sumach.-A very striking plant, of moderate size, with deeply cut leaves, resembling fern leaves; dark green above and glaucous below, and turning to a rich red in autumn.

Cut-Leaved Staghorn Sumach.-A picturesque form, with handsome leaves and deeply cut leaflets.

Staghorn Sumach.-A large shrub or tree, brilliant foliage and scarlet fruit in auturn.

\section{SYRINGA OR MOCK ORANGE-Philadelphus.}

The Syringa is of vigorous habit, very hardy, with large, handsome foliage, and white flowers, produced in the greatest profusion at the blossoming season. Most of the varieties, except those of dwarf habit, form large sized shrubs. They can be kept smaller by pruning. The dwarf sorts are such pretty, compact plants as to be very useful where small shrubs are desired.

Double-flowered Syringa.-A variety with partially double, very fragrant flowers.

Syringa, Purpurea Maculata.-Growth the same as Mock Orange; flowers white with purple center. The finest of all the Syringas. 


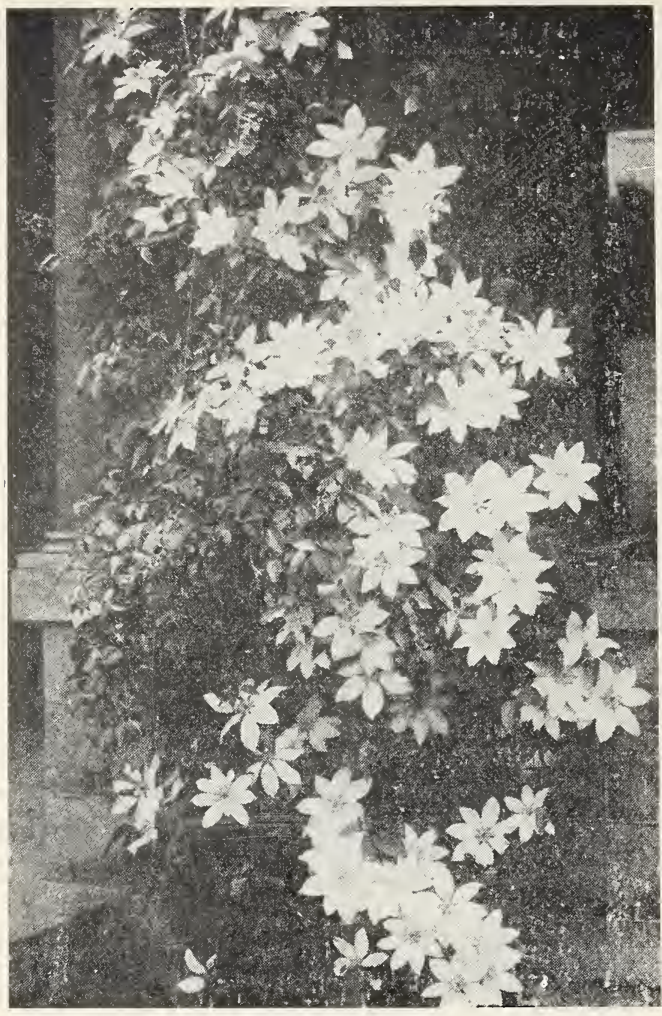

Clematis-Henryii

Golden-leaved Syringa.-This is a very pretty, medium size plant, with golden yellow foliage. It keeps its color the entire season; valuable for striking contrasts with purple. leaved shrubs.
Variegated.-A magnificent new variety with beautiful foliage, somewhat similar to the Variegated Althaea; very rare as yet. A great acquisition.

\section{TAMARIX.}

This is a hardy shrub, with small leaves. similar to the Juniper; the flower is small and delicate and borne in spikes; does well by the staside, where other plants cannot live.

\section{WEIGELA-Diervilla.}

Very desirable, hardy, easily grown land great bloomers. As these shrubs grow older they gradually spread and droop; flower in June and July; in borders and groups of trees they are very effective; bloom after lilacs in June. The following are the most desirable varieties:

Amabilis.-Of robust habit, large foliage and pink flowers, blooms freely in the autumn; distinct and beautiful.

Candida.-Of vigorous habit, an erect grower; flowers pure white and produced in great profusion in June, and the plants continue to blcom throughout the sumnier, even until autimm.

Floribunda.-(Crimson Weigela)-The flowers are dark crimson, with white stamens projecting from them, reminding one somewhat of Fuschia flowers. It blooms in the spring.

Rosea.-An elegant shrub, with fine rosecolored flowers; of erect, compact growth; blossoms in June.

Variegated-leaved.-Of dwarf habit, and possessing clearly defined silvery variegated leaves; flowers nearly white. It stands the sun well, and is one of the best dwarf variegated-leaved shrubs.

Weigela, Eva Rathke.-A charming new Weigela; flowers, a bright crimson. Very choice.

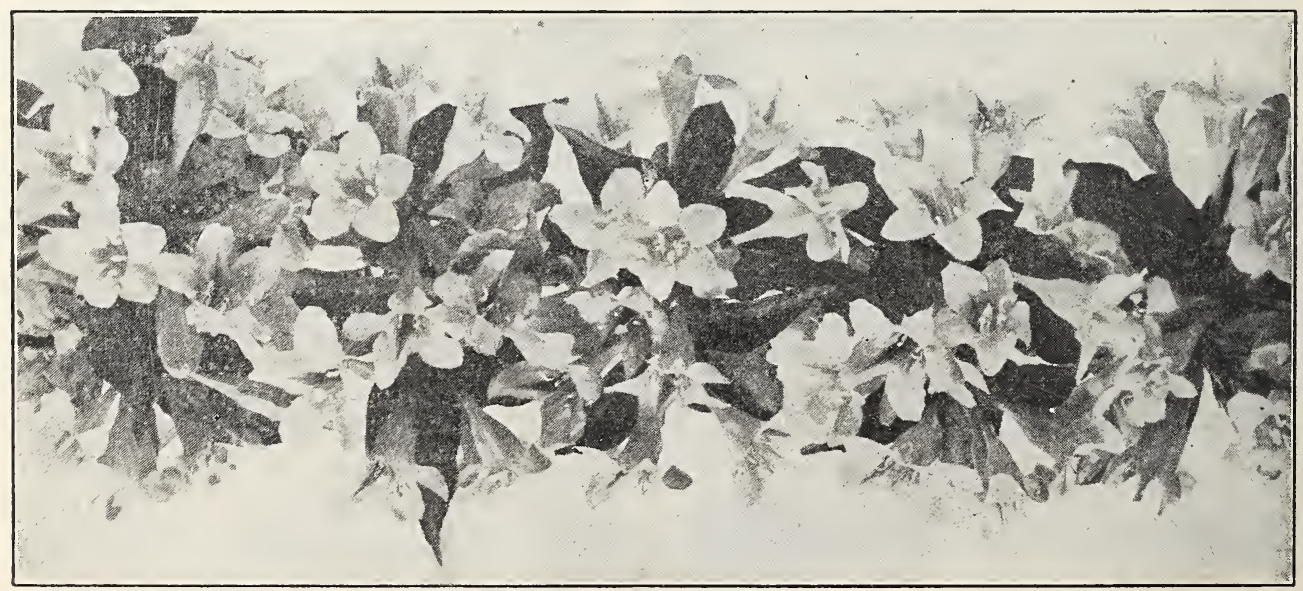




\section{CLIMBING AND TRAILING SHRUBS}

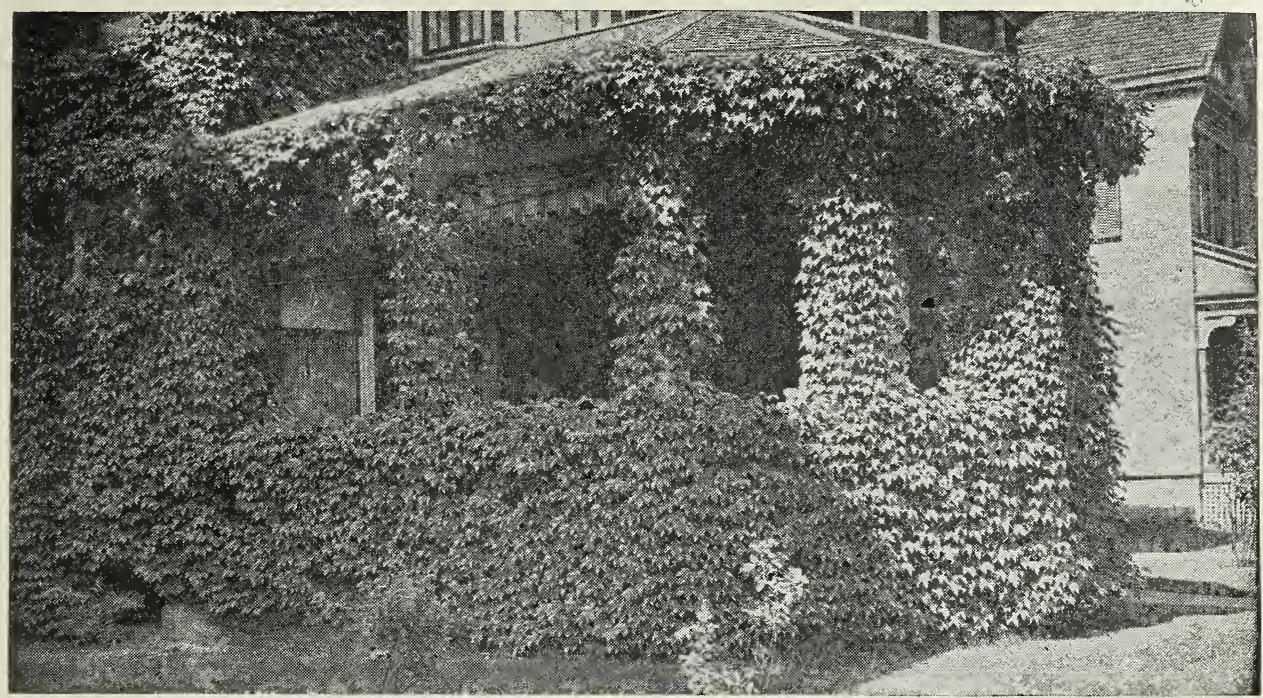

BOSTON IVY

\section{AMPELOPSIS.}

Ampelopsis, Engelmanni.-Similar to Quinquefolia. A good climber, growing from six to ten feet in a season.

American Ivy, or Virginia Creeper.-Has beautiful digitate leaves that become rich crimson in autumn. A very rapid grower. Like the ivy, it throws out roots at the joints, by which it fastens itself to anything it touches.

Veitchii, or Japan Ivy.-(Boston Ivy)Le:l res smaller than those of the American, and overlap one another, forming a dense sheet of green. The plant is a little tender while young. and requires protection the first winter; but once established, there is no further risk. It grows rapidly and clings to the wall or fence with the tenacity of ivy; the foliage is very handsome in summer, and changes to crimson scarlet in autumn. For covering walls, stumps or trees, rockeries, etc., no plant is so useful. For the ornamentation of brick and stone structures, it can be specially recommended.

\section{BIRTHWORT-Aristolochia.}

Dutchman's Pipe.-A native species, of climbing habit and a rapid grower, with beautiful light green foliage ten to twelve inches in diameter and pipe shaped with yellowish brown flowers.

\section{BIGNONIA, OR TRUMPET FLOWER.}

A vigorous and hardy climber, with clusters of scarlet trumpet-shaped flowers in August.

\section{THE EVERGREEN BITTERSWEET-}

Climbing Euonymus Radicans Vegetus.

Beautiful 365 Days of the Year.

Particularly adapted to cover garden walls, old stumps or embankments with any exposure, but the fruiting is best when the plants receive the warm sun; the plants are strong, robust climbers and in fall and winter bear a profusion of bright red berries. The vine is covered the whole year with green foliage, and absolutely holds the color even in hottest summer or the coldest winter. The vines show many clusters of bright red berries that carry them through the winter months.

Alexandria.-This is one of the continuous blooming sorts of real merit. The flowers are large and of a pale reddish-violet color. Desirable. July to October.

Coccinea.-Very hardy; bears thick, bellshaped flowers, bright red coral; blooms very profusely during June and until frost. One of the best of the older sorts. Valuable for foliage, being a peculiar green and elcgantly cut and variegated.

Crispa.-Very hardy and a free bloomer; flowers blue, with center of petals an opaque white; very fragrant; useful for festooning.

Dutchess of Edinburgh.-A double, pure white variety which is very popular; requires some protection; deliciously scented.

Henryi.-One of the best perpetual Hybrids; of robust habit and a very free bloomer. Flowers white, large and very showy. 


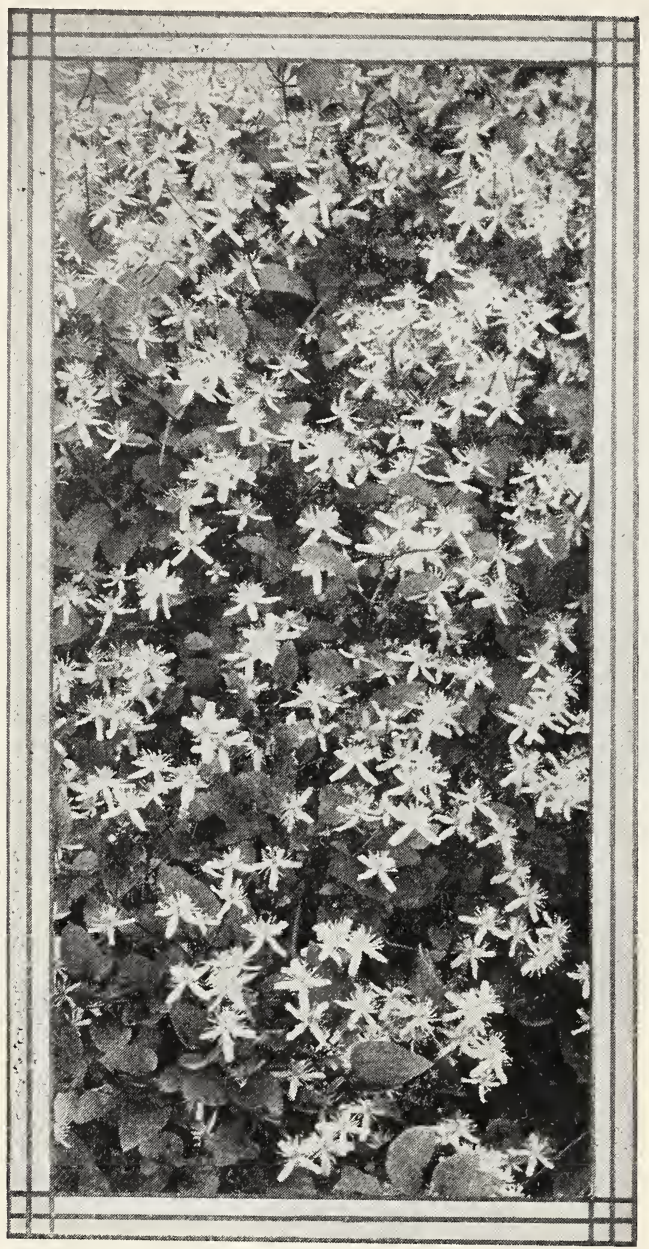

Jackamnni Clematis

Jackmanni.-One of the most popular varieties, a free grower and abundant and suc. cessful bloomer. producing flowers until frozen up. Color an intense violet purple, remarkable for its velvety richness.

John Gould Veitchi.-Flowers are very handsome, distinct, large, double and of a light blue or lavender color; a very choice double variety. June and July.

Mme. Edward Andre.-A. vivid crimson flower, large size and borne as freely as the Jackmanni. The habit is vigorous and the plant is popular on account of its exceptional brilliancy and persistency as a bloomer.

Paniculata.-A sweet-scented Japan Clematis. This variety is now quite generally planted throughout the country. It is a vine of very rapid growth, quickly covering trellis and arbors with handsome, clean, glossy green foliage. The flowers are of medium size, pure white, borne in immense sheets and of a most delicious and penetrating fragrance.

Ramona.-This magnificent new Clematis is an American seedling, and consequently extremely hardy. The Ramona is a strong, rampant grower, fully three times as strong as the Jackmanni, of ten growing ten or twelve feet the first season. It is a perpetual bloomer, giving an abundance of flowers through the season. In color it is a very deep sky-blue, distinct from any other kind, and very attractive.

\section{HONEYSUCKLE-Lonicera.}

Monthly Fragrant, or Dutch Honeysuckle.Blooms all summer. Red and yellow, very fragrant flowers.

Hall's Japan Honeysuckle.-A strong, vigoruus, almost evergreen sort, with pure white flowers, changing to yellow. Very fragrant, and covered with flowers from July to December; holds its leaves till January. The best bloomer of all.

Scarlet Trumpet Honeysuckle.-A strong, rapid grower, and produces scarlet inodorous flowers.

\section{MATRIMONY VINE-Lycium.}

Chinese.-A superb variety, which has been a favorite for many years. It is a most vigorous, hardy climber in any position. It continues flowering, and new berries are forming from late spring until frost. The berries remain on the vine until late into the winter. Beautiful and easy of culture.

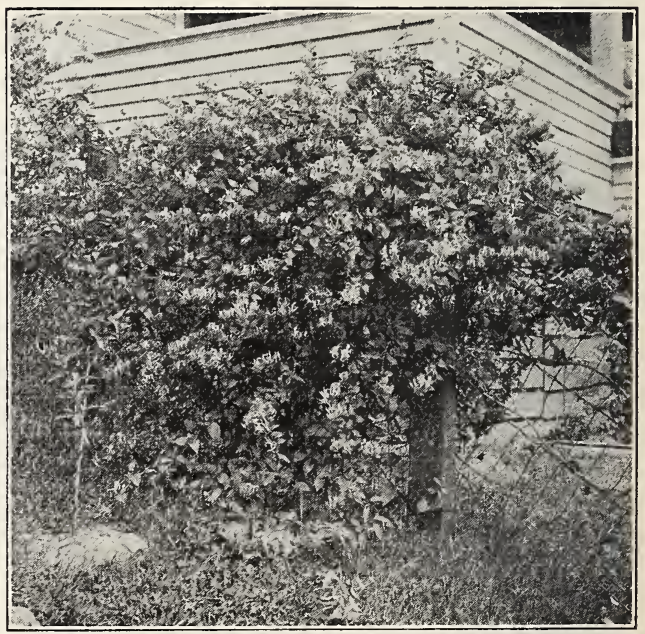

Scarlet Trumpet Honeysuckle 


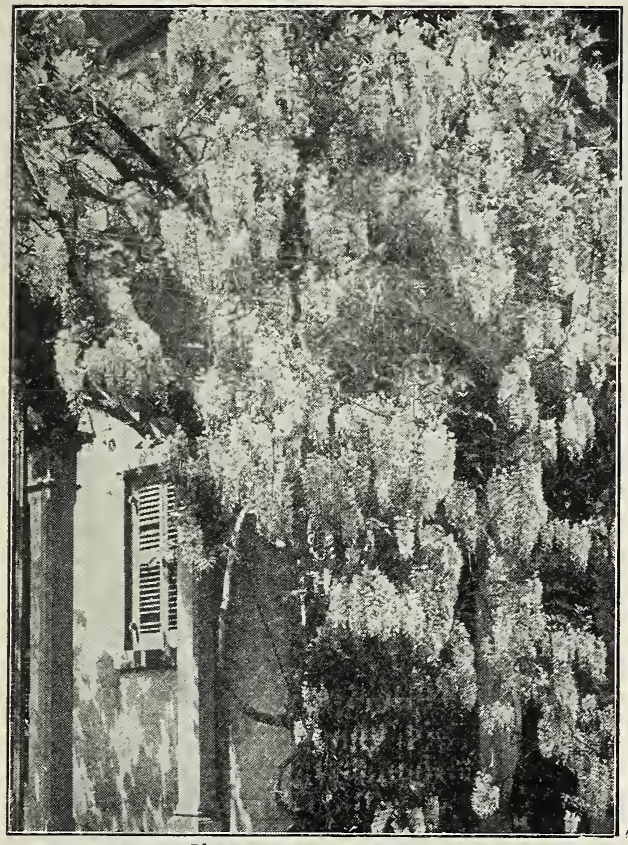

Chinese Purple Wisteria

\section{WISTERIA.}

Chinese Purple Wisteria.-One of the most elegant and rapid growing of all climbing plants; attains an immense size, growing at the rate of 15 to 20 feet in a season. Has long, pendulous clusters of pale blue flowers in May and June and in autumn.

Chinese White Wisteria.-Pure White flowers; beautiful.

\section{EVERGREEN SHRUBS}

Beautify your home by planting shrubs, vines and flowers. The property increases in value and in case you desire to sell you can realize a large percentage on the investment.

\section{Box-Buxus.}

Dwarf.-(Nana)-The well-known sort used for edging.

Tree Box.-Sempervirens)-A shrub of the largest size, succeeding well in the shade.

\section{DAPHNE.}

Cneorum.-A beautiful evergreen shrub with fragrant pink flowers. Blossoms June and Oct.

\section{MAHONIA.}

Holly-leaved, - (Aquifolium) - A beautiful Holly-like shrub, with showy, golden yellow flowers and purplish leaves. Very ornamental.

\section{MOUNTAIN LAUREL-Kalmia.}

Latifolia.-Broad, glossy-green, shining foliage, flowers in large and showy clusters of elegant shape, and most beautifully colored. Few broad-leaved evergreens are as beautiful in foliage, and none can excel the beauty and delicate form of its flowers.

\section{RHODODENDRON-Rosebay.}

This, wherever grown, is universally acknowledged to be the most showy, magnificent hardy evergreen shrub that grows. It should be planted in well prepared soil of leaf mould, or leaf mould and muck and peat mixed, and in partial shade. The broad thick evergreen foliage, with its glossy richness, would alone entitle it to a place foremost in the rank of evergreen shrubs; but when in June this luxuriant mass of evergreen foliage is almost hidden by the magnificent array of beautiful flowers in clusters and each cluster large enough for a lady's bouquet, it gives it a pre-eminence that our pen would fail to portray. Planted singly, in the flower garden or upon the lawn, they are objects of interest, but their greatest beauty, as in many other plants, can only be fully developed by artistically massing them in beds upon the lawn, when the different colors can be made to blend or contrast at will.

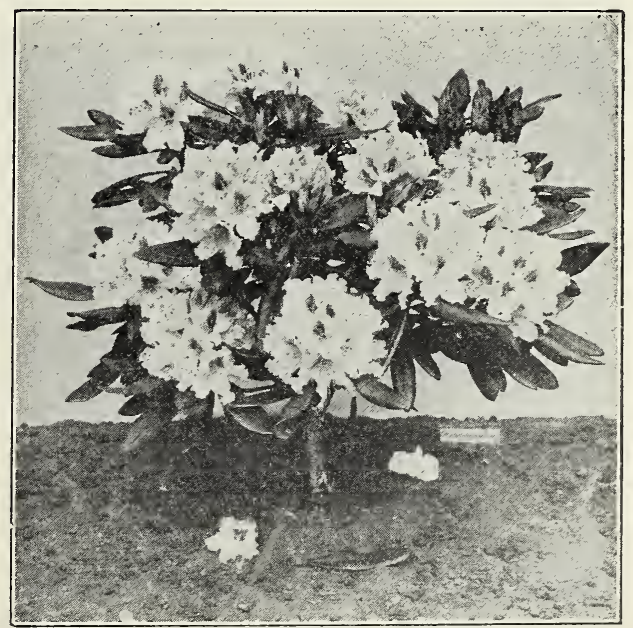

Rhododendron 


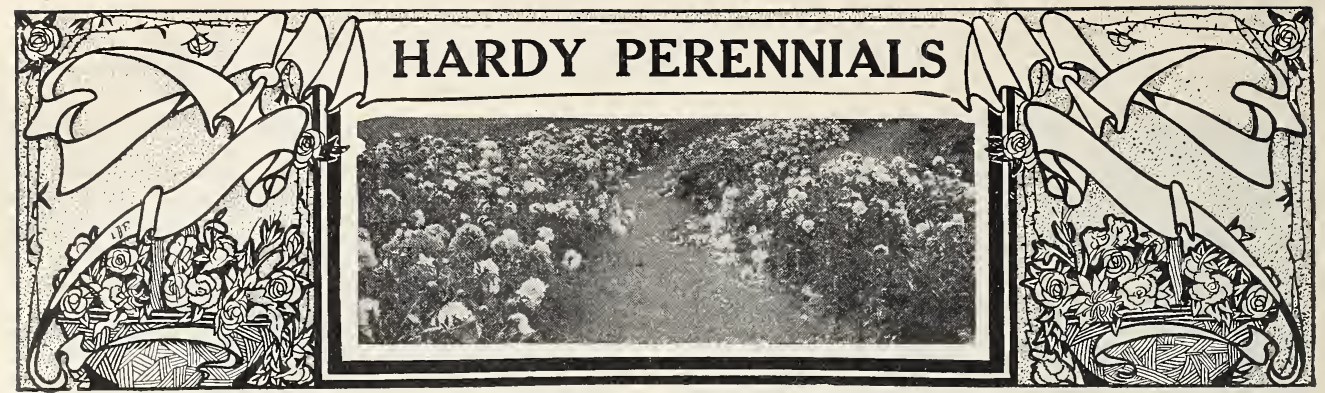

\section{PAEONIAS}

The r'aromia is a noble flower and is being planted very extensively of late years. It was

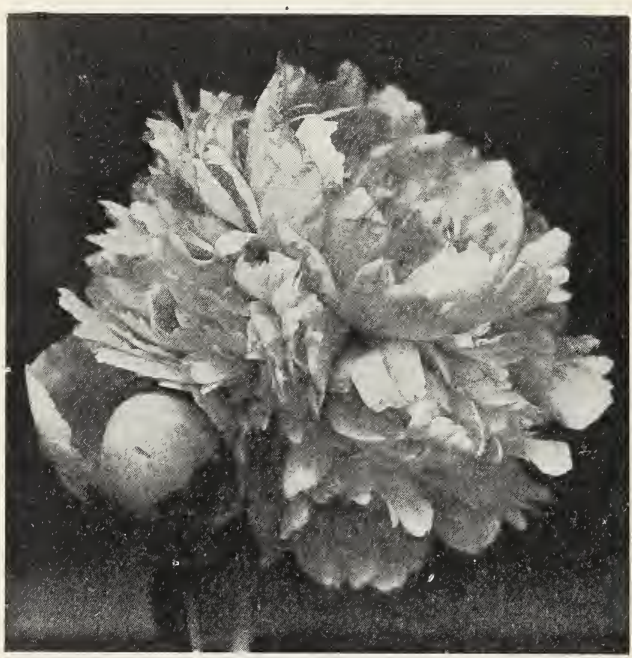

Festiva Maxima

always popular. The new and choice varieties introduced of late years almost rival the rose in beauty and fragrance.

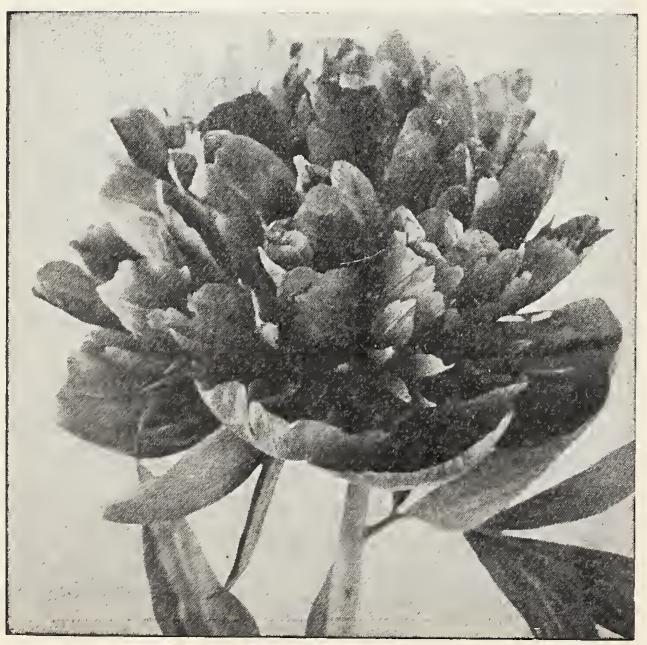

Marechal Vaillant
The Paeonia can be planted either in the fall or spring. If planted in the fall they flower earlier in the season, on account of being well established. They require no protection, come up every season, can be left in the ground indefinitely, and will thrive in any soil. They prefer a sunny position and respond promptly to good treatment.

Festiva Maxima (Miellez, 1851).-For enor mous size combined with wondrous beauty ths variety has stood unsurpassed for over sixh years. Pure paper white flaked with purplisy carmine on some of the center petals. Early very fragrant, rose type bloom. Of vigorous growth, with very long heavy stems.

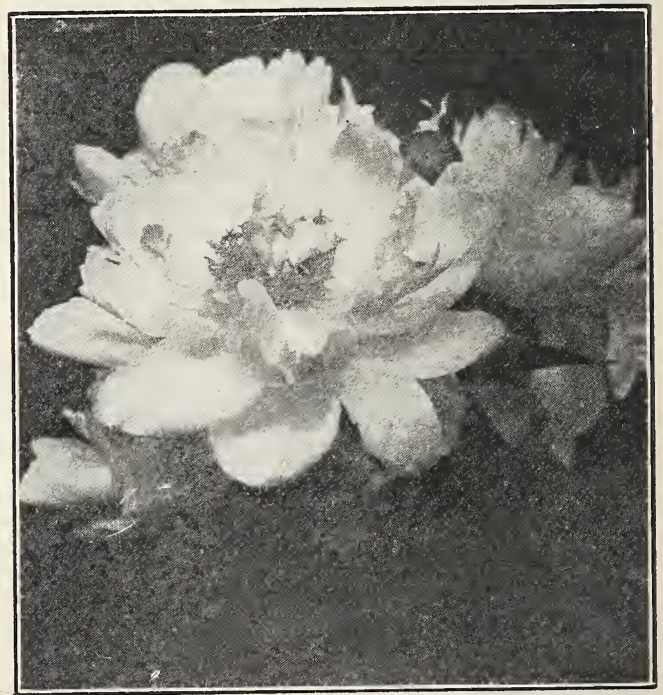

Mons. Dupont

Marechal Vaillant (Calot, 1867)-Blood red one of the largest, of fine form; fragrant; a good keeper; strong, rather spreading growth; a very showy flower. Rose type; very late.

Mons. Dupont (Calot, 1872).-Large, fragrant cup-shaped bloom of semi-rose type; ivory white, outer petals streaked and inner splashed with carmine; growth strong, tall; blooms freely in clusters. Late midseason. 


\section{CLASS I.-PAEONIA MOUTAN TREE PAEONIES.}

Moutan.-The parent species is a native of China. The varieties are handsome flowering shrubs, attaining from six to eight feet in height, in about ten years with proper care. The flowers are remarkably striking, of gorgeous colors, very numerous and enormous in size. often measuring from six to nine inches across, and appearing in May.

Alba Pleno.-Double white, shaded with purple at the center.

Banksii.-(Chinese Double Blush Paeony)Very large, fragrant flowers; rosy blush with purple center. One of the finest.

\section{CLASS II.-CHINESE HERBACEOUS PAEONIES.}

These are beautiful, showy, and easily cultivated plants, blooming from the beginning of May till the end of July. They should have a place in every garden. A selection will give a continuous bloom for three months. We offer the best sorts, varying from pure white, pink rose, dark red, purple and deep crimson.

Fringe leaved Paeonies.-(Paeony Tenuifolia, fl. pl.) - Foliage a bright, lively green, in long thread-like filaments, giving it the appearance of fringe. Scarlet crimson; a choice variety; perfectly hardy.

\section{ANCHUSA.}

Dropmore.-This is the most important hardy border plant introduced in many years. The best blue flowered plant we have. It is hardy, growing to a height of $31 / 2$ feet, making a bushy plant which is literally covered with pure blue flowers one inch in diameter, and is then a paragon of beauty.

\section{ANEMONE-Wind Flower.}

Japonica.-A d' 'inct and beautiful species; flowers $2 \frac{1}{2}$ inches in diameter; bright purplish rose, with golden yellow centers, borne in great profusion from september to November. Height 21/2 feet; habit neat and compact; very desirable and effective as a pot plant, and in lines or masses, in beds or mixed borders.

Queen Charlotte.-A new variety producing double rose colored flowers in great profusion in the autumn. Very valuable.

Whirlwind.-A variety producing double white flowers in great profusion in the autumn. One of the finest fall-flowering perennials.

White.-A distinct and beautiful variety of the Japonica; flowers $21 / 2$ inches in diameter; pure white, center golden yellow, borne in great profusion from September to November; effective as a pot plant, and in lines or masses, in beds or mixed borders.

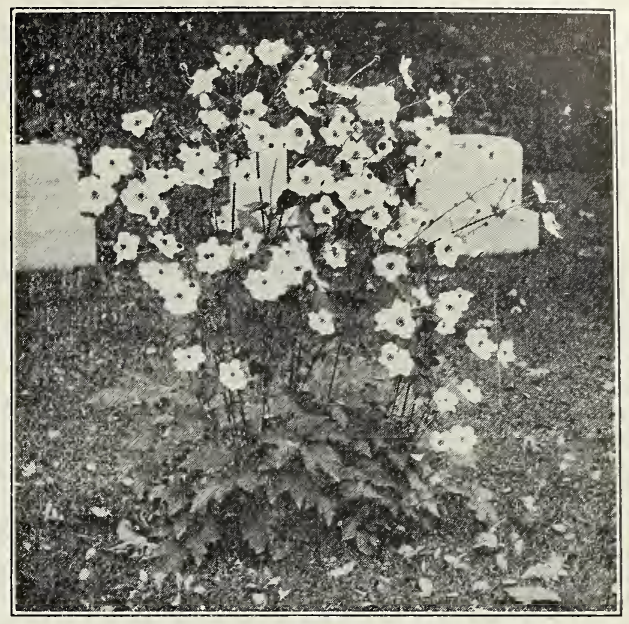

Anemone

\section{AQUILEGIA-Columbine.}

Caerulea.-(Rocky Mountain Columbine)Flowers large, blue and white, with long spurs. June to September.

\section{BLUE BIRD FLOWER}

Blue Bird Flower.-(veronica longifolia subsessilis) is destined to create as much furor in the floral world as did the Golden Glow. Aside from Larkspur, some varieties of Altheas and Perennials, there are few true Blue Flowered Plants. The Blue Bird Flower is the handsomest blue flowered plant we know of, growing to a height of two feet and completely studded with its spikes of blue flowers, that at a distance resemble blue birds perched in the foliage. Its flowers are fine for cutting. It is perfectly hardy and increases in strength and beauty each succeeding year. It makes the ideal and very best blue flowered hardy border plant obtainable.

\section{C.SRYSANTHEMUMS}

The small flowered, hardy Chrysanthemum is the only variety we offer. We can supply them in pink, red, rose, white and yellow.

\section{COREOPSIS.}

Lanceolata.-One of the best perennials in cultivotion with large, lemon yellow flowers on long stems; all summer. Two to three feet.

Grandiflora.-A free flowering, desirable species, with rich golden yellow flowers in profusion; early summer until fall; eighteen inches.

\section{DELPHINIUM-Larkspur.}

A remarkably showy class of tall growing plants, producing magnificent spikes of blue flowers in summer. We know of no plants which will afford greater satisfaction than these. 


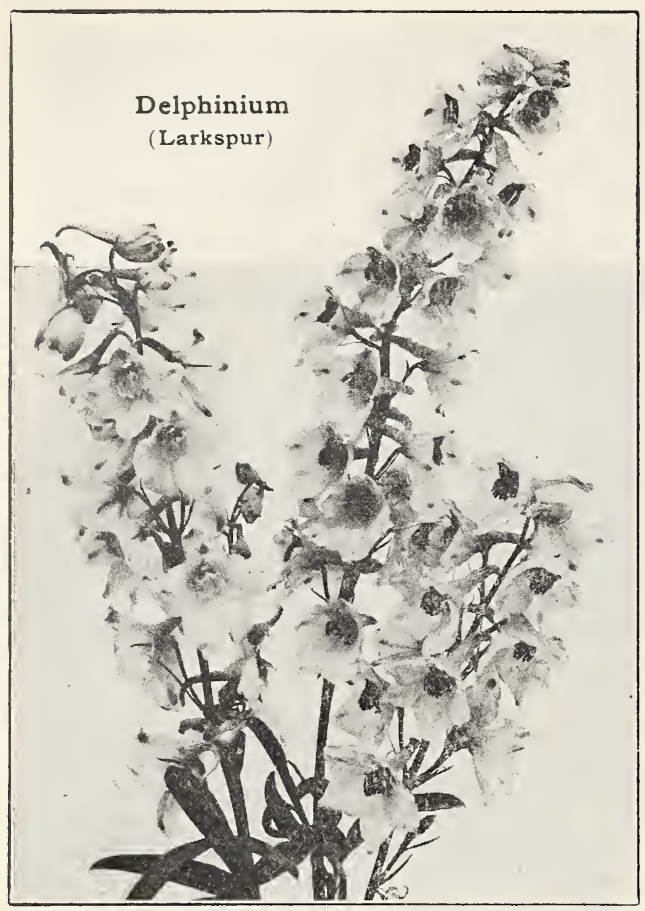

\section{DIANTHUS.}

Barbatus. - (Sweet William) - Flowers in various colors, in flat heads. An old favorite.

Dielytra. - (Bleeding Heart) - Rosy, heartshaped flowers hanging in great profusion from a graceful curved stem. May and June.

\section{DIGITALIS-Fox Glove.}

Flowers purple, yellowish or white, in long terminal racemes; two to three feet. June to August.

\section{EULALIA.}

These beautiful hardy grasses are deserving of the highest commendation. For the garden they are invaluable, being very showy and ornamental and of easy cultivation. They should be in every collection.

Gracillima.-A beautiful ornamental grass with narrow graceful foliage. Very valuable; four feet.

Japonica.-A vigorous grower with large plumes; four feet.

Variegata.-Handsomely variegated leaves; four feet.

Zebrina. - (Zebra-striped Dulalia) - One of the most beautiful of ornamental grasses; foliage marked crosswise with bands of white and green.

FUNKIA-Plantain Lily.

Undulata Var. - (Day Lily) - One of the easiest plants to manage, doing well either in shady or very sunny places. Foliage variegated green and white, purple lily-like flowers.
GAILLARDIA-Blanket Flower.

Grandiflora.-One of the most effective and showiest hardy flowering plants, with gorgeous flowers of bright yellow and orange, with deep crimson centers; blooming from early summer until late autumn.

\section{HIBISCUS-Rose Mallow.}

The Hibiscus are valuable border plants, having handsome broad leaves and large showy blossoms.

Albus.-(Crimson Eye)-Large, showy, white flowers, crimson eye, blooming in August. Four to five feet.

\section{HOLLYHOCK.}

A fine collection of colors.

IRIS-Fleur de Lis.

Germanica.-(German Iris) - These are among the most desirable early spring flowering plants. Flowers are large and of the most exquisite coloring. Every garden and border should have a liberal planting of these beautiful plants, of which we have the following colors: Blue, lavender, maroon, purple, white and yellow.

Kaempferi. - (Japan iris) - Flowers differ from the German Iris, in being broad and flat. They exhibit a wonderful variety of colors and shades and appear later than the others. They rank among the most desirable of hardy plants; succeed best in a moist soil; three to four feet. July.

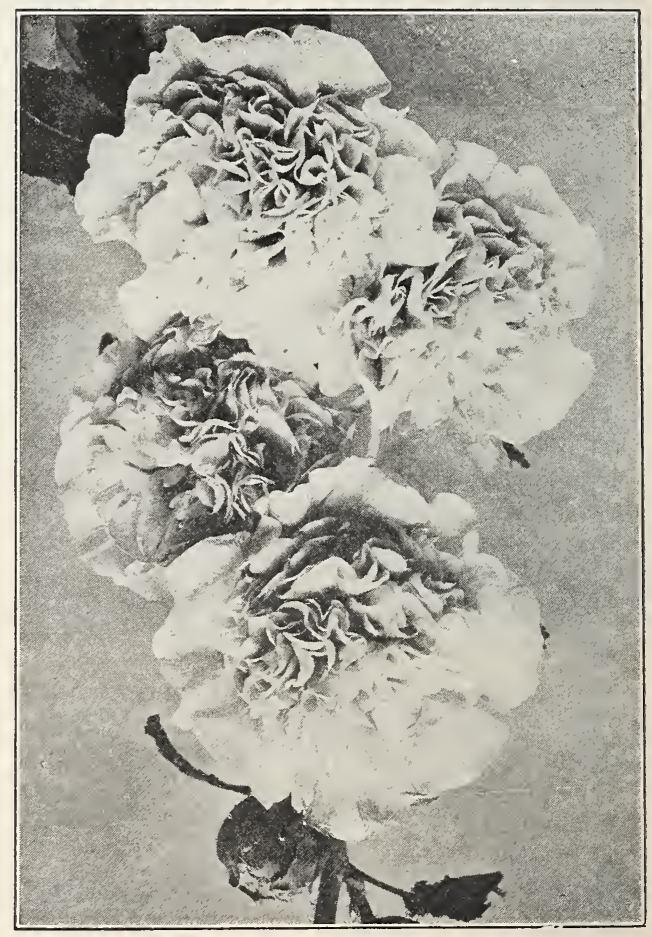

Double Hollyhocks 


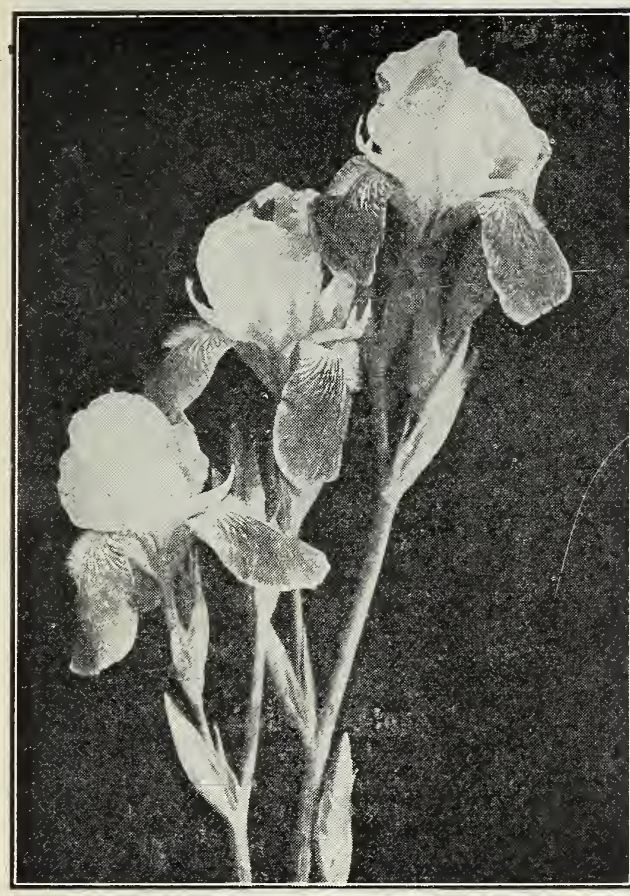

German Iris

PAPAVER-Poppy.

Showy perennials with large flowers of rich and striking colors.

Orientale.-Deep scarlet; large; very showy; eighteen inches. June.

\section{PHLOX}

One of the finest autumn flowers. It is of vigorous habit, easy culture, and produces in great profusion during a long season; flowers of fine form and substance, and of bright and varied colors. As regards their culture it may be briefly stated that they succeed in any good garden soil, but they are greatly improved by being liberally manured, and an occasional supply of liquid manure during the growing season will greatly increase the size of their trusses. When in flower they should be watered freely every evening. The Phlox usually flowers in July and August. The best time to plant them is in the autumn. fine.

Aguillon.-Deep rose, carmine center;

Amabalis. - (Carand Ache) - Deep cherry.

Coquelicot.-Scarlet crimson; the best red Phlox.

Eclaireaur.-Bright carmine rose ; large flowers.

Embrazement.-Coppery red, purple eye.

Feude Bengal.-Fiery red, showy and effective.
King of Purple-Deep glowing purple; extra fine.

Lustre.-Large rose. Pink, dark carmine center.

Lothair.-Salmon; crimson eye.

Pantheon.-Flowers large, beautiful; pink, salmon rose; fine.

Purity.-Pure white, large trusses; the best white.

Richard Wallace.-White; rosy center.

William Robinson.-Deep rosy salmon, purple eye.

Eiffel Tower.-A new Chase variety of the clearest salmon with purple eye. There is at present nothing equal to it in Phlox.

\section{RUDBECKIA-Cone-flower.}

Among the most valuable hardy plants, producing showy golden yellow flowers.

Golden Glow, or Summer Chrysanthemum.(Laciniata fl. pl.) -A large, showy plant, attaining in good soil a height of six to eight feet the same season planted. Flowers $3 \frac{1}{2}$ inches in diameter, double, well formed, and of deep golden yellow color, resembling yellow chrysanthemums, and borne on long stems which render them suitable for cutting. Plants bloom profusely from July till September. One of the best novelties in hardy flowering plants.

\section{SHASTA-Daisy.}

Probably no hardy plant has been so highly spoken of in the American Horticultural Press as this production of Luther Burbank, the result of crossing our native field Daisy with some of the choicer European varieties, and bearing beautiful clear glistening white flowers, and bloom continuously from early summer until late fall; perfectly hardy without protection, even in the most exposed location.

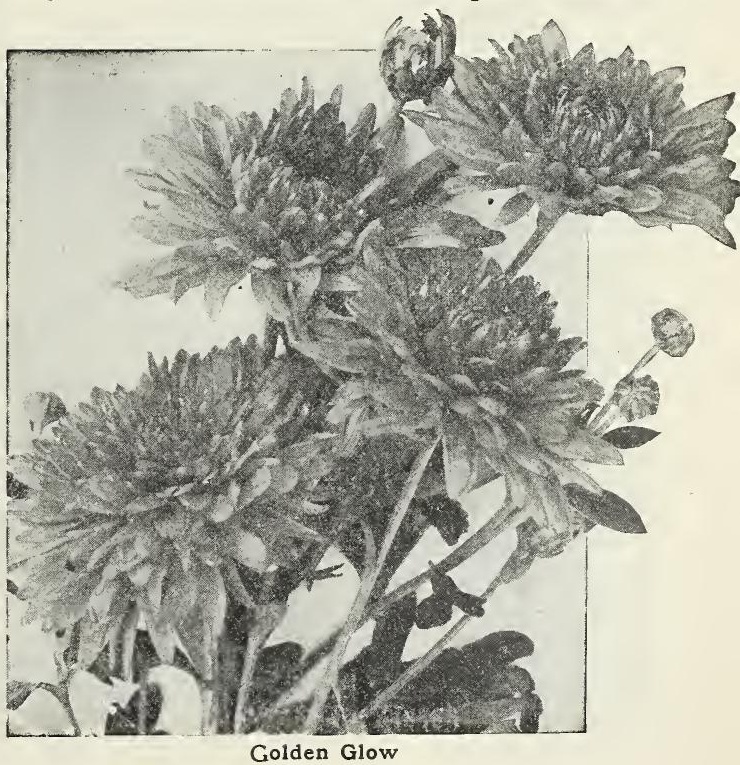




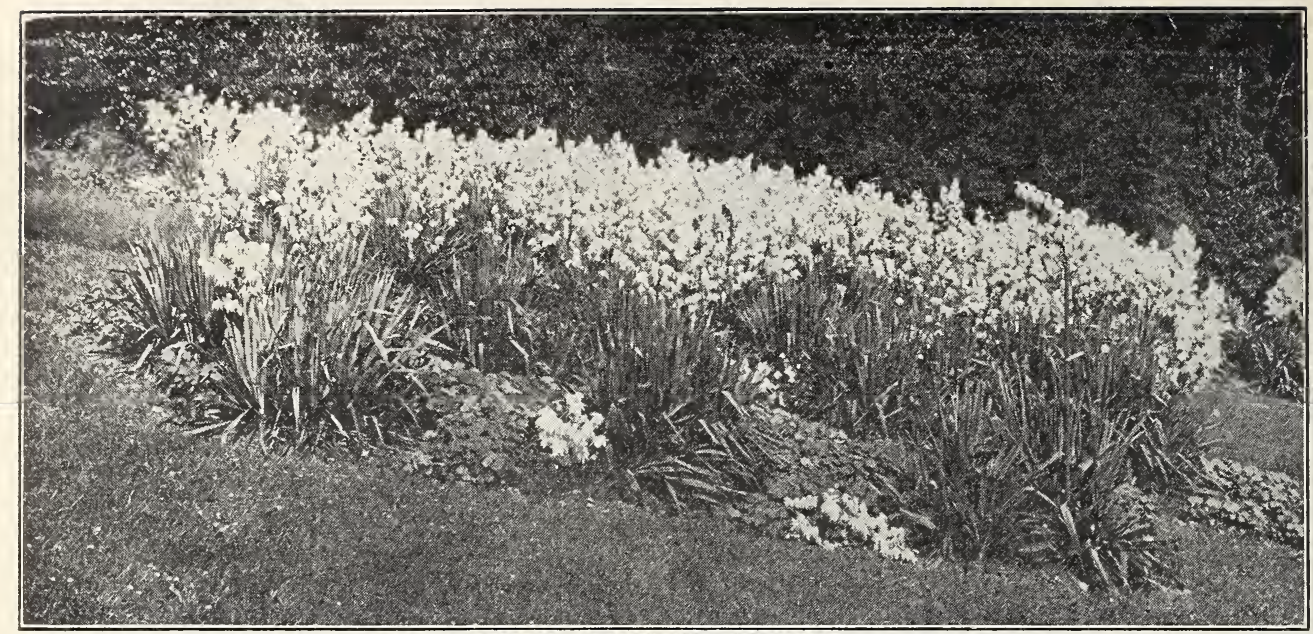

YUCCA-SPANISH BAYONET

TRITOMA-Red Hot Poker.

The-e are well worthy a trial in every garden or border. their brilliant spikes of orange, yellow and scarlet flowers attracting attention wherever seen. Grand plant for massing, flowering from July until frost.

Pfitzerii.-- ( $\mathrm{Th}$ e Ever-blooming Fla me Flower)-The freest flowering variety in cultivation, with spikes from $:$ to 4 feet high and heads of bloom over 12 inches long. of a rich orange scarlet; needs protectionin winter.

YUCCA-Spanish Bayonet.

Ilas a fine appearance; the stem is two feet above the ground, covered with large, bellshaped flowers on laterals, forming a perfect pyramid; valuable for rockwork.

Filamentosa. - (Adam's Needle) - Threadleaved creamy white; three to four feet. July.

\section{Bulbs and Tuberous Rooted Plants}

\section{BEGONIA-Tuberous-rooted.}

Start early in the house and set out when ground is warm; they like rich, moist ground which should be shaded or mulched to prevent drying up.

\section{CANNA. (Spring Planting.)}

Stately and highly ornamental plants, for both flowers and foliage. They attain a height of 2 to 5 feet, and may be grown single or in masses. Leaves green or brownish red; flow. ers scarlet, crimson, yellow, cream, etc., variously marked.

\section{CROCUS. (Fall Planting.)}

An universal favorite and one of the earliest garden ornaments; should be planted about 2 inches deep. Colors, blue, white, yellow and striped.

\section{DAHLIAS. (Spring Planting.)}

There is nothing that, with the same amount of money invested, will give more show of flowers than Dahlias. We offer dry bulbs or tubers.

\section{GLADIOLUS. (Spring Planting.)}

The Gladiolus is the most attractive of all the summer flowering bulbs, and deserves a place in every garden, as it is sure to flower and do well with very little care. Set the bulbs from 6 to 9 inches apart, and about 4 inches deep. Plant from middle of March to first of June.

\section{HYACINTHS. (Fall Planting.)}

The most beautiful and fragrant of early spring flowering bulbs, much used for winter forcing. Pink, Red, Purple, Violet, White.

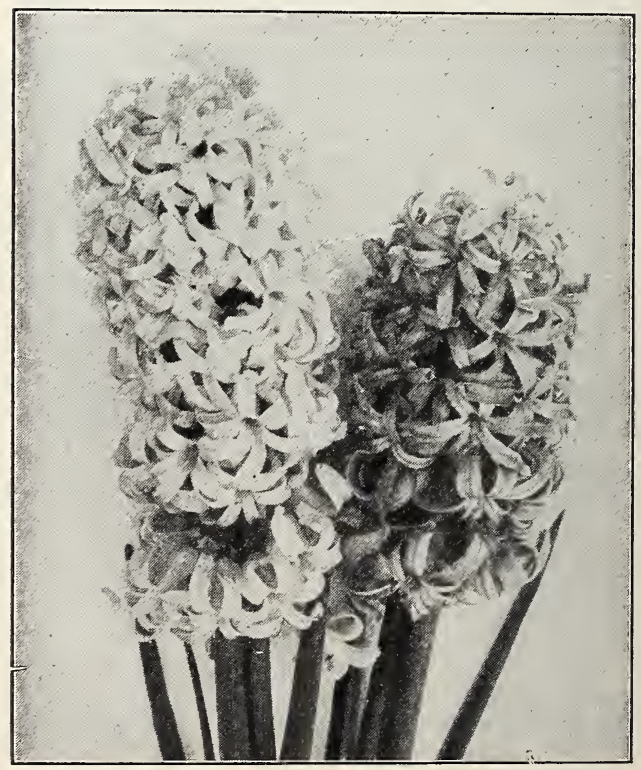

White and Purple Hyacinths 


\section{BEST HARDY LILIES. (Fall Planting.)}

No class of plants capable of being cultivated out of doors possesses so many charms; rich and varied in color, stately and handsome in habit, profuse in variety, and of delicious fragrance. They thrive best in dry, rich soil, where water will not stand in winter. After planting they require very little care, and should not be disturbed for several years. Es. tablished plants bloom more freely than if taken up annually.

Auratum.-(Gold Banded Lily of Japan)Flowers very large, of a delicate ivory white color, thickly dotted with rich chocolate crimson spots, with a bright golden band through the center of each petal. The finest of all lilies.

Candidum.-The old-fashioned pure white garden lily. One of the hardiest.

Harrisii--(The Bermuda Easter Lily) Flowers large, trumpet shaped, pure waxy white, gracefully formed and delightfully fragrant. The ease with which it can be forced into flower in winter has made it wonderfully popular as a winter flower.

Longiflorum.-A well known and beautiful variety, with snow-white trumpet-shaped flowers that are very fragrant, quite hardy and blooms freely in the open ground in June and July.

Pardalinum.-(Leopard Lily)-Scarlet and yellow flowers spotted with purplish brown.

Speciosum Album. - Very fragrant large flowers, pure white with a green running through the center of each petal.

Tiger Lily.-Bright orange scarlet with dark spots; a strong growing, showy variety, and entirely hardy. Succeeds well everywhere.

\section{CALLA LILIES.}

NARCISSUS-Jonquils. (Fall Planting.)

Pretty varieties of the Narcissus, having a very agreeable fragrance; adapted to either pots or ontdoor culture. The bulbs being small, six or eight may be put in a 6 -inch pot.

TUBEROSES. (Spring Planting.)

Tuberoses are among the sweetest and most beautiful flowers in existence. Plant, after the ground gets warm and weather settled, where they are to remain.

\section{TULIPS. (Fall Planting.)}

IVithout these bulbs, for one or two months of beautiful spring weather, our gardens would present a bare appearance. We know nothing that for the money invested will give a more gorgeous show during early spring and there is nothing more easily grown than the Tulip. Should be planted in October or November.

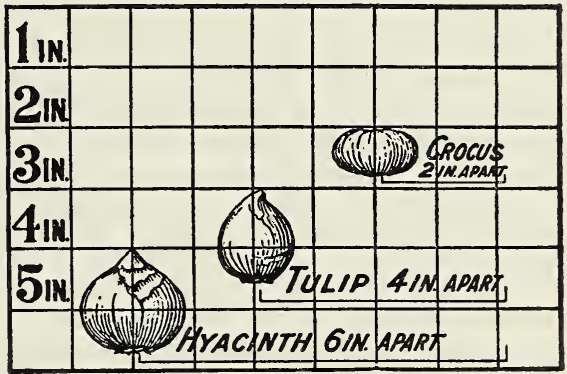

To aid those unfamiliar with the few cultural directions necessary to insure success we have prepared this chart.

Bulbs indoors do not require the deep planting indicated in this diagram, there being no danger from frost to guard against.

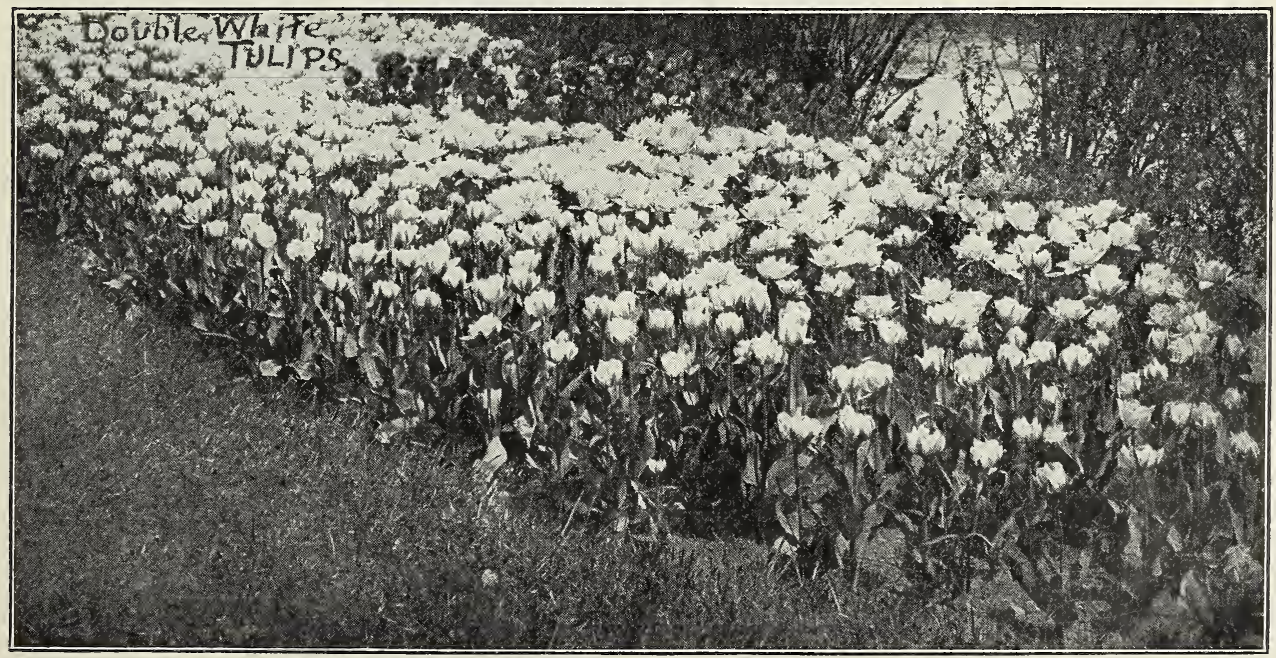

A Bed of Tulips 
BROWN BROTHERS COMPANY, ROCHESTER, N. Y.

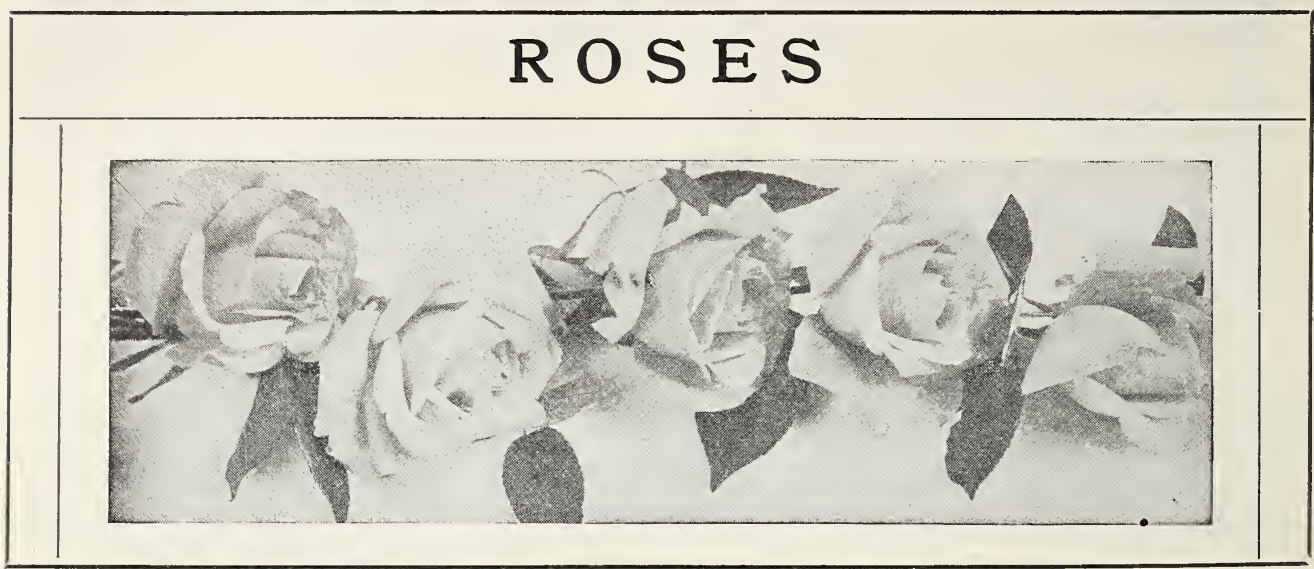

THE varieties of Roses which we describe and illustrate are considered to be the leading kinds. They are the ones which the public buy and have given the best satisfaction. We are on the lookout for best new varieties and spare no pains in obtaining them when satisfied of their real merit.

When properly planted and cared for, they will give perfect satisfaction and will bloom almost immediately after planting. Many varieties need to be well pruned, which insures an abundant growth of new wood on which the blooms appear. Each class of Roses has growth peculiar to that class; hence, customers should not expect that all varieties will grow alike. Some are dwarf by nature; others slender growing; some produce low shape bushes; others are upright and vigorous.

Those who appreciate the beauties of nature, prize Roses above all other flowers. Hot house roses are not as hardy as our field-grown. They are slow to grow and hard to keep alive.

\section{How to Grow Roses}

Soil and Planting.-Most varieties may be planted in the fall as well as in the spring. The ground should be well spaded to a depth of from twelve to twenty inches and liberally fertilized, as also well drained. Roses on their own roots should be planted just as they stood in the nursery. There is usually a dark earth line to go by-set even with this. Budded or grafted roses must be set so that the junction of stock and graft is two inches below the surface of the soil. As soon as the Roses are received, put the roots of the plants in water, allowing them to remain for from six to twelve hours before planting.

Pruning and Cultivation.--Practically all varieties of Roses should be cut back from onethird to one-half when planted and it is also advisable to trim the roots a little. Remove any weak or decayed wood in the top. Varieties which show a vigorous growth may be pruned a little less than others. Many of the Hybrid Perpetual varieties will continue to bloom through the summer, if pruned in July.
Stir the soil frequently about the roots. They require all of the nourishment they can possibly get. Good results are sure to follow.

Protection.-Mulch your Rose bed in autumn and for winter protection, cover with evergreen boughs, if possible. A light mulching during the summer is desirable as it keeps the ground from drying out too rapidly.

Insect Remedies.-If proper attention is given to soil, planting, watering, etc., and a few simple directions heeded. your Roses will never be seriously troubled with any kind of insects or plant diseases. We find that a strong stream of water from a hose applied once a day, will keep the insects from doing any harm. Where this is impossible, we would suggest the following remedies, which will usually keep the Roses free from any insects.

Boil for ten minutes four ounces of quassi chips in a gallon of soft water. Drain off the chips and add four ounces of whale-oil soap, which should be dissolved in it as it cools. Stir well before using. Apply with a clean 


\section{ROSES-Continued}

painter's brush to every leaf and shoot that is infested. After fifteen or twenty minutes, the plants should be washed or syringed with pure water. For mildew, sprinkle lightly with flour of sulphur.

For Rose Bugs.-Dissolve $1 / 4$ pound hard soap in two quarts of boiling water, add 1 pint of kerosene oil, and stir violently for from three to five minutes, until the ingredients are thoroughly mixed; then dilute to twice its bulk with water, apply with a spraying syringe, or sprinkle it on the plants with a whisk broom, and repeat as often as necessary.

Rose Caterpillar appears in May, or about the time the leaves have pushed forth. It can be readily detected, as it glues a leaf or two together to form its shelter. The bushes should be gone over and the glued leaves pinched between the finger and thumb.

Saw Fly, larva and other insects later than the caterpillar may be prevented by an occasional syringing, vigorously applied. When they have appeared a sprinkling of powdered white hellebore over the plants will often destroy and disperse them. The plants should be well moistened before applying the hellebore, so that it will remain.

The Red Spider seldom attacks the plants in the open air, but confines itself to plants under glass. It may be kept off by daily syringing the plants with water. When plants are unce infested with the insect, the fumes of sulphur will alone destroy it. This causes the foliage to drop off, but is the best remedy.

\section{HYBRID PERPETUAL VARIETIES}

This class thrives the best in a rich soil. The pruning should be regulated by the habit of growth, the weak shoots should be closely cut in, those which are vigorous left longer. Most of the varieties are fragrant.

Although they are styled perpetual bloomers, they are not such in reality. However, many of them yield a fair second crop of flowers in the autumn, which is very acceptable. Aside from this, there is no class, take it all in all, so popular and which gives such general satisfaction.

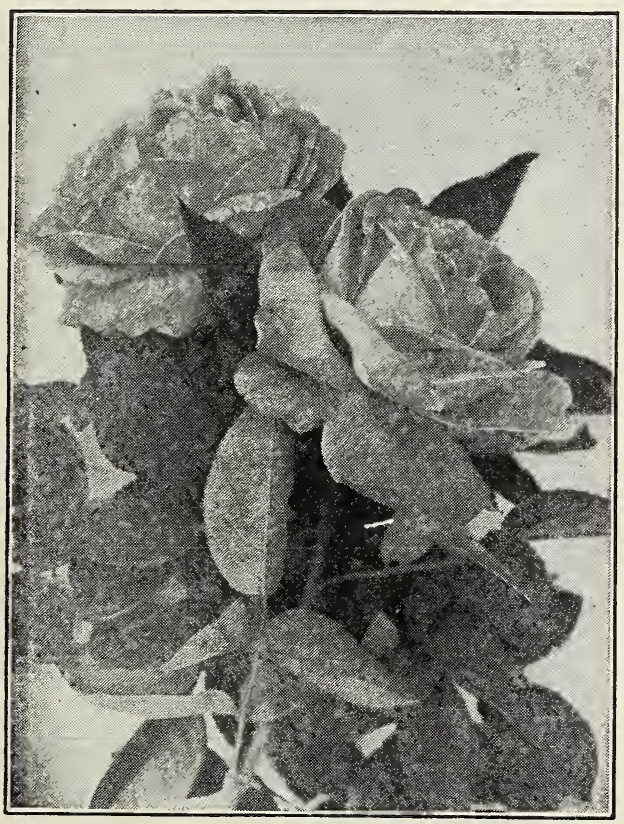

Baron de Bonstetten
Alfred Colomb.-Brilliant carmine crimson; very large, full, and of fine globular form; extremely fragrant, and in every respect a superb sort; foliage large and handsome. One of the most useful of all sorts for general cultivation.

American Beauty.-Large, globular; deep pink, shaded with carmine; delicious odor; especially desirable for forcing. Not a desirable variety for outdoors.

Anne de Diesbach.-Carnnine, a beautiful shade; very large. A superior garden sort; fragrant; one of the hardiest. Valuable for forcing.

Baron de Bonstetten.-Rich Velvety maroon; large, full. A splendid sort.

Black Prince.-Dark velvety crimson, almost black. A good grower and most magnificent rose.

Caroline de Sansal.-Clear delicate flesh color; fine form; a strong grower and one of the best of its color.

Clio.-Flowers large, in clusters, of fine globular form, flesh-color shaded in the center with rosy pink; growth vigorous; handsome foliage. One of the best roses.

Conrad F. Meyer.-This rose has Rugoso blood in its makeup, and is classed as a hybird. A vigorous grower and free bloomer. Flowers large, double, cup shaped. Color deep, bright, vivid, intense pink with a fragrance of June roses.

Coquette des Alps.-White, slightly shaded with carmine; form semi-cupper; wood long jointed; large, handsome flowers. The strong. est grower of the entire class.

Coquette des Blanches.-Pure white, sometimes faintly tinged with pink; flowers of me. dium size, somewhat flat, but full and very pretty; growth more bushy and symmetrical than any of the others; one of the hardiest.

Dinsmore.-Scarlet crimson, large double, very fragrant; free bloomer, one of the finest roses. 


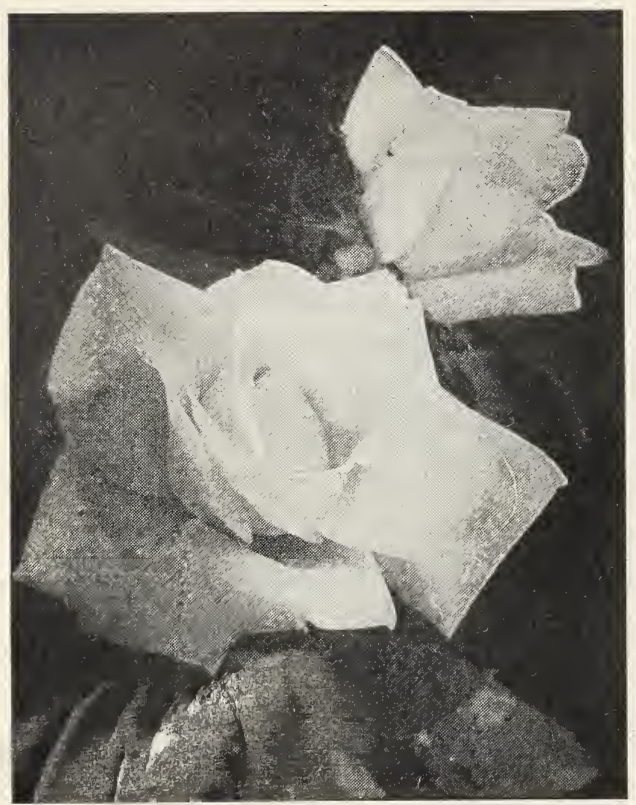

Frau Karl Druschki

Duke of Edinburgh.-Bright crimson, large, double flowers, slightly fragrant. Foliage large and attractive. A free bloomer early in the season.

Earl of Dufferin.-Rich, brilliant, velvety crimson, shaded with dark maroon; large, full, finely formed; delightful fragrance. A vigorous grower.

Fisher Holmes.-One of the choicest of perpetual roses. Bush is vigorous and produces freely of superb blossoms. Color brilliant carmine crimson.

Frau Karl Druschki-(Snow Queen).-Flowers very large, beautiful, pure white. This is the best white Hybrid Perpetual.

General Jacqueminot.-Brilliant crimson; not full, but large and extremely effective; fragrant, and of excellent hardy habit.

General Washington.-Fine crimson; very full and double; a moderate grower; one of the handsomest roses when well grown.

Helen Keller.-Flowers large, of most perfect form and fragrant. Color brilliant rosy cerise. A vigorous grower and very free bloomer. A most distinct and lovely rose.

Her Majesty.-A remarkably strong growing variety, often throwing up shoots six feet in length; the flowers are of unusual size; specimens having been exhibited that were fully six inches across. Color a beautiful, clear satiny pink.
John Hopper.-Bright rose with carmine center; large and full. A profuse bloomer and standard sort.

John Keynes.-A strong grower and as hardy as any of the perpetual family. Flowers very large and fine; brilliant carmine. A splendid rose.

Jubilee.-Flowers very large; color described as intense crimson, maroon red; fragrant, strong and lasting. Plant very vigorous; large, dark green foliage.

Jules Margottin.-Bright cherry red; large and full; free flowering and hardy.

Lady Helen Stewart.-Bright crimson scarlet; large, full, and of perfect form, produced on long, stiff stems, highly perfumed; distinct and fine. A beautiful and valuable variety.

La Reine.-Brilliant, glossy rose, very large, cupped and beautiful; a very hardy useful rose.

Louis Van Houtte.-Crimson, maroon, medium size, sometimes large, full. A tender sort, but very free blooming and altogether the best crimson rose we have. A moderate grower.

Madame Plantier.-Pure white, medium size, iull; flowers produced in great abundance early in the season.

Magna Charta.-Pink, suffused with carmine; full, globular. Foliage and wood light green, with numerous dark spines. A fragrant, excellent rose. Valuable for forcing.

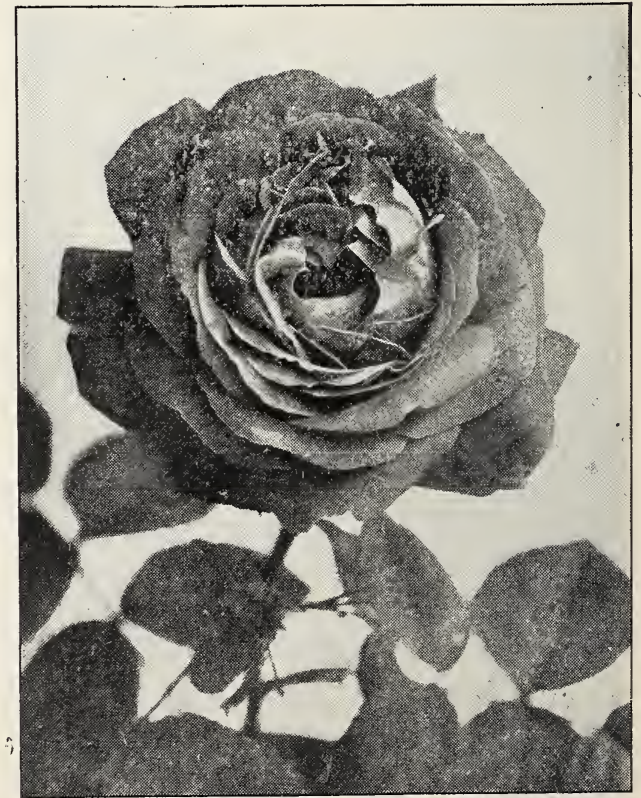

Louis Van Houtte 


\section{ROSES-Continued}

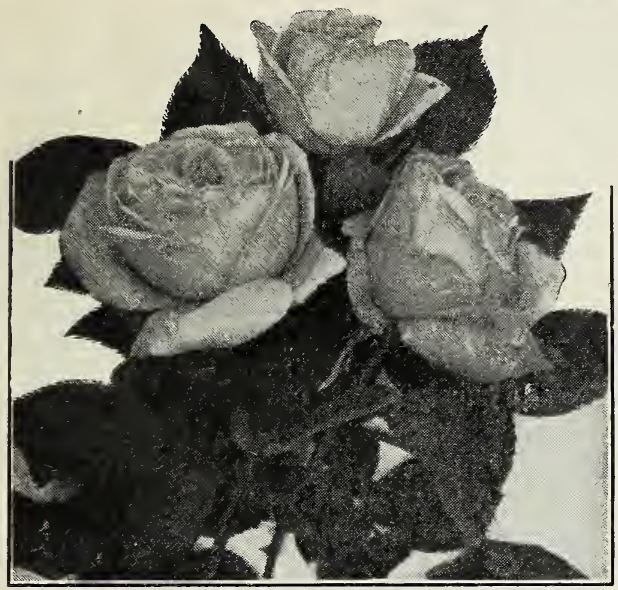

Mrs. John Laing

Madame Gabriel Luizet.-Pink, distinct, very large, cupped-shaped; somewhat fragrant. One of the choicest.

Marchioness of Londonderry.-Flowers of great size, perfectly formed, and carried on stout stems. Color ivory white; petals of great substance, shell shaped and reflexed; free flowering; highly perfumed; growth vigorous and foliage very handsome.

Margaret Dickson.-Of magnificent iorm; white, with pale flesh center; petals very large, shell shaped, and of great substance; fragrant, a fine variety; foliage very large, dark green.

Marchioness of Dufferin.-A new rose which has attained much popularity. It is of enormous size, beautiful rosy pink, suffused with yellow at the base of petals; a very strong rapid grower; considered one of the finest.

Marchioness of Lorne.-An exceedingly rich rose color, shaded in the center with vivid carmine; cup-shaped, sweet and full. Buds usually handsome. Free flowering.

Marshall P. Wilder.-Of vigorous growth, with healthy foliage; flowers large, semi-globular, full, well formed; color cherry carmine, very fragrant. It continues to bloom profusely long after the other Hybrid Perpetuals are out of flower.

Meteor.-As a dark crimson perpetual bloom. ing rose, this ranks as one of the best yet introduced of any class. It is especially valuable for summer and fall, blooming either in the greenhouse or in open ground, and where there is a demand for fine roses in summer this variety will become a great favorite.

Mrs. John Laing.-Soft pink; large and of fine form, produced on strong stems; exceed. ingly fragrant; one of the most valuable varieties for forcing, and flowers continuously in the open ground. Very desirable.

Mrs. R. G. Sherman Crawford.-Color deep rosy pink, outer petals shaded with pale flesh, white at base of petals; flowers large, of perfect imbricated form, and freely produced, flowering from early summer until late in autumn. Growth vigorous.

Paul Neyron.-Deep rose color; good tough ioliage, wood rather smooth; by far the largest variety in cultivation. A free bloomer; very desirable as a garden rose; valuable for forcing.

Pierre Notting.-Deep maroon, illumined with bright crimson; large or very large; globular form, pointed buds; highly scented. A superb dark rose, often at its best in the autumn.

Prince Camille de Rohan.-Deep velvety crimson, the nearest approach to a black rose; large, moderately full. A splendid rose.

Soleil D'Or.-(Golden Sun)-New. Hardy yellow rose; foliage glossy. Moderate in growth and is sure to be popular.

Ulrich Brunner.-Brilliant cherry red, a very effective color; flowers of fine form and finish, carried well upon the plant; petals of great substance; plant vigorous, hardy, and resists mildew. One of the best varieties for forcing and open air culture.

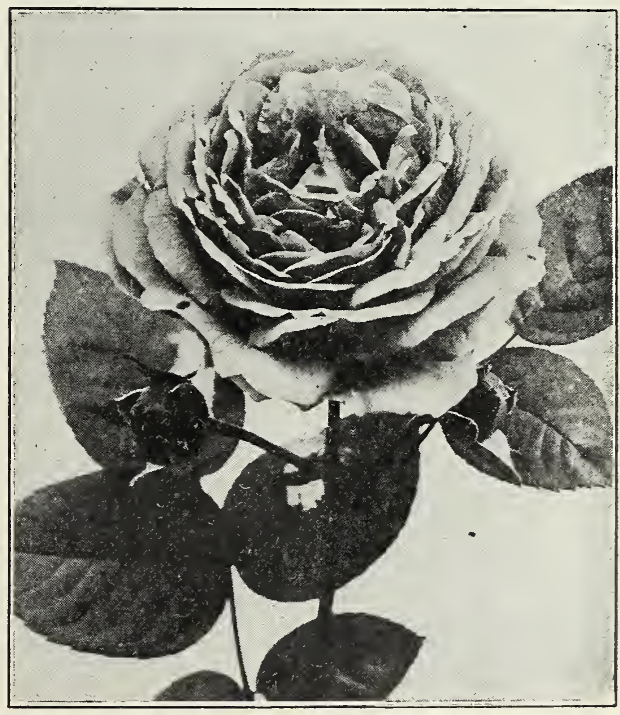

Paul Neyron 


\section{HYBRID TEAS-Half Hardy}

We Recommend Spring Planting Only

The roses included in this section are valued especialy for their free and continuous bloom. ing qualities which render them particularly useful to plant in beds and groups for the or. namentation of the lawn or to grow in the garden for a supply of cut flowers or decora. tive purposes.

Caroline Testout.-Large and double, color clear bright rose, very sweet, resembling La France, but of more sturdy habit, very free flowering; one of the best roses.

Duchess of Albany, or Red La France.-(Hybrid Tea)-Resembles the La France but is much deeper in color. Is a free bloomer, producing an abundance of lovely buds and flow. ers throughout the season. Very double and full. Color, brilliant, rose pink.

Gruss an Teplitz.-Color scarlet, shading to velvety crimson, very fragrant, a free grower and most profuse bloomer; handsome foliage, especially valuable as a bedding rose.

Killarney.-Color flesh, shaded white, suffused pale pink flowers; large buds, long and pointed; and blooms profusely throughout the season.

La France. - (Hybrid Tea) - Raised from seed of a tea rose. Delicate silvery rose, changing to silvery pink; very large; full, of fine globular form; a most constant bloomer.

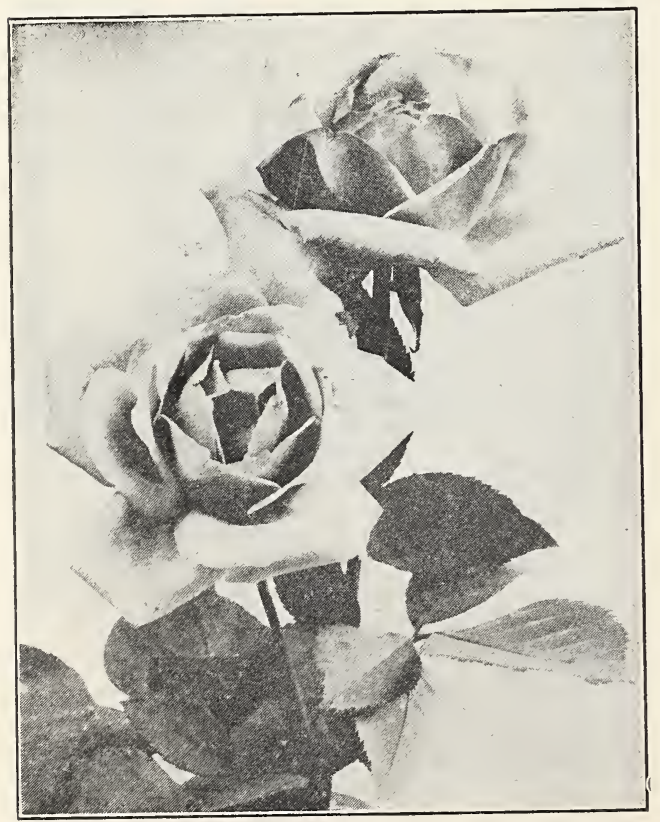

Killarney

\section{TEA ROSES}

We Recommend Spring Planting Only

Bon Silene.-Equally valuable for summer or winter blooming. Buds of beautiful form; an unusually free bloomer; color deep rose, shaded with carmine.

Catherine Mermet.-One of the finest roses grown. The buds are very large and globular, the petals being recurved and showing to advantage the lovely bright pink of the center, shading into light creamy pink, reminding one of La France in its silvery shading.

Gloire de Dijon.-Noted for its large-sized flowers, its delicate tea scent, and its exquisite shades of color, being a blending of amber, carmine and cream.

Marechal Neil.-A beautiful deep yellow; large and globular; fragrant; free flowering; one of the finest yellow tea-scented roses; a good climber.

Papa Gontier.-A magnificent red Tea. It is a strong grower, with fine healthy foliage; the buds are large and long, with thick, broad petals of dark carmine crimson color, changing to a lighter shade in the open flower.

Perle des Jardins.-A beautiful straw color, sometimes deep canary; very large, full and of fine form; stiff shoots or stems, and very free flowering.

The Rose has rightfully earned for itself the name "Queen of Flowers," and one of the most useful as well as ornamental varieties are the climbers. They are admirably adapted for covering arbors, porches, etc., and bloom profusely.

\section{HARDY CLIMBING ROSES}

Baltimore Belle.-Pale blush, nearly white, compact. A fine flower.

Blue Rambler (Veilchenblau.-(Violet Blue) -A seedling of the Crimson Rambler. The blossoms are semi-double, of medium size, massed in large numbers. The color on first unfolding is a reddish, purplish pink, turning to amethyst and finally steel blue. Plant is vigorous and hardy.

Climbing Jules Margottin.-Carmine rose, fine in open flower and in bud; the best of all climbing sorts. It may be grown either as a Pillar Rose or by pruning, kept in bush form. 


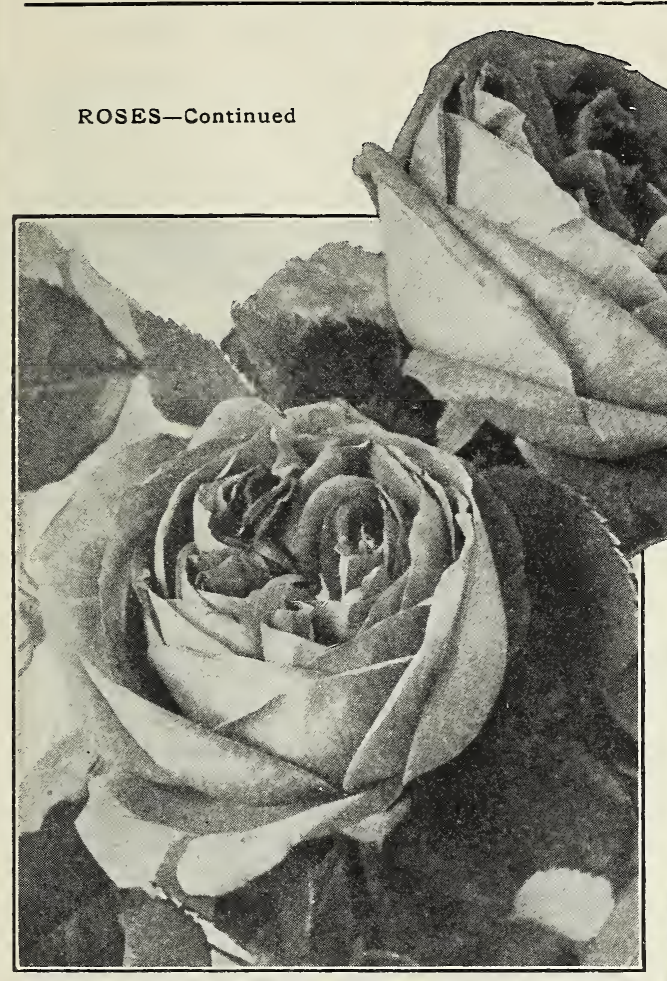

Climbing Amerian Beauty

Climbing American Beauty.-Color rosy crimson, similar to its pollen parent; flower about four inches in diameter, finely formed on long stems. Blooms very freely in May and June, and occasionally during the summer. The plant is a strong grower, making shoots ten to twelve feet in a season, and perfectly hardy. Foliage deep glossy green; does not mildew; is not subject to black spots, and remains on until frost.

Crimson Rambler.-The wonderful Japanese Rose, by far the most important and valuable acquisition of recent years. It is a climbing rose of vigorous habit, strong and rapid grower with handsome foliage, and produces in marvelous abundance clusters of the brightest crimson roses.

Climbing Victor Verdier.-Resembles Victor Verdier, of which it is a seedling, but having a decided climbing habit. Bright rose, with carmine center; a very fresh shade of color; free bloomer; wood nearly smooth. This variety is particularly desirable on account of its vigorous constitution and free flowering habit.

Dorothy Perkins.-Very large for a climber. Double, of a beautiful shell pink color; fragrant.
Flower of Fairfield.-(Ever Blooming) -From the Crimson Rambler, similar in color and more brilliant. Flowers on young wood first year. Vigorous.

Gem of the Prairie.-Carmine crimson, occasionally blotched with white; a cross hybrid between Madam Laffay and Queen of the Prairie.

Lady Gay-Beautiful rose pink; very free flowering; one of the best.

Pink Rambler.-Flowers medium size, pink in clusters. Very pretty.

Queen of the Prairie.-Bright rosy red, with white stripe.

Tausendschon, or Thousand Beauties.-Cannot be too highly recommended on account of its free flowering qualities and beautiful white and delicate pink blossoms. It has already been recognized by the leading florists, and is grown in large quantities now for winter forcing, and for garden decoration it cannot be surpassed.

White Rambler.-Small or medium, daisylike, pretty white flowers in'large clusters.

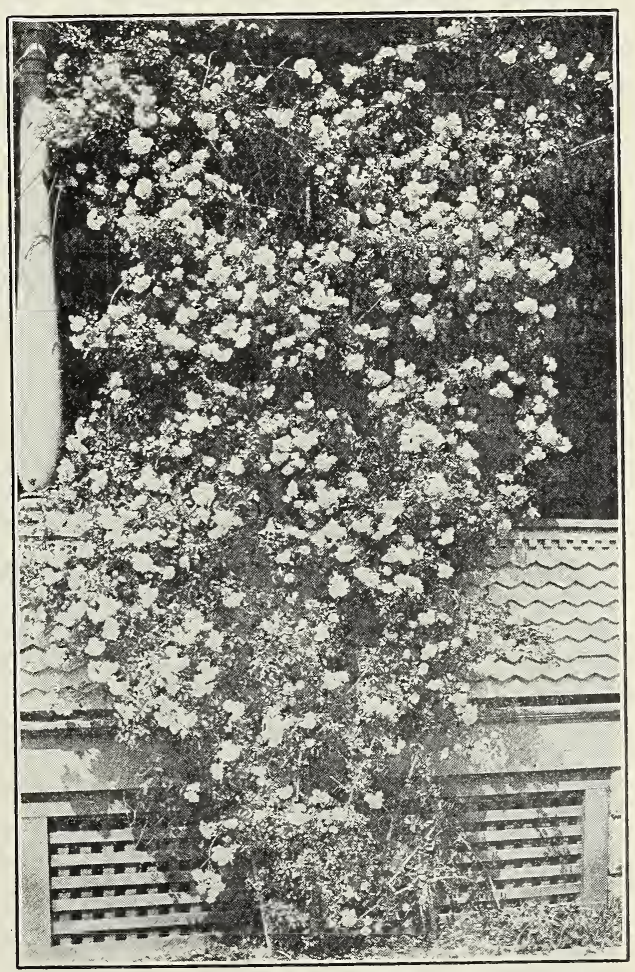

Crimson Rambler 


\section{ROSES-Continued}

Wichuriana Rubra.-Single, bright scarlet, in large clusters, with orange red stamens.

Yellow Rambler.-Yellow in bud, but white when fully open; when half open the fowers are tinged with yellow, slightly fragrant. Plant vigorous and free-blooming; hardy, very pretty and desirable.

\section{MOSS ROSES.}

The Moss Roses are favorites with every one, on account of the beautiful buds, which, for bouquets and cut flowers, are invaluable.

Blanche Moreau.-Pure white, large, full and of perfect form; the buds and flowers produced in clusters and freely furnished with a deep green moss. A valuable variety.

Blanche Robert.-Flowers pure white, large and full; buds very beautiful. A rampant grower, being almost as vigorous as a climber.

Crested.-Deep pink buds, surrounded with mossy fringe and crest; very beautiful and fragrant; growth slender.

Glory of Mosses.-A moderate grower. Flow. ers very large, appear to best advantage when full; color pale rose.

Princess Adelaide.-A vigorous grower, pale rose and of medium size and good form.

Perpetual White.-Pure white.

Salet.-A vigorous grower and perpetual bloomer. Light rose, large, full. The best of the class. A true perpetual moss, blooming at intervals from June until November.

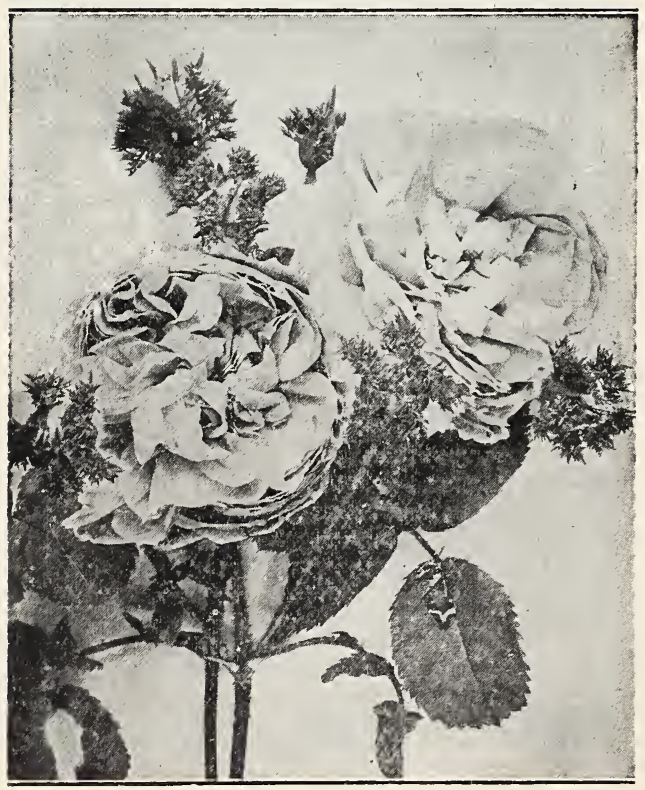

Crested Moss

\section{DWARF POLYANTHA ROSES.}

This is a novel, distinct and charming class of roses. The plant is of $d$ warf habit and bears abundantly and continuously clusters of dainty, small flowers, of perfect form and of various shades of color. While they are admirably suited to cut for bouquets and boutonnieres, they are ideal bedding roses, and supply a long felt want among rose culturists for that purpose.

Baby Dorothy. - (Maman Levavasseur) This latest introduction of the well-known raisers of the now famous Crimson Baby Rambler (Mme. Norbert Levavasseur) is similar in all respects to that variety except that the flowers are of a clear, brilliant pink and very frecly produced.

Baby Rambler Pink.-(Anny Muller)Large clusters of brilliant rose-colored flowers in great profusion. A splendid bedding variety. Blooms all season until buds are killed by severe frost.

Baby Rambler Red.-(Madame Norbert Levavasseur)-A dwarf form of the widely known and popular climbing rose, Crimson Rambler, being hardy, vigorous and perpetual flowering. The flowers are large, well formed, of a crimson red color, and borne in clusters.

Baby Rambler White--(Katherine Zeimet)Pure white in large clusters; very freely flowering.

\section{RUGOSA ROSES.}

This is a very interesting group, of Japanese origin. The flowers are mostly single. The plant is highly ornamental on account of its good habit and beautiful glossy foliage.

Madame G. Bruant.-One of the first of a new race of hybrids. Semi-double; pure white, fragrant, and produced freely in clusters at intervals throughout the summer; exceptionally hardy and vigorous.

Rugosa alba.-A species from Japan. Single, pure white flowers of five petals; highly scented.

Rugosa rubra.-Another Japan variety. Flowers single, of a most beautiful bright rosy crimson, succeeded by large berries of a rich rosy red color.

\section{TREE ROSES}

Tree Roses.-These are top grafted or budded upon strong growing wild stocks at a distance of $3 \frac{1}{2}$ to $4 \frac{1}{2}$ feet from the ground. They thus form tree shaped plants, nicely headed, and with proper care they are very desirable. We offer them in all colors. 
A

Abies

Acer

Aesculus

Age of Trees and Plants ..........

Age at which Different Trees Fruit. .

Ailanthus

Alder

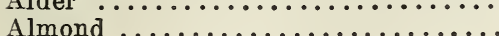

Althea

Alnus

Amygdalus $\ldots \ldots \ldots \ldots \ldots \ldots \ldots \ldots \ldots \ldots \ldots$

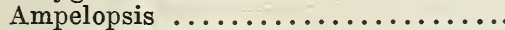

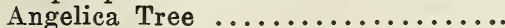

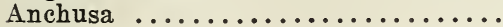

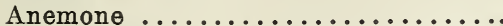

Apples $\ldots \ldots \ldots \ldots, \ddot{8}, \ddot{9}, \dot{10}, \ddot{11}, \ddot{12}, \ddot{13}, 1$

Apricot ................... 29

Aralia .................... 55

Arrow $\operatorname{Root} \ldots \ldots \ldots \ldots \ldots \ldots \ldots \ldots \ldots . \ldots \ldots$

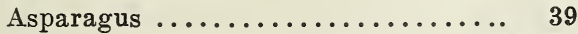

Ash ....................43, 51

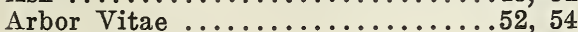

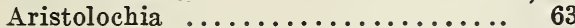

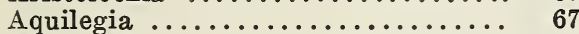

Azalea

$\mathbf{B}$

Barberry ................. 56

Berberis ......................... 56

Beech ....................43, 51

Begonia ................... 70

Betula ............................ 51

Birch ..................... 51

Birthwort $\ldots \ldots \ldots \ldots \ldots \ldots \ldots \ldots \ldots \ldots, 63$

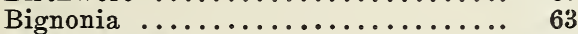

Blackberries .............. 38

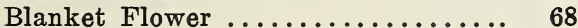

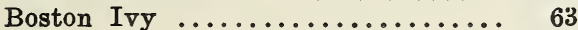

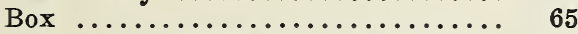

Bulb and Tuberous Rooted Plants... 70

Butterfly Bush .............55, 56

Butternut .............. 40

Buxus ........................... 65

Calla Lily .................. 71

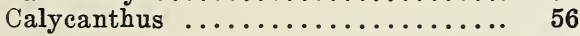

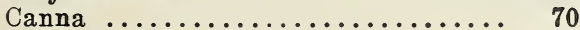

Care in Planting ................ 42

Catalpa ..................... 44

Cerasus $\ldots \ldots \ldots \ldots \ldots \ldots \ldots \ldots \ldots \ldots \ldots \ldots \ldots 44,51$

Ceris ...................... 45

Cherry ..............20, 21, 44, 51

Chrysanthemum ............. 67

Chestnut ................ 40

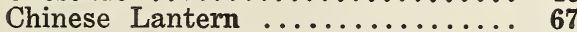

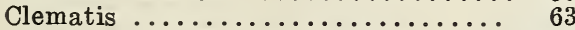

Climbing and Trailing Shrubs ..... 63

Clethra .................... 56

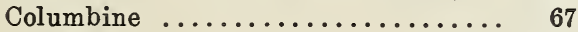

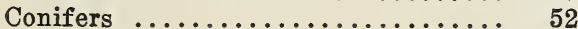

Cone Flower ................. 69

Coreopsis ......................... 67

Cornus ..................... 57

Corchorus .................. 59

Crab .................... 44

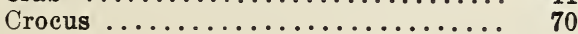

Crataegus ............... 49

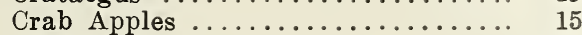

Currants .................... 34-56

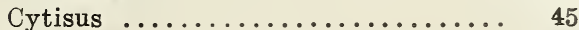

Cydonia .................... 60

$\mathrm{D}$

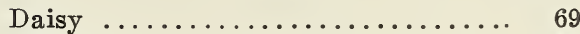

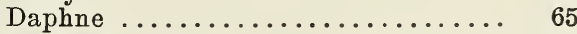

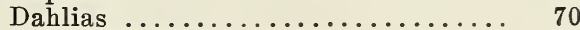

Deciduous Hedge Plants ............. 54

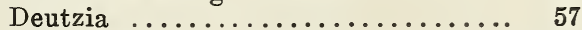

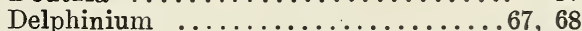

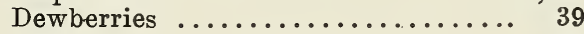

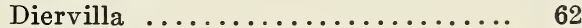

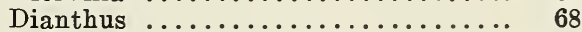

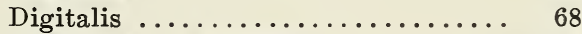

Distances for Planting .......... 4

Dogwood ..................44, 57

Dwarf Polyantha Roses ......... 78

\section{E}

$\operatorname{Elm} \ldots \ldots \ldots \ldots \ldots \ldots \ldots \ldots \ldots, 51$

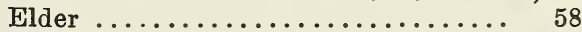

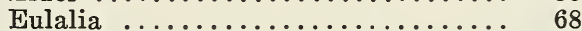

Evergreens .......................... 65

Evergreen Bitter Sweet ........ 63

Evergreen Hedge Plants .......... 54

\section{F}

Fagus .................43, 51

Fir ...................... 52

Filberts ................. 40

Flowering Trees .................. 41

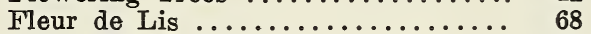

Formulas for Spraying ............. 5

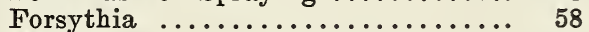

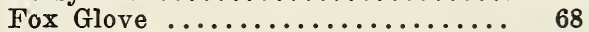

Fraximus ................. 43

Fruit Notes ................ 4

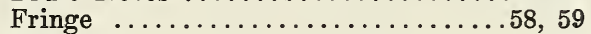

Funkia ................... 68

G

Gaillardia ..................... 68

Gladiolus .................. 70

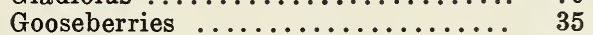

Golden Bell ................. 58

Golden Glow ................. 69

Grapes ................30, 31, 32, 33

$\mathrm{H}$

Halesia .................... 58

Hardy Climbing Roses ........76, 77, 78

Hardy Lilies ................. 71

Hemlock ......................... 52

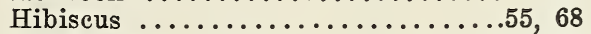

Hollyhock .................. 68

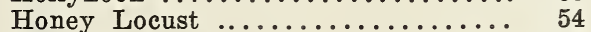

Horse Chestnut ............... 45

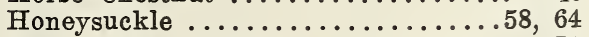

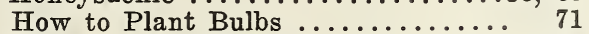

How to Grow Roses ............... 72

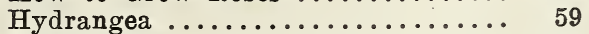

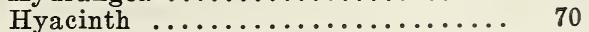

Hybrid Perpetual Roses .......73, 74, 75

Hybrid Tea Roses $. . \ldots \ldots \ldots \ldots \ldots \ldots, 76$ 
Iris

\section{J}

Japan Quince

Jonquils

Judas Tree ...

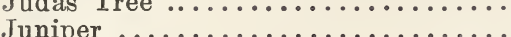

Juniperus

Juglans

\section{K}

Kalmia

Kerria

\section{L}

Laburnum

Larkspur

Larix

Larch

Linden

Lingstrum

Lilac

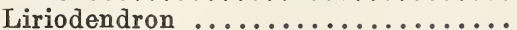

Lonicera.

.58 ,

Locust

Lycium

\section{M}

Magnolia

\section{Mahonia}

Maiden Hair Tree

Maple

Matrimony Vine

Meadow Sweet

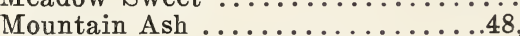

Moss Roses

Mock Orange

Mountain Laurel

Morus

Mulberr

Narcissus

Nectarines

Number of Trees and Plants to acre.

Nut Trees

\section{O}

Oak

Ornamentals

Osage Orange

\section{$\mathrm{P}$}

Paeonies

Papaver

Peaches

Pears

Persica

Philadelphus

Phlox

Pine

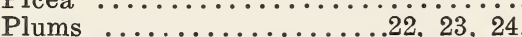

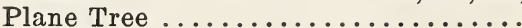

Platanus

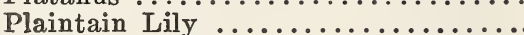

Poplar

Populus

Poppy

Prunus

Privet

Pyrus
Quercus

Quince

\section{$\mathrm{R}$}

Raspberries .................. 37

Red Hot Poker ............... 70

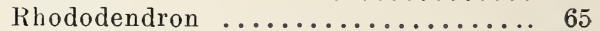

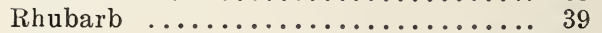

Rhus ................... 61

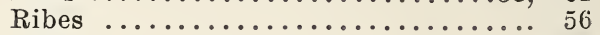

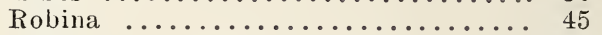

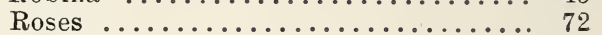

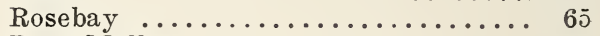

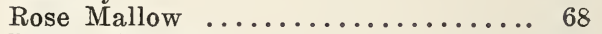

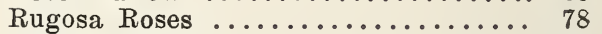

Rose of Sharon .............. 55

Rudbeckia ................. 69

\section{$\mathrm{S}$}

Salisburia ................. 49

Salix ....................50-51

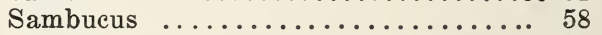

Shrubs ........................ 55

Shasta Daisy ............... 69

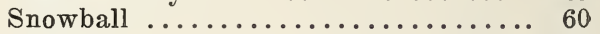

Snowberry ................. 60

Sorbus ...................48-51

Spanish Bayonet ............. 70

Spray Calendar ............... 6

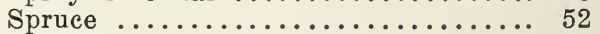

Spirea .................... 61

Strawberries ................ 40

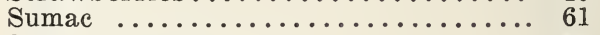

Sweet Scented Shrub ........... 56

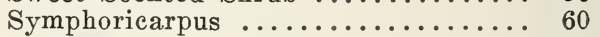

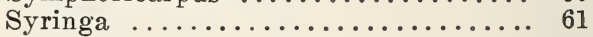

\section{$\mathrm{T}$}

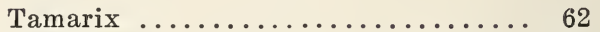

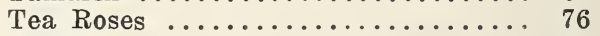

Thorn .................... 49

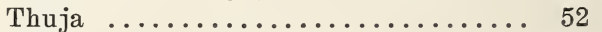

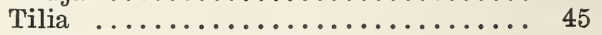

Transplanting Directions ........ 2, 3

Tree of Heaven ............... 50

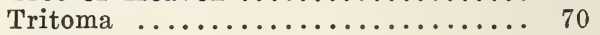

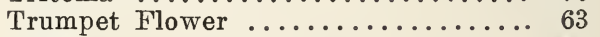

Tsuga ........................ 52

Tulip ........................ 71

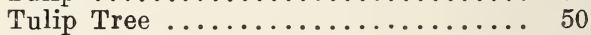

Tuberoses ..................... 71

$\mathrm{U}$

Upright Deciduous Shrubs ........ 55

Upright Deciduous Trees .......... 43

Ulmus ................... 44

Viburnum ................ 60

Walnut .................. 40

Weigela $\ldots \ldots \ldots \ldots \ldots \ldots \ldots \ldots \ldots \ldots \ldots \ldots .6 \%$

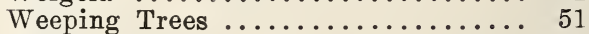

Willow ............................ 51

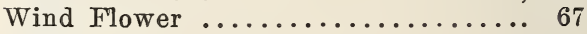

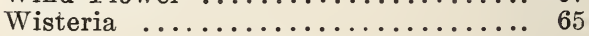

Yew $\ldots \ldots \ldots \ldots \ldots \ldots \ldots \ldots \ldots \ldots \ldots$

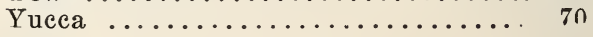




\section{Order Blank \\ BROWN BROTHERS COMPANY

Date 19

\section{Gentlemen :}

Enclosed find \$_._._._._._, for which please send me the following stock selected from your catalogue, by mail, express or freight.

Name

Street and No.

R. F. D.

Post Office

State

Express Office

Freight Station

Express Co.

Railroad

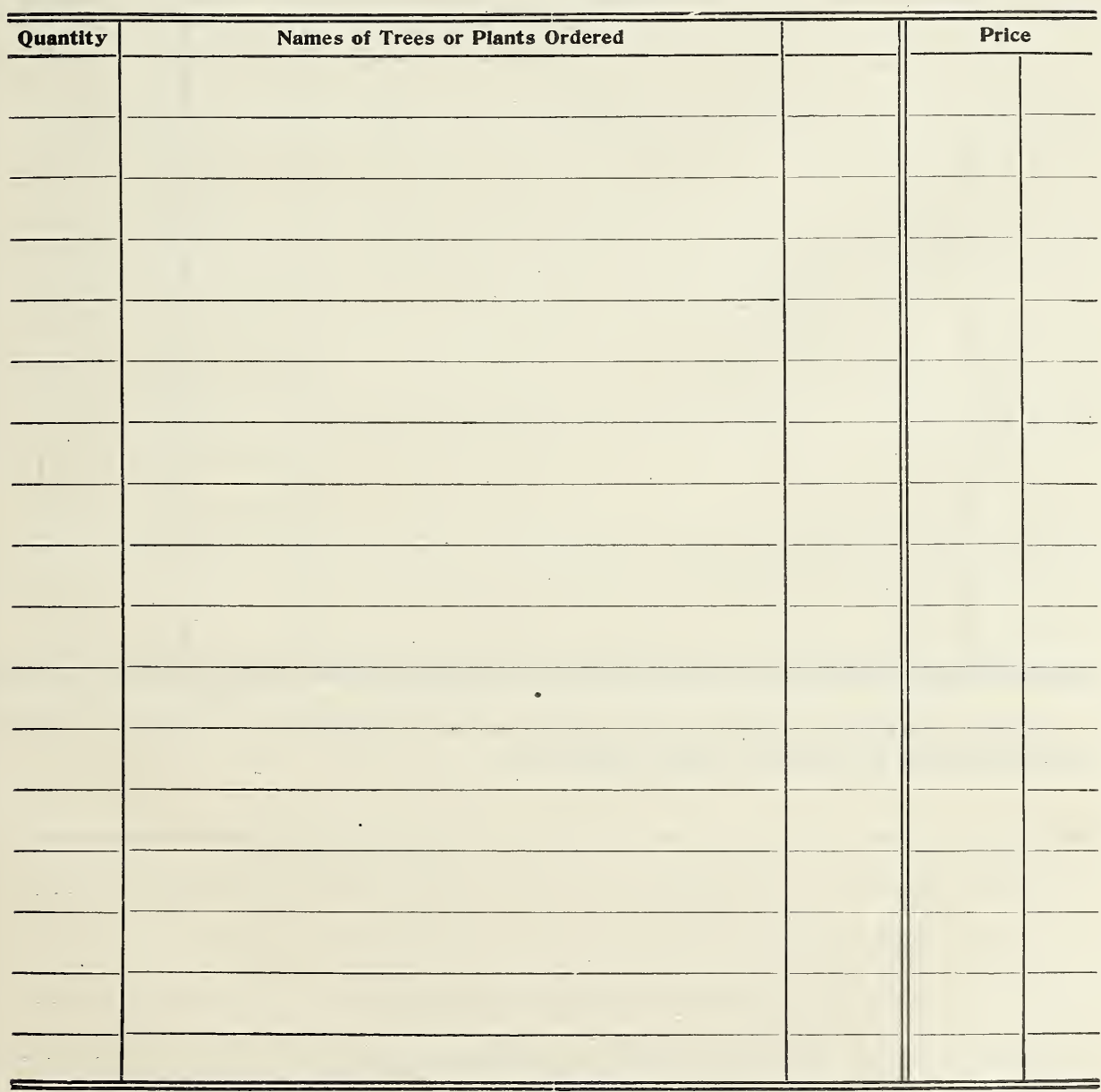

Amount carried forward. (Over) 


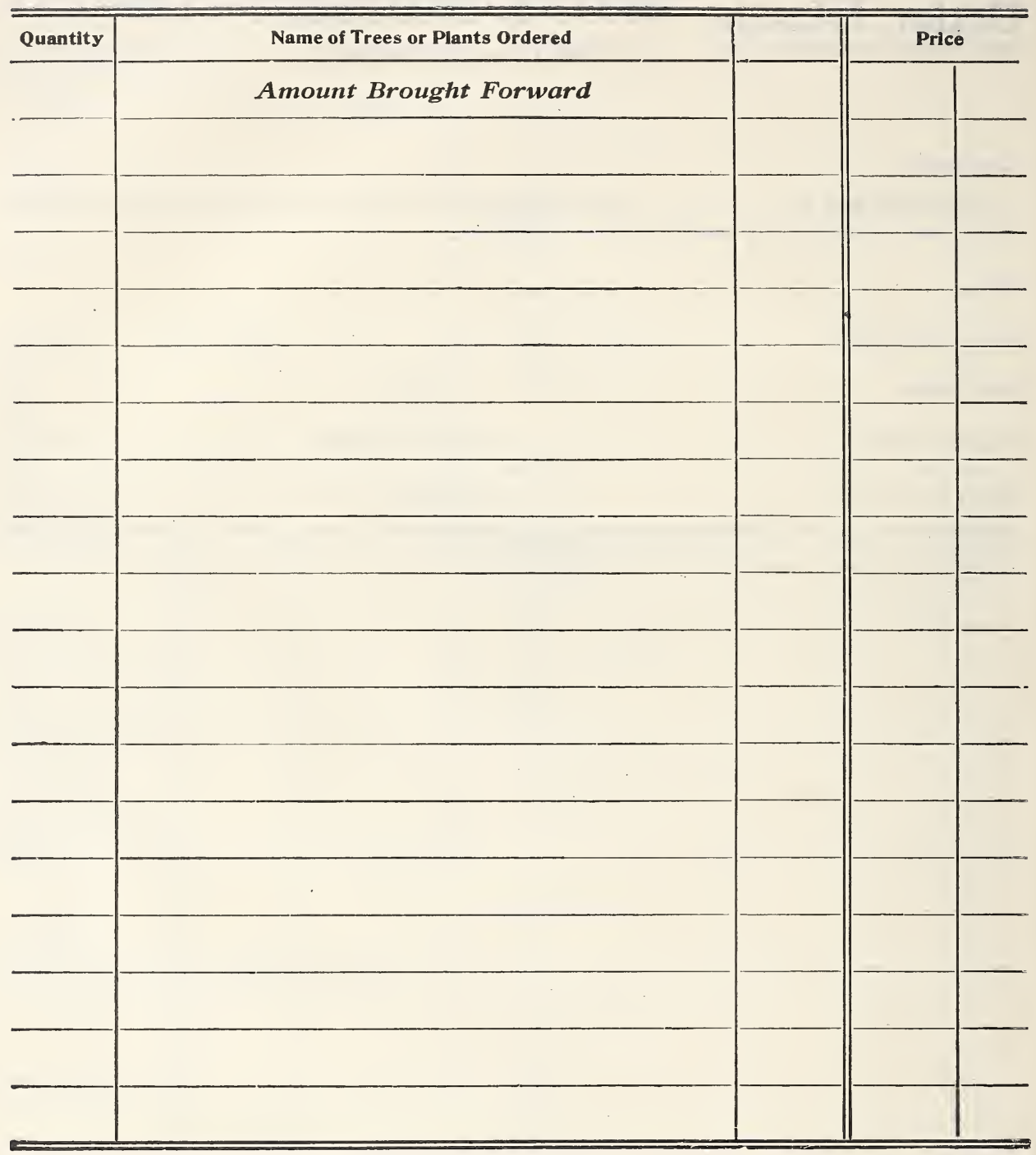

Please write below the names and address of any acquaintance or friend who might be interested in or buyers of Trees, Plants, etc. 
BROWN BROTHERS COMPANY, ROCHESTER, N. Y.

\section{MEMORANDUM}


BROWN BROTHERS COMPANY, ROCHESTER, N. Y.

MEMORANDUM 

